UNIVERSIDADE DE SÃO PAULO

ESCOLA DE COMUNICAÇÕES E ARTES

LUCAS BASTOS GUIMARÃES BAPTISTA

Realismo e formalismo como pólos de composição fílmica 
LUCAS BASTOS GUIMARÃES BAPTISTA

\section{Realismo e formalismo como pólos de composição fílmica}

Dissertação apresentada à Escola de Comunicações e Artes da Universidade de São Paulo, para obtenção do título de Mestre em Meios e Processos Audiovisuais.

Área de Concentração: Meios e Processos Audiovisuais.

Orientador: Prof. Dr. Cristian da Silva Borges.

SÃO PAULO

2014 
Autorizo a reprodução e divulgação total ou parcial deste trabalho, por qualquer meio convencional ou eletrônico, para fins de estudo e pesquisa, desde que citada a fonte.

Baptista, Lucas Bastos Guimarães

Realismo e formalismo como pólos de composição fílmica / Lucas Bastos Guimarães Baptista. - São Paulo: L. Baptista, 2014.

$240 \mathrm{p}$.

Dissertação (Mestrado) - Programa de Pós-Graduação em Meios e Processos Audiovisuais - Escola de Comunicações e Artes / Universidade de São Paulo.

Orientador: Prof. Dr. Cristian da Silva Borges.

Bibliografia

1. Estética cinematográfica - Composição 2. Realismo - André Bazin 3. Formalismo - Hollis Frampton 4. Crítica cinematográfica - Cahiers du Cinéma - Film Culture I. Borges, Cristian da Silva II. Título.

CDD 21.ed. - 791.43 


\section{FOLHA DE APROVAÇÃO}

Lucas Bastos Guimarães Baptista

Realismo e formalismo como pólos de composição fílmica

Dissertação apresentada ao Programa de Pós-Graduação em Meios e Processos Audiovisuais, para obtenção do Título de Mestre.

Área de Concentração: Meios e Processos Audiovisuais.

Linha de Pesquisa: História, Teoria e Crítica.

Orientador: Prof. Dr. Cristian da Silva Borges.

Aprovado em:

\section{Banca examinadora}

Prof. Dr.

Instituição:

Assinatura:

Prof. Dr.

Instituição:

Assinatura:

Prof. Dr.

Instituição: Assinatura: 


\section{AGRADECIMENTOS}

Ao Prof. Dr. Cristian da Silva Borges, pela confiança e incentivo, pela orientação paciente e pelas sugestões que serviram para aprimorar a metodologia e o próprio texto.

Ao Prof. Dr. Ismail Xavier e à Prof. Dra. Sônia Salzstein, pela leitura do capítulo apresentado na qualificação, na qual as observações foram fundamentais para o desenvolvimento da fase seguinte do trabalho.

À Coordenação de Aperfeiçoamento de Pessoal de Nível Superior (CAPES), pela bolsa concedida.

À Fundação de Amparo à Pesquisa do Estado de São Paulo (FAPESP), pela bolsa concedida. 


\title{
RESUMO
}

O projeto tem por objetivo o estudo da composição fílmica a partir da polarização entre realismo e formalismo. Em um primeiro momento, compreende os principais pontos definidos por André Bazin e Hollis Frampton, apresentando algumas de suas observações e críticas do que consideravam as características fundamentais do cinema. Em seguida, é proposta uma ampliação dessa comparação, num diálogo com obras e autores que de alguma maneira orbitaram em torno de Bazin e Frampton. Investigando as maneiras pelas quais as duas tendências se opõem, e quais aspectos relativos à composição são evidenciados por elas, o trabalho busca ainda uma possível complementaridade, uma abordagem que as considere igualmente como partes de um mesmo espectro.

Palavras-chave: Composição; Realismo; Formalismo; André Bazin; Hollis Frampton.

\begin{abstract}
The purpose of this project is the study of film composition by means of the polarity between realism and formalism. At first, it covers the main points defined by André Bazin and Hollis Frampton, presenting some of their insights and criticisms, and what they considered to be the fundamental qualities of cinema. From this follows an attempt to amplify the comparative outlook, in a dialogue between authors and films that were closely related to Bazin and Frampton. As the work investigate the ways by which both tendencies oppose each other, and what aspects of film composition are revealed by this opposition, it looks for an approach which considers them equally as parts of the same spectrum.
\end{abstract}

Keywords: Composition; Realism; Formalism; André Bazin; Hollis Frampton. 


\section{MITOS DE ORIGEM E DESTINO}

$\begin{array}{ll}\mathrm{O} \text { mundo à sua própria imagem } & 08\end{array}$

Uma contraparte da linguagem 12

Hemisférios 16

II. A HERANÇA FOTOGRÁFICA E O LUGAR DO CINEMA NO SISTEMA DAS ARTES

O complexo da múmia $\quad 24$

A criatura do momento 30

Entre o sujeito e o objeto 37

III. ELEMENTOS E MODOS DE ARTICULAÇÃO

A definição do cinematográfico pelo não-cinematográfico 43

I. Cinema e pintura 44

II. Cinema e teatro 46

III. Cinema e literatura 49

IV. A psicologia da narrativa $\quad 52$

A definição da subestrutura axiomática do cinema $\quad 60$

$\begin{array}{ll}\text { I. O quadro } & 60\end{array}$

$\begin{array}{ll}\text { II. A plausibilidade da ilusão fotográfica } & 61\end{array}$

III. A narrativa 63

IV. Os caminhos da metahistória 68

$\begin{array}{ll}\text { Entre a matéria e a forma } & 79\end{array}$

I. O quadro centrífugo ou metafórico 80

II. O espaço em profundidade e a materialidade da película 85

$\begin{array}{ll}\text { III. Concretização e abstração da narrativa } & 87\end{array}$

IV. O traçado das coordenadas 92 
IV. A INFLUÊNCIA DE BAZIN E OS CONTEMPORÂNEOS DE FRAMPTON

Do cinema total às propriedades da mise en scène 96

$\begin{array}{ll}\text { I. A respiração da realidade } & 98\end{array}$

$\begin{array}{ll}\text { II. A oscilação entre ordem e acaso } & 107\end{array}$

$\begin{array}{ll}\text { III. O problema da expressão } & 115\end{array}$

$\begin{array}{ll}\text { IV. O acordo entre o gesto e o espaço } & 121\end{array}$

$\begin{array}{ll}\text { O cinema de vanguarda e a mímese da consciência } & 131\end{array}$

I. A morfologia da vanguarda americana 132

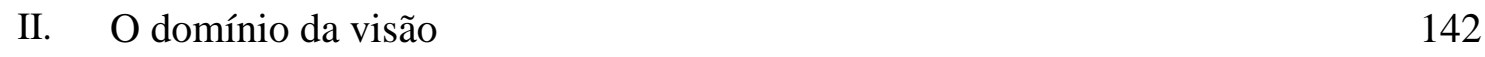

III. Variações sobre espaço e linguagem 152

IV. A ordem dos fotogramas 159

$\begin{array}{ll}\text { Meridianos } & 168\end{array}$

$\begin{array}{ll}\text { I. Diferenças internas } & 168\end{array}$

$\begin{array}{lr}\text { II. Tópicos comuns e semelhanças estruturais } & 172\end{array}$

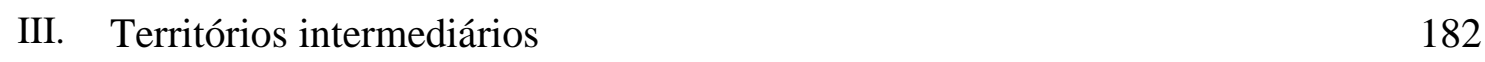

IV. As formas da realidade e a realidade das formas 199

$\begin{array}{ll}\text { CONSIDERAÇÕES FINAIS } & 206\end{array}$

$\begin{array}{ll}\text { REFERÊNCIAS BIBLIOGRÁFICAS } & 211\end{array}$

$\begin{array}{ll}\text { FILMOGRAFIA PRINCIPAL } & 220\end{array}$

ANEXOS

O mito do cinema total $\quad 224$

Film in the House of the Word 229 


\section{Introdução}

O objetivo e a estrutura desta dissertação podem ser melhor entendidos através de sua trajetória. Ela teve início como um projeto sobre o conceito de composição no cinema. Seria possível se referir à composição cinematográfica da mesma maneira que nos referimos à composição musical, pictórica ou literária - isto é, como um conjunto de práticas e efeitos passíveis de descrição por uma teoria mais ou menos integrada? Para responder esta pergunta, alguns tópicos deveriam ser abordados: qual a definição do termo, sobre quais bases ela seria feita, e qual a sua utilidade para a análise e criação no cinema. A partir desses tópicos seria organizado o corpo teórico que serviria de fundação para o trabalho.

O critério para aproximar diferentes autores seria o da comparação do cinema com outras artes nas quais encontramos um uso mais corrente do termo. O que o cinema possui em comum com a literatura, a pintura, a música? O que o cinema possui que estas artes não possuem? O que nomes tão distantes como Eisenstein e Kracauer têm a dizer sobre tais comparações? Implícita nessas considerações iniciais estava a possibilidade de que uma abordagem ampla o bastante para incluir concepções contrastantes seria capaz de contemplar, talvez de maneira coerente, descrições de obras também contrastantes, sem preferência por estilos ou gêneros específicos. Em outras palavras, uma busca pelo conceito de composição no cinema como um todo.

Entre os problemas dessa primeira etapa, o principal foi o da multiplicidade de conceitos tomados como pontos de partida pelos autores. Não apenas as teorias diferem na superfície, como suas próprias constituição e argumentação seguem caminhos por vezes completamente opostos. Para que o trabalho pudesse tomar forma, foi necessário então adotar um critério mais seletivo. A escolha recaiu sobre uma divisão já consideravelmente estabelecida na história do cinema, entre autores que tendem a uma visão "realista", e autores que tendem a uma visão "formalista" - o que, de maneira geral, significa uma preferência pela representação das imagens em movimento baseadas em sua continuidade e presença no espaço tridimensional, em oposição a uma preferência pelas articulações que permitem desenvolver relações que não necessariamente retomam essa continuidade e essa presença, priorizando a construção de um sentido estabelecido à parte dos conteúdos internos desses elementos. A 
separação em duas tendências seria, dessa forma, o próprio objeto de estudo. Não mais atacado diretamente, o conceito de composição seria considerado como por uma visão estereoscópica, na tentativa de observar o cinema por duas perspectivas, tendo ainda em mente a possibilidade de descrever um solo comum entre elas.

Mas o avanço da pesquisa revelou a necessidade de uma redução ainda maior de seu escopo. As duas vertentes, a realista e a formalista, não poderiam ser tratadas adequadamente no período de tempo previsto sem que esse tratamento tomasse um caráter excessivamente superficial. Para que isso fosse evitado, uma nova mudança: a seleção de dois autores, representantes das duas vertentes, cujo pensamento compreendesse as principais questões e que seriam comparados para enfim tratarmos de obras específicas, confrontando as intuições iniciais e as manifestações concretas dessas ideias. Uma seleção, portanto, que estaria mais apta a lidar de maneira imediata com a análise fílmica. Pela variedade de tópicos tratados, pela riqueza de observações, pelo papel que tiveram em suas respectivas tradições e pelos vários sentidos em que se distanciam em questões comuns, os dois autores escolhidos foram André Bazin e Hollis Frampton.

Bazin é certamente um dos principais nomes da teoria e crítica cinematográficas, amplamente traduzido e estudado, famoso por sua defesa da objetividade fotográfica e de estratégias que exploram o potencial realista do cinema, além da influência exercida sobre toda uma geração de autores e cineastas, especialmente àqueles ligados à revista Cahiers du Cinéma e que vieram a constituir a Nouvelle Vague. Frampton é mais conhecido como cineasta, representante do período fértil em que, nos EUA, uma série de fatores permitiu o surgimento, diálogo e divulgação de certo cinema experimental, sendo ele mesmo um dos principais nomes do que se convencionou chamar de "cinema estrutural”, em que a forma geral da composição é sua característica mais evidente. O acesso restrito aos seus filmes, como à grande parte desse cinema, se reflete em sua obra teórica: seus escritos foram editados em meados da década de 80, mas logo esgotaram e permaneceram fora de circulação até sua reedição em 2009.

A escolha dos dois autores possui então outra particularidade, elaborada apenas indiretamente no decorrer da pesquisa, mas que permanece continuamente como subtexto. Trata-se, em primeiro lugar, do confronto entre um crítico que trabalhou nas décadas de 40 e 50 (ou seja, o auge do período clássico do cinema), que tem sua obra já reconhecida e estabelecida, e um cineasta, ativo entre as décadas de 60 e 80 (o período 
em que as discussões em torno da modernidade no cinema se multiplicam), cuja obra teórica ainda necessita de certo reconhecimento. Mas trata-se também do confronto entre os pressupostos que serviram de base para grande parte da concepção francesa de cinema moderno, principalmente aquele mais voltado à narrativa e aos modos de distribuição tradicionais da indústria, e de uma concepção americana que se voltou para outra direção, para obras consideradas de vanguarda, mais afastadas da narrativa e daqueles modos de distribuição. Configura-se, portanto, de maneira mais ampla, o confronto entre uma série de outros autores, cineastas, e principalmente de filmes que serviram de apoio ou complemento tanto para Bazin como para Frampton, e que com eles e através deles moldaram as investigações de outros filmes, cineastas, autores. Além da já citada Cahiers du Cinéma, a influência de Bazin se estende também a outras revistas francesas e internacionais; da mesma forma, Frampton escreveu e foi tema de inúmeros textos em revistas americanas, entre as quais podemos citar Film Culture e Millennium Film Journal. A concentração dos envolvidos na Cinemateca Francesa e no Anthology Film Archives é outro ponto de comparação, assim como a importância central das noções de autoria e independência criativa como parte da prática dos críticos e cineastas.

O conceito de composição permanece, então, como pano de fundo, assim como as vertentes realista e formalista. As questões relacionadas a esses temas (como as relações entre o cinema e outras artes) serão tratadas através do pensamento de Bazin e Frampton, de suas preferências e do contexto em que ambos estavam inseridos. Os objetos de análise serão tanto os textos como os filmes sobre os quais teceram algum comentário ou com os quais tiveram qualquer proximidade.

A dissertação se divide em quatro capítulos, ordenados segundo o mesmo movimento descrito nesta introdução, que foi o percurso pelo qual o tema encontrou uma definição gradual: a passagem das concepções teóricas mais gerais e abstratas às manifestações específicas, concretas, das obras fílmicas. Começaremos com a apresentação dos ideais de cinema dos dois autores, os "mitos" que por eles foram propostos e o papel que tomaram no corpo de suas obras: o mito de um cinema total, por Bazin, e de uma contraparte universal da linguagem, por Frampton. Retomando autores de períodos anteriores, poderemos identificar a inserção desses ideais nas duas tendências consideradas, bem como a recorrência de certas aspirações que definem grande parte das preocupações desenvolvidas em outros momentos. Em seguida, 
veremos como esses ideais se relacionam com as primeiras observações históricas, no que podemos chamar de uma ontologia (tomando o termo no sentido usado por Bazin) e genealogia do cinema: o questionamento sobre a consistência da imagem fílmica, e do lugar do cinema no sistema das artes, expondo as diferentes referências às quais Bazin e Frampton recorreram, e com as quais parecem igualmente dialogar. Passaremos então às definições do que ambos entenderam como os elementos fundamentais do cinema, as ferramentas e categorias composicionais das quais os cineastas dispõem para executar suas obras; e então às próprias obras, através de algumas das interpretações descritas por eles. Esta ordem é crucial pelo caráter construtivo descrito anteriormente, pois coloca em jogo primeiramente os pressupostos para apenas mais tarde entrar em contato com as análises locais.

O quarto capítulo se afasta dos dois autores principais, funcionando como um aumento da área de alcance acompanhado por uma diminuição de foco, para tratar de nomes que orbitaram ao redor de Bazin e Frampton, seja como aprendizes, colaboradores ou que simplesmente possuem alguma identificação e proximidade com suas ideias. Como complementos a Bazin, serão considerados Éric Rohmer, Jacques Rivette, Alexandre Astruc e Michel Mourlet; em relação a Frampton, P. Adams Sitney, Stan Brakhage, Michael Snow e Peter Kubelka. Novamente o cruzamento de duas tradições, entre críticos e cineastas, entre ideias e filmes - levando em conta, acima de tudo, as possibilidades de acréscimo e diálogo com Bazin e Frampton. Passaremos por algumas das expansões ou ramificações das questões tratadas nos capítulos anteriores, até a análise de filmes que foram atravessados por esses tópicos, seja como resultado de um pensamento desenvolvido conscientemente pelos próprios cineastas ou como objetos de críticos que os tomaram como ponto de partida para desenvolver seu pensamento. Outros nomes, entre os quais podemos citar Sergei Eisenstein, Jean Mitry, Noel Burch e Jacques Aumont, serão utilizados como referências adicionais, por vezes mais próximos de um ou outro lado, e que podem facilitar essas aproximações. Bazin e Frampton ainda estarão presentes, mas como a base que servirá a esta coordenação; os resultados dos três primeiros capítulos servirão como a grade de referências para melhor posicionarmos os autores do quarto capítulo.

A estrutura da dissertação é constante não apenas no direcionamento geral, mas também em sua divisão interna. Cada capítulo possui a mesma forma triangular: as primeiras seções apresentam a visão de Bazin e da vertente realista; as segundas 
apresentam a visão de Frampton e de seus autores correspondentes; as terceiras propõem uma síntese parcial das duas anteriores, evidenciando quais aspectos podem ser aproximados, quais permanecem em tensão, e em qual chave será feita a passagem para o capítulo seguinte. Nesse processo serão percebidas, além das já esperadas diferenças, algumas semelhanças que podem parecer surpreendentes em certos momentos, desde a estrutura do pensamento, os tópicos de interesse, e até mesmo detalhes da própria expressão dos autores - como, por exemplo, o gosto de Bazin e Frampton por metáforas científicas, e o fato de Bazin preferir as ciências naturais enquanto Frampton prefere a matemática, o que em si é algo revelador de suas posturas; ou então a coincidência das descrições de Mourlet e Kubelka, ou Rohmer e Brakhage, para algumas de suas exigências na composição.

Mais do que questionar o que os dois lados têm a dizer sobre um mesmo tópico, devemos nos questionar ainda o que um dos lados tem a dizer sobre o outro, o que pode acrescentar ao outro, e vice-versa. O fato de a comunicação entre essas partes ter sido rara coloca a necessidade de uma busca pelos poucos pontos de contato já existentes, e, além disso, que o trabalho de seleção e descrição de exemplos constitua a própria forma desse diálogo. Nos poucos casos em que ambos os lados se referem aos mesmos filmes e cineastas, significa que temos um objeto especial, sobre o qual podemos tentar projetar simultaneamente as duas perspectivas; nos casos em que apenas um dos lados se debruça sobre um filme ou cineasta, nos resta apresentar essa interpretação e considerar a outra com base no que já foi estipulado; e nos casos em que nenhum dos dois lados se entregou à análise, devemos eleger um filme ou cineasta a ser tratado como um experimento em que uma nova interpretação deve surgir da reação entre a matéria fílmica e as teorias anteriores. Ainda que não seja atingido, um certo equilíbrio entre as três possibilidades parece desejável numa pesquisa deste tipo.

Por fim, dois pontos devem ser esclarecidos. O primeiro é uma escolha consciente; o segundo é uma decorrência do contexto.

Em primeiro lugar, foi considerado durante toda a dissertação o princípio descrito por Northrop Frye na introdução de sua Anatomia da Crítica, de que o campo a ser investigado não é um mero conjunto de obras - manifestações isoladas, sucessivas e dispersas numa área cultural comum - mas um campo de conhecimento a ser organizado, e cuja ordem deve ser analisada. Este é um postulado de coerência que determina a unidade do cinema, bem como a possibilidade de identificação e 
classificação de diferentes áreas de seu espectro. Também determina que nem as teorias e nem os filmes possuem prioridade uns sobre os outros: a intuição inicial sobre a composição, assim como todas as ideias aqui descritas, só poderiam ter surgido a partir e através de evidências fílmicas, e a elas retornam constantemente, mas uma teoria possui autonomia, portanto pode e deve ser estudada diretamente.

Em segundo lugar, a dissertação também considera - porque seus objetos assim o fizeram - que o campo do cinema é constituído por áreas que compartilham uma mesma configuração material, em que as obras fílmicas são apresentadas em espaços especificamente construídos para sua projeção. É central a importância do material utilizado na composição, e o material utilizado nas composições aqui descritas é a película projetada numa sala mais ou menos padronizada. Isto significa que obras em vídeo e modos de apresentação alternativos foram vistos como fora de nosso alcance, mesmo que possam eventualmente ampliar ou se aproximar das questões tratadas. 
I.

MITOS DE ORIGEM E DESTINO 


\section{O mundo à sua própria imagem}

Em 1946, André Bazin publica um de seus textos mais célebres, "O mito do cinema total". ${ }^{1}$ Nele, Bazin defende que o surgimento do cinema não deve ser explicado pelas descobertas técnicas que o precederam, pois "o cinema é um fenômeno idealista". Ele nota um atraso entre as condições que possibilitaram o desenvolvimento do aparato cinematográfico e sua aparição efetiva: ainda que na Antiguidade houvesse um cenário favorável à realização do fenacistiscópio ou do zootrópio, vários séculos foram necessários para que tais objetos encontrassem a luz do dia. Não apenas o espírito técnico estava à altura do projeto como também o conhecimento dos fenômenos envolvidos. A persistência retiniana, por exemplo, era conhecida de longa data.

É a convergência de interesses das ciências pela síntese do movimento e a fixação automática da imagem que impressiona Bazin, e que o leva a postular o mito que dá título ao ensaio. Os pais do cinema, ele argumenta, foram industriais engenhosos perseguindo uma ideia fixa. A busca por esta idéia, "materialmente intransponível", seria revelada nos escritos de Lumière, Edison e Marey como a representação total e integral da realidade através da restituição de uma ilusão do mundo exterior, pela cor, som e relevo. ${ }^{2}$

O mito diretor da invenção do cinema é, portanto, a realização daquele que domina confusamente todas as técnicas de reprodução mecânica da realidade que apareceram no século XIX, da fotografia ao fonógrafo. É o mito do realismo integral, de uma recriação do mundo à sua imagem, uma imagem sobre a qual não pesaria a hipoteca da liberdade de interpretação do artista, nem a irreversibilidade do tempo. Se em sua origem o cinema não teve todos os atributos do cinema total de amanhã, foi, portanto, a contragosto e, unicamente, porque suas fadas madrinhas eram tecnicamente impotentes para dotá-lo de tais atributos, embora fosse o que desejassem. ${ }^{3}$

Uma reprodução integral do texto se encontra na seção de anexos da dissertação.

2 André Bazin, "O mito do cinema total", in $O$ Que é o Cinema? (São Paulo: Cosac Naify, 2014), pp. 35-37.

$3 \quad$ Ibid., p. 39. 
O ponto de partida para essa reflexão é a concepção histórica de Georges Sadoul, uma visão fundamentalmente marxista em que a causalidade da história vai da infraestrutura econômica às superestruturas ideológicas. A interpretação de Bazin funciona como uma inversão deste ponto de vista, afirmando a vocação mimética do cinema não por um confronto direto com as camadas da historiografia, mas com o que estaria $s o b$ elas, a ideia dos inventores. ${ }^{4}$

Um dos traços do mito é a relação de identidade quase metafísica estabelecida entre o cinema e a realidade. Ao interpretar a posição de Sadoul, Bazin propõe o que seria a essência do cinema - não apenas como tecnologia, mas como um empreendimento em escala mais vasta e profunda; quase poderíamos dizer como um sonho coletivo, a manifestação de parte do inconsciente da humanidade. É nessa formulação que Tom Gunning reconhece a face idealista do mito, da qual resultaria a problemática de lidar conceitualmente com algo que, em última instância, é caracterizado justamente por exceder o conceito. ${ }^{5}$

Gunning também enfatiza o que acredita ser o objetivo de qualquer leitura de Bazin: a definição do realismo cinematográfico. Sobre a distinção feita no ensaio "Ontologia da imagem fotográfica", entre o verdadeiro realismo - "a necessidade de dar expressão significativa ao mundo tanto concretamente como em sua essência" - e o pseudo-realismo "de uma ilusão direcionada a enganar o olho", ele questiona se

a obsessão com o cinema total que assombrou seus inventores excedeu o pseudo-realismo, e em que maneira se atinge o que se chama verdadeiro realismo? A resposta mais provável seria que o cinema total compartilha ambos os aspectos e que o desafio do cinema como arte não está em expressar a subjetividade individual ou em apenas reproduzir os traços do movimento, cor, som e relevo como componentes da ilusão, mas em apresentar o mundo em sua própria imagem, uma tarefa que deve ser mais elusiva do que pode parecer à primeira vista. ${ }^{6}$

Cf. Ibid., p. 35.

Cf. Tom Gunning, "The World in its Own Image”, in Dudley Andrew (ed.), Opening Bazin (Nova York: Oxford University Press, 2011), p. 120. Gunning deixa claro que não tem intenção de posicionar Bazin em um quadro filosófico mais amplo, e sim de definir alguns aspectos do idealismo no mito do cinema total. (Todas as traduções são nossas, exceto quando indicado.)

6 Ibid. 
A disposição puramente sensorial evocada por pesquisas ligadas à noção de “imersão" é, para Gunning, o que Bazin associa ao pseudo-realismo. A impotência técnica deriva da ausência de certos atributos, mas o sentido do mito reside no fato deste representar o realismo integral. O ponto central está menos na representação do movimento, ou na aparência verossímil da imagem, que na possibilidade de unificação destes aspectos, cada um deles tomado como um problema a ser resolvido - não pelo desenvolvimento "superficial", ilusório, mas na medida em que podem ser integrados. Haveria, dessa forma, uma espécie de princípio coordenador, manifesto não através de cada propriedade, mas subjacente a todas elas.

Uma interpretação para a necessidade desse princípio pode ser feita através de algumas das influências de Bazin, que são visíveis em parte de sua obra. Sua proximidade com o Personalismo e o Catolicismo, por exemplo, especialmente através de sua colaboração com a revista Esprit, ou ainda a comparação recorrente de sua devoção ao mundo natural com a de São Francisco de Assis: a crença no fator que promove a organicidade do real, que permite ao homem encarar o mistério da expressão e as motivações de sua trajetória em seu contexto inalterado, na própria descoberta da natureza. ${ }^{7}$ Para que o cinema possa representar a realidade de maneira íntegra, esta realidade deve em primeiro lugar ter sua integridade pressuposta. ${ }^{8}$

O caráter mítico é o que encontramos a cada tentativa de questionar a transposição material dessas ideias. É o que dificulta qualquer análise mais pronunciada das características que Bazin imagina serem possíveis, ou mesmo inevitáveis, nas obras que resultariam desse cenário. A impossibilidade técnica está inscrita na própria formulação do mito, que diz respeito à potência global, fundamental, mas revelada indiretamente. Podemos apenas conjecturar o que seria de fato a experiência de um filme baseado na unidade do mundo através de uma tecnologia. Entregue à representação absoluta da realidade, o espectador do cinema total seria talvez o inverso do prisioneiro da caverna platônica: encarando a imagem do mundo, consciente de sua condição de simulacro, ele reencontra uma unidade primordial através de sua reconstrução.

7 Ver o prefácio e a introdução de Hugh Gray (ed.), What is Cinema? vol. II (University of California Press, 2005). Ver também Dudley Andrew, André Bazin (Nova York: Oxford University Press, 2013).

8 É interessante sobre este ponto o comentário de Brian Henderson, para quem Bazin possui, mais do que uma estética, uma teoria do real. Ver "Two Types of Film Theory", in Film Quarterly, vol. 24, no 3, primavera de 1971, p. 40. 
Mas há uma dimensão prática no pensamento de Bazin. Ainda que possamos reconhecer uma área inacessível à análise direta, não se nega completamente o processo histórico e o encontro com obras concretas. O que Bazin enxerga na história é precisamente a superfície que cobre os movimentos internos do mito, como vemos em seus ensaios sobre a evolução da linguagem cinematográfica. O mito não postula um ponto final; ele é o motor da trajetória. As limitações técnicas não são meros obstáculos no caminho a ser trilhado; elas são, antes, a própria matéria que, frente à erosão, se molda conforme as condições atmosféricas. A progressão do cinema teria um caráter assintótico: não um simples curso de realização da visão inicial, mas uma constante nunca inteiramente satisfeita; um projeto dialético, absorvendo suas técnicas e as transcendendo sem nunca atingir seu fim. O cinema total é para Bazin o horizonte do cinema, seu limite fenomenológico, em natural expansão. ${ }^{9}$

9 Cf. Gunning, Op. cit., p. 124. 


\section{Uma contraparte da linguagem}

Em 1981, Hollis Frampton publica "Film in the House of the Word", um ensaio que aponta para uma direção diferente daquela elaborada por Bazin, mas que adota características semelhantes em seu percurso.

O texto começa com a lembrança de um manifesto de Eisenstein em que a defesa da montagem como princípio da composição fílmica é acompanhada pela recusa da sincronia entre som e imagem. O surgimento do som, segundo Eisenstein, possibilitaria uma série de avanços. $\mathrm{O}$ uso de intertítulos e closes explicativos, visto como um passo em direção ao desequilíbrio entre obra e espectador, se tornaria desnecessário. Livre para perseguir o aspecto dialético no método, o cineasta passaria sem tais "erros formalistas", e a montagem teria sua "capacidade termodinâmica" desenvolvida pela inclusão do novo elemento. Para tanto, seria essencial que a relação entre som e imagem fosse assincrônica: a adesão do som à imagem apenas contribuiria para sua inércia e independência de significado. A restrição dos movimentos dos atores e o foco no roteiro e nos diálogos como bases da realização no início do cinema sonoro apenas atestam esse ponto de vista.

Mas o projeto da montagem intelectual e a esperança do som como elemento de contraponto à imagem teriam sido abandonados por Eisenstein em prol de pesquisas voltadas à fusão das artes e à articulação cênica dos signos, como no drama musical de Wagner. Frampton identifica nos argumentos de Eisenstein uma relutância não em relação ao som propriamente dito - não uma simples negação da dimensão sonora cujo potencial seria subestimado pela sincronia -, mas à linguagem, "a decodificação linear do terreno do pensamento em um fluxo de discurso". ${ }^{10}$

Ele então chama atenção para o que imagina que Eisenstein estaria tentando proteger da linguagem:

algo a cujas partes deve ser negado - e das quais deve-se proteger de interdependência e adesão mútua; que não deve ser sobrecarregado, nem ter sua

10 Hollis Frampton, "Film in the House of the Word", in Bruce Jenkins (ed.), On the Camera Arts and Consecutive Matters: The Writings of Hollis Frampton (Cambridge e Londres: The MIT Press, 2009), p. 168. Originalmente em October, $\mathrm{n}^{\circ}$ 17, verão de 1981. Uma reprodução integral do texto se encontra na seção de anexos da dissertação. 
inércia elevada, ou seu tempo diminuído; que deve permanecer portátil através de fronteiras culturais, e cuja elaboração e desenvolvimento não devem ser impedidos. $^{11}$

Frampton diz que apenas dois sistemas satisfazem essas condições: uma linguagem universal e uma máquina perfeita. E completa:

É possível sugerir que [Eisenstein] vislumbrou, não importa quão brevemente, um projeto além da montagem intelectual: a construção de uma máquina, muito próxima do cinema, mais eficiente que a linguagem, que poderia, entrando em competição direta com a linguagem, transcender sua velocidade, abstração, compacidade, democracia, ambiguidade, poder... um projeto, além de tudo, cuja última promessa seria a constituição de uma crítica externa da própria linguagem. Se tal coisa viesse a existir, a mecânica celeste do intelecto consequentemente poderia visualizar um corpo chamado Linguagem e um corpo chamado Cinema, em órbita simétrica, um ao redor do outro, em movimento perpétuo e dialético. ${ }^{12}$

Assim como Bazin, Frampton propõe uma espécie de mito que projeta, de uma só vez, um passado ao qual a atenção deve se voltar para compreender uma função do cinema, e um futuro que parece atrair esta função. E também como em Bazin, o caráter dessa projeção é posto em evidência através de uma especulação com ares metafísicos.

Frampton cita um ensaio de Jorge Luis Borges sobre o sonho de Coleridge que teria dado origem ao poema "Xanadu". Segundo Borges, Coleridge sonhou com o poema, e, ao acordar, dedicou-se à sua concepção a partir de lembranças esparsas da obra experimentada oniricamente. Frampton chama atenção para a reflexão que encerra o ensaio, de que algumas ideias, "arquétipos ainda não revelados aos homens", talvez se esforcem para ganhar vida, sendo constituídas através de uma série de eventos no decorrer dos séculos, até que, "quando tivermos alterado nossas formas de raciocínio e reservado nossos sonhos para assuntos menos técnicos", elas possam ganhar seu lugar no mundo. Ele retorna então à sua hipótese ao dizer que, no futuro próximo, o cinema, a fotografia e o vídeo seriam vistos eventualmente não como uma série de coisas 
separadas, mas "partes de algo, ou tentativas, ao mesmo tempo completas e aproximadas, de se construir algo que será equivalente a uma área do pensamento... comensurável com aquela da linguagem". ${ }^{13}$

A área comensurável com a da linguagem, que a excede em universalidade e articula o pensamento de maneira ainda mais compacta, ambígua e abstrata: este é um projeto conhecido na história do racionalismo filosófico. Encontramos, por exemplo, na exigência cartesiana de uma lingua universalis, descrita por Ernst Cassirer como análoga ao projeto de matematização da natureza (mathesis universalis): "assim como existe uma ordem perfeitamente determinada entre as ideias da matemática... da mesma forma o todo da consciência humana, juntamente com todos os conteúdos que nela se possam integrar, formam um conjunto rigorosamente ordenado". ${ }^{14}$

A ligação de Frampton com a linguagem é facilmente rastreada em sua formação. ${ }^{15}$ Seu interesse pelas artes se inicia com a poesia, à qual se dedica por um período no qual troca correspondências com Ezra Pound e eventualmente se torna um de seus visitantes em Nova York. A veia modernista de Pound e a composição expansiva e multilíngue dos Cantos servem de modelos para Frampton até o final de sua vida, sendo comentadas por ele em diversas ocasiões. O gosto pela música serial e a matemática acrescentam ainda a dimensão sistemática e abstrata que se tornou característica de seus filmes, a tendência a buscar princípios geradores, lógicos e autoreferentes. O papel central da fotografia em sua formação completa essas disposições; veremos mais à frente como sua passagem da fotografia para o cinema se dá inevitavelmente pelo filtro linguístico, bem como pela aspiração à universalidade da matemática.

A descrição de Frampton possui a mesma característica identificada por Gunning sobre o mito do cinema total: a especulação além do conceito, direcionada para o que seria a essência da arte, intuída a partir de um de seus aspectos, manifestos incompletamente e projetados no futuro como possibilidade. $\mathrm{O}$ foco, invertido, não se volta mais para a capacidade mimética do cinema e sua relação de identidade com a

13 Frampton, "The Invention without a Future", in Jenkins, Op. cit., pp. 179-180. Originalmente em October, $\mathrm{n}^{\circ} 109$, verão de 2004.

14 Ernst Cassirer, A Filosofia das Formas Simbólicas - A Linguagem (São Paulo: Martins Fontes, 2009), pp. 96-104.

15 Para uma exposição autobiográfica de Frampton, ver sua entrevista a Robert Gardner no programa Screening Room (1977). Para outros relatos, ver Annette Michelson, "Poesis/Mathesis", e Barry Goldensohn, "Memoir of Hollis Frampton", in October, n' 32, primavera de 1985, respectivamente pp. 4-6 e pp. 7-16. 
realidade, mas para como o cinema, como tecnologia, pode realizar a articulação de conteúdos além das fronteiras linguísticas.

Não mais, portanto, o mundo à sua própria imagem. Não mais a imagem livre da interpretação do artista, e cujo peso ontológico excederia a mera reprodução sensorial. O futuro do cinema imaginado por Frampton é uma encarnação maquinal da linguagem, o meio de expressão por excelência. Se o cinema total de Bazin coloca o artista frente à representação do mundo por seus próprios meios, a linguagem universal de Frampton coloca o artista frente ao "alfabeto do pensamento", à realização da escrita hieroglífica de Vachel Lindsay em uma escala ainda mais ampla. ${ }^{16}$ Se o espectador do cinema total contemplaria, a partir de sua própria ausência, a presença do mundo como unidade integrada, o espectador da máquina perfeita de Frampton entraria em contato com uma articulação verdadeiramente universal, e a tomada de controle, também através de uma representação integrada, do que ele chamou de "nossa metáfora suprema": a consciência.

16 Cf. Vachel Lindsay, The Art of the Moving Picture (Nova York: Modern Library, 2000), cap. XIII. Lindsay traça a evolução da linguagem através de padrões visuais, desde as inscrições dos egípcios e fenícios até a abstração desses padrões no alfabeto grego e no alfabeto romano. Ele interpreta algumas formas e imagens como possuindo conteúdos recorrentes, e defende que sua utilização no cinema seria uma maneira de elevar seu potencial expressivo. 


\section{Hemisférios}

A defesa de um ideal cinematográfico, que revelaria o verdadeiro propósito ou a máxima validade da arte, não é exclusiva a Bazin e Frampton. Ambos são convencionalmente identificados como partes de duas linhagens ou tradições que remontam aos primeiros pensadores do cinema, nos quais encontramos preocupações semelhantes.

$\mathrm{Na}$ análise comparada de alguns desses pensadores, Noel Carroll e Dudley Andrew concordam sobre as características gerais dessas duas tradições. Andrew compara os autores através de quatro categorias, que encara como perguntas feitas a eles: matéria-prima (perguntas feitas sobre o meio, sua relação com a realidade e uso de espaço e tempo); métodos (o processo criativo); formas e modelos (os tipos de filmes que podem ser feitos); objetivo (o valor ou significado da arte). Com isso, agrupa as teorias em vertentes que denomina formativa (representada por Rudolf Arnheim, Sergei Eisenstein, Bela Balázs) e realista (representada por Siegfried Kracauer e André Bazin). ${ }^{17}$

Para os realistas, o registro fotográfico é enfatizado positivamente como o traçado da luz perante a câmera, a marca da realidade a ser representada por planos contínuos e o mínimo de interferência ou articulação. Kracauer, por exemplo, considera a matéria-prima do cinema o próprio mundo visível, através de seu "vínculo fotográfico com a realidade". A penetração de técnicas que interfiram na apresentação dessa realidade seria o que ele chama de "formalismo", uma disposição oposta ao realismo, que, como Kracauer diz, deve predominar. ${ }^{18}$

Os autores formativos, em termos gerais, defendem um cinema que manipula e reconstitui o real, exaltando seus aspectos considerados expressivos. Eisenstein defende em certo momento a "destruição do realismo", a decomposição das aparências para que possam ser reconstruídas de acordo com um "princípio de realidade" advindo de relações estabelecidas pelo cineasta. A criação cinematográfica surgiria quando "células independentes recebem um princípio de animação". A montagem é tida como a

\footnotetext{
17 Ver a introdução de Dudley Andrew, As Principais Teorias do Cinema (Rio de Janeiro: Jorge Zahar, 2002), e Noel Carroll, Mystifying Movies (Nova York: Columbia University Press, 1988), pp. 106111. A expressão "formativa" é de Andrew; Carroll se refere à mesma tradição como "criacionista".

18 Andrew, Op. cit., pp. 94-98.
} 
principal operação, capaz de superar o registro contínuo, considerado uma mera superficialidade. ${ }^{19}$

Com base nessas características, podemos perceber, na descrição de Ismail Xavier para as tendências idealistas dos primeiros teóricos, uma oposição semelhante àquela entre Bazin e Frampton nas propostas de Germaine Dulac e Dziga Vertov.

Partindo da noção de que o substrato fotográfico do cinema possui uma objetividade essencial em relação ao que é representado - e, portanto, concordando em parte com os realistas -, Dulac aponta que o desenvolvimento temporal de um filme necessita de um movimento além da mera "agitação", um movimento que siga um princípio ativo e coordenador, que descreva um caráter interior. O significado do movimento cinematográfico deve surgir na busca pelo "invisível na arte visível”. O cinema, neste caso, é visto como um espelho da própria realidade em seu sentido de unidade orgânica.

Essa determinação de organicidade do real faz com que Dulac pressuponha uma referência externa sobre os métodos do cineasta: ele deve preservar essa unidade, conservá-la, de modo que o movimento constitua uma manifestação da harmonia interior. As condições básicas a serem respeitadas na apresentação das aparências seriam relativas à continuidade do registro dos movimentos, de seu desenvolvimento integral e na maneira como movimentos isolados são relacionados. ${ }^{20}$ Se não existem falhas no organismo da realidade, estas não devem existir em sua representação do cinema, portanto os cortes devem ser evitados, e quando utilizados, devem ter sua presença diminuída.

A precedência da realidade contínua para Dulac aponta para uma tendência a se considerar os meios técnicos como limites na representação. Ainda que ressaltados por sua capacidade de revelação, eles estariam em um nível inferior ao da realidade "em si”. Essa capacidade é relativa, marcando com isso o espaço para uma aspiração, o que ela chama de "filme integral",

cuja realização só será possível quando a nova arte ficar liberadas de seus "entraves", chegando ao cinema puro e autônomo - arte do movimento e dos ritmos visuais da vida e da natureza, ou "cinegrafia de formas", de linhas que se

19 Ibid., pp. 52-64.

20 Cf. Ismail Xavier, Sétima Arte: Um Culto Moderno (São Paulo: Perspectiva, 1978), pp. 70-80. 
tencionam, entram em luta, se unem, se abrem, e desaparecem, numa luta de brancos e pretos querendo dominar-se na tela. ${ }^{21}$

Alguns aspectos do mito de Bazin já se encontram no filme integral de Dulac. A crença na continuidade aliada à objetividade fotográfica como caminho para a revelação da unidade subjacente às aparências, bem como a desconfiança em relação aos procedimentos propriamente técnicos. A revelação faria com que os movimentos e ritmos da natureza seguissem suas próprias formas interiores - e não a expressão individual do artista -, o que significa que estaríamos frente à expressão da natureza por si mesma. O horizonte do real cerca o ideal do cinema, para Dulac como para Bazin.

Vertov, como Frampton, trilha outro caminho. Seu conceito de "Cine-Olho" trata das qualidades mecânicas do cinema, em sua capacidade de não apenas registrar fatos, mas de decompor e concentrar os fenômenos visuais. Para Vertov, "filmar tudo o que o olho viu resultaria em uma confusão. Editar artisticamente o que foi fotografado resultaria em uma clareza mais elevada". ${ }^{22}$ A atividade central para o compositor cinematográfico se torna então a montagem - a seleção e execução do tema, e o estabelecimento da ordem de exposição. O objetivo, segundo sua ótica revolucionária, é a revelação do processo dialético subjacente às atividades de produção baseadas em fatores históricos e culturais.

Em comum com Dulac, Vertov apresenta a busca por um fator "invisível”, uma organização da realidade a ser revelada pelas imagens. As diferenças entre eles não se encontram apenas na natureza dessa revelação, mas também na maneira como o cineasta compõe sua obra para que a revelação seja possível:

Para Vertov, mostrar a realidade na tela significa produzir um discurso através da organização de "fragmentos extraídos do real visível". A montagem marca a intervenção do realizador na reorganização das aparências, segundo uma perspectiva tendente a superar a imediatez das imagens, instaurando entre elas relações que serão responsáveis pelas significações produzidas pelo filme no

21 Ibid, p. 70. Dulac foi associada a um cinema considerado "impressionista", o que a afasta em alguns pontos das preferências de Bazin. O ponto de ligação entre os dois autores, como veremos mais à frente, é a naturalidade defendida na construção dos movimentos e do ritmo: a noção de que isso deve estar no próprio contexto das formas visuais, e não na imposição das técnicas composicionais.

22 Dziga Vertov, "Selected Writings", in P. Adams Sitney (ed.), The Avant Garde Film: A Reader of Theory and Criticism (Nova York: Anthology Film Archives, 1987), p. 5 e pp. 10-13. 
seu conjunto - a rede de relações permite tornar visível o invisível, ou seja, perceber a estrutura que está além das aparências. ${ }^{23}$

A inversão em Vertov ocorre, portanto, em dois níveis. Não apenas a realidade externa deixa de determinar absolutamente os métodos do cinema, como suas características mais profundas só seriam reveladas pela intervenção do cineasta. Em vez da manutenção de uma continuidade e objetividade "naturais", a superação dessas condições, que passam a ser vistas como apenas "imediatez". Não mais a continuidade, e não mais a natureza expressando a si mesma; a articulação dos elementos fílmicos seria o processo que direciona a obra ao seu sentido superior por um discurso que depende do choque de seus elementos para ser constituído.

Assim como o projeto de Dulac se volta para uma aspiração que leva suas defesas ao extremo, também no pensamento de Vertov encontramos apontamentos do que o cinema seria capaz caso suas diretrizes fossem levadas à máxima potência. Da montagem de fatos visuais registrados, Vertov comenta a possibilidade de passar aos "fatos visuais e acústicos", destes à "montagem simultânea de fatos visuais, acústicos, táteis, olfatórios, etc.", e então atingir o estágio em que "os próprios pensamentos serão registrados, e finalmente a organização direta desses pensamentos". ${ }^{24}$

Vertov não utiliza a analogia linguística tão abertamente como Frampton, mas sua obra, como a de outros cineastas russos do período, está repleta de procedimentos estruturais que remontam a figuras de linguagem. ${ }^{25}$ A montagem, como um processo global que inclui todos os sentidos e o próprio raciocínio, se torna um ponto de ligação crucial com o mito de Frampton: a composição cinematográfica não é propriamente linguística; ela é análoga à linguagem, um modelo estrutural que possibilita a expressão de conteúdos da consciência.

É preciso ter em vista o caráter ideal dessas propostas. Dulac e Vertov especulam sobre os resultados de seus métodos levados às últimas consequências; Bazin e Frampton elaboram narrativas que buscam justificar a condição do cinema enquanto arte; em todo caso, permanecem projetos em grande parte utópicos, como hipóteses de

\footnotetext{
Xavier, Op. cit., p. 74.

Ibid.

25 Annette Michelson ressalta alguns desses procedimentos em uma análise de $O$ homem com uma câmera (Chelovek s kinoapparatom, 1929), e descreve o filme como "um grandioso testamento a esta preocupação". Ver "From Magician to Epistemologist", in Sitney (ed.), The Essential Cinema, pp. 105-109.
} 
trabalho e pontos de referência. Aqui chegamos a um tópico crucial: o reconhecimento, por parte dos próprios autores, dos limites dessas justificativas, e eventualmente de suas contrapartes.

Bazin identifica duas tendências opostas no cinema da primeira metade do século XX. Além daquela defendida por ele, que acredita revelar a realidade sem acrescentar a ela, descreve outra que reside na exploração da significação pela articulação do registro através da montagem. Em suas palavras, haveria aqueles que "acreditam na imagem e os que acreditam na realidade". ${ }^{26} \mathrm{E}$ na frase que encerra seu ensaio sobre a ontologia da imagem fotográfica ${ }^{27}$, ele aponta ainda, brevemente, após todos os argumentos a favor da tendência realista, que, "por outro lado, o cinema é uma linguagem". ${ }^{28}$

Da mesma forma, Frampton, no texto para uma conferência, se diz em busca de uma "morfologia baseada na maneira como os filmes são feitos", e resume a composição cinematográfica em dois estágios: a filmagem e a montagem. Respectivamente, o ato de gerar o material fílmico e o ato de articular este material. Diferentes concepções de composição enfatizam uma ou outra etapa: alguns defendem que a montagem nada mais é que o último estágio de um esquema que preestabelece todas as características do material cinematográfico; para outros, a montagem é a decodificação racional das implicações desse mesmo material. Entre os dois pólos, como entre a filmagem e a montagem, ele reconhece que não há uma zona estritamente demarcada, mas um campo contínuo. ${ }^{29}$

Surge então um ponto importante para o entendimento dos mitos de Bazin e Frampton: a relação destes com a postura que reconhece a amplitude do campo do cinema, e mais ainda, que reconhece o alcance limitado de seus ideais. As razões para essa relação, como veremos, devem se localizar na própria constituição do pensamento dos autores, no desenvolvimento de seu programa teórico e na composição e análise de filmes.

${ }^{26}$ Bazin, "A evolução da linguagem cinematográfica”, in Op. cit., p. 96.

27 Jean-Michel Frodon revela que este trecho foi acrescentado nos últimos anos de vida de Bazin, não constando da versão original do ensaio. Frodon usa o acréscimo tardio como exemplo do constante questionamento de Bazin e do papel relativo que ele por vezes dava à sua ontologia. Ver "Film and Plaster", in Andrew (ed.), Opening Bazin, p. 78.

28 Bazin, "Ontologia da imagem fotográfica", in Op. cit., p. 34.

29 Cf. Frampton, "Notes on Composing in Film", in Jenkins, Op. cit., p. 155. Originalmente em October, $\mathrm{n}^{\circ} 1$, primavera de 1976. 
Brian Henderson sugere uma divisão dos textos de Bazin em dois grupos, os que exploram a "ontologia" realista e os que se voltam para questões críticas e históricas. Essa distinção, segundo Henderson, é um dos traços centrais de sua obra. Ao falar de filmes ou cineastas específicos, Bazin não se pergunta qual é o mais "realista" (logo, superior segundo sua ótica), mas sim como cada abordagem entende a realidade. $\mathrm{O}$ nível histórico não seria exatamente determinado pelo ontológico; este seria, antes, sua camada subjacente, e entre ambos haveria uma constante interação. ${ }^{30} \mathrm{O}$ princípio coordenador das qualidades da representação que Bazin descreve no seu mito parece, nesse sentido, ser um reflexo da própria relação entre sua ontologia e sua crítica histórica.

Noel Carroll sugere uma divisão parecida, ao apontar que o pensamento de Frampton resulta da convergência de duas perspectivas, que nomeia essencialista e histórica. A primeira busca identificar a "natureza" da arte e defender os estilos que melhor parecem explorá-la, enquanto a segunda busca um estudo crítico de seu desenvolvimento histórico. O que Carroll descreve como sendo um movimento entre "um essencialismo estático e uma apreciação inquiridora dos processos históricos" nos escritos de Frampton seria um modo de progredir em sua própria prática, de definir sua posição, tanto no presente como no quadro contínuo da evolução de sua arte. ${ }^{31}$

O que temos, portanto, é uma oposição entre ideais de cinema, mas também o reconhecimento de uma polaridade advinda dos métodos envolvidos na produção das obras e da necessidade de equilibrar as projeções teóricas com os fatos cinematográficos. A descida do "céu platônico" para Bazin, como da "mecânica celeste" para Frampton, efetua uma mesma operação: o direcionamento do olhar para as manifestações específicas do cinema, desde problemas gerais de seus elementos até o resultado particular da apropriação de seus meios por diferentes cineastas.

Se aceitamos as descrições de Andrew e Carroll para as duas principais vertentes do pensamento sobre o cinema, e se tomamos os ideais projetados por Bazin e Frampton como representantes desses direcionamentos opostos, devemos reconhecer que eles

30 Cf. Brian Henderson, “The Structure of Bazin's Thought”, in Film Quarterly, vol. 25, n 4, verão de 1972, pp. 18-27. Hugh Gray questiona a divisão de Henderson, argumentando que esta sugere uma inconsistência no pensamento de Bazin. A resposta de Henderson envolve uma ênfase ao caráter de interação aqui descrito, que garante não um ponto cego, mas um ponto de tensão adequado a uma visão dialética. Ver também "On Interpreting Bazin" e "Reply", in Film Quarterly, vol. 26, nº 3, primavera de 1973, pp. 58-61.

31 Cf. Noel Carroll, "A Brief Comment on Frampton's Notion of Metahistory", in Theorizing the Moving Image (Nova York: Cambridge University Press, 1996), pp. 313-315. 
dizem respeito acima de tudo às áreas mais extremas do espectro. E, se como foi ressaltado, os próprios autores reconhecem essa limitação e a necessidade de um confronto constante com as obras, devemos aceitar essa postura como suficientemente válida para uma investigação de sua interação.

Como podemos observar as manifestações concretas sem perder de vista as referências dos mitos? O campo do cinema, se pode ser mapeado, deve possuir os dois pólos, representados pelas áreas descritas no mito do cinema total e no da linguagem universal. Diametralmente opostos, os pólos sugerem a base de um sistema de coordenadas, o qual podemos imaginar como um globo. Posicionados em pontos menos receptivos à luz da análise direta, os mitos são, como os pólos no globo terrestre, mais áridos e menos propensos à difusão da vida, o que significa que obras específicas não surgem em suas dependências; são, como vimos, projetos utópicos, especulações sobre a essência da arte. A estrutura do pensamento de Bazin e Frampton, como descritas por Henderson e Carroll, por outro lado, nos permite investigar as outras áreas do globo a partir do eixo formado pela polaridade dos mitos. Se tanto Bazin como Frampton realizam um afastamento de seus ideais, podemos realizar um movimento semelhante, buscando nos aproximar das áreas mais distantes dos pólos desse globo, e que problematizam a divisão inicial.

Essa metáfora pode servir à determinação da complementaridade das referências, mas principalmente, ela serve à concepção de um campo a ser descrito. Tendo assumido essa configuração, restam áreas dispersas a serem investigadas: mais distantes dos pólos, atingidas com mais frequência pela luz, onde o idealismo é menos presente e, portanto, a análise de obras é mais fértil.

Nos capítulos seguintes, o movimento em direção às obras será realizado gradualmente. Os pensamentos de Bazin e Frampton serão comparados em três etapas. Primeiramente, através de suas interpretações da origem do cinema, em especial sua filiação fotográfica e inclusão no sistema das artes. Em seguida, através de suas descrições do que seriam os elementos básicos do cinema, as categorias e ferramentas que os artistas devem utilizar em suas obras. Finalmente, através de seus comentários voltados a obras que julgavam representar alguns dos tópicos defendidos, ou que serviram de base para sua formulação. Veremos em quais pontos eles concordam, em quais divergem, e em quais podemos realizar uma aproximação ou cruzamento. 
II.

A HERANÇA FOTOGRÁFICA E O LUGAR DO CINEMA NO SISTEMA DAS ARTES 


\section{O complexo da múmia}

Bazin inicia seu ensaio sobre a ontologia da imagem fotográfica com o que chama de "uma psicanálise das artes plásticas", identificando um fato fundamental de sua origem na prática do embalsamamento. A concepção do corpo como um invólucro da vida e a fixação de suas características como a manutenção de sua perenidade são apontadas por ele como cruciais em toda a orientação da religião egípcia. A restituição das aparências como defesa contra o tempo: é essa função que Bazin considera central para o entendimento das artes plásticas, sendo realizada, no caso das múmias egípcias, na própria materialidade do corpo. "O desejo de sobreviver”, na expressão de Élie Faure, acordava nos egípcios a eternidade individual "de que a duração dos fenômenos cósmicos lhes dava a vã aparência". ${ }^{32}$

A necessidade de exorcizar o tempo se altera com a destituição das funções mágicas da arte e o fim da crença na identidade entre o modelo e o retrato. A múmia é o próprio corpo, mas uma escultura ou uma pintura permanecem objetos diferentes daquilo que representam. Bazin nos lembra que Luís XIV não se fez embalsamar: contenta-se com seu retrato pintado. Não sendo mais necessária a relação de identidade entre o representado e a representação, a importância da fabricação de imagens passa para a construção de um universo ideal à semelhança do real. ${ }^{33}$

A fotografia e o cinema, para Bazin, podem explicar a "grande crise espiritual da pintura moderna". Em consonância com André Malraux, ele coloca o cinema como uma instância mais evoluída do realismo plástico que teve início no Renascimento. $\mathrm{O}$ acontecimento decisivo do período teria sido a invenção da perspectiva, o sistema científico que permite ao artista a elaboração de uma ilusão de espaço tridimensional, e consequentemente a disposição dos objetos como se apresentam à nossa percepção direta. $^{34}$

Desde então, a pintura viu-se esquartejada entre duas aspirações: uma propriamente estética - a expressão das realidades espirituais em que o modelo se acha transcendido pelo simbolismo das formas -, e outra, esta não mais que

32 Élie Faure, A Arte Antiga (Lisboa: Estúdios Cor, 1951), p. 46.

33 Bazin, "Ontologia da imagem fotográfica", Op. cit., pp. 27-28.

34 Ibid., pp. 28-29. 
um desejo puramente psicológico de substituir o mundo exterior pelo seu duplo. Esta necessidade de ilusão, que aumentava rapidamente por sua satisfação mesma, devorou pouco a pouco as artes plásticas. Porém, tendo a perspectiva resolvido o problema das formas, mas não o do movimento, era natural que o realismo se prolongasse numa busca da expressão dramática do instante, espécie de quarta dimensão psíquica capaz de sugerir a vida na imobilidade torturada da arte barroca. ${ }^{35}$

Se a perspectiva foi "o pecado original da pintura ocidental", a fotografia foi sua redentora, livrando-a da obsessão pela semelhança através da objetividade essencial de sua gênese. Ainda que a fotografia continuasse inferior à pintura por algum tempo na imitação das cores, era sua objetividade que a conferia uma credibilidade ausente nas artes plásticas. Este é o ponto reforçado por Bazin, e onde se deve desfazer o malentendido entre o realismo "estético" e o "psicológico". O primeiro seria o pseudorealismo, contente com a ilusão das formas, como no trompe l'oeil; o segundo seria a expressão de um significado "a um só tempo concreto e essencial do mundo". O desenvolvimento de técnicas pictóricas para instituir uma ilusão de semelhança com o mundo visível deixa de ser um objetivo para a pintura quando ela se defronta com uma tecnologia que o realiza sem o esforço construtivo do homem, e que institui não apenas a semelhança, mas ainda uma relação de identidade. É a dependência deste segundo modo que torna a fotografia importante em relação à pintura, pois sua objetividade não se encontra em seu resultado, em sua aparência, mas no fato psicológico advindo do elemento mecânico em sua origem. ${ }^{36}$

A fotografia representa "literalmente" os objetos. A imagem pode vir a ser nebulosa ou descolorida, mas sua objetividade garante que ela "é" o modelo. Assim como na descrição do realismo feita por Andrew, aqui é o próprio traçado da luz que garante essa relação ontológica. Bazin enfatiza o fator natural do processo, diminuindo o papel do artista como responsável pela constituição da obra:

Pela primeira vez, uma imagem do mundo exterior se forma automaticamente, sem a intervenção criadora do homem, segundo um rigoroso determinismo. A personalidade do fotógrafo não entra em jogo senão pela escolha, pela

35 Ibid., p. 29.

36 Ibid., pp. 29-30. 
orientação, pela pedagogia do fenômeno; por mais visível que seja na obra acabada, já não figura nela como a do pintor. Todas as artes se fundam sobre a presença do homem; unicamente na fotografia é que fruímos da sua ausência. Ela age sobre nós como um fenômeno "natural", como uma flor ou um cristal de neve cuja beleza é inseparável de sua origem vegetal ou telúrica. ${ }^{37}$

A base fotográfica do cinema o colocaria como herdeiro dessa objetividade, com o acréscimo da dimensão temporal. Se a fotografia "embalsama o tempo" (Bazin usa como exemplo os corpos dos insetos intactos no âmbar), o cinema nos dá a própria duração das imagens, mantendo, portanto, a mesma relação ontológica, "uma múmia da mutação", 38

Podemos amplificar o ponto de vista de Bazin e entender alguns de seus fundamentos retomando o contexto em que a Estética surge como uma disciplina autônoma: as discussões sobre as belas-artes no século XVIII. O tratamento teórico que levou à criação de um subconjunto da filosofia teve seus alicerces na defesa, por Charles Batteux, de um princípio comum, a "imitação da bela natureza". 39

Este princípio seria único às belas-artes, que têm como objeto o prazer, e que "só puderam nascer no seio da alegria e dos sentimentos que produzem a abundância e a tranquilidade". Entre as belas-artes estão, por exemplo, a música, a pintura e a poesia. As chamadas artes mecânicas, por outro lado, não são empregadas tendo em vista o prazer, mas as necessidades do homem que exigiram sua criação. Haveria ainda um terceiro tipo - exemplificado pela arquitetura - de artes que combinam características dos dois grupos anteriores: "foi a necessidade que as fez eclodir, e o gosto que as aperfeiçoou". Enquanto as artes mecânicas empregam a natureza tal como ela é, visando seu uso, as artes do terceiro grupo a empregam "polindo-a, para o uso e para o encanto"; mas as belas-artes não utilizam a natureza no mesmo sentido, apenas a imitam, cada uma à sua maneira. Essas maneiras, para Batteux, não são criadas arbitrariamente, e sim traçadas a partir do próprio exemplo da natureza. ${ }^{40} \mathrm{O}$ artista deve transpor traços dessa Philosophy and Rhetoric, vol. 40, n 3, 2007, p. 337. Para mais detalhes sobre a divisão das artes neste contexto, ver Paul Oskar Kristeller, "The Modern System of the Arts", in Renaissance Thought and the Arts (Nova Jersey: Princeton University Press, 1980).

40 Charles Batteux, As Belas-Artes Reduzidas a um Mesmo Princípio (São Paulo: Humanitas, 2009), pp. 23-27.
} 
natureza para objetos que não são naturais, elaborados tendo como único fim a imitação. $^{41}$

É sobre o pensamento de Batteux que autores como Moses Mendelssohn e Gotthold Lessing constroem suas próprias investigações, e enfatizam diferentes aspectos desse sistema. Mendelssohn reforça os diferentes signos pelos quais as artes realizariam a imitação. Ele afirma que artes como a poesia e a retórica fazem uso de signos arbitrários, que não possuem nada em comum com o tema designado. A linguagem, por esse ponto de vista, não é retirada diretamente da natureza, mas desenvolvida pelo homem; sua estrutura independe dos temas e procedimentos utilizados na imitação. Outras artes fariam uso de signos naturais: a música, através da justaposição de sons; a dança, pela sucessão de movimentos visualizados; a pintura, através da justaposição de formas visuais em superfícies; a arquitetura e a escultura, pela justaposição de formas e corpos no espaço. ${ }^{42}$

Lessing, por sua vez, divide as artes em espaciais e temporais. As primeiras, como a pintura e a escultura, são ações inertes, em que as diferentes partes se desenvolvem uma ao lado da outra; as segundas, como a música e a poesia, são ações progressivas, em que as diferentes partes se desenvolvem uma após a outra. Confrontadas com os mesmos temas e eventos, as artes devem então recorrer a diferentes estratégias: enquanto à poesia é possível narrar uma série de ações de modo a criar uma sucessão de causas que leva de um termo a outro, à escultura tal possibilidade é negada pela simultaneidade espacial de suas partes; da mesma forma, a pintura pode selecionar um único momento e dele extrair toda a sua expressividade, enquanto a música deve transformar esses fatores em etapas e processos a serem apresentados em uma ordem específica. ${ }^{43}$

A genealogia de Bazin não discute em qual dos grupos o cinema se encaixaria. Sua concepção da fotografia, assim como sua definição do cinema total, parece apontar para uma adequação às artes voltadas para a necessidade - o cinema, como produto dos inventores, possui, afinal, uma aplicação científica -, mas a dimensão artística também é

${ }^{41}$ Cf. Leonardo da Vinci, Treatise on Painting (Londres: J. Taylor, 1802), p. 206. "O homem não deve confiar em si mesmo, mas consultar a natureza. Qualquer um que se gabe de manter na memória todos os efeitos da natureza é enganado, pois nossa memória não é tão capaz; deve, portanto, consultar a natureza para tudo."

42 Moses Mendelssohn, Philosophical Writings (Cambridge University Press, 1997), pp. 177-178.

${ }^{43}$ Gotthold E. Lessing, Laocoon (Boston: Roberts Brothers, 1887), p. 90. 
considerada, e a função mimética é priorizada, permanecendo em consonância com o que Batteux entende por imitação, a função das belas-artes.

É evidente que Bazin considera o cinema como uma das artes que faz uso de signos naturais. Ele se refere ao "universo ideal" da pintura partindo da mesma postura de Batteux, de que as artes em geral operam através da semelhança, com materiais diferentes dos objetos representados. Batteux e Mendelssohn, numa época anterior à fotografia, consideram como "naturais" os signos que realizam a imitação a partir dos mesmos parâmetros que elas visam articular. A pintura e escultura, por exemplo, apresentam o caráter visual e tátil dos objetos, sendo elas próprias construções visuais e táteis, enquanto a linguagem, utilizada pela poesia e retórica, deve descrever relações entre objetos a partir de algo desenvolvido à parte destes. O argumento de Bazin é que a entrada da fotografia no sistema das artes acrescenta uma nova possibilidade, a de que

os objetos representem a si mesmos. É a própria constituição deles que visualizamos nas imagens fotográficas, assim como é sua própria duração física que visualizamos no cinema. A nova possibilidade, vista dessa forma, efetua um retorno à relação física do embalsamamento, pois a fotografia, ainda que não seja o próprio objeto, é seu rastro luminoso, portanto a marca de sua existência no espaço. Este é o fato em cuja extensão podemos reconhecer a mesma disposição comentada por Dulac, de que o movimento "concreto e essencial" expressa um princípio de realidade por meio de um processo automático.

O cinema também compartilha as duas categorias definidas por Lessing. Assim como a pintura e a escultura, possui um aspecto espacial; sua base fotográfica não apenas realiza a apresentação do espaço tridimensional através da semelhança, mas também a confirmação psicológica de sua materialidade. E assim como a música e a poesia, possui um aspecto temporal, de modo que o desenrolar das imagens no tempo torna inevitável a submissão destas a um mesmo processo. A representação dos eventos se abre à possibilidade da síntese pela simultaneidade, como na pintura, tanto quanto à transformação desta por diferentes etapas, como na poesia.

As condições das quais dependiam as artes espaciais ou temporais de Lessing são então reformuladas pelo cruzamento das duas categorias. Com o cinema, não apenas não é necessário que a composição espacial busque sintetizar o tempo através de uma sugestão que só existe por sua ausência, como a própria configuração da imagem fílmica pensada por Bazin torna problemática essa separação. Jean Mitry nos lembra 
que a profundidade da imagem no cinema, e seu "efeito de realidade", dependem diretamente de sua integração a uma série contínua:

\begin{abstract}
Enquanto a imagem em uma pintura ou fotografia (que sugerem a dimensão através do efeito de perspectiva) dá a impressão do relevo ao permanecer fixa a uma superfície, a imagem fílmica, através do movimento que reproduz, acentua essa impressão tornando-a uma genuína sensação. ${ }^{44}$
\end{abstract}

Uma demonstração deste princípio ocorre quando um único fotograma é repetido sucessivamente: o relevo e o desenrolar do movimento são substituídos por um achatamento da imagem, assim como de sua duração. A experiência do espaço e do tempo permanece, pois ambos são inevitáveis no cinema, mas a representação de sua continuidade e integração é quebrada. Nesse sentido, a unidade defendida por Bazin só é alcançada através da codependência das duas categorias, da submissão de ambas ao princípio realista que encontramos no mito do cinema total.

44 Jean Mitry, The Aesthetics and Psychology of Cinema (Bloomington: Indiana University Press, 2000), p. 73. Para uma discussão sobre essa definição, ver também Edward Branigan, "What is a Camera?", in Patricia Mellencamp e Philip Rosen (ed.), Cinema Histories, Cinema Practices (University of Michigan, 1984), p. 89. 


\section{A criatura do momento}

Os comentários de Frampton sobre fotografia se revelam mais numerosos que os de Bazin, consequência de sua atividade artística, tendo se dedicado à fotografia antes do início de sua carreira como cineasta. Suas reflexões tomam a forma de críticas dos nomes tomados por ele como referências pessoais, seu próprio "conjunto de monumentos". Ensaios sobre Muybridge, Paul Strand e Edward Weston, além de outros fotógrafos (como Fox-Talbot e Marey) abordados indiretamente em textos sobre questões específicas, são os pontos de partida para explorar os tópicos de seu interesse, nos quais reencontramos alguns aspectos do seu mito.

Assim como Bazin, Frampton apresenta uma narrativa que determina a posição do cinema no sistema das artes. Para descrever o surgimento da fotografia, ele propõe que vejamos cada obra de arte como possuindo duas partes: uma "estrutura deliberada", formada pelos elementos e operações aparentes, conscientemente disposta pelo artista, e uma "subestrutura axiomática", formada por tudo que o artista, conscientemente ou não, considerou auto-evidente o bastante para não justificar. Axiomas estão sujeitos a alterações, mas se a subestrutura é entrevista apenas através da estrutura, eles permanecem inconscientes; para que as raízes da arte possam ser interpretadas, a atenção deve se voltar diretamente para os axiomas. ${ }^{45}$

A fotografia, para Frampton, surge num momento em que "se sabia o que era arte". As suposições axiomáticas estavam estabelecidas, e no caso da fotografia, suas suposições eram aquelas da pintura. Dessa forma, as condições estavam determinadas: a fotografia, como a pintura, imitava a natureza através de imagens. No final do século XIX, a pintura começa a examinar suas próprias suposições e descarta aquelas entregues à fotografia, que havia se bifurcado: de um lado, o "registro fotográfico" (o potencial utilitário das artes mecânicas); do outro, a "arte fotográfica" (o potencial estético, como nas belas-artes). O primeiro segue seu próprio caminho, enquanto a segunda imita a pintura tradicional. ${ }^{46}$ Seguir o próprio caminho, nesse caso, diz respeito ao confronto com a subestrutura axiomática da fotografia, suas condições específicas, inevitáveis.

\footnotetext{
45 Cf. Frampton, "Meditations around Paul Strand", in Jenkins, Op. cit., p. 131. Originalmente em Artforum, Vol. 10, nº 6, fevereiro de 1972.

46 Ibid.
} 
Em princípio, seria possível livrar uma arte de tudo, menos de suas próprias especificidades. Podemos nos ver livres de pessoas, animais, objetos, paisagens, e ainda assim ter uma pintura ("um código desprovido de tudo exceto sua própria descrição"). Mas a fotografia parece impossível de ser dissociada da mesma maneira, pois ao afirmar a existência de seu pretexto, ela parece depender dele ontologicamente. A natureza ("tudo do outro lado da câmera") é a gramática, e também a sintaxe da fotografia. Se tentássemos livrar a fotografia de suas especificidades, teríamos uma imagem branca, e se tentássemos livrar a impressão fotográfica teríamos apenas um pedaço de papel. Nas palavras de Frampton, "não podemos fazer uma fotografia que seja uma imagem de nada". 47

Essa tendência à autodefinição, à determinação das especificidades, é um procedimento tipicamente modernista, que Clement Greenberg identifica como sendo "a intensificação da tendência autocrítica iniciada pela filosofia kantiana". O cerne do modernismo estaria no uso de métodos característicos para que uma discipline critique a si mesma, para afirmá-la mais firmemente em sua área de competência. Segundo Greenberg, as vanguardas modernistas enfatizaram o "instinto de autopreservação das artes". As belas-artes, na concepção iluminista, procuraram demonstrar quais tipos de experiência deveriam ser imitados, e que por si só seriam válidos; a via do modernismo, por outro lado, consiste na demonstração do que é irredutível a cada arte, seu terreno particular, exclusivo. A tarefa da crítica modernista é, portanto, eliminar efeitos compartilhados com outras artes. Surge assim a noção de que a garantia de eficiência de uma arte, a definição de sua pureza, coincide com a definição de seu próprio meio. ${ }^{48}$ As teorias de Batteux, Mendelssohn e Lessing, ao tentar delinear como cada arte tornaria possível a imitação de acordo com diferentes meios, são de certa forma os primeiros passos para a vertente autocrítica que resulta no modernismo. À homogeneidade do objetivo das artes se soma a heterogeneidade de seus meios.

Para Frampton, Weston foi o primeiro a propor essa abordagem na fotografia, identificando a obra com seu próprio material. Isso exige que se determine a natureza do

47 Frampton, "Impromptus on Edward Weston: Everything in its Place", in Jenkins, Op. cit., p. 141. Originalmente em October, n $^{\circ}$ 5, verão de 1978.

48 Clement Greenberg, "Modernist Painting”, in John O'Brien (ed.), Clement Greenberg - The Collected Essays and Criticism, vol. 4: Modernism with a Vengeance, 1957-1969 (University of Chicago Press, 1988), pp. 85-86. 
material, e que seus atributos sejam limitados. Mas também gera um problema, pois a fotografia seria identificada duas vezes: com ela mesma, e com seu referente. ${ }^{49}$

Frampton sugere então uma saída para o problema, baseando-se em certos nomes do modernismo literário. Ele nos diz que, nas obras de Samuel Beckett, Jorge Luis Borges e Alain Robbe-Grillet, é utilizada uma estratégia que denomina "deslocamento", que consiste em desfazer sistematicamente as conexões causais e temporais, tornando-as virtualmente irrelevantes, e igualando o texto com a ilusão de uma imagem. Isso resultaria em textos que são nada mais que descrições minuciosas e "planas" de espaços, de objetos dispostos nesses espaços, de atributos volumétricos desses objetos - e em que "nada parece acontecer". A causalidade e a temporalidade seriam retiradas do texto, e estaríamos assim frente não a uma representação de um espaço desenvolvido cronologicamente, mas à construção gradual de um espaço, em nossa consciência, que reflete a atemporalidade do próprio tex to. ${ }^{50}$

$\mathrm{Na}$ obra de Weston encontramos uma estratégia semelhante. O conjunto de pretextos possíveis é reduzido a uma série de categorias abstratas, baseadas na pintura ilusionista (retrato, paisagem, natureza morta, etc.). A ênfase é dada às superfícies, diminuindo a profundidade e identificando a imagem plana com a própria impressão fotográfica. Há uma recusa completa pelo snapshot, o registro de momentos fugidios que sugiram o movimento por sua configuração espacial. Com os pretextos isolados e abstraídos, com o espaço suprimido e refletido na própria materialidade da fotografia, e com a sugestão de movimento neutralizada, Weston "retiraria as coisas das garras da causalidade, resgatando-as do inferno da entropia". 51

Outras estratégias, tentativas de compressão ou expansão do tempo cronológico, seriam encontradas nas séries de Eakins, Muybridge e Marey. O fato de as publicações de Muybridge se darem na forma de livros é um exemplo de disposição que possibilita acesso aleatório às placas, portanto uma decomposição do movimento em elementos dispersos e observáveis de acordo com outra lógica que não a da cronologia linear. Entre seus contemporâneos, Frampton cita Leslie Krims e Duane Michals como aqueles que estariam buscando revelações na própria estrutura da série, como nas sequências circulares e paradoxais de Michals que parecem subverter o tempo construindo loopings

\footnotetext{
49 Frampton, "Impromptus on Edward Weston: Everything in its Place", in Jenkins, Op. cit., p. 142.

50 Ibid., p. 143.

51 Ibid., pp. 143-144.
} 
e labirintos narrativos. ${ }^{52}$ Torna-se claro, por essa solução e pelos exemplos citados, que Frampton considera a sugestão da temporalidade um fator a ser combatido na fotografia, seja em obras isoladas ou partes de um conjunto.

Paul Strand também é colocado como um dos modernistas que buscaram estabelecer a própria prática a partir de uma definição dos fundamentos da fotografia. Seu pensamento é resumindo em três pontos. Primeiro: a estrutura da imagem fotográfica é absolutamente ligada à ilusão. Os fotógrafos devem se comprometer, com a maior fidelidade possível, à realização tátil e espacial dessa ilusão. Segundo: dois fotógrafos, independente de suas habilidades ilusionistas, não fazem fotografias comensuráveis do mesmo pretexto. Essas diferenças devem ser consideradas; elas devem se situar na subestrutura axiomática da obra, entre suas suposições epistemológicas. O que leva ao terceiro ponto: cada parâmetro do processo fotográfico (forma, textura, linha, cor) implica e define uma visão da realidade. ${ }^{53}$

Strand condena a tendência, comum em seu tempo, de adaptar práticas da pintura ao trabalho fotográfico: a manipulação dos parâmetros da câmera, como o foco e a lente, ou mesmo a superfície do negativo e da impressão, em busca de resultados que se situem além da esfera objetiva do processo. ${ }^{54} \mathrm{Na}$ defesa dos aspectos que considera específicos na fotografia, e da concretização desses aspectos pela restrição técnica do fotógrafo, Strand parece estar em consonância com a visão de Bazin. Mas a interpretação de Frampton nos leva a outro resultado; a objetividade fotográfica para ele é parte fundamental do processo, mas como uma espécie de catalisadora entre a consciência e a realidade exterior.

Frampton torna mais clara sua posição quando comenta uma fotografia de Henry Fox-Talbot tirada em Lake Como. Ele começa nos lembrando que o lago em si, desprezando variações estatísticas mínimas, é imutável - ou seja, um pretexto que, para os fins da sensibilidade humana, é razoavelmente independente de suas condições temporais. Em seguida, examina as circunstâncias da visita de Talbot: longe de casa, em um lugar estranho ao qual poderia nunca mais retornar, ele estaria imerso na tentativa de "desenhar" a paisagem (Frampton se refere ao prefácio de The Pencil of Nature para justificar o termo). A mudança fundamental viria com a realização de que a imagem que

\footnotetext{
52 Cf. Frampton, "Incisions in History / Segments of Eternity", in Jenkins, Op. cit., p. 104. Originalmente em Artforum Vol. 13, no 2, outubro de 1974.

53 Frampton, "Meditations around Paul Strand", Op. cit., p. 132.

54 Cf. Paul Strand, "Photography", in Camera Work, no 40/50, 1917, pp. 3-4.
} 
o artista deseja representar já se encontra lá. Essa realização, como um momento extático, é o que Frampton diz ser uma negação da temporalidade. O que Talbot "vê" não é uma simples paisagem que o entrega imagens naturalmente, mas "a radiância de seu próprio insight", a realização de que "a criatura do momento, logo destinada a desaparecer, era ele próprio". ${ }^{55}$ Frampton continua:

podemos imaginar, em resumo, que a fotografia é precisamente "sobre" esses reconhecimentos, formações, percepções, suspensões, persistências, hesitações na mente que precedem, se não completamente prevêem, aquela descoberta, a peripateia, o desenrolar-em-movimento e a inspiração que é a consciência articulada. ${ }^{56}$

Este trecho demonstra como Frampton efetua um redirecionamento das preocupações que em Bazin se voltam para o aspecto automático da fotografia e que o levam a diminuir o papel do artista envolvido no processo. Frampton coloca na própria intervenção do fotógrafo, independente de quão mínima ela seja, o fardo da fotografia como arte. A disposição dos pigmentos sobre a superfície sensível, o traçado da luz resultante da configuração da câmera em determinado espaço, tudo isso, ainda que dependente da natureza à qual Talbot acreditava dar as ferramentas para desenhar a si mesma, seria uma representação da consciência do artista.

Outro tópico abordado por Frampton parece acrescentar uma nova camada a essa questão. Ele nos lembra que o negativo fotográfico possibilita a geração de uma infinidade de cópias, sendo comparável ao baixo cifrado nas partituras barrocas - um campo retórico permitindo variações sobre um mesmo elemento. O fotógrafo, nesse sentido, é o intérprete de seus negativos, tanto como da realidade visível.

Essa associação da fotografia com a música e da multiplicação dos objetos fotográficos a partir de uma mesma matriz remonta às questões abordadas por Nelson Goodman em seu livro Languages of Art. Goodman propõe que chamemos de alográficas as artes em que a distinção entre o objeto original e a cópia não é significativa, e de autográficas as artes em que essa distinção é crucial. Na pintura, por exemplo, o objeto gerado pelo pintor na forma do quadro é a própria obra, de modo que rascunhos e reproduções não passam de tentativas aproximadas de prever ou repetir o

55 Frampton, "Incisions in History / Segments of Eternity", Op. cit., p. 93.
Ibid., p. 100. 
objeto original, e por isso são consideradas inferiores. ${ }^{57} \mathrm{Na}$ música, por outro lado, a partitura serve como um mapa para as performances, que podem variar dentro de certos parâmetros, fazendo com que diferentes performances possam revelar diferentes potencialidades da obra-matriz. A pintura seria uma arte autográfica, como a escultura; a fotografia, como a música, seria uma arte alográfica. ${ }^{58}$

A conclusão de Frampton é que a ligação ontológica entre a imagem e o pretexto faz com que cada obra fotográfica pareça "iniciar e terminar toda a arte da fotografia". $\mathrm{Na}$ pintura, veríamos uma relação oposta. Cada fenômeno possui sua fotografia correspondente e cada fotografia possui seu pretexto particular, mas o gesto do pintor é de outra ordem: não tendo uma relação ontológica direta com a realidade, ele deve ser compreendido como "uma metáfora para a relação entre a consciência criadora e a realidade exterior". ${ }^{59}$ Nesse sentido, a arte da pintura, como um todo, seria maior que qualquer uma de suas obras. ${ }^{60}$

É importante notar que, apesar de reforçar a relação ontológica entre a fotografia e seu pretexto, Frampton entende que ela coexiste com o caráter matricial dos negativos. A fotografia está ao mesmo tempo ligada inextricavelmente ao seu fenômeno correspondente $e$ aberta à interpretação do fotógrafo através da manipulação do negativo. Além disso, Frampton considera como "pretexto" tudo que é passível de fixação no material sensível:

O traçado feito pela luz no material sensível é uma imagem. Uma câmera pode ter estado envolvida, ou não. A luz pode ou não ter sido focada por uma lente. A

57 Hugh Kenner aponta alguns dos problemas que surgem quando procuramos considerar apenas "o artefato". Ele argumenta que, por esta ótica, somos incapazes de determinar, por exemplo, o que diferencia um falso Vermeer de um verdadeiro, exceto o fato de que um deles não foi pintado por Vermeer. Cf. Kenner, The Counterfeiters (Londres: Dakley Archive Press, 2005), pp. 29-31. O mesmo argumento é desenvolvido por Nelson Goodman, na obra citada na nota seguinte. Um dos textos canônicos e que propõe uma base filosófica para o tema é "A obra de arte na era da reprodutibilidade técnica" de Walter Benjamin, in Obras Escolhidas, vol. I (São Paulo: Brasiliense, 1985).

58 Nelson Goodman, Languages of Art (Indianapolis: Hackett, 1976), pp. 113-114.

59 Ibid., pp. 129-130.

${ }^{60}$ Frampton parece considerar aqui exclusivamente a pintura tradicional. Podemos perceber, por esses questionamentos, uma das razões de seu interesse pela chamada action painting, que parece coincidir com seu interesse pela obra de Stan Brakhage, em especial o que ele identifica como sendo a "diç̧ão" da câmera de Brakhage, uma herança do expressionismo abstrato. A ênfase no gesto da pintura faria com que cada obra se tornasse um registro praticamente fotográfico de uma performance sobre um campo de possibilidades composicionais, assim como a constante movimentação e a proeminência da subjetividade da câmera nos filmes de Brakhage. Ver "Talking About Magellan: An Interview", in Jenkins, Op. cit., pp. 245-247. Originalmente em Millennium Film Journal, no 7-9, outono/inverno de 1980-81. 
imagem pode muito bem não parecer com uma vaca, ou com Simonetta Vespucci; mas por ser uma imagem fotográfica, está sujeita aos mesmos procedimentos. Mais importante: é acessível às nossas sensibilidades precisamente sobre a mesma base. ${ }^{61}$

Se "cada fenômeno possui sua fotografia correspondente", diferentes exemplares de uma mesma fotografia, impressos de maneiras diferentes, não reforçam necessariamente os mesmos aspectos dessa correspondência. O exemplar fotográfico, como objeto, seria tão correspondente ao seu fenômeno quanto ao ato da impressão, às manipulações efetuadas no negativo. E se "o fotógrafo ajusta sua sensibilidade sobre toda a imagem, modificando seus parâmetros", a correspondência de cada objeto particular seria precisamente a essa sensibilidade, à "criatura do momento", fixada no material como uma projeção da consciência do artista.

61 Frampton, "Some Propositions on Photography", in Jenkins, Op. cit., pp. 6-7. 


\section{Entre o sujeito e o objeto}

Bazin coloca como fundamento da imagem fotográfica a objetividade em relação à realidade. Essa objetividade não é simplesmente a semelhança visual, mas uma relação ontológica, também reconhecida por Frampton, e citada por ele como uma espécie de reflexo automático: sabemos que a fotografia depende de seu pretexto, logo, aceitamos a imagem como correlata de um evento. Não há nenhuma necessidade de demonstração ou investigação envolvida.

Para Bazin, essa é essencialmente uma relação de crença, e é dela que viria o arrebatamento da fotografia, justificando sua preferência pelo que chama de realismo psicológico. O papel do artista, nessa situação, é diminuído; sua personalidade entra em jogo apenas pela "pedagogia do fenômeno". A defesa da intervenção mínima é mais uma vez expressa pela descrição do processo fotográfico com um processo natural. A comparação de Walter Benjamin, entre o mágico e o cirurgião, se dá numa chave parecida. Benjamin considera que o pintor é como o mágico, alguém que "preserva a distância natural entre ele e o paciente, ou antes, a diminui um pouco, e a aumenta muito, graças à sua autoridade", enquanto o fotógrafo é como o cirurgião, alguém que "diminui muito sua distância em relação ao paciente, ao penetrar em seu organismo, e a aumenta pouco, devido à cautela com que sua mão se move entre os órgãos", $62 \mathrm{O}$ paciente - no caso, aquele que é o objeto de intervenção de ambos - seria a própria realidade sensível. A distância dela para o pintor é pouco diminuída, por um lado, pois se baseia numa construção manual, em que cada traço implica um acréscimo consciente, mas muito aumentada, por outro, pois sua autoridade como construtor é afirmada na mesma medida. A distância dela para o fotógrafo é muito diminuída, por um lado, pois ele utiliza os próprios meios da realidade para formar a imagem, e por outro lado é pouco aumentada, pois a relação de identidade entre a realidade e a imagem depende justamente de sua desaparição como construtor.

Frampton reforça o pólo contrário ao afirmar o papel do artista como central na fotografia. Se há alguma correspondência entre o evento e seu registro, a configuração técnica e propriamente estética que permite essa correspondência deriva justamente da consciência do artista. O comentário sobre Fox-Talbot é crucial para o entendimento

\footnotetext{
${ }^{62}$ Benjamin, Op. cit., p. 187.
} 
desse posicionamento: a fotografia, como um todo, é sobre a consciência, e cada fotografia particular é sobre o processo consciente que nela se cristalizou através da realidade visível. Enquanto o pintor projeta sua consciência na "entrega à contemplação do espaço perceptível", através de seus atributos (massa, volume, cor, gradação), e através de um processo que é essencialmente plástico, o fotógrafo lida com esse mesmo espaço de uma maneira completamente diferente, pois seus procedimentos envolvem os eixos pelos quais medimos essa plasticidade, "e a plasticidade de nossa própria percepção". A articulação do pintor acrescenta fisicamente elementos que formam a imagem, enquanto a articulação do fotógrafo ajusta toda a imagem, de uma só vez, de acordo com suas sensibilidades. ${ }^{63}$

Devemos acrescentar a isso ainda o desenvolvimento da noção do fotógrafo como o intérprete de seus negativos. Para Frampton, cada um dos pretextos pode ser articulado de acordo com parâmetros que não dependem de seu contexto natural, mas da própria intervenção do artista. Nos termos de Mendelssohn, o signo fotográfico para Frampton não seria completamente natural, pois haveria um componente arbitrário da parte do fotógrafo (ou seja, como na linguagem). Em Bazin não encontramos essa preocupação: ele defende que o evento é "embalsamado" pelo processo fotográfico, e que a fotografia, como objeto, é apenas um veículo, tornando visível o traçado da luz que permite a representação através da disposição material no negativo. Se a fotografia, na visão de Frampton, “embalsama” um evento, não o faz através dos objetos concretos, mas da estrutura de pensamento que os registrou em determinada posição e momento. $\mathrm{O}$ que interessa a Bazin não é a fotografia como algo, mas como um nada que torna algo visível. ${ }^{64}$

A discordância prossegue na relação entre a fotografia e o cinema. Por um lado, Bazin enxerga na sucessão de fotografias a possibilidade de acrescentar uma dimensão à representação. O mito do cinema total permanece como a imagem de fundo, estabelecendo a integração direcionada dos aspectos fotográficos e cinematográficos: a imitação do mundo à sua própria imagem, através de signos naturais, portanto hierarquicamente superior às articulações conscientes do artista, vistas negativamente como arbitrárias. Frampton, por outro lado, defende que não há uma relação de necessidade, uma exigência lógica, que faça com que a fotografia "seja acelerada até o

63 Frampton, "Some Propositions on Photography", in Jenkins, Op. cit., pp. 6-7.

${ }^{64}$ Cf. Dudley Andrew, What Cinema Is: Bazin's Quest and its Charge (Oxford: Wiley-Blackwell, 2010), p. 13. 
cinema". Ele argumenta que tecnologias como o zootrópio constituem um ramo distinto da pré-história fílmica (pois inicialmente eram compostos por desenhos), sendo apenas mais tarde cruzado com a imagem fotográfica. Argumenta ainda que a própria ilusão do movimento não deve ser considerada como inevitável. ${ }^{65}$ Essa suposição, ele diz, se baseia na noção de que o intervalo entre um fotograma e outro varia apenas brevemente, mantendo certa continuidade sob um padrão estável. A continuidade depende da utilização conjunta da câmera com a manutenção da integridade do registro durante a montagem; como outras possibilidades se apresentam em ambas as etapas do processo (lembremos do fotógrafo como o intérprete de seus negativos), o valor axiomático do movimento deve ser negado. Vemos aqui uma problematização da perspectiva realista descrita por Dulac, Bazin e Mitry.

Inicialmente, as duas posturas parecem mutuamente exclusivas. A cada argumento favorecendo a objetividade da fotografia, e a proeminência da realidade sobre a interpretação do artista, veríamos a transposição do mesmo tópico para o seu inverso, ou seja, a via subjetiva que coloca a própria interpretação como o fator determinante na construção da imagem fotográfica. A convergência parece ocorrer apenas na própria estrutura material da fotografia, em seu aparato e em suas condições básicas: tanto Bazin como Frampton concordam sobre os processos envolvidos; a diferença está na ênfase dada aos aspectos desses processos.

Devemos lembrar que ambos dão provas de reconhecer a polaridade fundamental da qual fazem parte, e das diferentes camadas em suas teorias. Sabemos que Bazin não faz a defesa estrita de um objeto completamente independente do sujeito, assim como Frampton não advoga por um sujeito completamente independente do objeto. A natureza - "tudo do outro lado da câmera" - é o objeto da fotografia, tanto para Bazin como para Frampton. Este objeto deve ser abstraído, transposto para as condições próprias do aparato, e o sujeito, na figura do fotógrafo (ambos concordam novamente) é o intérprete que realiza tal abstração, ou ainda, através do qual esta é realizada. ${ }^{66}$

${ }^{65}$ Cf. Frampton, "For a Metahistory of Film", in Jenkins, Op. cit., p. 137. Originalmente em Artforum, vol. $10, \mathrm{n}^{\circ} 1$, setembro de 1971 .

${ }^{66}$ Cf. Bazin, "O realismo cinematográfico e a escola italiana da Liberação", in Op. cit., pp. 291-292: "Mas o realismo em arte só poderia, é evidente, proceder de artifícios. Toda estética escolhe forçosamente entre o que vale ser salvo, perdido e recusado, mas, quando se propõe essencialmente, como faz o cinema, a criar a ilusão do real, tal escolha constitui sua contradição fundamental, a um só tempo inaceitável e necessária. Necessária, já que a arte só existe através dessa escolha. Sem ela, supondo que o cinema total fosse desde hoje tecnicamente possível, retornaríamos pura e 
A preferência de Bazin por um caminho que não se atenha apenas à superfície sensível, que busca a integração dos aspectos superficiais sob um princípio interno, é em parte herdada da noção de fotogenia, comum entre autores franceses dos anos 1920 (como Louis Delluc e Jean Epstein), para quem o termo designaria a poesia do próprio mundo. A função do cinema seria então

extrair dos objetos aquilo que sempre lhes pertenceu, mas permanece fora do alcance da percepção humana. A imagem cinematográfica produz um desnudamento, revela o "inconsciente secreto das atitudes", o "ritmo da natureza e seu movimento que nos emociona". ${ }^{67}$

Jacques Aumont comenta como a necessidade, na concepção realista, de desenvolver uma prática específica traz uma ambiguidade fundamental: para dizer algo sobre o real, e não apenas sobre a realidade momentânea, deve-se criar uma espécie de mundo imaginário, que produza o efeito de realidade ao mesmo tempo em que busca retomar uma característica ideal. Trata-se de elaborar, à parte do mundo real, algo que seja análogo a ele, mas para dele afirmar sua identidade. Essa ambiguidade retorna em sua definição de "forma":

\begin{abstract}
Na tradição estética, a forma coincide, a princípio, com a aparência. De um ponto de vista mais dinâmico, ela é, no mais das vezes, concebida como princípio de organização da expressão de uma obra. A "formatação" de um material é também uma das definições mais frequentes da atividade artística, em sua vertente criatorial: o espectador recebe, de sua parte, a obra como expressando, por meio de sua forma, um conteúdo. ${ }^{68}$
\end{abstract}

simplesmente à realidade. Inaceitável, já que ela se faz em definitivo à custa dessa realidade que o cinema se propõe a restituir integralmente." Ver também Frampton, "Meditations around Paul Strand", in Jenkins, Op. cit., p. 58. A dimensão documental, didática e objetiva da fotografia é exemplificada por Frampton em um diálogo com uma de suas alunas, em que ela diz ter se afastado da fotografia por cada vez mais ter a impressão de que "todas as fotografias estão começando a se parecer umas com as outras, como páginas de prosa num livro", e "como se todas elas tivessem sido tiradas pela mesma pessoa". Parece haver aqui a noção de um "livro da natureza", como no título do livro de Fox-Talbot - a noção de que o conjunto de aparências do mundo guardaria uma unidade subjacente da qual as fotografias dariam apenas pistas, e que mesmo a subjetividade de fotógrafos individuais não seria capaz de alterar.

67 Xavier, Op. cit., p. 95.

68 Jacques Aumont e Michel Marie, Dicionário Teórico e Crítico de Cinema (Campinas: Papirus, 2001), p. 134 e p. 253. A definição dessa oposição é uma das razões para que o termo "formalismo" tenha sido preferido no decorrer do texto para se referir à vertente representada por Frampton, em vez de "formativa" ou "criacionista". 
Vimos anteriormente que Bazin e Frampton fazem suas defesas tendo em vista a existência de um pólo complementar. Se o ponto de encontro é a própria estrutura do material, podemos considerar ainda que eles realizam uma espécie de direcionamento das energias envolvidas na formação deste material, para um ou outro pólo. A polaridade estabelece uma relação de interdependência entre os dois pontos, de modo que a ênfase nas características subjetivas tem como consequência a diminuição de suas características objetivas, e vice-versa; ao mesmo tempo, a própria definição de um lado é contingente à definição do outro. Bazin e Frampton propõem uma série de questionamentos voltados para direções opostas: sobre o que é objetivo ou subjetivo na fotografia; sobre o que é revelado com a diminuição ou neutralização dos aspectos objetivos ou subjetivos envolvidos na prática fotográfica; sobre quais obras surgem e o que elas demonstram através dessa ótica. Ambos estendem esse processo ao cinema.

Gaston Bachelard aborda uma oposição semelhante no pensamento científico, e sugere como hipótese de trabalho a determinação do substrato comum às duas tendências. A mediação do objeto pelo sujeito, ele argumenta, deve tomar a forma de um projeto. ${ }^{69}$ Considerando esta hipótese, devemos observar como os projetos de cinema de Bazin e de Frampton se adequam às mesmas condições: a observação dos caminhos que um mesmo substrato pode tomar, tendendo ao reforço da presença do objeto (as características objetivas como descritas por Bazin) ou do sujeito (as características subjetivas como descritas por Frampton). Para tanto, devemos investigar o que seria esse substrato comum. Devemos reconhecer o que é inevitável para cada um deles, o que depende de certas condições, e o que é reforçado ou preferido por maior adequação a um certo ideal.

69 Cf. Gaston Bachelard, O Novo Espírito Científico (Rio de Janeiro: Tempo Brasileiro, 1968), p. 18. 
III.

ELEMENTOS E MODOS DE ARTICULAÇÃO 


\section{A definição do cinematográfico pelo não-cinematográfico}

Os julgamentos de valor de Bazin e suas descrições da história do cinema se baseiam não apenas no que os filmes revelam do real, mas também em como é feita essa revelação. Como já foi comentado, ainda que o cinema total pareça ser para ele um ideal, acaba funcionando como um horizonte em seu pensamento, uma referência para suas abordagens mais específicas. A imagem deve ser enquadrada, projetada em uma superfície plana, restrita temporalmente, em sua gama de cores, e assim por diante. O cinema incorpora essas limitações, e é através dessa abstração do tempo e do espaço que os cineastas expressam uma atitude em relação à realidade. Disso resulta uma postura em relação às obras que consiste numa defesa dos procedimentos que lhe parecem mais voltados ao objetivo da representação.

A crítica de Bazin aos teóricos da montagem passa pela asserção de que o cinema é reduzido ao seu próprio aparato. Ele não é um modernista no sentido descrito por Greenberg. ${ }^{70}$ A natureza do cinema, em seu pensamento, não é tanto a de constituir algo em si, mas de se constituir em relação a algo externo, o que Philip Rosen interpreta como sendo uma definição do "cinematográfico" pelo "não-cinematográfico". Essa definição é exemplificada na relação do cinema com outras artes: o teatro ou a literatura não são vistos por ele como intervenções na pureza cinematográfica, mas como partes da história socioeconômica, e mesmo como parte dos materiais do cinema. ${ }^{71}$

Nesse sentido, Bazin se coloca contra os vanguardistas dos anos 1920. Nomes como Hans Richter, Walter Ruttmann e Oskar Fischinger buscaram avançar o cinema através do "puramente cinemático", criando obras que desenvolvem verdadeiras músicas visuais formadas por figuras geométricas que se movem, se alternam e se interpenetram ritmicamente. Richter se diz em busca das "leis próprias do movimento cinematográfico" que envolveriam mudanças de luz e sombra nos eixos horizontal e vertical, mudanças de escala, movimentos lento e rápido, contraste, aproximação,

70 Colin MacCabe dedica um ensaio à noção de que Bazin é um modernista, mas não no sentido considerado por Greenberg, para o qual não haveria um equivalente exato na crítica francesa anterior aos anos 50. Ver "Bazin as Modernist", in Andrew (ed.), Op. cit., pp. 66-76.

71 Cf. Philip Rosen, "Belief in Bazin", in Andrew, Opening Bazin, p. 111. 
interação. $^{72} \mathrm{O}$ avanço ocorreria, portanto, no que acreditavam serem as propriedades materiais únicas do cinema, ignorando seus aspectos comerciais. Esta é uma das razões para a discordância de Bazin: ele diz que tais obras não tiveram qualquer seguimento, e que, ao não se ater aos fatores comerciais e à origem narrativa da técnica cinematográfica, o filme de vanguarda acabou perdendo espaço. Sua defesa se volta para cineastas que buscaram o avanço dentro das condições estabelecidas, para que algo de fato ocupasse o terreno. Por esse critério, Jean Renoir é considerado um exemplo, alguém que "inova sem ignorar o tema e o comércio", um modelo de vanguarda participativa, afetando diretamente a história do cinema. ${ }^{73}$ Esse exemplo é importante por evidenciar o "filtro" que o pensamento de Bazin exerce sobre o cinema (e que veremos também em Frampton): a dedicação a uma série de filmes que preenchem alguns requisitos, enquanto outros são considerados como à parte do problema central na arte.

A definição do cinema pelo "não-cinematográfico" é feita através de comparações com a pintura, o teatro e a literatura. Bazin identifica em cada uma dessas artes um aspecto a ser desenvolvido pelo cinema. A proximidade de alguns elementos é posta em evidência, ao mesmo tempo em que suas divergências são traçadas, e os objetivos do cinema tornados mais claros.

\section{Cinema e pintura}

Sobre a relação entre a tela do cinema e o quadro da pintura, Bazin aponta algumas diferenças. No quadro, a moldura enfatiza o microcosmo pictórico, limitando-o ao mesmo tempo em que direciona a contemplação para seu interior. Parece haver aqui uma concordância com o comentário de Frampton sobre o gesto do pintor constituir uma "metáfora para a relação entre o criador e a realidade". A pintura, como Bazin lembra no ensaio da ontologia fotográfica, representa "um universo ideal" - calcado no real, mas com certa autonomia, pois independente de uma relação "ontológica" como aquela da fotografia; uma arte condizente com a descrição de Batteux e que trabalha

72 Hans Richter, "The Badly-Trained Sensibility", in P. Adams Sitney (ed.), The Avant-Garde Film, pp. 22-23.

73 Cf. Rosen, Op. cit., pp. 111-112. 
com a semelhança. Dessa forma, a pintura pode sugerir eventos e imagens fora de sua demarcação, mas estas permanecem secundárias, desdobramentos indiretos dos elementos apresentados e concentrados em seu interior. Na tela cinematográfica, a ontologia fotográfica seria um dos pontos de partida; logo, sempre haveria um “exterior", pois a abstração da tela representa uma espécie de "máscara da realidade", que se prolonga indefinidamente fora dela. A formulação de Bazin para dar conta dessas diferenças é a de que a moldura na pintura é centrípeta, enquanto a tela no cinema seria centrífuga. $^{74}$

Bazin cita algumas das críticas mais comuns aos filmes que utilizam quadros como pretextos. Uma delas diz que "a unidade dramática e lógica do filme estabelece cronologias ou vínculos fictícios entre obras por vezes muito afastadas no tempo e no espírito". Mesmo que os dados históricos sejam respeitados, o cineasta "basearia ainda seu trabalho numa operação esteticamente contra a natureza; ele analisa uma obra sintética por essência, destrói sua unidade e opera uma nova síntese que não é aquela desejada pelo pintor”. O fator mais profundo dessa traição seria a da realidade imediata da obra - não apenas a fidelidade à imagem (que, mesmo num filme colorido, Bazin nos diz, "não é absoluta”), mas ainda a inevitável reconstituição temporal. O tempo na pintura é em profundidade; como uma arte espacial, nos termos de Lessing, o tempo pictórico é "indireto", ou ainda sugerido pelo espaço, construído a partir das tensões e disposições espaciais. O tempo no cinema é horizontal; ele depende da apresentação ordenada de seus elementos, de modo que é a simultaneidade dos espaços que deve ser sugerida. $^{75}$

Ele complementa as críticas com o que diz ser a capacidade do cinema de não simplesmente apresentar as obras pictóricas, mas acrescentar a elas, e acima de tudo, constituir em si uma obra autônoma. Como exemplo, faz referência ao Van Gogh (1948) de Alain Resnais, cuja originalidade residiria

na abolição da moldura, cujo desaparecimento identifica o universo pictórico com o universo, simplesmente. Sem dúvida a câmera, uma vez "dentro" dos quadros, podia nos conduzir de acordo com uma determinada duração descritiva ou dramática; no entanto, a verdadeira novidade não era de ordem temporal, mas exclusivamente espacial. $\mathrm{O}$ olho também analisa e não se apressa, mas as

74 Cf. Bazin, "Pintura e cinema", in Op. cit., pp. 206-207.
75 Ibid., pp. 205-206. 
dimensões do quadro e suas fronteiras o fazem se lembrar da autonomia do microcosmo pictórico cristalizado para sempre fora do tempo. ${ }^{76}$

O uso positivo da pintura pelo cinema, portanto, deve passar pelas condições essenciais do cinema, ou ainda pela adaptação das condições da pintura ao cinema.

Um segundo exemplo, cuja originalidade se revela principalmente na relação entre o tempo de cada uma das artes, seria O Mistério de Picasso (Le Mystère Picasso, 1956), de Henri-Georges Clouzot, que mostra o artista executando uma série de desenhos sobre telas transparentes. A câmera testemunha a criação, a pontuação gradativa da superfície pictórica, e nesse desenvolvimento gradual é que, segundo Bazin, atingiria sua autonomia. Não se trata simplesmente do documento de uma obra pictórica, mas de uma obra cinematográfica que utiliza elementos pictóricos para compor um sentido próprio. O filme de Clouzot se baseia na construção do quadro, mas não é idêntico a ele; utiliza como elemento o peso temporal dessa composição, e não apenas a "duração da criação". Se o filme é sinônimo de algo, é do processo pictórico que resulta nos quadros de Picasso. Bazin identifica o suspense como o princípio central de condução dessa temporalidade: a constante tensão entre os elementos, fazendo com que a progressão não seja necessariamente dramática, mas numa chave mais livre, a metamorfose direta da duração através das formas visuais. ${ }^{77}$

\section{Cinema e teatro}

O teatro é visto como a principal referência para a relação entre a presença dos objetos (especialmente os atores), a experiência do espaço e a construção dramática como um todo. A “arte específica do drama” é uma influência praticamente inescapável para o cinema como pensado por Bazin. ${ }^{78}$

76 Bazin, "Um filme bergsoniano: Le Mystère Picasso", in Op. cit., p. 212. Originalmente em Cahiers du Cinéma, $\mathrm{n}^{\circ}$ 60, junho de 1965.

77 Ibid., pp. 214-215. Bazin comenta brevemente o que considera "a tradição mais interessante do desenho animado": nomes como Len Lye e Norman McLaren, que, segundo ele, realizariam a autonomia dessas formas abstratas, sem "justificá-las", concebendo apenas a transformação lógica do espaço. A animação parece ser considerada por ele como um ramo isolado da arte cinematográfica, quando não uma arte distinta.

78 Cf. Bazin, "Teatro e cinema", in Op. cit., pp. 160-163. 
Para marcar mais claramente as diferenças, Bazin comenta duas possibilidades de apropriação do teatro pelo cinema: a simples fotografia da peça (o "teatro filmado") e a adaptação da peça às exigências da arte cinematográfica. A primeira cria problemas semelhantes ao já citado uso da pintura, pela distância entre as condições que permitem a representação. Ele resume:

Se por cinema entende-se a liberdade de ação em relação ao espaço, e a liberdade do ponto de vista em relação à ação, levar para o cinema uma peça de teatro será dar a seu cenário o tamanho e a realidade que o palco materialmente não podia lhe oferecer. Será também liberar o espectador de sua poltrona e valorizar, pela mudança de plano, a interpretação do ator. Diante de tais misesen-scène, deve-se convir que todas as acusações contra o teatro filmado são válidas. Mas é que, precisamente, não se trata de mise-en-scène. A operação constituiu apenas em injetar, à força, o "cinema" no teatro. O drama original, e com muito mais razão o texto, encontram-se ali fatalmente deslocados. O tempo da ação teatral não é evidentemente o mesmo que o da tela, e a primazia dramática do verbo fica defasada pela dramatização adicional que a câmera dá ao cenário. Enfim, e sobretudo, uma certa artificialidade, uma transposição exagerada do cenário teatral é rigorosamente incompatível com o realismo congênito do cinema. ${ }^{79}$

Um ponto crucial que, para Bazin, separa o teatro do cinema, é que o primeiro está fundado na convenção, enquanto o segundo possui uma identidade com a natureza. Assim como o quadro da pintura era interpretado como espaço de representação de um universo ideal, aqui o cenário teatral é visto como um lugar circunscrito e que volta todas as aparências para seu próprio interior. Sua moldura, nesse caso, é sua própria arquitetura, que separa o público da cena, vista como "um microcosmo inserido à força no universo, mas essencialmente heterogêneo à natureza". ${ }^{80} \mathrm{O}$ mesmo termo utilizado para a pintura retorna para diferenciar a tela do palco:

É bem diferente o que acontece no cinema, cujo princípio é negar qualquer fronteira para a ação. O conceito de lugar dramático não é apenas estranho, mas essencialmente contraditório à noção de tela. A tela não é uma moldura, como a

\footnotetext{
79 Ibid., p. 164.

80 Ibid., pp. 181-182.
} 
do quadro, mas uma máscara que só deixa uma parte do evento ser percebida. Quando um personagem sai do campo da câmera, nós admitimos que ele escapa ao campo visual, mas ele continua a existir, idêntico a si mesmo, num outro ponto do cenário, que foi mascarado. A tela não tem bastidores, não poderia ter sem destruir sua ilusão específica, que é fazer de um revólver ou de um rosto o próprio centro do universo. Ao contrário do espaço do palco, o da tela é centrífugo. ${ }^{81}$

O fracasso do teatro filmado viria da inabilidade de reter a energia dramática em outro espaço - o da tela. Um problema de realismo, como Bazin exemplifica em sua crítica ao "caligarismo", que "quis substituir-se ao realismo do cenário sob a influência do teatro e da pintura". O realismo existe como um denominador comum entre a imagem cinematográfica e o mundo em que vivemos, o que passa por sua concepção espacial, essencialmente diferente daquelas da pintura ou teatro. Essa realidade do espaço, ele diz, é a única da qual não podemos desprover a imagem cinematográfica. ${ }^{82}$

A comparação com o teatro também reforça o que Bazin chama de um caráter anti-antropocêntrico do cinema. $O$ fato de depender da convenção faz com que o teatro só exista com o homem, o que pode ser dispensado pelo cinema. "Uma porta que bate, uma folha ao vento, ondas que lambem uma praia podem aceder à potência dramática". Tem importância decisiva na mise en scène o fato de que no cinema o drama vai do cenário ao homem (enquanto no teatro ele parte do homem). ${ }^{83}$

A construção do mundo dramático no teatro é feita pela presença efetiva dos atores, necessitando de uma abstração por parte do espectador. Essa presença não é o fim, mas o meio; ela deve ser transformada em um objeto imaginário, ainda que dela permaneça uma consciência recíproca por parte de ambos (ator e espectador). No cinema, por outro lado, "contemplamos solitários, escondidos num quarto escuro, através de persianas entreabertas, um espetáculo que nos ignora e que participa do universo". 84

É igualmente no que diz respeito à ontologia que a eficácia do cinema tem sua origem. É errôneo dizer que a tela é absolutamente impotente para nos colocar

\footnotetext{
Ibid., pp. 182-183.

Ibid., p. 185.

Ibid., p. 179.

84 Ibid.
} 
"em presença" do ator. Ele faz isso à maneira de um espelho (que, é ponto pacífico, substitui a presença do que se reflete nele), mas de um espelho com reflexo deferido, cujo aço retivesse a imagem. É verdade que, no teatro, Molière pode agonizar no palco e que temos o privilégio de viver no tempo biográfico do ator; assistimos, entretanto, no filme Sangue de toureiro [Brindis a Manolete, Florián Rey, 1948], à morte autêntica do célebre toureiro, e, se nossa emoção não é tão forte quanto se estivéssemos na arena naquele instante histórico, ela é, no entanto, da mesma natureza. Não reganhamos o que perdemos do testemunho direto graças à proximidade artificial que o aumento da câmera permite? Tudo se passa como se, no parâmetro Tempo-Espaço que define a presença, o cinema só nos restituísse efetivamente uma duração enfraquecida, diminuída, mas não reduzida a zero, enquanto que a multiplicação do fator espacial restabeleceria o equilíbrio da equação psicológica. ${ }^{85}$

\section{Cinema e literatura}

Bazin aplica a mesma lógica da adaptação à literatura. Ele reconhece, como nas comparações anteriores, dois tipos. No primeiro, os autores fornecem apenas

personagens e aventuras cuja expressão literária é em larga escala independente... [os personagens] já fazem parte de uma mitologia extrarromanesca, gozam, de certo modo, de uma existência autônoma, cuja obra original não passa de uma manifestação acidental e quase supérflua. ${ }^{86}$

No segundo, o cineasta reconhece a identidade da obra como um dado, e sua transcendência como o objetivo da transposição para o cinema. Esta obra viria

de uma forma tão evoluída de literatura que os heróis e a significação de seus atos dependem intimamente do estilo do escritor, a partir do momento em que estão confinados como que num microcosmo cujas leis, rigorosamente necessárias, deixam de vigorar no exterior, a partir do momento em que o

85 Ibid., pp. 174-175.

86 Bazin, "Por um cinema impuro", in Op. cit., p. 113. 
romance abandonou a simplificação épica, e já não é uma matriz de mitos, mas o lugar de interferências sutis entre o estilo, a psicologia, a moral e a metafísica $\left[\ldots . . .{ }^{87}\right.$

O primeiro tipo corresponde ao teatro filmado, enquanto o segundo corresponde à adaptação das exigências da obra teatral às do cinema. A adaptação, nesse sentido, não trai a obra original, mas a respeita em sua autonomia, e através desse respeito constitui sua autonomia propriamente cinematográfica.

Como se daria a adaptação do romance para o cinema, visto que uma obra literária não apenas não é constituída de imagens concretas como a pintura, como nem ao menos elabora uma representação estritamente ligada a uma configuração espacial e gestual como no teatro? Uma característica comum, ressaltada por Bazin, é o uso da narrativa. Tanto o romance como o cinema são artes que se desenrolam no tempo, e que sugerem, nesse processo, "um mundo real". ${ }^{88}$ Mas se por um lado a literatura e o cinema compartilham esse fator, por outro as condições específicas da literatura devem ser transpostas para outro nível. O fato de a imagem cinematográfica evocar diretamente essa realidade (enquanto o romance deve criá-la no leitor) é sugerido como um ponto positivo de uma arte sobre a outra, ao mesmo tempo em que marca uma diferença fundamental entre elas.

Hugh Kenner define o romance como uma obra longa em prosa que deve preencher dois requisitos. Ela deve, primeiramente, ser verossímil, isto é, dar conta, através de palavras, de objetos familiares ao leitor, em orações que descrevam comportamentos ou diálogos reconhecíveis. E também deve ser plausível, isto é, a progressão de eventos deve satisfazer critérios racionais, justificando as ações dentro da lógica narrativa. Kenner aponta duas vertentes de romance, reconhecendo duas unidades passíveis de articulação, e que teriam a preferência de cada um dos grupos. Para uma das vertentes, a unidade básica é a oração: como exemplos, ele cita Flaubert, Joyce e Beckett, que consideram as orações como disposições de palavras, e os romances como disposições de signos sobre as páginas. No outro grupo, a unidade básica é o evento: Dostoiévski, Tolstói e Lawrence, para quem os personagens não são produtos de combinações de palavras, mas "energias". Enquanto o primeiro grupo tenderia para o que Kenner descreve como uma obsessão com a ordem precisa das palavras (Flaubert

$87 \quad$ Ibid., p. 114

88 Ibid., pp. 153-154. 
dedicando dias à escolha de uma única palavra; Joyce testando combinações das mesmas palavras numa frase), também caminharia na direção de uma representação cada vez menos realista. Em outras palavras, a ênfase no caráter puramente textual em detrimento de referências externas tornaria a ficção gradualmente mais rarefeita dentro do sistema autônomo do romance. ${ }^{89}$

Uma comparação superficial entre as concepções de Kenner e Bazin pode sugerir uma preferência deste último pelos autores que articulam eventos, ao invés de orações. Sua crítica aos teóricos da montagem, afinal, passa pelo fato de identificarem a arte cinematográfica com seu próprio aparato; a manipulação direta de palavras, especialmente como signos dispostos sobre as páginas, parece um empreendimento modernista de nível semelhante. Mas a questão, mais uma vez, se resolve na ontologia, e a literatura não possui a mesma ligação objetiva com a realidade sensível que o cinema. Se por um lado Bazin não demonstra uma preferência pelos primeiros autores citados por Kenner (apesar de, como veremos adiante, Bazin reconhecer uma influência do modernismo literário em alguns dos filmes que defende), por outro, ele entende que a base fotográfica do cinema não o restringe à "dialética das aparências":

Se é verdade que [a fotografia] só pode apreender seu objeto do exterior, há mil maneiras de agir sobre sua aparência para eliminar qualquer equívoco e fazer dela o signo de uma, e apenas uma, realidade interior. Na verdade, as imagens da tela são, em sua imensa maioria, implicitamente de acordo com a psicologia do teatro ou do romance de análise clássica. Elas supõem, junto com o senso comum, uma relação de causalidade necessária e sem ambiguidade entre os sentimentos e suas manifestações; postulam que tudo está na consciência e que a consciência pode ser conhecida. ${ }^{90}$

89 Ver o prefácio de Kenner, Flaubert, Joyce, Beckett: The Stoic Comedians (Toronto: Beacon Press, 1962).

90 Bazin, "Por um cinema impuro", Op. cit., p. 122. 


\section{A psicologia da narrativa}

Podemos, a partir da última citação, nos voltar para artistas que Bazin reconhece como marcantes no progresso do realismo no cinema. Ele nos diz que tanto Orson Welles como Roberto Rossellini efetuam mudanças importantes na técnica da narrativa, através de um movimento contrário à tendência analítica da decupagem clássica. Esta, definida por Bazin a partir de Griffith, consiste na sequência de pontos de vista, lógicos ou subjetivos, sobre um acontecimento, decompondo a realidade e introduzindo nela uma abstração até então inexistente - o que podemos resumir como sua atenção à presença da montagem como uma abstração artificial ou arbitrária. ${ }^{91}$

Implícita nesta definição está a noção de que esse acontecimento é um fato, que perde sua condição "total" ao ser transposto para o cinema - a abstração inevitável. Na decupagem clássica "o fato é atacado pela câmera, dividido, analisado, reconstituído", ou seja, tem sua unidade dispersa. Isso não faz com que ele perca toda a sua qualidade factual, mas "esta fica revestida de abstração como a argila de um tijolo pela parede ainda ausente que multiplicará seu paralelepípedo". ${ }^{92}$

Bazin defende que o avanço realizado por Welles em Cidadão Kane (Citizen Kane, 1941) envolve o uso do plano-sequência, que estende tanto a continuidade como a profundidade de campo (através do uso da lente grande-angular), e representa a cena como um todo no tempo e no espaço. A decupagem tradicional é vista como uma perda de eficiência nesse sentido. A escolha de Welles é mais realista, pois mais ambígua; por restituir ao espectador a liberdade de deduzir relações implícitas sem que a câmera guie sua atenção (portanto, sem defini-la a priori), ela seria, então, mais realista em três aspectos: ontológico, dramático e psicológico. ${ }^{93}$

A influência do expressionismo em Kane é um aspecto que, em princípio, faria Bazin recuar em sua defesa. Os jogos de luz e espelhos que multiplicam as referências espaciais, bem como o caráter barroco dos ornamentos, também multiplicados à exaustão em alguns momentos, não constituem elementos pontuais, mas constantemente presentes na encenação. $\mathrm{O}$ mesmo poderia ser dito da estrutura narrativa, baseada em diversas camadas temporais sobrepostas, quando não confundidas pela montagem. Mas

\footnotetext{
91 Cf. Bazin, "O realismo cinematográfico e a escola italiana da Liberação", in Op. cit., p. 293.

92 Ibid., p. 301.

93 Cf. Bazin, Orson Welles (Rio de Janeiro: Jorge Zahar, 1998), pp. 83-84 e pp. 91-92.
} 
é a unidade psicológica alcançada por Welles que Bazin ressalta, e que remete à sua defesa de um tipo de romance moderno cuja exploração reduzida de aspectos gramaticais teria revelado a "essência secreta do estilo":

Certas qualidades da língua de Faulkner, Hemingway ou de Malraux com certeza não poderiam entrar numa tradução, porém, o essencial do estilo deles nada sofre com isso, pois neles "o estilo" se identifica quase que totalmente com a técnica da narrativa. Ele não é senão a colocação no tempo de fragmentos de realidade. O estilo torna-se a dinâmica interna da narrativa, é um pouco como a energia em relação à matéria, ou, se quisermos, como a física específica da obra; é ele quem dispõe uma realidade fragmentada sobre o espectro estético da narrativa, quem polariza a limalha dos fatos sem modificar a composição química deles. ${ }^{94}$

Como na defesa que Dulac empreende da continuidade do movimento, Bazin entende que é necessária uma manutenção da "voltagem da cena". É preciso que ela permaneça isolada de qualquer "contato parasitário" para que a ação se direcione naturalmente. Ele reconhece uma concentração ainda maior dessa estratégia em Soberba (The Magnificent Ambersons, 1942), filme seguinte de Welles. Comparado com Kane, Soberba é um filme mais sóbrio, tanto no nível estrutural como na abordagem psicológica dos personagens; em lugar da multiplicidade de perspectivas circundando a esfinge que é o protagonista de sua primeira obra, Welles opta aqui por uma observação quase romanesca do universo. A trama gira em torno de George (Tim Holt), herdeiro de uma família rica na virada para o século XX, e de seu conflito com Eugene (Joseph Cotten), fabricante de automóveis que corteja sua mãe viúva. O apego excessivo de George à mãe se cruza com o ciúme de sua tia Fanny (Agnes Moorehead), apaixonada por Eugene. Uma cena crucial, por sua duração e pelo encontro das duas trajetórias e intenções, é o diálogo entre George e Fanny na cozinha; ao comentá-la, Bazin aponta a importância da escolha pelo plano sequência em profundidade:

Se a intenção era a todo instante jogar com a unidade significativa da cena, construir a ação não sobre uma análise lógica das relações entre os personagens e seu meio, mas sobre a percepção física dessas relações como forças

94 Bazin, "O realismo cinematográfico e a escola italiana da Liberação", Op. cit., p. 296. 
dramáticas, nos fazer assistir à sua evolução até o momento em que a cena inteira explode sob essa pressão acumulada, convinha necessariamente que o âmbito da tela pudesse revelar a totalidade da cena. ${ }^{95}$

O respeito ao realismo da cena torna-se sinônimo do respeito pela dinâmica interna da narrativa. A unidade de espaço e tempo é o pré-requisito para que a cena se torne a própria matéria a ser dinamizada pela condução do cineasta. Não em uma determinação externa, mas pela revelação das características internas de seus elementos.

Essa preferência pela não-determinação a priori do sentido é um dos pontos que Bazin enfatiza no cinema de Rossellini, para quem a unidade da narrativa não seria o plano, mas o próprio fato:

Fragmento de realidade bruta, por si só múltiplo e equívoco, cujo "sentido" sobressai somente a posteriori, graças a outros "fatos", entre os quais a mente estabelece relações. Sem dúvida o diretor escolheu esses "fatos", mas respeitando sua integridade de "fato". 96

Sobre esse trabalho de imaginação requerido para estabelecer relações entre os fatos, André Labarthe comenta:

É essa ditadura do espírito sobre os fatos, pela qual nasce um sentido, que Bazin chama de realismo. O realismo não consiste, na verdade, em "acrescentar mais realidade à obra", porque "esse suplemento de realidade é somente um meio mais ou menos eficaz - de servir a um propósito perfeitamente abstrato: dramático, moral ou ideológico"; mas trata-se, ao contrário, de expulsar qualquer traço de ideologia de uma noção que "só conhece a imanência". 97

Ainda que pela descrição de Labarthe pareça que Bazin entregue a primazia do sentido à consciência do espectador, ele logo complementa, retornando à natureza factual da própria imagem e ao termo utilizado para diferenciar a tela do quadro e do palco: o que possibilita a relação da imagem com a natureza são as "propriedades

\footnotetext{
95 Bazin, Orson Welles, pp. 84-85.

96 Bazin, "O realismo cinematográfico e a escola italiana da Liberação", Op. cit., p. 303.

97 Ver a introdução de Labarthe em Bazin, Orson Welles, p. 10.
} 
centrífugas" da tela cinematográfica, que permitem a constituição da narrativa. ${ }^{98}$ É a realidade, estendida para além dos limites do cinema, que permite a conjugação de diferentes fatos, bem como seu direcionamento em uma narrativa.

Ele retoma também a metáfora dos tijolos para descrever o plano como elemento da decupagem analítica. A utilidade do tijolo é definida de antemão, de modo que a casa ou ponte que será o resultado da combinação de sucessivos tijolos prescreve a própria forma de cada elemento particular. A contraparte, identificada com o neorrealismo, seria a metáfora das pedras dispersas num rio: mantendo sua realidade de rochas, e como tais, elas também servem para realizar uma travessia. O universo de Rossellini, nesse sentido, é um universo de "atos puros, insignificantes neles mesmos". Seu respeito pela realidade não consiste apenas no acúmulo de aparências, mas no despojamento do que não é essencial. Bazin argumenta que essa é a maneira de alcançar a totalidade dentro da simplicidade. ${ }^{99}$ É essa pureza e insignificância das ações que prepara a revelação do real.

Tomemos como exemplo Viagem à Itália (Viaggio in Italia, 1954). A relação de Alex (George Sanders) e Katherine (Ingrid Bergman) é catalisada pelos espaços que eles atravessam: longe do conforto britânico, ambos confrontam uma paisagem bruta e repleta de ruínas, com uma dimensão - tanto puramente espacial como em profundidade histórica - que revela sua alienação, da qual a crise no relacionamento é a expressão mais flagrante. Tag Gallagher descreve essa abordagem como "a imposição do espaço". O filme de Rossellini nos impõe essa geografia, a luminosidade, a textura mineral de Nápoles e seus arredores; da mesma forma, a consciência dos personagens é a cada cena atraída para tais elementos, definida e realimentada por eles, como na cena em que veem serem escavados os corpos calcinados de um casal em Pompeia. ${ }^{100} \mathrm{O}$ interior é sugerido através do exterior, em seus aspectos mais superficiais. A validade ontológica dessa realidade é o que garante que ela seja o reflexo da realidade interior, e consequentemente garante a unidade da composição a partir da lei biológica da narrativa.

Ao final do filme, George e Katherine atingem o que parece ser o ponto de tensão máxima, a completa resignação dentro da crise amorosa, até que, durante uma

98 Bazin, Ibid. Ver também "Alemanha Ano Zero", in Op. cit., p. 222: "Não é esta uma sólida definição do realismo em arte: obrigar o espírito a tomar partido sem trapacear com os seres e as coisas?"

99 Bazin, "Defesa de Rossellini", in Op. cit., p. 371.

100 Cf. Tag Gallagher, "Roberto Rossellini and Historical Neorealism", in Artforum, no 10, verão de 1975, p. 42. 
procissão religiosa, Katherine é carregada pela multidão, se afastando de George, que atravessa o mar de pessoas para socorrê-la. Esse reencontro, ainda que breve, é dimensionado por Rossellini por sua integração ao espaço, afastando a câmera dos protagonistas, revelando os movimentos das pessoas imersas no êxtase religioso: é no centro desse cenário que o casal se reaproxima, e que sua tensão é sublimada tanto no abraço final como na elevação da câmera sobre a procissão. Sobre o "milagre" da cena, Bazin reforça que ele é

invisível para os dois heróis, quase invisível até mesmo para a câmera, e aliás ambíguo (pois Rossellini não pretende que seja um milagre, mas apenas o conjunto de gritos e empurrões que é assim chamado), mas cujo choque contra a consciência dos personagens provoca inesperadamente a precipitação de seu amor. $^{101}$

Essa coesão entre a psicologia da narrativa e da superfície bruta da matéria, entre a maneira de apresentação dos eventos e sua necessidade interna, é o que Bazin reconhece como fundamental no método de Rossellini, sua capacidade de manter a unidade relativa dos fatos e de "encenar acontecimentos com uma estrutura estética mais dura, mais íntegra", na qual é menos possível discernir outra coisa que não o próprio acontecimento. Rossellini não articula os eventos para redirecioná-los a algo que ele próprio estabeleceu minuciosamente; ele os apresenta, e o rigor de seu método é sinônimo de seu esforço para que essa apresentação se dê com o máximo de transparência. $^{102}$

O mesmo ocorre em Stromboli (1950), o filme anterior de Rossellini com Ingrid Bergman. Ela interpreta Karin, uma lituana que se casa com um pescador italiano para deixar um campo de concentração. O casal vai morar numa aldeia aos pés do vulcão Stromboli, numa ilha mediterrânea; a terra erma e a hostilidade dos outros em relação ao fato de Karin ser estrangeira fazem com que ela se sinta constantemente incomodada, ao ponto de tentar escapar da ilha. Na parte final do filme, Karin foge pelas montanhas, mas logo se perde, sua visão confusa pela da fumaça do vulcão. Neste ponto, o espectador vê tão pouco quanto ela: a câmera mostra a personagem vagando e tossindo por entre as nuvens de fumaça que cobrem a tela. Quando ela finalmente chega à área 
mais visível da montanha, a operação se inverte: nós a vemos caminhar em direção ao topo, mas a câmera a acompanha lentamente, revelando o que ela vê apenas quando ela já se encontra de costas para a câmera - deste modo, só vemos a paisagem quando Karin pára a caminhada para contemplá-la; enquanto ela anda, enquanto há uma ação física, Rossellini se atém a isto.

Quando a protagonista, derrotada pelo cansaço, desaba no chão e clama por Deus, Rossellini corta para o que ela confronta: a figura massiva do vulcão, cobrindo toda a área visível com sua fumaça. Em seguida, corta para um close de Karin. O filme termina com ela pedindo desesperadamente que Deus a ajude, enquanto a câmera mostra a paisagem que a envolve. Há aqui uma relação estreita com a conclusão de Viagem à Itália. O drama de Karin, até então visto na escala humana da comunidade da ilha, é levado para uma escala cósmica conforme ela se afasta de casa. O vulcão é um elemento da natureza, algo que sempre esteve na ilha, desde a chegada de Karin, desde séculos antes de seu nascimento. O papel do espaço, e do vulcão como uma espécie de personificação, como um ente que parece influenciar o trajeto da personagem, é parte do que Bazin elogia em Rossellini: essa capacidade de tornar as coisas, como elas são, agentes de um mesmo movimento, que passa pelo homem, que é apreendido pelo espectador, mas que não deixa de sugerir, a cada momento, uma adequação a algo que se estende indefinidamente para além desses aspectos.

Sobre A Regra do Jogo (La Règle du jeu, 1939), de Jean Renoir, Bazin faz um comentário semelhante, quando se refere à importância dada por Renoir aos atores, à manifestação expressiva da presença e da interação deles num mesmo espaço, e como isso faz a narrativa praticamente florescer como um resultado natural dessas interações. O filme é célebre pelo uso extensivo de planos-sequência, pela profundidade de campo na construção das cenas, e pelo número de personagens cujos caminhos se cruzam durante uma festa numa mansão no campo. Se na cena de Soberba toda a atenção era voltada para dois personagens, numa concentração da "energia cênica", em A Regra do Jogo a atenção é constantemente dispersa em coreografias pelo espaço da mansão. Esse espaço é respeitado pela câmera de tal forma que ela parece repetir a dinâmica das interações dos personagens; a câmera não é mais rápida ou mais livre que nenhum deles, de modo que, durante uma cena em que ela chega ao canto de um cômodo, deve observar o resto da cena deste ponto. 
A manutenção da continuidade pelos longos planos que passeiam pela mansão faz com que vejamos um diálogo entre dois personagens ser interrompido por um terceiro, que por sua vez se afasta, mas permanece visível no fundo, enquanto um quarto surge de uma das portas, e assim por diante. É no jogo entre os olhares e movimentos sutis que grande parte das relações entre os personagens é desenvolvida, como eventos menores formando as constelações no céu que é o evento mais amplo compreendido por toda a cena. Bazin descreve a abordagem de Renoir como o convite para um jogo entre o espectador e os envolvidos na filmagem: sem um olhar atento, sem uma disposição a entrar na cena e se entregar às complexidades de cada comportamento representado, não seríamos capazes de absorver a riqueza da obra. ${ }^{103}$

A personalidade de cada personagem é formada por suas ações: são elas que revelam seu caráter. Bazin se refere aos momentos em que tudo parece cair em seu lugar e que cada ator se torna a encarnação perfeita de seu personagem através da "verdade que ilumina seus rostos". Nesse sentido, o respeito às necessidades internas da narrativa é levado a um extremo, pois é como se o sentido da existência de cada ator, sua presença física, fosse reconhecida através de uma força interior, a mesma que os leva a interagir e definir as curvas da cena, que por sua vez definem as curvas da narrativa, como um carrossel de temas que, em vez de determinar a posição de cada um em sua estrutura, é, ao contrário, formado por eles, em movimento constante. ${ }^{104}$

É importante entender a crítica de Bazin à montagem. Ela não toma a forma de uma negação a priori. O que Bazin efetua a cada análise é uma tentativa de respeitar a integridade de sentido na realidade factual de cada objeto. Partindo de suas noções ontológicas, e da continuidade espacial, é uma decorrência lógica que ele dê mais valor aos procedimentos que minimizem a criação abstrata de sentido. Em outras palavras, que ele seja contrário ao sentido que surge de fora, e não da realidade interior dos

103 Cf. Bazin in François Truffaut (ed.), Jean Renoir by André Bazin (Londres e Nova York: Howard \& Wyndham, 1974), p. 77. Jean-Claude Brisseau atenta para o fato de que os personagens não são sinceros uns com os outros, de modo que, se há uma verdade no filme, ela está além do comportamento consciente de cada um deles: está na relação entre o que um personagem expressa, o que revela de sua interioridade, e como a câmera observa isso no contexto da cena, em relação aos outros personagens, que se encontram na mesma situação. Ver "La Règle du jeu", in Cahiers du Cinéma, no 482, jul/ago de 1994, pp. 68-69.

104 Idem, p. 80. A cena da "máquina de música" ganha assim um novo sentido, pois é o momento em que os próprios personagens observam o que seria o oposto do cenário conduzido por Renoir: um microcosmo determinado em sua totalidade por meios mecânicos. 
fatos. ${ }^{105}$ Sua defesa de Cidadão Kane é exemplar nesse sentido: um filme cuja montagem se faz presente em diversos momentos, mas cuja unidade geral é definida pela ordem da narrativa, em que os cortes constituem apenas as arestas do que Bazin identifica como o estilo de Welles.

Bazin reconhece na montagem a projeção de estados de alma a partir de semelhanças exteriores - por isso o "efeito Kuleshov" é visto como o paradigma da montagem. Estabelecemos relações entre o que é visto em um momento, e o que é visto em outro, e dessa forma nos mantemos em uma realidade à parte daquela espacial e concretamente disposta pelos planos (o que Bazin chama de uma "irrealidade necessária”). A unidade fotográfica do espaço é o que ele considera de mais próximo de uma "especificidade cinematográfica", e nesse sentido a montagem é vista como um procedimento anticinematográfico, pois cria um relato artificial através de imagens. ${ }^{106}$

Sobre a necessidade inevitável da articulação de planos para a construção da narrativa, ele diz:

O importante é que possamos dizer, ao mesmo tempo, que a matéria-prima do filme é autêntica e que, no entanto, "é cinema". Assim, a tela reproduz o fluxo e refluxo de nossa imaginação, que se nutre da realidade à qual ela planeja se substituir; a fábula nasce da experiência que ela transcende. Mas reciprocamente, é preciso que o que é imaginário tenha na tela a densidade espacial do real. A montagem só pode ser utilizada aí dentro de limites precisos, sob pena de atentar contra a própria ontologia da fábula cinematográfica. ${ }^{107}$

E, num resumo de seu posicionamento, formula uma lei estética: “Quando o essencial de um acontecimento depende de uma presença simultânea de dois ou mais fatores da ação, a montagem fica proibida. Ela retoma seus direitos a cada vez que o sentido da ação não depende mais da contiguidade física, mesmo se ela é implicada". ${ }^{108}$

\footnotetext{
${ }^{105}$ Bazin, "A montagem proibida”, in Op. cit., pp. 83-85. Originalmente em Cahiers du Cinéma, no 65, dezembro de 1956.

106 Ibid., pp. 88-89.

107 Ibid., p. 90.

${ }^{108}$ Ibid., p. 92.
} 


\section{A definição da subestrutura axiomática do cinema}

As definições de Frampton, como esperado, tomam um caminho inverso ao de Bazin. Assim como a quase totalidade de suas referências modernistas em outras artes, Frampton concorda com a postura descrita por Greenberg. A busca pela demonstração do que seria único a cada arte, quais efeitos e operações limitam suas atuações, bem como constituem seus terrenos particulares, surge em decorrência da intensa crítica modernista aos meios de representação, em especial à predominância do "ilusionismo". Essa busca converge numa preferência pela superfície das obras (literalmente, no caso da pintura; metaforicamente, no caso da literatura ou da música), que também pode ser vista como uma ênfase na opacidade dos materiais, na contramão da defesa da transparência empreendida por grande parte dos partidários da arte clássica.

Frampton comenta algumas das tentativas de autodefinição por algumas artes: a já citada estratégia de deslocamento realizada por Borges, Beckett e Robbe Grilllet, que reduz o fluxo causal da ficção literária; a identificação dos parâmetros cromáticos e superficiais como os alvos de intervenção direta por pintores como Frank Stella, em detrimento da ilusão de profundidade; a delimitação das fronteiras da música (enunciação temática e cadência) através do método serial de Schoenberg e Webern. Todas essas tentativas viriam da mesma aspiração que ele atribui a Weston e Strand, o reconhecimento dos axiomas, ou condições inevitáveis de cada arte.

Ao se perguntar quais as condições básicas do cinema, ele faz questão de lembrar que estas devem ser "totalmente redundantes", isto é, devem estar presentes em absolutamente todos os filmes. Ele então sugere que três dessas condições seriam $o$ quadro, a plausibilidade da ilusão fotográfica e a narrativa. ${ }^{109}$

\section{O quadro}

Por "quadro", Frampton se refere ao limite físico que a imagem projetada na tela compartilha com seu correlato na faixa de filme, o fotograma, e que, "pelo acúmulo de

\footnotetext{
${ }^{109}$ Frampton, “A Pentagram for Conjuring the Narrative”, in Jenkins, Op. cit., p. 63.
} 
ilusões que passaram por seus limites, ganhou a força de uma metáfora para a consciência”. Ele reforça ao mesmo tempo a condição material e metafórica do quadro, propondo uma visão autorreferente do aparato cinematográfico:

As coisas encontram suas verdadeiras formas mais prontamente quando olham para si mesmas. O filme, olhando para si mesmo como a máquina total que é o cinema, refotografa e reprojeta sua própria imagem, simplesmente reiterando à infinidade imodificada seu retângulo radiante, afirmando com perfeita redundância seu limite, ou perímetro, que se tornou para nós, habitantes da cultura fílmica, um ícone da fronteira entre o conhecido e o desconhecido, o visto e o não-visto, o que está presente à consciência e o que está em absolutamente todos os outros lugares e é... inimaginável. ${ }^{110}$

Em outra descrição da projeção, ele nos lembra que o "mínimo" que podemos ver no cinema é uma tela completamente branca - um filme transparente, fazendo com que a luz do projetor atinja diretamente a tela branca. Um filtro vermelho, por exemplo, subtrai dessa luz as frequências correspondentes às cores verde e azul, fazendo com que vejamos o quadro avermelhado. A articulação do quadro é então definida como a decisão do que colocar frente ao projetor para que a imagem seja "modulada". ${ }^{111}$ Essa modulação pode eventualmente, mas não necessariamente, incluir a presença de figuras reconhecíveis; o ajuste do quadro (suas proporções, contrastes, etc.) envolve os diferentes parâmetros que, como na fotografia, definem a percepção do espectador de acordo com a sensibilidade do artista.

\section{A plausibilidade da ilusão fotográfica}

A expressão "plausibilidade da ilusão fotográfica" é o que Frampton chama de "um reflexo automático que triangula a distância entre a imagem projetada e uma 'norma imaginária'; um processo que depende da suposição ontogenética de que cada fotografia

\footnotetext{
${ }^{110}$ Frampton, "The Withering Away of the State of the Art", in Jenkins, Op. cit., p. 264.

111 Frampton, “A Lecture”, in Jenkins, Op. cit., pp. 125-127.
} 
implica um fenômeno concreto, e vice-versa". ${ }^{112}$ Numa primeira leitura, esta parece ser uma formulação idêntica à de Bazin. Mas, como vimos, o campo considerado por Frampton é distinto, pois ele parte do princípio de que qualquer traçado feito pela luz sobre o material sensível - com ou sem câmera, focado ou não por uma lente - é uma imagem fotográfica, e também que esta pode ser "interpretada" na impressão.

É importante ressaltar que Frampton coloca a "ontologia fotográfica" (que, ele insiste, não é a simples re-apresentação dos fenômenos) ao lado da articulação de seus elementos, o que no cinema resulta na negação da ilusão do espaço em profundidade como inevitável. Em outras palavras, a "ilusão fotográfica" não é sinônima de "ilusão em profundidade", o que significa que a "plausibilidade" citada por Frampton não é sinônima do "efeito psicológico" citado por Bazin. Ele usa a obra de Paul Sharits como um exemplo de cineasta inteiramente dedicado a esta crítica, e à asserção de que a representação realista nada mais é que uma gramática particular. Sharits vê o cinema como um "sistema de informações", e a teoria cinematográfica como uma taxonomia de seus elementos concretos, não de suas intenções. ${ }^{113}$ A concretude dos elementos, nesse caso, não é a dos eventos em sua relação física criada pelo processo fotográfico, mas da própria faixa de filme. Um filme de Sharits que representa diretamente essa preocupação é Tails (1976), em que ele registra a passagem de uma película em diferentes velocidades. Vemos, portanto, os furos pelos quais a faixa de filme é carregada no projetor, os flares e as marcas em sua superfície, e a passagem entre diferentes fotogramas, que normalmente seria dissolvida na projeção. Tanto Frampton como Sharits sugerem que a faixa de filme é uma espécie de notação criada pelo cineasta, a organização e ordenação de imagens e sons, fisicamente dispostos sobre uma mesma estrutura.

Annette Michelson comenta a oposição realizada pela vanguarda americana dos anos 60 e 70 (da qual Frampton e Sharits fazem parte) à concepção realista do cinema, empregando uma citação de Adorno:

O processo fotográfico do cinema, primordialmente representacional, coloca uma maior significância intrínseca no objeto, indiferente mais à subjetividade que às técnicas esteticamente autônomas; esse é o aspecto atrasado do cinema no processo histórico das artes. Mesmo quando o filme se dissolve e modifica

\footnotetext{
112 Frampton, “A Pentagram for Conjuring the Narrative”, in Jenkins, Op. cit., p. 143.

113 Cf. Paul Sharits, "From 'Words per Page"”, in P. Adams Sitney, The Avant-Garde Film, p. 261.
} 
seus objetos o quanto pode, essa desintegração nunca é completa. Consequentemente, [o cinema] não permite a construção absoluta: seus elementos, independente de quão abstratos, sempre retêm algo de representacional; eles nunca são valores puramente estéticos. ${ }^{114}$

Em seguida, ela reforça que o projeto teórico de nomes como Brakhage, Kubelka, Snow, Landow, Gehr e Jacobs "é mais claramente entendido como direcionado à destruição dessas suposições, canonicamente recebidas e estabelecidas". O que veríamos nos filmes e textos desses cineastas seriam diversos métodos de ataque, através "dos processos e propriedades fílmicos (grão, luz, emulsão...)" e da "insistente interceptação e bloqueio da continuidade diegética". ${ }^{115}$

Frampton reconhece Ernie Gehr como um cineasta preocupado com a dimensão física da luz, com a própria radiação luminosa do aparato cinematográfico como elemento formador. Se todo o cinema é "sobre a luz" - sobre modos de articulação da luz no tempo -, a obra de Gehr é a projeção de sua sensibilidade sobre essa qualidade absoluta. Em seus filmes, segundo Frampton, há uma ênfase no fato de que a luz está $n a$ imagem, que a imagem é constituída por essa luminosidade. ${ }^{116} \mathrm{O}$ próprio Gehr reforça essa interpretação em sua definição da imagem e do plano:

Um fotograma tem a ver com uma intensidade particular de luz, uma imagem, uma composição congelada no tempo e no espaço. Um plano tem a ver com a intensidade variável da luz, um balanço interno de tempo dependente do movimento intermitente e um movimento dentro de um determinado espaço dependente da persistência da visão. ${ }^{117}$

\section{A narrativa}

A inclusão da narrativa como uma condição inevitável do cinema inicialmente parece um contrasenso, visto a dedicação de Frampton ao projeto modernista. Mas veremos

\footnotetext{
114 Theodor Adorno apud Annette Michelson, "Frampton's Sieve", in October, n 32, primavera de 1985, p. 158.

115 Michelson, Id.

${ }^{116}$ Frampton, "Notes on Filmmakers", in Jenkins, Op. cit., p. 190.

${ }^{117}$ Ernie Gehr, "Program notes by Ernie Gehr", in Film Culture, no 53-55, primavera de 1972, pp. 36-7.
} 
que sua elaboração do termo é bastante heterodoxa, e que o uso da "narrativa" talvez seja mais uma provocação de sua parte do que uma defesa propriamente dita do termo em seu uso corrente.

Ele começa citando um diálogo com Stan Brakhage, que, "colocando a máscara de advogado do diabo", teria proposto a narrativa como um dos axiomas do cinema. Frampton então tenta descrever o posicionamento de Brakhage em suas próprias palavras:

TEOREMA DE BRAKHAGE: Para cada série finita de planos [“filme"] existe em tempo real uma narrativa racional de modo que cada termo na série, junto com sua posição, duração, partição e referência, pode ser perfeita e inteiramente determinada. ${ }^{118}$

Ele segue com a metáfora matemática num exemplo que funcionaria como uma prova do teorema. Ele cita a equação

$$
p=30
$$

e sua expansão

$$
p=\frac{p}{3}+\frac{p}{5}+\frac{p}{6}+\frac{p}{10}+6
$$

como algo que pode ser determinado pela seguinte narrativa: "Um colar se quebra durante um conflito amoroso. Um terço das pérolas caiu no chão, um quinto permaneceu no sofá, um sexto foi encontrado pela garota, e um décimo recuperado pelo amante: seis pérolas permaneceram no colar". ${ }^{119}$

Seu próximo passo é baseado em uma sugestão de Joseph Conrad, para quem a biografia de uma pessoa poderia ser reduzida a três termos: "Ele nasceu, ele sofreu, ele morreu". Frampton descarta o primeiro e o terceiro como os limites da série; se foca no segundo como o desenvolvimento da narrativa biográfica, e o considera como a incógnita $x$. Diferentes narradores elaboram a equação em diferentes níveis de complexidade, construindo operações que envolvem a relação de $x$ com outros termos. Ele apresenta então a equação

$$
a x+b=c,
$$

\footnotetext{
118 Frampton, “A Pentagram for Conjuring the Narrative”, Op. cit., p. 144.

119 Ibid.
} 
que pode ser reescrita pelo "ponto de vista" de cada um de seus elementos. Por exemplo:

$$
a=\frac{c-b}{x}, b=c-a x, c=a x+b
$$

ou mesmo

$$
0=c-\frac{b}{a x}
$$

Os valores de cada termo são variáveis; a equação permanece a mesma para qualquer série de valores que mantenha essas relações. Nas palavras de Frampton, esta equação é "um padrão estável de energia pelo qual pode passar uma infinidade de tétrades numéricas". A partir desta terminologia ele descreve a narrativa como um "padrão estável de energia pelo qual pode passar uma infinidade de personagens". ${ }^{120}$ Vemos aqui uma espécie de redução e abstração da narrativa a seus elementos constituintes, como no formalismo de Vladimir Propp, ou como na descrição de Kenner para o método de James Joyce em Ulisses:

Todas as versões da mesma trama, independente do ponto de vista, possuem o mesmo sistema de interconexões. Podemos utilizar um termo da topologia e chamá-las de homeomórficas; Joyce viu que a trama da Odisséia e a de Hamlet eram homeomórficas, uma concentrada no pai, outra no filho, mas comparáveis na estrutura dos incidentes. ${ }^{121}$

Em uma entrevista, Frampton descreve mais diretamente sua posição sobre o papel da narrativa no cinema, e sua inevitabilidade como algo consideravelmente mais abstrato. Ele cita Brakhage mais uma vez, lembrando que este descreveu Arnulf Rainer (filme de 1960 de Peter Kubelka, constituído inteiramente por padrões alternados de fotogramas pretos e brancos, silêncios e ruídos) como a respiração de um homem que sobe e desce uma série de escadas. Esta descrição obviamente não diz respeito ao que é visto na tela - durante todo o filme, vê-se a tela completamente negra por alguns instantes, depois a tela completamente branca, às vezes em alternância extremamente rápida. A descrição de Brakhage seria uma maneira de capturar a forma geral da obra, o padrão formado pelas relações entre esses elementos. Frampton diferencia o padrão de

\footnotetext{
${ }^{120}$ Ibid., pp. 146-147.

121 Kenner, The Pound Era (Berkeley: University of California Press, 1973), p. 33.
} 
Arnulf Rainer daquele de The Flicker (filme de 1963 de Tony Conrad, também constituído por fotogramas pretos e brancos), ${ }^{122}$ ao qual ele atribui um aumento e diminuição de "densidade de evento",

muito como uma curva abstrata, como, digamos, um conto de Chekhov, em que, por exemplo, há uma crise em que duas pessoas ou uma família são separados.

[...] E então dez anos depois há um pico secundário de densidade de evento em que eles se reúnem, depois do qual a curva retorna a zero. ${ }^{123}$

É evidente que a noção de narrativa de Frampton não é a mesma de Bazin ao falar da narrativa, do "relato", como o ponto comum entre a literatura e o cinema. O relato de Bazin envolve, na totalidade dos casos descritos, uma psicologia comum, um ponto de vista sobre uma realidade possível - o que na maior parte dos casos envolve as noções de verossimilhança e plausibilidade citadas por Kenner. O mais próximo desse posicionamento que encontramos nos escritos de Frampton é sua descrição de Malone Morre, o romance de Beckett, visto como a jornada da consciência de um personagem, realizada pela divisão de sua unidade em duas partes: o orador e o leitor. Mas a proximidade não se mantém; Malone, como Frampton nos lembra, não é descrito com precisão, e nem o são suas ações ou o próprio espaço onde ele se encontra na ficção. A obra de Beckett é vista por ele como uma digressão consciente, um padrão organizado sobre as páginas e que realiza parte da imaginação daqueles que o encontram, enquanto o encontram. Ainda que Bazin dê importância ao estilo do autor do romance como um fato a ser considerado no processo de adaptação para o cinema, e do uso de um estilo propriamente cinematográfico para realizar a narrativa de acordo com o espírito da obra original, de maneira alguma podemos dizer que ele se refira a obras do cinema e da literatura como partilhando "uma curva abstrata".

Em um ensaio fundamental para a integração de seu pensamento - e citado por ele mesmo como uma espécie de manifesto - Frampton desenvolve o que chama de uma "metahistória" do cinema. O termo não é definido no texto, mas por sua ampla utilização em outros campos, podemos supor que o prefixo "meta" indique o direcionamento do estudo para os fundamentos de determinada disciplina, o que implica

\footnotetext{
${ }^{122}$ Para mais detalhes sobre as diferenças entre Arnulf Rainer e The Flicker, ver Malcolm LeGrice, "On The Flicker", in Peter Gidal (ed.), Structural Film Anthology (Londres: British Film Institute, 1978), pp. 135-136.

${ }^{123}$ Frampton, "Interview at the Video Data Bank", in Jenkins, Op. cit., p. 187.
} 
em uma abordagem que "dá um passo para trás", realizando uma observação mais distanciada daquele campo de conhecimento, posicionando-se em suas fronteiras. Encontramos, por exemplo, na proposta de Hayden White, em que a investigação metahistórica é feita a partir das bases do discurso histórico: se todos os historiadores, independente de suas ideologias, utilizam palavras, modos de conceptualização e figuras retóricas, estes são os objetos através dos quais o metahistoriador identifica padrões no campo de estudo da história. ${ }^{124}$ Em resumo, o metahistoriador não faz história "propriamente dita": ele estuda os modos pelos quais essa história pode ser feita.

Na busca pelos parâmetros através dos quais o metahistoriador do cinema conduziria sua pesquisa, Frampton parte da definição já citada do material fílmico, a própria superfície física da faixa de filme. Ele reforça que a ilusão espacial em profundidade e a representação do movimento contínuo são possibilidades, mas não condições inevitáveis. E acrescenta a estas a noção de que, pelo exame da lógica estrutural da faixa de filme, não encontramos evidência que permita diferenciar "material bruto" de "obra terminada" - essa diferenciação depende de uma condição social, externa ao material fílmico, portanto alheia aos seus objetivos.

Assim como o metahistoriador de White identifica os tropos literários que constituem o discurso histórico, Frampton apresenta sua metahistória como uma maneira de identificar os princípios envolvidos na composição do discurso fílmico. A descrição do campo histórico de White é análoga à descrição do campo do cinema para Frampton, e é essa a direção tomada por ele ao apresentar uma metáfora que ele chama de cinema infinito:

Uma câmera polimorfa sempre esteve ligada, e estará para sempre, com sua lente focada em todas as aparências do mundo. Antes da invenção da fotografia estática, os fotogramas do cinema infinito eram vazios, como pontas pretas; até que poucas imagens começaram a aparecer sobre a interminável faixa de filme. Desde o nascimento do cinema fotográfico, todos os fotogramas estão preenchidos por imagens. ${ }^{125}$

\footnotetext{
${ }^{124}$ Ver a introdução de White em Metahistória: A Imaginação Histórica do Século XIX (São Paulo: Edusp, 1992).

125 Frampton, "For a Metahistory of Film", Op. cit., p. 134.
} 
A metáfora de Frampton evidencia mais uma vez a afinidade de seu pensamento com as ficções de Jorge Luis Borges. Seu cinema infinito é como a "Biblioteca de Babel" do conto homônimo: a definição dos elementos e do conjunto de todas as possibilidades envolvidas em suas articulações. Um "campo puramente combinatório", para usar uma expressão de Paul Valéry. ${ }^{126}$

A relação do cinema infinito de Frampton com a realidade sensível é obviamente diferente daquela proposta pelo cinema total de Bazin. Enquanto Bazin busca os modos pelos quais o cinema poderia manter a integridade do real, e principalmente como as condições sociais e históricas do cinema propõem novos métodos e interpretações para a própria realidade, Frampton estipula o que parece ser uma transposição de sua definição da realidade como "a gramática e a sintaxe da fotografia". Se todos os fotogramas são determinados pela estrutura material da tecnologia cinematográfica, a composição fílmica se torna o ato de apreender os elementos e ordená-los de modo a criar o sentido desejado. Duas ordenações dos mesmos elementos configuram diferentes obras, como visto nos filmes de Kubelka e Conrad. Da mesma forma, uma obra não necessita gerar material próprio, original; pode-se reutilizar material alheio para que novas relações sejam estabelecidas, como em Tom, Tom, the Piper's Son (Ken Jacobs, 1969) ou Outer Space (Peter Tscherkassky, 2000).

\section{Os caminhos da metahistória}

Algumas obras de Frampton podem servir como exemplos de suas preocupações teóricas aplicadas e reconhecidas na composição fílmica. Seu interesse pela linguagem e pela fotografia sugeriu a ele um paradoxo após um encontro com Anémic Cinéma (1926), de Marcel Duchamp. ${ }^{127}$ No filme de Duchamp, discos com frases dispostas em espiral giram sobre um fundo negro; as palavras, pelo movimento e pela maneira como são dispostas, são confundidas em seu sentido, e as espirais, centrípetas, sugerem um espaço em profundidade que não existe de fato. O paradoxo que Frampton diz ter reconhecido envolve dois pontos: (1) depois que se aprende a ler, não se pode

\footnotetext{
${ }^{126}$ Cf. Paul Valéry in Brian Stimpson (ed.), Cahiers/Notebooks 2 (Frankfurt: Peter Lang, 2000), p. 79.

127 Ver a entrevista de Frampton em Scott MacDonald, A Critical Cinema (Berkeley: University of California Press, 1988), p. 48.
} 
desaprender; ao olhar para uma palavra, ela deve ser lida, a não ser que suas fontes sejam grotescamente deformadas; (2) ao olhar para uma imagem fotográfica, reconhecemos inevitavelmente um espaço ilusório, com certas características táteis, que podem inclusive sugerir alguma profundidade. Ele então planeja a criação de uma obra que se volte diretamente para essa relação.

Zorns Lemma (1970) possui três seções, cada uma com uma estratégia de composição particular. Na primeira, ouvimos uma voz feminina recitar um texto didático do início do século XIX, direcionado para o ensino do alfabeto através de lições morais e referências bíblicas. A voz é ouvida em volume, ritmo e entonação constantes, enquanto a tela permanece completamente escura. Ao final do texto, vemos imagens breves, cada uma durando um segundo: placas de metal com as 24 letras apresentadas em ordem alfabética. Ao final do alfabeto, tem início a segunda parte, a mais longa do filme.

Na segunda parte, completamente silenciosa, Frampton mantém a estrutura do alfabeto, mas em vez de placas de metal, ele nos apresenta uma série de planos de letreiros e palavras escritas em diversos contextos urbanos. Vemos uma imagem que contém uma palavra iniciada com a letra $A$, disposta sobre uma superfície concreta e cujos aspectos "ilusionistas" são reforçados pela maneira como é filmada, com todo o espaço focalizado e um movimento sutil revelando que não se trata de um plano fixo sobre um tripé, mas que a câmera é operada manualmente. Em seguida, o mesmo ocorre com uma palavra iniciada com a letra $B$; em seguida, com a letra $C$; e assim por diante. Ao final do alfabeto, retornamos ao início, e o ciclo se repete, com novas imagens. Todas as imagens possuem a mesma duração, o mesmo pulso de um segundo que apresentou as placas de metal no final da seção anterior.

Temos, então, uma espécie de catálogo pictórico de uma metrópole, composto sob a ordem do alfabeto. Uma expressão direta do paradoxo entre a palavra e a imagem: reconhecemos palavras, award, zenith, cinema, walk; reconhecemos paredes, galerias, lojas, jornais; mas em cada imagem, durante o mesmo período de tempo, reconhecemos uma unidade que contém de uma só vez o significado abstrato e a presença concreta dos elementos, tanto a estrutura da linguagem como a textura dos objetos.

Um desvio surge após algumas repetições do ciclo do alfabeto. Onde esperamos encontrar a imagem de uma palavra iniciada com determinada letra, somos surpreendidos por uma imagem desprovida de qualquer presença verbal. No momento 
em que veríamos uma imagem correspondente à letra $X$, vemos, em vez dela, e também por um segundo, um plano próximo e tremido de uma fogueira. No ponto onde encontraríamos a imagem correspondente à letra $S$, reconhecemos, pela mesma duração, o plano de um rinoceronte. Logo percebemos a alteração na estratégia de apresentação: cada imagem verbal será substituída por uma imagem não-verbal.

Enquanto as imagens verbais eram completamente renovadas a cada ciclo, o novo conjunto de imagens permanece o mesmo a cada apresentação, de modo que a imagem da fogueira sempre está no ponto correspondente à letra $X$. De acordo com Frampton, todas as imagens deste conjunto foram filmadas em sequência e em continuidade, e dispostas da mesma maneira sobre a estrutura da obra. ${ }^{128}$ Algumas constituem ações nas quais não podemos identificar qualquer progressão - por exemplo, uma árvore sobre um campo, sem qualquer movimento ou alteração aparente, ou uma criança brincando num balanço, em movimento incessante e repetitivo. Outras formam progressões claras, cujo objetivo ou conclusão podem ser previstos - por exemplo, um recipiente é preenchido, e a cada retomada o vemos mais cheio; uma parede é pintada, e a cada retomada a vemos mais próxima de estar completamente coberta de tinta; uma tangerina é descascada, e aos poucos percebemos que algo acontecerá quando ela for totalmente descascada.

Algo de fato acontece quando todas as progressões chegam ao fim: passamos à terceira seção do filme, que é composta por um único plano fixo que mostra um casal visto à distância, caminhando sobre um campo coberto de neve, acompanhado por um cachorro. Ouvimos sobre essa imagem um texto recitado por diferentes vozes femininas, cada uma falando uma única palavra, seguindo o mesmo padrão de uma palavra por segundo. ${ }^{129}$ Ao término do texto, o casal está prestes a desaparecer na imensidão da paisagem; a imagem é invadida algumas vezes por uma luz branca, até ser completamente tomada por ela, e o filme chega ao fim.

As preocupações de Frampton envolvem aqui, como em sua descrição do campo metahistórico, a articulação de diferentes combinações dos elementos fílmicos. Seu interesse no paradoxo entre o gráfico e o plástico, entre o verbal e o "natural" (as imagens verbais são necessariamente feitas pelo homem, enquanto as outras envolvem “documentos não-manipulados"), o leva a estabelecer o alfabeto como estrutura fixa

${ }^{128}$ Cf. Frampton, “Zorns Lemma: Script and Notations", in Jenkins, Op. cit., p. 199.

${ }^{129}$ O texto é "On Light, or the Ingressions of Forms", de Robert Grosseteste, bispo e filósofo britânico da Idade Média. Para uma transcrição, ver Frampton, Op. cit., pp. 194-195. 
sobre a qual dispõe conjuntos de elementos. Na primeira seção, temos acesso à articulação verbal através do som, desprovida de imagens. Na segunda seção é evidenciado o caráter pictórico e dinâmico das imagens; o paradoxo é, de certa forma, reforçado com a manutenção do alfabeto, até que as imagens naturais tomam conta e estabelecem um novo conjunto em que o movimento é a regra e as referências verbais parecem ser negadas. Na terceira parte, retorna a articulação verbal através do som, desta vez sobre uma imagem que sugere um único movimento contínuo.

Assim como na descrição dos filmes de Kubelka e Conrad como "curvas abstratas", Frampton interpreta Zorns Lemma como "uma longa transição". A passagem de uma seção à outra, com a mudança das estratégias de composição, representa para ele uma passagem entre diferentes modos de percepção. A esfera verbal e sonora da primeira parte, ele diz, "esvazia os olhos para receber o que virá depois". O segundo momento confronta o paradoxo entre a percepção verbal e a visual, entre os conteúdos concretos e abstratos das imagens. O filme então se afasta gradualmente da esfera verbal, substituindo as palavras por imagens desligadas do contexto linguístico, sugerindo todo um universo pela indicação de uma série de objetos. Finalmente, "tendo visto demais", a terceira parte nos dá uma única imagem, um único movimento, com os aspectos verbais retornando como uma construção cuja superfície sonora é evidenciada. ${ }^{130}$

A ordem do alfabeto funciona como uma garantia para que a disposição de palavras seja arbitrária, e que a sucessão de palavras não forme poemas ou combinações que possuam algum sentido - a tensão entre o significado e a imagem permanece, assim, no interior de cada plano, e não na estrutura geral. A montagem do filme permanece uma articulação não-linear, mais próxima da montagem vertical como definida por Eisenstein: menos como organização melódica, e mais como a indicação de pontos harmônicos, como numa série de acordes. A linearidade é identificada com a lógica linguística; a seção inicial é entendida pela sucessão de palavras, enquanto a segunda evoca uma hierarquia que só é esgotada com a inclusão de imagens não verbais. Dessa forma, o "universo" sugerido pelo conjunto final de imagens naturais, apesar de baseado na modulação do espaço e do tempo, tende a uma não-linearidade, à eliminação de qualquer centro comum que estabeleça relações causais entre uma

${ }^{130}$ As expressões são de Frampton, em sua descrição do filme contida no DVD A Hollis Frampton Odyssey (EUA: Criterion, 2012). 
imagem e outra. Este é um aspecto que sugere a busca de Frampton pela "contraparte da linguagem": a progressão do filme é a do afastamento do universo linguístico, em direção a uma espécie de articulação própria da relação entre a imagem e o som. $\mathrm{O}$ aspecto rítmico do texto final é ressaltado enquanto a continuidade e a luminosidade da imagem - seus aspectos constitutivos - são apresentadas de maneira mais direta.

Após Zorns Lemma, Frampton completa um conjunto de filmes chamado Hapax Legomena. Cada um dos filmes é tido como uma obra autônoma, mas todos são reunidos sob uma preocupação comum: a exploração das condições próprias do cinema através da aproximação deste com outras artes. Falaremos aqui apenas dos três primeiros filmes: Nostalgia (1971), Poetic Justice (1972) e Critical Mass (1971).

Nostalgia mostra uma série de doze fotografias sendo gradualmente queimadas sobre uma placa incandescente, enquanto ouvimos uma voz narrar histórias do período em que as fotos foram tiradas. Cada uma é vista em um plano separado, mas idêntico, que termina quando a fotografia se desfaz em cinzas, e então passamos à fotografia seguinte após o intervalo de alguns segundos em uma tela preta. A narração segue um princípio que é percebido na passagem de uma foto a outra: não ouvimos a descrição correspondente à imagem que vemos naquele momento, e sim a da imagem que veremos a seguir. Dessa forma, a primeira fotografia é acompanhada pela descrição da segunda, que é acompanhada pela descrição da terceira, e assim por diante; não ouvimos a descrição da primeira fotografia, e não vemos a última fotografia descrita.

Poetic Justice mostra uma série de folhas de papel dispostas sobre uma mesa, contendo textos que descrevem cenas de um roteiro. $\mathrm{O}$ enquadramento é fixo, como em Nostalgia, mas diferente deste, o filme é silencioso. Vemos a mesa com uma xícara de café e um cacto; entre os dois objetos, no centro do quadro, as folhas de papel. No início, vemos apenas uma folha em branco, até que um corte faz aparecer a primeira página do roteiro; todas as páginas seguintes são apresentadas da mesma maneira. $\mathrm{O}$ roteiro envolve três personagens, referidos no texto como "eu", "você", "seu/sua amante" (your lover).

Critical Mass começa com uma tela preta, e ruídos que aos poucos se tornam inteligíveis: trata-se de uma discussão entre duas pessoas, mas com o áudio sendo repetido a partir de um padrão que Frampton descreve como "dois passos para trás e um passo para frente" - it was a very / it was a very spon- / was a very spontaneous / a very spontaneous th- / -ery spontaneous thing. A imagem finalmente surge, e vemos o casal 
enquanto ouvimos suas vozes, dois jovens com roupas negras sobre um fundo branco. Por alguns minutos, vemos o casal discutindo, com os cortes no som sendo repetidos na imagem, mantendo a sincronia. Até que mais uma vez surge a tela preta, e quando a imagem retorna, já não está mais em sincronia com o som.

O termo que dá nome ao conjunto, Hapax Legomena, é descrito por Frampton como vindo do grego, significando "coisas ditas uma única vez", e sendo geralmente empregado para palavras que ocorrem apenas uma vez na obra de um autor ou em toda uma literatura. Uma consequência é que o significado da palavra depende inteiramente de seu contexto. O contexto de Hapax Legomena é o que ele diz ser uma mesma forma ou ação, que ocorre em cada um dos filmes, e também algumas vezes em um mesmo filme: uma curva descendente, "que esvazia o quadro", complementada por uma curva ascendente, "que preenche o quadro". 131

Em Nostalgia, por exemplo, "acreditamos" no que a imagem fotográfica representa, mas tão logo ela é consumida pelo fogo, percebemos que ainda permanece algo a ser visto: as cinzas que reforçam sua condição de objeto, de modo que há uma passagem de um nível visual para outro, da fotografia como nada para a fotografia como algo. O processo de incineração é o que realiza esta passagem, e também aquela entre a condição estática da imagem fotográfica e a condição dinâmica do objeto em chamas. Da mesma forma, ouvimos o desenrolar das histórias, antecipando a imagem seguinte, enquanto observamos a imagem presente na tela, recordando sua descrição prévia. Há um cruzamento complexo entre o processo narrativo e o processo físico, entre a formação de imagens mentais e a deformação de imagens físicas.

Esse cruzamento ocorre de maneira mais concentrada em Poetic Justice, em parte por ser um filme silencioso, mas principalmente pela neutralização de alguns elementos. Não só não há som como não há movimento propriamente dito; o espaço, tanto o quadro como a configuração geral no interior do quadro, sofre alterações mínimas. O ritmo dos cortes, que apresentam as páginas do roteiro, também não é evidenciado como em Zorns Lemma; cada página permanece tempo o bastante para que possamos apreender parte de sua "substância" temporal. Toda a atenção se volta para a construção de um universo imaginário a partir dos elementos concretos, o que Frampton chama de "a substituição de uma ressonância física por uma ressonância mental".

${ }^{131}$ A referência para as descrições e comentários de Frampton é o registro em áudio de um debate de 1972, "At Binghampton University". Disponível em: http://www.ubu.com/sound/frampton.html. Acesso em 22 de julho de 2014. 
Critical Mass é o único dos três filmes que possui alguma convergência entre o campo visual e a faixa sonora, além de ser o que mais se aproxima da composição de uma cena propriamente dita. Mas a montagem, incessantemente interrompendo, retornando e retomando o material, reprocessa essa cena de modo que a sincronia toma uma forma inteiramente diversa daquela de uma narrativa tradicional. A imagem sugere uma continuidade subjacente - os gestos dos atores, bem como suas falas, sugerem o registro de um período único -, mas o que é posto em primeiro plano são os diferentes contornos que a imagem e o som tomam conforme suas posições são restabelecidas. A repetição dá um caráter musical e coreográfico à obra, e os aspectos mais superficiais dos atores e do texto alcançam uma dimensão maior conforme os percebemos fora de sincronia.

Vimos que Zorns Lemma é separado em três partes, e que elas funcionam como etapas em um mesmo desenvolvimento. No início, o quadro tem suas funções neutralizadas ("esvaziadas", nas palavras de Frampton): seus limites materiais e sua disposição metafórica são diminuídos pela cobertura total da luz do projetor, enquanto toda a atenção é voltada para o texto sendo recitado. A segunda parte inverte essa relação, surgindo como um feixe de possibilidades pictóricas, organizadas em diferentes direções. O pulso de um segundo da montagem não permite a concentração na realidade concreta das imagens em sua extensão temporal, apenas sua percepção imediata, e seu componente linguístico mantém um grau de abstração constante. Por grande parte de sua duração, Zorns Lemma marca a passagem de uma palavra a outra, de uma configuração pictórica a outra, submetidas a uma ordem arbitrária. A alteração na segunda seção - a substituição das imagens verbais pelas imagens naturais - retira gradualmente o componente abstrato e dispersivo das imagens, incluindo diferentes categorias de movimento e progressão na mesma série, através do mesmo ritmo. Desprovida da dimensão verbal, a imagem parece não mais ser contradita ou abstraída, mas afirmada em sua presença; o retorno aos mesmos planos reforça esse ponto, construindo ações contínuas dentro do mesmo sistema. Na terceira parte, somos finalmente acolhidos pelo movimento contínuo, pela presença da imagem como unidade constituída pela luz, enquanto o texto (que trata justamente da luz como elemento formador do universo) é recomposto para que sua dimensão puramente sonora seja enfatizada, como um coral de palavras que apenas indiretamente sugere um significado abstrato. 
Os capítulos de Hapax Legomena realizam operações semelhantes. Em todos eles há um enquadramento fixo, e todos tomam como ponto de partida a plausibilidade da ilusão fotográfica. Mas não temos necessariamente a "máscara" espacial de Bazin, e sim uma circunscrição que reforça o caráter metafórico defendido por Frampton. Isso ocorre através das diferentes maneiras como o exterior do quadro, e as próprias relações entre os quadros são sugeridas, principalmente pelo uso da linguagem. Se em Nostalgia partimos literalmente das fotografias, e dos eventos por elas representados, logo nossa atenção é desviada para a posição dos objetos fotográficos dentro do sistema narrativo proposto pela montagem. Enquanto o paradoxo de Zorns Lemma era aquele entre a palavra lida e a imagem vista, Nostalgia parece transpor o mesmo problema para a imagem vista e a imagem construída mentalmente pela audição da linguagem (depois que aprendemos uma linguagem, não podemos "não entendê-la", a não ser que sua pronúncia seja grotescamente alterada). O quadro, nesse sentido, não sugere mais uma realidade exterior, visível e plausível pela ontologia fotográfica, mas tem sua função metafórica desenvolvida com a passagem de uma fotografia a outra. É fundamental que a fotografia inicial não seja descrita, e que a final não seja vista, pois é apenas com as duas "pontas" abertas que o filme mantém esse direcionamento: partimos da realidade representativa e imediata em direção às possibilidades abstratas que coexistem com a (ainda que se sobreponham à) presença concreta dos objetos.

Poetic Justice parte do quadro, o limite espacial reconhecido como registro de uma realidade, como o ponto de referência para toda a ficção construída pelo texto. A tensão entre palavra e imagem é vista por um ângulo diferente daquele de Zorns Lemma. O que interessa a Frampton aqui não é a tensão e a resolução das duas esferas, mas a manutenção de uma delas, tornada fixa (o enquadramento, assim como a disposição e iluminação dos objetos) enquanto toda a progressão se realiza na outra (a narrativa estabelecida a partir do roteiro). A imagem fotográfica se comporta como um elemento imóvel, impassível, afirmando nada que não seja sua própria presença; mas o texto, continuamente sendo desenvolvido e se referindo àquele espaço visualizado, cria camadas de significado e pontos de ligação com outros espaços, imaginados, acrescentando sentido ao que seria a pura experiência visual.

O espaço cênico em Critical Mass só é percebido indiretamente como unidade, pela continuidade sobre a qual somos carregados para trás e para frente, como numa linha imaginária. Esse espaço parece mais aberto que o dos filmes anteriores, pois o 
enquadramento não reforça os limites materiais da tela, e sim a incompletude dos corpos dos atores dentro dela. É a materialidade da própria película que é reforçada pela montagem, pela intervenção do corte na continuidade, e da própria desaparição e aparição da imagem, para/da tela preta. Essa textura, o reforço da superfície, é sempre presente; é sob ela que percebemos o que mais se aproxima de um movimento interno do drama, pelos gestos dos atores. Mas isso ocorre apenas enquanto há a sincronia entre a imagem e o som - quando os dois elementos saem de sincronia, a textura toma conta.

Uma característica presente tanto nos filmes aqui comentados como em outros filmes de Frampton é sua preferência por uma organização sistemática do material. No período em que Zorns Lemma foi terminado, Frampton foi incluído por P. Adams Sitney no conjunto de cineastas que ele chamou de estruturais, cujas obras privilegiariam os princípios gerais de organização como maneira de determinar toda a experiência, "em que a forma do filme como um todo é predeterminada e simplificada, e no qual esta forma é a primeira impressão da obra". ${ }^{132}$

O termo foi amplamente discutido, e inclusive renegado por alguns dos cineastas (entre os quais estão Michael Snow, Ken Jacobs e Paul Sharits). Frampton, apesar de renegar a nomenclatura como mais uma tentativa de definir e etiquetar artistas, em sua entrevista a Robert Gardner parece aceitar que sua obra enfatize as "estruturas". E em outra entrevista, ao comentar Magellan, o projeto do qual se ocupou durante seus últimos anos, parece especificar quais seriam para ele os pontos mais interessantes nessa tendência:

O que me interessa em todos esses sistemas racionais fechados e interativos é a maneira particular - o ponto particular em sua operação - em que eles mais começam a se parecer com o universo. E é neste ponto que, depois de estarem em operação por algum tempo, eles começam a gerar discrepâncias, valores irracionais, a acumular erros. Onde as operações começam a interferir umas com as outras de tal maneira que o que é gerado parece não ser permutado, mas ser absolutamente contínuo, se tornando - se acreditamos em causalidade causalmente lisos, mas em tal nível que parece falhar incessantemente em desentricar as linhas de auto-interferência do sistema. ${ }^{133}$

\footnotetext{
${ }^{132}$ Sitney, Visionary Film (Nova York: Oxford University Press, 2002), pp. 347-348.

${ }^{133}$ Deke Dusinberre e Ian Christie, "Episodes from a Lost History of Movie Serialism", in Film Studies, $n^{\circ} 4,2004$, p. 111.
} 
A busca de Frampton por sistemas que "comecem a se parecer com o universo", e cuja continuidade seria alcançada justamente pela descontinuidade, é um dos pontos de ligação com seu ideal de uma contraparte da linguagem que sirva de expressão para a consciência. A quebra da estrutura do alfabeto em Zorns Lemma - a expansão das possibilidades visuais com as imagens naturais - é um exemplo dessa operação, bem como a substituição da fragmentação pela única imagem em continuidade: o apontamento da imensa variedade de modos pelos quais a luz pode ser articulada, através do fogo, da água, incidindo sobre vegetais, minerais e animais, em padrões recorrentes ou em eventos naturais. Os processos que afetam a memória das imagens em Nostalgia passam necessariamente pela materialidade das fotografias, mas a sugestão de seus significados através da narração decorre de um conhecimento prévio, de um acúmulo de informações que utiliza a realidade externa para construir o movimento ambíguo entre texto e imagem - entre os dois suportes, como entre o passado e o futuro, há uma área em que parece existir apenas a constante transformação da matéria, na qual reconhecemos a transformação da própria consciência. ${ }^{134}$ A ambiguidade em Poetic Justice não se encontra na totalidade da imagem, que é mantida com o máximo de regularidade possível, mas no simples reconhecimento de traços dentro dela que, associados a conteúdos linguísticos, realizam gradualmente a triangulação entre três pontos imaginários, entidades completamente indefinidas, dos quais um é o reforço da presença de um olhar sobre aquele espaço, pela simples referência de um tempo verbal. Em Critical Mass, reconhecemos os personagens do drama, e sua disposição no espaço visual é a garantia de que se referem a um jogo do qual somos espectadores; mas a insistente reestruturação do material, de uma continuidade que sabemos "real" pelo contexto, nos torna, mais do que cúmplices, agentes ativos de outra encenação, que inclui os gestos e palavras em uma coreografia mais sutil, sobre o espaço da película, especialmente quando ocorre a separação entre som e imagem.

A aspiração de Vertov, a articulação dos próprios pensamentos, parece aqui tomar corpo em algum nível, em uma linguagem que utiliza palavras, mas não se limita a elas; que não segue a linearidade do discurso verbal, mas que parece processar

\footnotetext{
${ }^{134}$ No texto da narração do filme, ao referir-se a um autorretrato, Frampton (através da voz de Michael Snow) lembra que, desde que a foto foi tirada, todas as células do seu corpo foram substituídas, com exceção de seu sistema nervoso. Nesse sentido, a transformação é, além de tudo, orgânica. Estendendo esse princípio para a materialidade do filme, podemos concluir que todos os fotogramas registrados por Frampton já foram substituídos em suas diversas cópias, e a própria configuração que nos permite um contato com a obra atravessou um processo semelhante.
} 
operações análogas; que constrói uma estrutura mental, ou serve de base para sensações e idéias que surgem na consciência, e que apenas ganham vida através dessa articulação. Algo próximo da declaração de Duchamp ao largar a pintura pelo xadrez, de que as peças seriam “as letras do alfabeto que dá forma aos pensamentos", e que esses pensamentos podem traçar um desenho no tabuleiro, mas que a beleza do jogo, sua realização dinâmica, se daria de maneira puramente abstrata, na mente dos jogadores. ${ }^{135}$

\footnotetext{
135 Hubert Damisch, "The Duchamp Defense", in October, no 10, outono de 1979, p. 10.
} 


\section{Entre a matéria e a forma}

Começamos com narrativas que estabeleciam projetos de cinema a partir de referências ideais. Essas narrativas, o mito do cinema total de Bazin e o sonho de uma contraparte da linguagem por Frampton, foram descritas como pontas opostas de um mesmo espectro. À representação do mundo em sua própria imagem se opunha a expressão dos conteúdos da consciência, ambas compartilhando uma mesma tecnologia, a ser tornada invisível no caso do cinema total, e a ser passível de articulação no caso da contraparte da linguagem. Vimos que esses projetos serviram como pontos de partida para investigações mais voltadas ao terreno histórico em que encontramos os filmes. As interpretações de Bazin e Frampton para o que seriam uma ontologia e genealogia do cinema foram apresentadas, reforçando em alguns momentos a oposição iniciada por seus ideais, mas em outros apontando para questões comuns, às quais deveríamos considerar para entender as relações de proximidade, distanciamento ou complementaridade de suas teorias. Ambos pareciam efetuar uma aproximação crítica da história, mas esta ainda se dava tendo por referência de seus ideais. Foi necessário, portanto, um passo adiante, em direção às defesas de cada um para o que seriam os elementos básicos do cinema, e suas manifestações em obras específicas.

Se a oposição entre os respectivos "mitos" parecia ser absoluta, mutuamente excludente, aquela entre as ontologias/genealogias se situava num nível menos extremo. Bazin e Frampton concordam sobre os procedimentos envolvidos, mesmo sobre alguns dos processos pelos quais a fotografia passa até influenciar o surgimento do cinema (suas diferenças em relação à pintura, por exemplo). A discordância recai principalmente na ênfase de certos fatores, o que os leva a determinar diferentes funções ou possibilidades para o cinema como arte. É essa ênfase que vemos ser desenvolvida quando os dois se questionam sobre os fundamentos do cinema, e onde a complementaridade de suas ideias parece mais evidente, pois ambos concordam na divisão tripartida do que o cineasta encontra como ferramenta de trabalho - o quadro e seus desdobramentos, tanto em seu espaço interno como em sua integração numa série temporal -, mas o que definem como válido, ou como mais importante, são aspectos diferentes desses mesmos elementos. 
Em primeiro lugar, tanto Bazin como Frampton incluem o quadro como um dos elementos: Frampton enuncia isso diretamente; Bazin o faz indiretamente, por uma comparação com a pintura, o que condiz com sua preferência pela "definição do cinematográfico pelo não-cinematográfico". Em segundo lugar, descrevem o que podemos chamar de uma potencialidade, ou diferentes dimensões, deste quadro: Bazin compara o espaço do cinema com o do teatro, relacionando-o com a presença do ator e da cena; Frampton elabora sua definição da imagem fotográfica como passível de articulação como elemento isolado, e a estende para o próprio espaço físico da película. Em terceiro lugar, colocam a narrativa como decorrência da articulação temporal dos elementos anteriores. Vejamos as relações entre as diferentes interpretações, analisando um elemento de cada vez.

\section{O quadro centrífugo ou metafórico}

A tela, ou o quadro do cinema, para Bazin, difere daquele da pintura pelo que ele chama de seu aspecto "centrífugo". A pintura, uma das belas-artes, trabalha sua representação através da semelhança, enquanto o cinema, ontologicamente ligado a este real pela fotografia, o representa diretamente. Disso decorre que o espaço pictórico não sugere um espaço externo às suas fronteiras, à moldura da obra, mas se volta para seu interior. O cinema, por outro lado, sugere precisamente o espaço além de suas bordas: a câmera, ao limitar o espaço da realidade, sobrepõe a ela uma espécie de máscara, pois sua natureza ontológica garante que a realidade continua no espaço não visualizado. A borda limita a imagem, contendo-a, mas o fato de a imagem transbordá-la deve-se justamente à atividade em suas bordas. Nas palavras de Jacques Aumont, "as bordas são operadores ativos de uma transformação progressiva". ${ }^{136}$

Para Frampton, o papel do quadro não é o de mascarar a realidade, de realizar um recorte em sua unidade bruta, mas o de constituir "um ícone da fronteira entre o conhecido e o desconhecido". Frampton enfatiza o que considera o potencial metafórico do quadro. Dessa forma, seu interior é determinado primeiramente pelo que é visível, mas seu exterior (e depois, também o interior) não é sugerido apenas pela ligação

\footnotetext{
${ }^{136}$ Aumont, O Olho Interminável (São Paulo: Cosac Naify, 2004), p. 39.
} 
ontológica entre a fotografia e a realidade sensível, mas por níveis de abstração acrescentados à presença concreta. Em outras palavras, as bordas do quadro não são apenas materiais, mas também conceituais. Isso pode ser melhor entendido se considerarmos que Frampton não defende a representação de eventos de maneira realista como uma prioridade. Um fotograma para ele é, acima de tudo, o registro de uma configuração luminosa, que pode ser virtualmente irreconhecível como um objeto correlato do mundo sensível. Um plano é apenas uma série estável que direciona uma mesma configuração luminosa, não uma necessidade lógica do material. Para que o quadro, na forma do fotograma, seja o elemento básico de uma linguagem universal, Frampton parece exigir que ele seja tomado como um átomo, um ponto indivisível que marca a representação consciente em sua menor medida - "uma fotografia é apenas um fotograma isolado, retirado do cinema infinito".

Podemos realizar o cruzamento dessas concepções de quadro através de dois exemplos. Tomemos primeiramente o registro, pelos irmãos Lumière, da chegada de um trem à estação de La Ciotat (L'arrivée d'un train en gare de La Ciotat, 1895). A descrição da primeira projeção pública do filme já constitui uma espécie de lenda cinematográfica, mas sua veracidade histórica nos interessa aqui menos que os detalhes que evidenciam aspectos da composição da obra. A reação do público, segundo relatos, teria sido de completo pânico: surpreendidos pela reprodução do movimento, pela integridade e complexidade dos fatores envolvidos num mesmo evento, os espectadores teriam fugido da sala com a visão do trem, por medo de serem atingidos pelo próprio objeto representado. A história guarda alguma semelhança com a anedota sobre Zêuxis, de que este teria pintado uvas tão verossímeis que os pássaros tentaram bicá-las. $\mathrm{O}$ arrebatamento causado pela integridade da cena sugere também, é claro, alguma proximidade com o cinema total de Bazin, e são as características que apontam para essa integridade que parecem representar mais diretamente o que Bazin defende no uso do quadro cinematográfico.

O quadro do cinema, em sua potência centrífuga, é o que encontramos no filme dos Lumière. Não há qualquer elemento que reforce os limites materiais da tela, que busque enfatizar a autonomia interior da imagem como algo independente da realidade externa. Não há simetria ou moldura artificial, ou mesmo sugestão de equilíbrio entre as linhas de força, nada que traga um potencial estático ao enquadramento. Os trilhos cortam a tela em diagonal, e parte dela permanece imóvel enquanto o outro lado segue 
em movimento constante - mas não exatamente agitado - com a presença das pessoas. A progressão do filme, como o movimento do trem, é linear, estabelecendo a mudança nas proporções do quadro e tornando esse movimento um fator tanto espacial como temporal: o trem surge no horizonte e literalmente atravessa a tela. Esse movimento é reforçado pelas pessoas que partem em direção às portas, algumas deixando também o campo visível da ação.

O que temos, então, é um recorte contínuo de um evento imediatamente reconhecível, cujos elementos são integrados pela atração efetiva de seus movimentos, direcionados ou modulados pela própria moldura da composição. Não há controle sobre cada elemento no interior do quadro, apenas sobre as coordenadas gerais. A vivacidade do filme, a naturalidade de cada movimento microscópico, é diretamente proporcional à organicidade de suas relações internas, em sua aparência de infinita complexidade convergente. Retomando o termo de Aumont, a borda da tela é o agente transformador de uma ação progressiva, o fator que permite o mínimo de articulação dentro do registro, fazendo com que a "vista" dos Lumière seja, mais do que a criação, uma espécie de dinamização de um evento.

Comparando o filme dos Lumière com Critical Mass, temos distinções claras no uso dos espaços e na relação das pessoas neles envolvidas. No primeiro, a naturalidade reveladora dos movimentos (o que Bazin elogiava em Renoir) é apreendida e dissolvida no movimento geral, como se tudo o que é visto seguisse as mesmas leis gerais, naturais e independentes da criação humana. No segundo, essa naturalidade parece existir, mas é apenas entrevista através da montagem, que não cessa de dispersar e unir o que antes seria um único movimento, ou seja, que interage com essa dimensão, mas cria uma camada subjetiva sobre ela. A composição dos Lumière é baseada numa apreensão geral do evento; se há um centro gravitacional que coordena os elementos em seu interior, ele não é visível, não é colocado em foco, apenas intuído pelas várias interações e a sugestão de um universo externo. É disso que resulta sua qualidade de registro "objetivo" na concepção baziniana, que pressupõe um universo infinitamente complexo e integrado. O cinema, nesse sentido, mostra mais do que conseguimos imaginar. A composição de Frampton, por outro lado, é baseada justamente no foco de um princípio coordenador, da neutralização das referências espaciais. O fundo é uma superfície branca qualquer, da qual temos apenas uma noção da distância para os atores pelas sombras projetadas, e o que devemos intuir é aquilo que nos Lumière era um dado, a 
presença contínua e natural das pessoas - devemos necessariamente acrescentar essa intuição à obra, pois na concepção de Frampton sua lógica não corresponde à prioridade do espaço realista, mas à estrutura pontuada pelos cortes, em sua unidade abstrata, formada tanto pelo discurso e pelos gestos como pelo padrão rítmico que retoma a materialidade da película.

O segundo exemplo é Rhytmus 21 (1921), de Hans Richter. Segue uma descrição do filme por P. Adams Sitney:

Uma tela escura se divide no meio e se espalha até uma tela branca; uma série de permutações, de transições e mudanças em que preto e branco se alternam, dá lugar a formas geométricas, e dessa dialética de preto e branco, quadrados e linhas começam a surgir. $\mathrm{O}$ filme termina se transformando numa construção em preto e branco que lembra uma pintura de Mondrian. É uma construção no tempo, baseada em ritmos musicais, evocando o estilo pictórico de Mondrian, mas expandida a partir dos elementos absolutos das telas preta e branca. ${ }^{137}$

Richter é um dos principais nomes da tendência que, como vimos, era renegada por Bazin, de artistas que buscavam desenvolver uma espécie de linguagem do "cinema puro", a partir de seus elementos plásticos e rítmicos. A composição de Rhytmus 21 é em essência uma espécie de animação, uma série de imagens registradas em sucessão a partir de uma organização prévia; imagens temporalmente dispersas, em vez de imagens em tempo real que reforçariam seu vínculo com a realidade sensível. Esse é obviamente um primeiro ponto de afastamento em relação a Bazin, mas Frampton considera que o vínculo entre a imagem "registrada" e a imagem projetada passa necessariamente pela fisicalidade da faixa de filme: ele nos lembra que tecnologias como o zootrópio não se iniciaram com fotografias, mas com desenhos, e que a função do cineasta é, no fim das contas, a modulação da luz do projetor através dos fotogramas dispostos sobre a película. Dessa forma, os cartões fotografados por Richter, que são apresentados como formas abstratas, não parecem reforçar sua ligação com o referencial "real", mas com a própria imagem da película. ${ }^{138}$

\footnotetext{
${ }_{137}$ Sitney, "The Idea of Abstraction", in Film Culture, no 63-64, 1976, pp. 11-12.

${ }^{138}$ Para uma descrição e apresentação histórica de Richter e de outros cineastas com posturas semelhantes, ver o segundo capítulo de Malcolm Le Grice, Abstract Film and Beyond (Cambridge: The MIT Press, 1978).
} 
O caráter metafórico do quadro defendido por Frampton depende da suposição de que o limite da tela não é exatamente a máscara baziniana, mas uma área autônoma, cuja abstração é um fator crucial para realizar a sugerida ligação com os conteúdos da consciência. Os limites do quadro de Richter são postos em xeque desde o início: o espaço da tela - ou seja, o espaço compartilhado por todos os fotogramas - é dividido em partes que sugerem movimentos, que revelam sua escala e suas orientações. Vemos figuras de diversos tamanhos, crescendo, diminuindo, invertendo suas posições, surgindo e desaparecendo. O quadro como um todo é um espaço neutro, às vezes negro, às vezes branco, em cujo perímetro ocorrem as transformações. Essa neutralidade decorre da separação entre a imagem visualizada e a realidade sensível. A continuidade dos movimentos não diz respeito a de ações "reais", mas à composição conscientemente realizada por Richter, referente ao mesmo tempo a um espaço mental criado no espectador e à materialidade da película.

A abstração das formas de Richter, assim como sua concentração na autonomia do quadro fílmico, coincide então com o próprio material utilizado. Este é um ponto importante, pois é assim revelada uma qualidade inevitável do cinema. Uma aproximação com a visão de Bazin pode ser feita através da colocação de Jean Mitry de que a representação possui tanto o referencial espacial (em profundidade, ou seja, determinado ontologicamente pela realidade física) como o referencial absoluto do quadro, o eixo quadrilátero formado pelas linhas horizontais e verticais. O efeito do quadro é o de criar uma unidade formal entre os elementos que contém: ele é o denominador comum, com os quais aqueles objetos, na realidade sensível, não possuem originalmente uma relação. ${ }^{139} \mathrm{O}$ espaço "fora de quadro" existe no filme de Richter, mas ele é puramente imaginário, a representação de um espaço idealizado, na consciência. Quando as linhas brancas atravessam a tela, elas não operam como o trem dos Lumière, que sabemos ter um destino específico. As formas de Richter desaparecem materialmente, tanto da imagem projetada como da imagem na superfície da película; é apenas na unidade imaginada criada por suas relações que elas permanecem ligadas às referências do quadro, e pelas quais podemos imaginar seus movimentos como tendo um sentido. Por isso "entendemos" esses movimentos, reconhecemos as relações propostas; há uma unidade visível no filme, um conjunto de "melodias", ou padrões recorrentes.

${ }^{139}$ Cf. Mitry, Op. cit., pp. 75-79. 


\section{O espaço em profundidade e a materialidade da película}

A concepção espacial de Bazin é um acréscimo de dimensão à sua definição do quadro, uma extensão temporal do que para ele é a continuidade unificada da imagem fílmica. A comparação com o teatro, como ele nos diz, é inevitável: se o quadro é o limite bidimensional da imagem, a cena teatral é a circunscrição da área em cujas dependências flui a energia dramática. A manutenção da unidade do espaço é essencial para o aproveitamento dessa energia. Lembremos do comentário sobre o filme de Welles, em que a "voltagem da cena" permanece ligada à presença dos atores no cenário. Soma-se a isso a noção de que o cinema para ele é uma arte com uma vocação anti-antropocêntrica, ou seja, que, em sua objetividade fotográfica, registra aspectos da realidade independente destes estarem conscientemente dispostos como partes do drama. A fascinação de Méliès com as folhas das árvores se movendo no fundo de um filme dos Lumière é um exemplo dessa vocação. A unidade do espaço, sua complexidade orgânica, que sugere o movimento da natureza, que torna o drama um evento que integra e concentra as ações sob um mesmo princípio, é um efeito dependente da ontologia fotográfica tal como defendida por Bazin. É o que garante que o abandono e a imensidão em torno das ruínas de Nápoles tenham um peso efetivamente dramático no filme do Rossellini, e que a simples observação de um caminho longo a ser percorrido pelo casal tenha um caráter tão imediato que quaisquer conotações metafóricas parecem submetidas à realidade concreta da cena. Ou ainda que Welles possa atravessar com a câmera o espaço das mansões em Cidadão Kane e Soberba e, no decorrer desses movimentos, realizar a apreensão puramente sensível de suas dimensões de modo que elas constituam referências que permanecem estáveis em cenas seguintes, executadas com planos mais restritos e com mais cortes. O caráter metafórico de Frampton não parece exatamente ausente dos filmes elogiados por Bazin; ele parece, antes, submetido a um princípio de realidade baseado no espaço, e que regula seus aspectos conotativos.

Para Frampton, este espaço é um dado, mas em seus filmes o espaço é constantemente bombardeado por informações que problematizam sua unidade. Através da quebra de seu valor concreto pela interferência rítmica e verbal (Zorns Lemma) ou pela reiteração dos gestos e um atraso na continuidade (Critical Mass), o que é enfatizado é a própria textura e superfície do espaço fílmico. É como se houvesse 
diferentes espaços viáveis, coabitando em conflito um mesmo período. As referências externas, minimizadas pelos enquadramentos e pela concentração de seus pretextos, preparam ainda sua articulação do som e da narração como novas interferências nesse espaço. A unidade espacial não é mais concreta, ou pelo menos não é apenas concreta: ela depende (em Poetic Justice, por exemplo) e é ao mesmo tempo definida por uma camada que descreve seu entorno, expande sua influência, mas nunca determina claramente, e nunca revela diretamente aos sentidos sua presença.

A importância da materialidade da película na constituição da organização espaço-temporal das obras é um fator central em outro filme de Frampton, Palindrome (1969), inteiramente composto por pontas de negativo descartadas por laboratórios. Frampton selecionou as imagens que considerou mais interessantes, que tendem a certo "biomorfismo", e aplicou sobre elas uma estrutura métrica que repete um mesmo padrão com variações de posição e cor. O título se refere ao fato de que os padrões são apresentados de maneira simétrica: caso o filme seja visto de trás pra frente, ou mesmo invertido lateralmente, ele mantém sua característica de palíndromo. Mas o importante a ser citado é que, ao compor um filme unicamente com imagens que remetem à superfície da película, e cuja lógica é absolutamente externa, mecanicamente imposta sobre o material (ou seja, não há "melodias visuais" como em Richter), Frampton sobrepõe uma medida arbitrária sobre o próprio processo de projeção. Este filme (como todos os filmes) foi originalmente uma faixa contínua, e é apenas através do padrão criado por Frampton que podemos perceber as dimensões e proporções do quadro, bem como as dimensões e proporções do tempo da projeção.

As formas representadas por Welles em Cidadão Kane - a arquitetura dos lugares, as curvas e espirais dos ornamentos, o traçado feito pelas luzes nas diferentes superfícies - formam um todo, um volume espacial que é a própria câmara onde ocorre o drama dos personagens. O filme de Welles conta a história de um homem esmagado pelo acúmulo desmedido de matéria, encarcerado em suas dependências, acreditando dominá-las enquanto se deixa lentamente definir por elas. A célebre imagem final, o trenó com a inscrição nostálgica, é reveladora no sentido de que a própria lógica de sua trajetória é representada por um objeto, que finalmente é destruído. Este é o sentido, o espírito das formas do filme, moldado pela psicologia da narrativa. Essas formas diferem daquelas de Richter em Rhytmus 21 (ou das de Frampton em Palindrome) por terem uma conotação específica e nos remeterem à sua própria presença num espaço 
tridimensional análogo ao que experimentamos "fora do filme". Ao ver uma porta sendo aberta, ela nos revela um espaço específico, um salão, um quarto onde um drama determinado ocorre, e no qual somos inevitavelmente levados a considerar a psicologia envolvida. Mas ao ver a tela ser partida por linhas geométricas - em blocos de cores puras, o completo branco sobre o completo negro - elas não nos remetem a nada que não seja sua própria determinação material na superfície fílmica, e suas relações parecem existir apenas em nossa própria consciência. O que vemos é a demonstração de uma característica fundamental do quadro do cinema como um todo: a dimensão metafórica apontada por Frampton. Lembremos da descrição de Mitry para o referencial absoluto do quadro, de que é apenas através de suas proporções que apreendemos os objetos; seu sentido é contingente de operações absolutamente superficiais. As operações de Richter são abstrações de processos que podem ser realizados de diferentes maneiras; nos termos de Frampton, são padrões estáveis em que podemos imaginar uma infinidade de objetos. A abertura de uma porta de Welles seria uma das encarnações possíveis do movimento abstrato de Richter.

\section{Concretização e abstração da narrativa}

O terceiro elemento comentado por Bazin e Frampton, a narrativa, é certamente o mais complexo, em parte por incluir de certa forma os dois elementos anteriores. A narrativa para Bazin representa um olhar sobre o mundo; a unidade do mundo é pressuposta, e a perspectiva da câmera deve seguir a lógica interna dos eventos em vez de acrescentar articulações à realidade sensível. O alcance dessa perspectiva deve coincidir com as escolhas que determinam o "estilo" da obra, seus contornos propriamente estéticos e mesmo subjetivos. Nada que venha simplesmente "de fora" deve ser admitido, seja um corte ou um movimento, pois a verdade da cena depende da verdade do próprio espaço contínuo. A ambiguidade e o mistério essenciais do real não devem ser eliminados, mas revelados dentro da própria estrutura coordenada pela obra, de modo que o filme faça para esse processo temporal o mesmo que o âmbar faz com o corpo dos insetos - a fixação material que permite sua percepção através de uma delimitação. 
A narrativa para Frampton é acima de tudo um processo que decanta formas da consciência, que, se tentamos aproximar com o termo de Bazin, só "revela" algo na medida em que recria no espectador o processo que determinou a composição da obra em primeiro lugar. Ele reconhece em gravuras japonesas, por exemplo, o encontro entre processos semelhantes:

\begin{abstract}
Um padrão estável de energia uma vez trancou granito e gelo numa forma imutável além da compreensão humana; este mesmo padrão formou, no decorrer de eras, as próprias mentes de seus observadores, como forças magnéticas traçam em poeira metálica o contorno de uma rosa. ${ }^{140}$
\end{abstract}

Esse processo é material, como ele nos lembra ao falar sobre a superfície da película. A composição deve, portanto, realizar através da estrutura fílmica esse processo, transpor a consciência para imagens e sons, numa busca que retoma o ideal da linguagem universal.

Um cineasta que podemos tomar como exemplo para os dois pontos de vista é Robert Bresson. Bazin escreve textos sobre alguns de seus filmes, e P. Adams Sitney, numa interpretação que se aproxima em tom e terminologia de Frampton, dedica um ensaio à unidade de sua obra; podemos então cruzar as duas abordagens, para que um retrato dessa complementaridade possa ser mais claramente observado.

Bazin elogia dois filmes de Bresson, As Damas do Bois de Boulogne (Les Dames du bois de Boulogne, 1945) e Diário de um Pároco de Aldeia (Journal d'un curé de campagne, 1951). Seu elogio se estende à metodologia geral de Bresson, desenvolvida principalmente a partir do filme de 1951. Ele reconhece pontos positivos, ainda que pareçam ir de encontro a algumas de suas preferências, como que tentando incluir em seu pensamento uma aproximação com o "outro lado". Isso passa, naturalmente, por sua defesa da adaptação, e o respeito exigido ao texto: "Tanto quanto com os personagens e com o desequilíbrio que a evidência física deles introduz na ordenação dos acontecimentos, o adaptador deve ainda se preocupar com o texto". ${ }^{141} \mathrm{O}$ elogio se direciona para o "empobrecimento" das imagens que Bresson desenvolve, em vez de repetir a riqueza descritiva do livro de Bernanos, o que é reforçado tanto pela

\footnotetext{
${ }^{140}$ Frampton, "A Pentagram for Conjuring the Narrative", Op. cit., p. 142.

${ }^{141}$ Bazin, "Diário de um pároco de aldeia e a estilística de Robert Bresson", in Op. cit., p. 139. Originalmente em Cahiers du Cinéma, no 3, junho de 1951.
} 
interpretação dos atores ("modelos", para Bresson) como pela insistência no caráter elíptico das cenas. O olhar de Bresson é seco, sem grandes arroubos expressivos de luz ou forma, e a progressão dos eventos é pontuada pela voz do protagonista.

Há alguma estilização em Bresson, em sua decupagem marcante baseada na fragmentação dos objetos e na disjunção momentânea entre som e imagem. Este é um dos pontos que inicialmente seriam problemáticos para Bazin, mas no qual ele reconhece a elevação da unidade da narrativa:

sua estilização não é a abstração a priori do símbolo, ela se constrói numa dialética do concreto e do abstrato pela ação recíproca de elementos contraditórios da imagem. A realidade da chuva, o ruído de uma cascata, o da terra que se derrama de um vaso quebrado, o trote de um cavalo sobre o calçamento, não se opõem apenas às simplificações do cenário, à convenção dos costumes e, mais ainda, ao tom literário e anacrônico dos diálogos; a necessidade da intromissão deles não é a da antítese dramática ou do contraste decorativo: eles estão ali por sua indiferença e sua perfeita situação de "estranhos", como o grão de areia na máquina para prender o mecanismo. Se o arbitrário da escolha deles parece uma abstração, é a da abstração do concreto integral; ela arranha a imagem para denunciar a transparência, como uma poeira de diamante. É a impureza em estado puro. ${ }^{142}$

Essa unidade, para Bazin, não surge da ordem das imagens e suas ligações com as imagens anteriores e posteriores, mas pelo acúmulo do que ele chama de uma "energia estática”. Tanto a imagem como o som, em relativa distância e independência um do outro, organizam suas diferenças em uma mesma progressão. O som não é apenas um complemento, "ele reforça e multiplica [o acontecimento] como a caixa de ressonância do violino o faz com as vibrações das cordas". A estilização é alcançada não à maneira expressionista, ou através de uma sintaxe de montagem, mas pela condução dos elementos visuais e sonoros sob uma mesma lógica que se refere constantemente ao que não se encontra em quadro, que determina e dialoga com esse fora-de-quadro, e que no decorrer desse diálogo estabelece a unidade do real. ${ }^{143}$ A primazia que Bazin elogia em

\footnotetext{
142 Ibid., p. 142.

143 Os escritos do próprio Bresson expressam uma busca por essa postura. Ver Bresson, Notas sobre o cinematógrafo (São Paulo: Iluminuras, 2005), p. 47: “As trocas que se produzem entre imagens e imagens, sons e sons, imagens e sons dão vida cinematográfica às pessoas e aos objetos do seu filme,
} 
Bresson é a do objeto sobre a imagem, exemplificada pela conclusão de Diário de um Pároco, com a simplicidade "neutra" da cruz negra sobre o pano branco - não um signo abstrato, mas um traço visível da realidade. ${ }^{144}$

A interpretação de Sitney começa apontando que "narrativa" é um termo melhor do que "trama" para se referir aos filmes de Bresson, pelo fato de que a simples série de eventos a ser descrita tem menos importância do que a maneira como tais situações são apresentadas e percebidas. A narrativa é vista por ele como uma ordenação formal. Nesse ponto, não há uma distância marcante de Bazin, mas veremos que a ênfase não se dá na unidade concreta revelada através e em torno das formas, e sim da própria conjugação dessas formas.

Sitney argumenta que é necessário diferenciar duas estratégias de montagem que podem vir a conduzir a narrativa, que ele chama de linear e geométrica. A montagem linear estaria presente em cineastas menos preocupados com uma articulação formal evidente - o que sugere alguém como Rossellini, por exemplo. O estilo geométrico, por outro lado, seria exemplificado por aqueles que buscam evidenciar a construção formal, nomes como Eisenstein, Vertov e Kubelka, que fariam uso de

posições variadas de câmera, uma depois da outra, para articular uma geometria sólida do espaço em que os vários ângulos a partir dos quais uma ação é filmada, e a interação de planos próximos e distantes, se combinam para dar a ilusão de um espaço cúbico do qual a câmera é capaz de extrair uma série infinita de perspectivas. ${ }^{145}$

O emprego mais sistemático da geometria fílmica para Sitney é a metonímia. Identificada com os vanguardistas $\operatorname{citados}^{146}$, a multiplicação dos pontos de vista e a criação de contrastes entre as imagens seria a maneira de indicar uma unidade abstrata a partir de elementos dispersos. Bresson desenvolveria um método fundamentalmente antigeométrico, mas pela mesma figura, numa linearização da metonímia. A passagem cuidadosa de planos abertos para planos próximos, e os movimentos discretos da

e, por um fenômeno sutil, unificam sua composição"; ou p. 52: "Imagem e som não devem se ajudar mutuamente, mas que eles trabalhem cada um à sua vez numa espécie de revezamento."

144 Ibid., pp. 151-152.

145 Sitney, "The Rhetoric of Robert Bresson", in The Avant Garde Film, p. 185.

146 Mitry reconhece esse como um dos traços mais evidentes da montagem de Eisenstein em Encouraçado Potemkin (Bronenosets Potyomkin, 1925). Cf. Mitry, Op. cit., p. 39. 
câmera, enfatizariam as configurações isoladas de cada plano como moléculas narrativas independentes, em vez de faces ou ângulos de um cristal ilusório. ${ }^{147}$

Um Condenado à Morte Escapou (Une condamné à mort s'est échappé, 1956) é citado por Sitney como um exemplo da transferência realizada por Bresson, a passagem do suspense da narrativa para a fascinação com os meios pelos quais o suspense é construído. Os detalhes dessa construção - vistos pontualmente, em planos próximos, na estratégia de linearização da metonímia - recebem mais atenção que a situação geral, que não é apreendida de maneira clara, pois temos um conhecimento tão restrito quanto o do protagonista trancado em sua cela. O suspense nesse caso é o suspense da própria construção. Sobre o ritmo envolvido nessa construção, Sitney comenta:

\begin{abstract}
Apesar de Bresson deliberadamente distanciar o espectador ao enfatizar a estrutura dos eventos em vez de seus vetores emocionais, ele integra os filmes com ritmos ritualizados que guiam a consciência do espectador da textura de seus mecanismos formais para as ambiguidades da narrativa e o sentido de destino comum a todos os seus filmes. Os mecanismos formais empregados por Bresson não são espetaculares; ele evita metáforas, montagem paralela, geometrização, e anticronologia - os quais chamariam atenção para si mesmos; sua arte procede de maneira indireta, por alusão, elipse, e elisão [...]. Um filme de Bresson se desenvolve com tanta retórica formal quanto o vanguardista mais radical. Mas ele se concentra nas figuras cinematográficas que produzem uma sensação de fluidez e condensação e evita rupturas e interjeições bruscas. ${ }^{148}$
\end{abstract}

Tanto Bazin como Sitney parecem se referir a um mesmo tópico do estilo de Bresson quando comentam, por um lado, a presença concreta dos objetos, o fato de estarem alheios e indiferentes à situação (o que Bazin chama de "o concreto integral"), e por outro, o isolamento, através de planos próximos, dos gestos como detalhes ritualizados (o que Sitney chama de "moléculas narrativas"). Ambos comentam a autonomia dos planos, o fato de cada plano definir uma área no espaço e tempo na qual presenciamos eventos que parecem "puros", isolados, mas que por seu direcionamento e integração se tornam partes de uma mesma narrativa.

\footnotetext{
${ }^{147}$ Ibid., p. 186.

${ }^{148}$ Ibid.
} 
Bazin aponta o que esses planos possuem de concreto, em sua preferência pelo que eles nos revelam de uma realidade cuja infinita complexidade Bresson não se atreve a tocar diretamente, apenas conduzir - ainda que não haja semelhança composicional entre os filmes, encontramos aqui o mesmo ponto que vimos no exemplo dos Lumière. Sitney aponta o que esses planos possuem de abstrato, o que eles revelam da própria estrutura envolvida em sua apresentação, na coreografia delimitada pelo quadro e organizada no espaço cênico - ou seja, os aspectos que vimos no filme de Richter. Mas Bazin reconhece que a condução por parte de Bresson ocorre através da fragmentação dessa realidade, do diálogo constante entre imagem e som, e com um afastamento da "riqueza descritiva" do livro de Bernanos: o real é fragmentado, abstraído, para só então ser sintetizado em uma nova unidade pela necessidade interna da narrativa. ${ }^{149}$ Sitney, por sua vez, reconhece que a passagem se dá dos mecanismos formais ao "sentido de destino" inerente à narrativa. Há uma retórica, mas as figuras utilizadas por Bresson produzem justamente a noção de um fluxo, de uma unidade condensada: a forma é dispersa, mas a linearização da metonímia é o que permite que sob ela seja percebida uma mesma cadeia de eventos, atraídos para um único fim.

\section{O traçado das coordenadas}

A tendência realista como defendida por Bazin parece ser uma hipóstase do princípio centrífugo do quadro. Tanto a organização espacial num mesmo enquadramento como a organização temporal numa cena devem seguir essa característica, eventualmente levando à formação de um relato, um olhar sobre um mundo concebido a priori. A importância dada aos fatores sociais em torno do cinema - a natureza econômica da arte, bem como o contexto no qual a psicologia dos personagens é reconhecida - parece um dos sentidos desse princípio, assim como sua preferência pela definição do cinema por algo que não é o cinema. $\mathrm{O}$ valor documental e a dificuldade de separar o roteiro do terreno social no qual se enraizou é uma das razões para sua defesa do neorrealismo. ${ }^{150}$ As técnicas que interferem na unidade do real podem assim ser concebidas como

\footnotetext{
${ }^{149}$ Cf. Bazin, "O realismo cinematográfico e a escola italiana da Liberação”, Op. cit., pp. 291-292.

${ }^{150}$ Cf. Bazin, "Ladrões de Bicicleta", in Op. cit., p. 326. "Não há mais atores, não há mais história, não há mais mise en scène, vale dizer, enfim, na ilusão estética perfeita da realidade: não há mais cinema."
} 
ferramentas para atingir, por meios talvez mais complexos ou indiretos, essa realidade que se estende para além da tela. $\mathrm{O}$ contraponto entre som e imagem no filme de Bresson é um exemplo de utilização realista que difere daquela temida por Eisenstein: o som acrescenta à imagem, e vice-versa, mas o resultado dessa soma é uma afirmação ainda mais sugestiva da realidade.

A tendência formalista como defendida por Frampton talvez possua uma relação semelhante com o princípio centrípeto do quadro, ou pelo menos com o que ele chamou de seu aspecto metafórico. A presença dos objetos só é afirmada na medida em que é reconhecida a forma que a conduz na composição, tornando ambígua a referência a uma realidade integrada e externa (e, em casos mais extremos, como em Richter, tornando essa referência praticamente irrelevante). O quadro é acima de tudo um espaço icônico, um tabuleiro no qual as peças da consciência realizam seus movimentos. Disso resulta uma postura que, nas palavras de Frampton, busca "eliminar as suposições, eliminar o automatismo, eliminar a ideia, a suspeita, de que a 'cultura' é responsável pelo filme". ${ }^{151}$

O realismo, nesse sentido, parece partir do que há de mais específico nos objetos, indo de sua presença (ontologicamente afirmada), e sua localização no espaçotempo, até a adequação de sua aparência às necessidades do contexto social. $\mathrm{O}$ formalismo, em seu estado mais "puro", partiria, assim, do que há de mais geral nos objetos, colocando-os como algo à parte daquela realidade pressuposta, dando prioridade à autonomia de seus aspectos formais, mas eventualmente afirmando a correspondência entre as formas e os materiais - entre o espaço concreto da película e o espaço imaginado, criado pelas relações propostas. O realismo parece ir do específico ao geral; o formalismo, do geral ao específico.

Ainda que os primeiros exemplos - Lumière e Richter - parecessem incomunicáveis, representantes de duas visões completamente incongruentes, vimos que a aproximação gradativa das concepções de Bazin e Frampton pode revelar pontos ambíguos e dar espaço para análises que consideram o campo do cinema além de suas perspectivas particulares, ainda que indiretamente. Foi essa dupla aproximação, essa abordagem das obras por duas direções diferentes, que tivemos como objetivo, como ponto final desta primeira parte da dissertação: a busca por uma área do espectro onde

${ }^{151}$ Frampton apud Sitney, Eyes Upside Down: Visionary Filmmakers and the Heritage of Emerson (Oxford University Press, 2008), p. 111. 
os caminhos realizados a partir dos dois pólos, das duas idealizações, finalmente se cruzariam, e a delimitação dos fatores seria menos estrita. E é a investigação dessa área, a partir de outras referências, que veremos no capítulo seguinte, com a inclusão de autores e cineastas que de certa forma orbitaram em torno de (ou próximos a) Bazin e Frampton. Será feita então uma tentativa de amplificação da operação realizada neste capítulo, um acréscimo de camadas, o que eventualmente irá resultar na revelação de algumas das complexidades que podem ser encontradas em cada vertente, e consequentemente, que podem surgir em novas aproximações e diálogos entre elas. 
IV.

\section{A INFLUÊNCIA DE BAZIN E OS CONTEMPORÂNEOS DE FRAMPTON}




\section{Do cinema total às propriedades da mise en scène}

No prefácio de sua coletânea de ensaios sobre Bazin, Dudley Andrew comenta que a "linhagem Cahiers, como Serge Daney uma vez a descreveu, não é perfeitamente reta e nem singular (tendo várias ramificações), não sendo nem mesmo restrita a esta publicação". Ele se refere à geração de críticos que teve sua presença reforçada a partir de meados dos anos 50 na França, e que ditou grande parte dos termos para as discussões sobre cinema no período. É precisamente a influência de Bazin, um dos fundadores e editores da revista, que Andrew diz ser o arco que sustenta as mais diversas orientações. O que diferentes autores devem a ele pode ser identificado em três frentes: a definição do realismo no cinema como algo encontrado além da reprodução do movimento, ou ainda da superfície das imagens; um interesse no jogo entre a espontaneidade dos elementos da realidade e as diferentes "vozes" articuladas pelo cineasta em torno dela; as influências e consequências sociais dos discursos que são realizados pelos filmes e pela crítica. ${ }^{152}$

Esses tópicos, como vimos, compreendem uma área extensa das ideias de Bazin, revelando os próprios pontos de referência em sua obra, os centros de gravidade de suas preocupações. A concepção de uma dimensão do realismo que estaria além da reprodução sensorial é vista desde sua idealização do mito do cinema total até sua defesa das qualidades fotográficas e da superioridade ontológica do cinema sobre as outras artes. A inevitabilidade da articulação técnica da realidade, as abstrações necessárias para a condução da obra pelo cineasta, e as maneiras pelas quais essas intervenções podem levar a resultados positivos segundo sua ótica, também recebem atenção, especialmente em suas abordagens dos cineastas que considerava mais aptos ao desenvolvimento do realismo. O mesmo vale para o caráter do cinema como uma arte que não é definida por sua pureza, por sua autonomia técnica, mas pela adequação à realidade em todas as suas condições, dos fatores socioeconômicos aos fatores físicos de seus elementos. O que alguns desses autores levam adiante é uma amplificação das ideias de Bazin em diferentes direções, expandindo ou contraindo algumas de suas propriedades, intensificando ou enfraquecendo alguns de seus aspectos; de acordo com

${ }^{152}$ Andrew, “A Binocular Preface”, in Opening Bazin, p. X. 
a ocasião, o gosto e o modo como interpretam os mesmos tópicos, eles estendem e ramificam o arcabouço teórico de Bazin, realizando algumas de suas potencialidades enquanto outras são negadas ou restritas.

Os nomes centrais na ascensão dos Cahiers du Cinéma eventualmente passaram por outras revistas - como Andrew lembra, esta funciona mais como o ponto de cruzamento, o lugar em que diferentes trajetórias se aproximaram. ${ }^{153}$ Algumas das questões que tomaram conta dos Cahiers na década de 50 já se encontravam na Revue du Cinéma da década anterior, revista da qual Bazin fazia parte, e se estenderam à Présence du Cinéma até meados dos anos 60. O que toma corpo nessas publicações é uma posição que busca definir mais claramente o terreno no qual são postos em discussão dois tópicos: a noção de autor e o conceito de mise en scène. $\mathrm{O}$ autor, em termos gerais, seria nada mais que a consideração de um cineasta como o criador de sua obra, na mesma medida que um poeta ou pintor, pois realiza com ela uma composição, certa expressão de valores individuais através de escolhas formais. A mise en scène é o método a ser articulado pelo autor; um conceito derivado do teatro que implica uma visão realista e que, como veremos, dá margem para uma intervenção mais proeminente sobre a realidade, em comparação às preferências de Bazin. "O que importa num filme”, nesse caso, como descreve Hillier, "é o desejo por ordem, composição, harmonia, a disposição dos atores, os movimentos dentro do quadro, a captura de um movimento ou olhar; em resumo, a operação intelectual que colocou a emoção inicial e a idéia geral na obra". 154

A ênfase na figura do autor é um dos pontos de discordância entre Bazin e alguns desses críticos. Se para ele o real deve ser revelado apesar do artista, se esse processo é análogo a uma lei natural, e se existem necessidades internas mesmo numa narrativa composta e ordenada, então a ênfase não deve ser no autor, mas sim na obra, que é onde ocorre essa revelação. Bazin reconhece a importância do estilo, mas atenta para o que, sob seu ponto de vista, acabaria se tornando um "culto de personalidade estético". ${ }^{155}$ A concepção de mise en scène possui mais pontos em comum com o

${ }^{153}$ Para uma descrição e discussão da importância dos dois tópicos, ver a introdução de Jim Hillier, Cahiers du Cinéma - The 1950s: Neo-Realism, Hollywood, New Wave (Harvard University Press, 1985), pp. 5-11.

${ }^{154}$ Para um apanhado histórico da terminologia e das influências do teatro no conceito de mise en scène no cinema, ver a primeira parte de Jacques Aumont, O Cinema e a Encenação (Lisboa: Textos \& Grafia, 2006).

${ }^{155} \mathrm{O}$ argumento de Bazin é desenvolvido em "On the politique des auteurs", in Hillier, Op. cit., p. 249251. Originalmente em Cahiers du Cinéma, no 70, abril de 1957. 
pensamento de Bazin, sendo essencialmente uma extensão de suas ideias; mas ao estreitar alguns ângulos dessa postura, ao intensificar o olhar sobre algumas preocupações, o que decorre é uma gradual alteração - ainda que sutil - das áreas de interesse.

Serão considerados aqui Éric Rohmer, Jacques Rivette, Alexandre Astruc e Michel Mourlet. Com exceção de Mourlet, os outros fizeram a passagem da crítica à realização, o que é em si um dado importante. A geração da Nouvelle Vague é célebre pela forte consciência da história e crítica do cinema, e essa passagem é às vezes vista como um passo quase inevitável - é este o sentido do comentário de Godard, de que enquanto escreviam suas críticas, já faziam cinema. ${ }^{156}$ Como o objetivo é investigar algumas das ramificações do pensamento de Bazin através de comentários críticos e exemplos fílmicos, foi dada preferência àqueles que estabelecem um diálogo tanto a nível local como no contexto geral da dissertação.

\section{A respiração da realidade}

Éric Rohmer interpreta a importância da objetividade fotográfica na obra de Bazin como a ideia central da qual todas as outras derivam. Ele faz a comparação com a importância das propriedades da linha reta na geometria euclidiana: é tratada como um axioma, uma proposição auto-evidente que deve ser aceita para que todo o sistema seja desenvolvido. $^{157}$

A descrição de Bazin para a história da arte e para a alteração das condições desta com o surgimento do cinema sofre um leve desvio na terminologia através de Rohmer. Bazin se refere constantemente à representação da realidade pelo cinema, colocando sua objetividade como a natureza desejável no processo; Rohmer, se aproximando de uma tradição classicista, reconhece uma qualidade mais específica que ele chama de "beleza" como o fim da representação.

\footnotetext{
${ }^{156}$ Cf. "Interview with Jean-Luc Godard", in Tom Milne (ed.), Godard on Godard (Nova York: Da Capo, 1985), p. 171. "Frequentar cineclubes e a Cinemateca já era uma maneira de pensar cinema e pensar sobre o cinema. Escrever já era uma maneira de fazer filmes, pois a diferença entre escrever e dirigir é quantitativa e não qualitativa."

157 Cf. Éric Rohmer, “André Bazin's Summa”, in The Taste for Beauty (Cambridge University Press, 1989), p. 95. Originalmente em Cahiers du Cinéma, no 91, janeiro de 1959.
} 
A pintura, a poesia, a música [...] tentam traduzir a verdade através de sua intermediária, a beleza, que é o seu domínio, o qual elas não podem abandonar sem deixarem de existir. O cinema, por outro lado, usa técnicas que são instrumentos de reprodução ou, podemos dizer, de conhecimento. Nesse sentido, possui a verdade desde o início e busca fazer da beleza seu fim supremo. Uma beleza, então, e esse é o ponto fundamental, que não é sua própria, mas da natureza. Uma beleza que tem a missão de descobrir, e não de inventar, de capturar como uma presa, de praticamente abstraí-la das coisas. ${ }^{158}$

Beleza, verdade, conhecimento: esta tríade tem um papel importante nos desdobramentos do pensamento de Bazin entre os autores dos Cahiers du Cinéma. O que Rohmer enfatiza é o fato de a beleza já se encontrar no mundo, numa espécie de reformulação da crença de Bazin na ambiguidade fundamental do real. Mas principalmente, o que temos é uma continuação da postura que vê as belas-artes como partindo de uma idealização da natureza. Existem regras a serem seguidas pela pintura, pela poesia e pela música; existem escalas, uma métrica verbal, uma geometria espacial, que servem como referências e filtros sobre a realidade apresentada; o músico, o pintor e o poeta devem atravessar um campo idealizado, e nesse processo sua obra se torna uma representação indireta da natureza. Se a objetividade fotográfica é considerada como o ponto de partida do cinema, aquilo que garante sua ligação direta com essa natureza, o cineasta não deve cobri-la ou desviá-la com manipulações, mas manter sua transparência. A beleza não deve surgir da intervenção, mas do que é apreendido; o cineasta deve "descobrir, não inventar". A condenação ao excesso de interpretação, que faz eco à ligação entre cinema e realidade como no cinema total de Bazin, é resumida por Rohmer: "Nascida do mundo, [a arte] deve nos levar de volta a ele". ${ }^{159}$ Uma concordância à qual Rohmer acrescenta alguns pontos, em textos que lidam com diferentes aspectos envolvidos na composição dos filmes, tornando cada vez mais específico seu posicionamento.

Bazin diz que a realidade do espaço é a única da qual não podemos privar o cinema, sendo o mais próximo do que podemos chamar de uma característica específica

\footnotetext{
${ }^{158}$ Rohmer, "The taste for beauty", in Op. cit., pp. 75-76. Originalmente em Cahiers du Cinéma, no 121, julho de 1961.

159 Rohmer, "Such vanity is painting", in Op. cit., p. 44. Originalmente em Cahiers du Cinéma, no 3, junho de 1951.
} 
desta arte. Em um primeiro momento a afirmação pode soar ambígua, visto que Bazin também reconhece no cinema a consecução temporal da fotografia como uma característica fundamental. Rohmer se aproxima da questão e argumenta que o cinema seria uma arte do espaço mais do que uma arte do tempo. ${ }^{160}$ Em primeiro lugar, é a arte do movimento por excelência, devendo organizar esses movimentos através de uma hierarquia de significados - estabelecer um conceito geral, o que remete à noção de Dulac para os movimentos "essenciais", em lugar da "pura agitação". Em segundo lugar, é uma arte visual, de modo que o movimento é percebido apenas através de uma sensibilidade propriamente espacial. Mesmo a técnica de apresentar diferentes planos em sequência pode ajudar a reforçar a natureza expressiva de cada um deles, e sugerir trajetórias e outros movimentos que se estendam além do campo de visão. Dessa forma, o ritmo particular de cada plano pode ser integrado em um ritmo geral, que inclui todos sob um mesmo princípio.

O que Rohmer parece defender é que, ainda que o tempo esteja implicado e tenha um papel importante, não deve ser privilegiado. $O$ fator-guia no interior de um plano e na concepção de uma sequência de planos deve ser o espaço, pois é nele que está inscrita a ligação entre o cinema e a realidade. Por essa razão, a combinação de diferentes planos tendo em vista um direcionamento específico não deve levar em conta apenas seu ritmo superficial - sua duração e movimentação particulares -, mas o quanto destes componentes contribui para o movimento geral da sequência. Este ponto retoma a crítica de Bazin à imposição de um ritmo externo, que mais à frente veremos ser condenada também por Mourlet.

Essa dependência do espaço, ou ainda, essa definição do desenvolvimento temporal através do espaço, é exemplificada no elogio de Rohmer a uma cena de caça de Nanook, o Esquimó (Nanook of the North, Robert Flaherty, 1922) em que o personagem-título é mostrado no canto do quadro, esperando as focas na praia. ${ }^{161} \mathrm{O}$ que Rohmer diz tornar a cena bela não se deve ao ponto de vista da câmera, ao enquadramento, ou mesmo à expressividade dos gestos (ou seja, nenhum dos procedimentos interpretativos, pictóricos ou cênicos), e sim ao mistério criado pela ansiedade, a tensão crescente que decorre da espera pela ação. A continuidade do plano é crucial, assim como a presença concreta de Nanook e das focas, e sua inserção num

\footnotetext{
${ }^{160}$ Rohmer, "Cinema, the art of space", in Op. cit., pp. 19-21.

161 Rohmer, "Such vanity is painting", Op. cit., p. 46.
} 
espaço homogêneo. Uma fotografia entregaria a configuração espacial congelada; um romance descreveria a espera ao mesmo tempo em que exigiria nossa participação em sua constituição; é apenas com a observação do evento em seu desenvolvimento natural, de sua duração encarnada, que nos tornamos verdadeiras testemunhas e a beleza é alcançada.

O tempo, então, através do espaço. Se o cinema é uma arte realista, tudo está em processo de vir-a-ser, e o movimento é um de seus fundamentos, a própria condição para encontrar a beleza. "Um rosto importa pouco, até que relaxa ou estremece segundo seus ritmos internos. Folhas importam pouco, até que criam beleza ao serem sopradas. O cinema trabalha com o movimento, em que o único domínio deve ser abstrair e reconstruir". ${ }^{162}$ Esse movimento é a manifestação do princípio orgânico ao qual Bazin se refere constantemente. ${ }^{163}$

Sobre as diferentes maneiras pelas quais o movimento adquire sentido, podemos nos voltar para a comparação que Rohmer estabelece entre as possibilidades cômicas do movimento em Chaplin e em Buster Keaton. ${ }^{164}$ Os melhores momentos de Chaplin, segundo Rohmer, não constituem uma comédia do "puro movimento", pois os movimentos surgem de um fluxo emocional, que expressam e transfiguram, mas do qual também derivam seu sentido. O espaço, nesse caso, é o meio mais conveniente para significar, mas não é em si um criador de significado. Em Keaton, por outro lado, encontraríamos a comédia do puro movimento, o significado do espaço em si, e não de sua psicologia. Rohmer cita uma cena de Boxe por Amor (Battling Butler, 1926) em que Keaton, interpretando um boxeador novato, tenta em vão recriar um golpe ensinado por seu treinador. O ridículo da situação não seria desenvolvido se não houvesse, através da repetição do gesto, um questionamento do espaço e da própria disposição dos corpos nas três dimensões. Outro exemplo seria uma cena posterior, em que seu personagem fica preso nas cordas ao tentar entrar no ringue. O tom cômico das cenas resulta da inadequação de Keaton, da irregularidade de suas ações dentro de um referencial regular.

\footnotetext{
162 Rohmer, "Reflections on color", in Op. cit., p. 40.

163 Cf. Henri Bergson, Creative Evolution (Nova York: Modern Library, 1944), pp. 296-297. Bergson se refere a uma filosofia "que vê na duração a própria matéria da realidade". Ele defende que a percepção como um todo se processa como o aparato cinematográfico, apreendendo imagens isoladas enquanto as integra num mesmo direcionamento, refletindo as características internas da matéria.

164 Rohmer, "Cinema, the art of space", Op. cit., pp. 22-23.
} 
Esse conflito é o que Rohmer descreve como sendo o aspecto kafkiano em Keaton: uma visão de mundo naturalmente rigorosa e geométrica, com uma solidão que não é aquela de Chaplin (a de uma sociedade indiferente ao homem), mas uma em que os corpos parecem isolados por uma condição intrínseca ao espaço. Hugh Kenner descreve a relação entre os dois cineastas em termos semelhantes:

Foi à natureza das coisas que [Keaton] se opôs, e nunca se pode superar esse adversário; pode-se apenas continuar o movimento, apenas ser bem sucedido em não ser privado da própria mobilidade [...]. Os adversários de Chaplin, por outro lado, eram grandes malevolências estáticas, carnudas, com olhos de porco, geralmente barbudos e bloqueando o caminho entre Chaplin e seu desejo simples: uma refeição, uma garota. Acertados na cabeça inúmeras vezes, eles não desistiam, mas quando caíam, e eventualmente sempre caíam, era por causa de seu próprio peso. A lei da gravidade era a aliada de Chaplin. Era a nêmese de Keaton. ${ }^{165}$

Podemos descrever essas duas modalidades como sendo a do movimento como um meio (Chaplin) e a do movimento como um fim (Keaton). Na primeira há uma psicologia anterior ao gesto, que o inclui num nexo de significados e submete sua qualidade puramente física a um processo formado pelas situações em que se encontra como a tendência do romance descrita por Kenner, em que os personagens funcionam como "energias", guiadas pela verossimilhança e plausibilidade. Na segunda, há uma ênfase no próprio caráter do movimento enquanto tal, a percepção de suas coordenadas imediatas, um sentido que não se encontrava naquela situação ou naquela narrativa em primeiro lugar.

Esta distinção é importante nos textos de Rohmer, sendo retomada em comentários sobre outros elementos, como o diálogo e a cor. Ele diz, da mesma forma, que o diálogo pode servir a uma lógica externa, criando um significado que deriva da configuração da cena, ou pode acrescentar, por sua própria dimensão sonora, um novo significado. Rohmer defende que a disposição sonora do diálogo foi privilegiada no início do cinema, e que o discurso foi deixado em segundo plano: o diálogo era um som antes de ser um signo. Ele justifica sua preferência por Soberba sob o argumento de que, enquanto Cidadão Kane possui um tratamento radiofônico das falas (o som como

\footnotetext{
${ }^{165}$ Kenner, “Buster Keaton: In Memorian”, in Mazes (São Francisco: North Point, 1989), pp. 300-301.
} 
"puro som"), Soberba as coloca primeiramente como um modo de revelar o interior dos personagens. A cena da cozinha analisada por Bazin é exemplar nesse sentido: assim como os cortes quebrariam a unidade espacial, quebrariam também o fundo silencioso contínuo sobre o qual surgem as falas, que são a manifestação direta da teimosia dos personagens e em que a interjeição de Fanny surge como um ponto crítico. ${ }^{166}$

Em relação ao uso das cores, as mesmas distinções são apontadas. No primeiro tipo, a cor é um ornamento adicional, ou uma necessidade temática; ela toca, sublinha e até substancia a textura dramática, mas nunca é sua fonte. No segundo, a cor tem o poder de um detalhe que cria um clima próprio. Como exemplos deste segundo uso, Rohmer cita o vestido azul de Harriet (Patricia Walters) em O Rio Sagrado (The River, Jean Renoir, 1955) e o vestido verde da solitária ("Miss Lonelyhearts”, Judith Evelyn) em Janela Indiscreta (Rear Window, Alfred Hitchcock, 1954). Em Um Corpo que Cai (Vertigo, Alfred Hitchcock, 1958), a luz esverdeada na cena em que Scottie (James Stewart) testemunha o "renascimento" de Madeleine (Kim Novak) ao vê-la surgir com a mesma aparência da mulher que ele acredita ter falecido, é um exemplo de multiplicação do efeito dramático através do surgimento de uma cor que até então não se encontrava tão presente no filme, e que é apreendida sensivelmente no quadro como a atmosfera na qual a personagem se encontra (nesta cena em particular é de fato algo como uma atmosfera, algo puramente luminoso, em contraste com a cena em que Scottie observa Madeleine no restaurante, onde as paredes vermelhas preenchem quase todo o quadro, mas afirmam sua materialidade e proximidade com o lado "quente" do espectro). ${ }^{167}$ Nesses casos, a cor seria a matéria sensível da realidade, cuja forma precede o sentido - "o céu é azul antes de ser céu". 168

Rohmer parece valorizar as duas modalidades, ainda que no texto sobre Keaton demonstre um apreço por sua originalidade, o que provavelmente decorre do papel central dado ao movimento como função do espaço. Em relação à cor e ao diálogo, sua preferência parece ser pelo caráter autônomo, desde que este seja integrado ao drama -

\footnotetext{
166 Rohmer, "For a talking cinema", in Op. cit., pp. 29-30. .

167 Cf. Johann Wolfgang von Goethe, Theory of Colors (Londres: William Clower, 1840), p. 316. Goethe comenta como o fato de o verde resultar da união entre o amarelo e o azul - as duas cores que ele aponta como sendo "as mais fundamentais e simples", cada uma delas direcionadas para um extremo do espectro - faz com que nas colorações esverdeadas haja uma espécie de repouso para o olho, um equilíbrio em que nem a luz e nem a sombra predominam. Num sentido análogo, o uso do verde por Hitchcock reforça não apenas o equilíbrio entre os extremos cromáticos, mas a própria harmonia momentânea do drama, a convergência entre o desejo de Scottie e a imagem concreta à sua frente.

168 Rohmer, "Of taste and colors", in Op. cit., p. 68.
} 
o valor da cor enquanto cor, como um elemento que acrescenta por sua própria condição cromática, mas que também realiza uma contribuição dramática; da mesma forma, o diálogo é elogiado quando sua expressividade puramente sonora é adequada à revelação psicológica. Ao tomar a definição de Bazin como um axioma, Romer se torna também um tributário do mito do cinema total no sentido de que, sejam quais forem os elementos ao redor da objetividade fotográfica, eles devem ser incluídos num sentido geral de composição, e não aceitos como uma simples adição. A reprodução das características da realidade é apenas o ponto de partida; a beleza, para que seja descoberta nessa realidade, necessita de uma abstração, de uma síntese, portanto da submissão das características superficiais, puramente sensoriais, à concepção geral do filme.

Naturalmente, Rohmer não é a favor de uma abordagem linguística do cinema, de um método de montagem como sugerido por Eisenstein, ou de qualquer sistema préestabelecido. Ele diz estar de acordo com Pasolini quanto ao fato de a "linguagem cinematográfica" ser, na verdade, um estilo. "Não existe uma gramática cinematográfica, mas antes uma retórica que, ademais, por uma parte é extremamente pobre e por outra extremamente mutável". ${ }^{169}$ Parece haver a aceitação de uma área comum, na qual diferentes perspectivas se encontram (os diferentes estilos), mas não a possibilidade de um método central e sistemático para abordar a realidade. Este é o ponto principal: se o objetivo do cinema é abordar a realidade, ela deve ser pressuposta, e o número de abordagens é limitado por suas condições - mas não as limitações de um esquema, como na decupagem analítica, que enfatiza justamente o recorte e a reordenação da realidade.

Neste ponto podemos fazer uma comparação com o ideal de Frampton, que também não considera que o cinema se encaixe num esquema propriamente linguístico, mas propõe a existência de um esquema análogo. A diferença parece se dar na aspiração por um método que tome controle desses fatores, o que Rohmer não acredita ser possível. A beleza para ele está na realidade integrada, e deve ser entrevista pela continuidade espacial, e da sujeição das cores, sons e movimentos aos princípios que os "retornam" à realidade de maneira sintética. ${ }_{169}$ Rohmer, "The Old and the New", in Op. cit., pp. 84-85. Originalmente em Cahiers du Cinéma, no
172, novembro de 1965. 
Alguns dos filmes de Rohmer exploram essas preocupações, e encontramos em seus próprios comentários uma evidente unidade de pensamento, uma extensão de seus textos. Entre 1962 e 1972, ele realiza um ciclo de filmes que denomina "contos morais", todos compartilhando uma mesma premissa narrativa: um homem é atraído por uma mulher enquanto está prestes a firmar um relacionamento com outra. Essa estrutura é conscientemente derivada de Aurora (Sunrise, F.W. Murnau, 1926), de modo que talvez possamos retomar o termo de Kenner e chamar cada um dos contos de Rohmer de homeomórficos com o de Murnau - ou, nos termos de Frampton, de diferentes demonstrações de uma mesma equação.

A manutenção dessa forma fixa é crucial na construção dos filmes, pois é através dela que Rohmer parece se libertar das preocupações analíticas da narrativa (a tendência a ter o filme como consequência de uma psicologia anterior a ele) e se voltar mais diretamente para as qualidades comentadas em seus textos. É nesse ponto que a influência de Bazin se mostra especialmente frutífera, na maneira como Rohmer se dedica à afirmação da presença concreta das pessoas e cenários, da unidade subjacente aos aspectos sensíveis, e da organicidade da narrativa através de um jogo psicológico com influências romanescas. É dentro desses limites que Rohmer se põe a jogar com os elementos:

\footnotetext{
Como um músico, eu vario o motivo inicial, reduzo ou aumento sua velocidade, estico ou encolho, acrescento ou purifico. [...] O personagem principal, por exemplo, é um puritano num conto (Minha Noite com Ela), um libertino em outros (A Colecionadora, $O$ Joelho de Claire), às vezes frio, às vezes exuberante, às vezes mais inocente, às vezes astuto. ${ }^{170}$
}

Nos contos morais, as pessoas falam sobre coisas que devem ser mostradas com toda a precisão possível pela imagem para que dialoguem com as fronteiras psicológicas da narrativa: falam da magreza, da fragilidade, da suavidade do joelho que exerce uma atração sobre o protagonista. Como em sua defesa do diálogo, a linguagem é utilizada para se referir ao mundo; vindo dele, retornando a ele, passando por ele. Rohmer enfatiza o poder do cinema de evocar o ambiente em torno dessas características, dos efeitos de luz em uma hora particular do dia ou de uma estação, das sensações de calor,

${ }^{170}$ Rohmer, "Letter to a critic", in Hillier, Op. cit., p. 81. 
de frio, a secura e a umidade. ${ }^{171} \mathrm{O}$ brilho dourado e o som das ondas em $A$ Colecionadora (La collectioneuse, 1967) ou a luz difusa e a neve em Minha Noite Com Ela (Ma nuit chez Maud, 1969) são elementos narrativos, com um sentido próprio no contexto dramático, ao mesmo tempo em que complementam, quando não refletem, a psicologia dos personagens. Não por acaso, Rohmer deu sequência aos contos morais com um ciclo de filmes baseado nas quatro estações. É evidente seu interesse nessas qualidades sensíveis, na apreensão de propriedades da matéria em seu contexto natural, e em como a passagem de personagens sobre determinados espaços faz com que essas propriedades pareçam funcionar como uma espécie de ressonância interna daquele universo - como que em eco à descrição de Bazin para o som no cinema de Bresson.

Em grande parte dos filmes de Rohmer parece haver menos foco narrativo que em Bresson, ou mesmo Rossellini - como se os "mecanismos" da trama devessem ser mantidos em segundo plano. Por um lado, a escolha dos enquadramentos é sempre direta; não surgem dúvidas sobre o que está em jogo na frente da câmera, e o que está em jogo é sempre um drama humano, geralmente expresso com vários níveis de eloquência pelos personagens. Mas o núcleo efêmero que parecia se situar por trás da imagem nas vistas dos Lumière (que eram, afinal, uma única imagem concentrada), o princípio geral que parecia organizar toda a natureza numa mesma unidade, aqui parece se encontrar em algum lugar entre os personagens, entre as cenas, integrando o mundo por sua psicologia sem defini-lo por operações "puramente" fílmicas - o que parece refletir-se na leveza com que Rohmer conduz suas narrativas, a atenção ao que aquilo possui de construção temperada pela receptividade ao que invade essa construção pela abertura à realidade.

A câmera nunca está muito distante das pessoas (ou não veríamos suas expressões, os detalhes de seus gestos), mas também nunca se aproxima demais (ou não veríamos o cenário que as cerca). Sempre há uma distância média; sempre ocorrem movimentos breves, especialmente panorâmicas que descrevem o espaço ao mesmo tempo em que acompanham os personagens (a câmera não se move independente dessas ações). O som é quase sempre direto, mas Rohmer não permite que se torne uma cacofonia; há sempre uma seleção, uma ordenação ou depuração desses sons, como ocorre com as imagens, mas não há um destaque para esses ruídos. A técnica de Rohmer é constante em sua simplicidade; o esquema, se é que podemos chamar assim o

${ }^{171}$ Cf. Ibid., p. 83 
conjunto de procedimentos que ele utiliza, parece funcionar, como na arte clássica, como a grade pela qual a realidade respira. É por essa razão que o caráter documental, o aspecto vagamente desordenado e surpreendente dos eventos é constantemente presente: a ficção respira o documentário.

\title{
II. A oscilação entre ordem e acaso
}

Jacques Rivette alia a ontologia fotográfica de Bazin ao juízo de valor em seu texto sobre Howard Hawks, cujo gênio ele afirma residir na "evidência". A evidência, no caso, da própria realidade sensível, que, assim como nos textos de Rohmer, é exaltada por seu fator a um só tempo dinâmico e natural, "uma beleza que demonstra a existência pela respiração e o movimento pelo caminhar". ${ }^{172}$

O que Rivette elogia em Hawks é um certo pragmatismo que não apenas suporta e afirma a matéria concreta pela ausência de "expressividade", mas que a conduz de maneira eficaz. A fisicalidade das coisas, por um olhar firme e direto sobre as aparências, é considerada junto de uma funcionalidade que determina seu sentido.

\begin{abstract}
Não estamos preocupados com os pensamentos de John Wayne quando ele anda até Montgomery Clift no final de Rio Vermelho, ou os pensamentos de Bogart enquanto ele bate em alguém: nossa atenção é direcionada unicamente para a precisão de cada passo - o ritmo exato da caminhada - de cada golpe - e o colapso gradual do corpo cansado. Ao mesmo tempo [...] um ato prende nossa atenção não tanto por sua beleza intrínseca, mas por seu efeito no funcionamento interno de seu universo. ${ }^{173}$
\end{abstract}

Para que essa qualidade seja atingida, deve-se fazer um uso específico do espaço e do tempo, o que exclui algo como um flashback, essencialmente uma quebra na continuidade. Assim como na descrição da narrativa de Bazin, há uma preferência pela exigência "interna", e a "lei da montagem" aqui é tomada com seriedade absoluta. Rivette defende que a funcionalidade dos planos cria algo como uma pulsação, e que o

\footnotetext{
${ }^{172}$ Rivette, "The Genius of Howard Hawks", in Hillier, Op. cit., p. 126 e p. 131. Originalmente em Cahiers du Cinéma, $\mathrm{n}^{\circ}$ 23, maio de 1953.

${ }^{173}$ Ibid., p. 128.
} 
filme se forma como uma entidade orgânica. ${ }^{174}$ É característico que Rivette empregue o mesmo termo de Rohmer - "beleza" - para referir-se à integração dos movimentos ao conjunto geral que atrai nossa atenção.

O que encontramos nos filmes de Hawks é então a expressão necessária desses termos. O drama é representado espacialmente, pois é esta a realidade a ser respeitada. As variações do cenário são paralelas às variações temporais no decorrer da narrativa. Em Scarface (1932), por exemplo, o domínio do protagonista diminui gradualmente, passando de toda a cidade até a sala em que ele termina trancado; em Paraíso Infernal (Only Angels Have Wings, 1939), os aviadores presos na estação por causa da neblina são impedidos de escapar pelas montanhas, e a espera causada nesse cenário é o próprio tema das cenas.

A necessidade das leis internas também é válida para os atores. Mesmo que a restrição espacial os faça encarar, superficialmente, uma situação monótona, Rivette diz que por baixo dessa superfície deve haver um amadurecimento lento dos sentidos, que são desenvolvidos até o clímax:

Hawks usa a lentidão como um dispositivo dramático - para representar a
exasperação de homens que devem se restringir por duas horas, contendo
pacientemente a raiva, ódio ou amor perante nossos olhos, e então
repentinamente explodindo, como baterias lentamente saturadas, que
eventualmente estalam. ${ }^{175}$

Nesse sentido, Rivette subscreve às concepções de Bazin. Assim como Rohmer, ele não faz o elogio da pura superficialidade, da mera reprodução, mas de uma animação interior dos elementos, de uma integração objetiva, baseada nos contornos do visível, mas subjacente a ele. Há o reconhecimento da relação ontológica entre a representação e a própria organicidade da realidade, mas em seus textos ela é levada a um nível praticamente tautológico; diferente de Bazin, que buscava argumentar e encontrar paralelos em outras artes, Rivette afirma sua posição ao identificar o gênio de Hawks na "evidência". Isso se coloca mais claramente na frase que encerra o texto: "O que é, é’.

\footnotetext{
${ }^{174}$ Ibid., pp. 128-129.

175 Ibid., p. 129.
} 
Um comentário parecido é feito sobre Rossellini. Rivette diz que Rossellini não "demonstra" (não faz com que sua articulação seja o ponto de ligação com o espectador), ele "mostra" (apresenta as coisas "como elas são"). Assim como Bazin, o que Rivette reconhece em Rossellini é esse aspecto de uma realidade que parece não ser filtrada por uma sensibilidade que se impõe aos fatos. Se há uma imposição, é de outra ordem, aquela descrita por Tag Gallagher: a imposição do espaço visível, da presença única do cenário, do contexto, a definição da matéria e do trajeto dos personagens por uma topologia própria daquele momento. ${ }^{176}$

Ele descreve então algo como um procedimento típico no método de Rossellini:

Sobre a tela, uma longa parábola, maleável e precisa, guia e controla cada sequência, e então pontualmente a fecha novamente. Pense em qualquer filme de Rossellini: cada cena, cada episódio irá recorrer em sua memória não como uma sucessão de planos e composições, uma sucessão mais ou menos harmônica de imagens mais ou menos brilhantes, mas como uma vasta frase melódica, um arabesco contínuo, uma única linha implacável que guia pessoas inevitavelmente ao ainda desconhecido, abraçando em sua trajetória um universo palpitante e definitivo... ${ }^{177}$

Esta citação descreve de maneira sintética algumas das preocupações de Rivette, bem como de Rohmer e Bazin, e o interesse deles no cinema de Rossellini. Uma preferência pela liberdade construída, em que a construção desaparece sob o rascunho no decorrer dos eventos, em que mesmo as dispersões sugerem a unidade do movimento. As variações do evento, como na descrição da composição do filme dos Lumière, parecem mais uma espécie de dinamização do que a criação do mesmo; o olhar do cineasta mais um catalisador do que um gerador. Parece haver uma incompletude inerente ao respeito à realidade como defendido por Rivette, como encontramos na definição de Bazin para a tela e o espaço cênico. Essa incompletude, baseada no fato de que sempre há mais do que aquilo que é mostrado, é comentada por Aumont:

O interessante no cinema dos Lumière e, em geral, dos primeiros cineastas, é o fato de terem percebido intuitivamente que estavam imersos naquilo que iam

\footnotetext{
${ }^{176}$ Cf. Rivette, "Letter on Rossellini", in Hillier, Op. cit., p. 194. Originalmente em Cahiers du Cinéma, $\mathrm{n}^{\circ} 46$, abril de 1955 .

${ }^{177}$ Ibid.
} 
apresentar como espetáculo, como peixes na água; que faziam parte desse mundo que iam representar; que representavam apenas um dos pontos de vista dele e um instante infinitamente transitório; por conseguinte, que mostravam realmente o mundo e não apenas um retângulo de imagem recortada num dos seus aspectos momentâneos. ${ }^{178}$

Mas em Rivette encontramos também um interesse pelo inverso, por um olhar que busca o controle e a coordenação mais estrita de todos os elementos. Encontramos em seu texto sobre Suplício de uma Alma (Beyond a Reasonable Doubt), filme de 1956 dirigido por Fritz Lang. O filme conta a história da aliança entre Austin (Sidney Blackmer) e Tom (Dana Andrews) para revelar a falibilidade do sistema de justiça. Ambos concordam em plantar pistas e encenar situações para que a investigação de um crime leve até Tom, demonstrando assim que um inocente pode ser perfeitamente capturado pela teia policial. Rivette diz já no início do texto que, neste filme, "nenhuma concessão é feita ao detalhe". Tudo serve aos propósitos da trama: estamos num mundo de necessidade absoluta, em que o exame da arbitrariedade é o próprio alvo das ações dos personagens. "Lang sempre busca a verdade além do razoável", ele continua, "e aqui busca além da fronteira do irracional". ${ }^{179}$

O método de Lang é o oposto daquele descrito como sendo o de Rossellini, ou uma intensificação do que era visto em Hawks. Onde Rossellini teria uma "sucessão de melodias e linhas" que "guiam as pessoas ao ainda desconhecido", Lang se coloca como adepto de uma geometria rígida, tanto no desenho cênico como na estrutura narrativa. Essa rigidez não é de maneira alguma "expressiva", pelo contrário; o ponto levantado por Rivette é como um princípio geral para Lang, que parece determinar tudo segundo uma lógica que vê a narrativa como um sistema homeostático em que nada deve passar por seu filtro sem ser considerado. A rigidez do método é o caminho para uma transparência que, em vez de projetar uma organicidade no universo representado, de arejá-lo pela ausência de controle, termina por refleti-lo justamente pelo controle. $\mathrm{O}$ filme de Lang é um olhar sobre uma trama que é ela própria baseada na falsificação das aparências, dispondo os objetos nos espaços e efetuando as ligações necessárias da

\footnotetext{
178 Aumont, O Cinema e a Encenação, op. cit., p. 54.

179 Rivette, "The Hand", in Hillier, op. cit., p. 140. Originalmente em Cahiers du Cinéma, no 76, novembro de 1957.
} 
mesma forma que os personagens criam a trama da investigação. ${ }^{180}$ Ao ser tomado pela fagulha do acaso, o universo logo se vê transformado num labirinto onde Tom caminha sem liberdade ou segurança aparentes. A falha no plano reorganiza as expectativas a partir do momento em que cada nova surpresa deixa de ser apenas uma nova peça no quebra-cabeça, mas também uma nova possibilidade de resolução.

Essa postura de Lang, e a tensão constante que dela resulta, sugere para Rivette uma "negatividade" central na composição; não num sentido qualitativo, mas como uma operação que termina por atacar os próprios fundamentos. Em primeiro lugar, uma destruição das cenas, pois cada cena passa a ser tratada em si, como "momentos puros" em que a única coisa que permanece é seu aspecto mediador: "o que pode determinar ou atualizá-las mais concretamente não é abstraído ou suprimido - Lang não é Bresson mas desvalorizado ou reduzido à condição de pura referência espaço-temporal, desprovida de incorporação". E, em segundo lugar, uma destruição da interioridade dos personagens, pois cada um deles se torna nada mais do que a soma de seus gestos e palavras, nada mais do que o aquilo que falam e fazem. ${ }^{181}$

A chave de restrição utilizada por Lang parece realizar o processo oposto àquele reconhecido por Rivette em Rossellini. Uma chave fundada na causalidade, e que a coloca mesmo como uma força descomunal, uma regra geral de composição, suprimindo tanto a organicidade de Hawks como a parcela de indefinição de Rossellini. Essa elevação da causalidade a um princípio remete à denominação de Tom Gunning para o desenvolvimento das narrativas de Lang, o que ele chamou de máquinas de destino. ${ }^{182}$

Este é um ponto importante, pois vai de encontro ao que foi defendido por Bazin e que é identificado como o princípio realista que remonta ao filme dos Lumière, tanto pela expressão dos personagens como pela aparente liberdade das cenas. Reconhecendo

${ }^{180}$ O paradigma de controle na obra de Lang é Dr. Mabuse, o personagem no centro de três de seus filmes. Em cada um deles, Lang identifica Mabuse com algum aspecto da composição. O primeiro, Dr. Mabuse: O Jogador (Dr. Mabuse: Der Spieler, 1928) é silencioso, e a principal arma de Mabuse é seu olhar, com o qual hipnotiza outros personagens. No segundo, O Testamento do Dr. Mabuse (Das Testament des Dr. Mabuse, 1933), já no período sonoro, Mabuse é confinado num hospício, e mesmo após sua morte seus escritos influenciam os acontecimentos, inclusive através de uma voz gravada e reproduzida por um alto-falante. No terceiro, Os Mil Olhos do Dr. Mabuse (Die 1000 Augen des Dr. Mabuse, 1960), Mabuse já não existe fisicamente, mas seu nome é adotado e identificado com uma rede de observação e controle, com todo um aparato televisivo disposto num hotel.

181 Rivette, "The Hand", in Hillier, op. cit., p. 141.

182 A expressão é recorrente no livro de Gunning, The Films of Fritz Lang: Allegories of Vision and Modernity (Londres: British Film Institute, 2000). Gunning a desenvolve já nos primeiros capítulos, sobre o período mudo de Lang. 
a importância central de um método que segue a via oposta, Rivette pode parecer inicialmente interessado no controle puro e simples, na maior presença do cineasta como articulador da realidade. Mas, como veremos, seu interesse é voltado mais para a transparência que nega a articulação, que se torna uma só com a realidade - e acima de tudo, para como esse controle pode ser oposto ao inesperado.

O interesse de Rivette por essa oposição é mais claramente entendido através de sua eleição de Otto Preminger como a definição de cineasta que trabalha acima de tudo como um encenador. Enquanto Hawks e Lang "acreditariam primeiramente em seus temas", e construiriam suas respectivas artes sobre eles, Rivette diz que Preminger acredita acima de tudo na própria mise en scène, "na criação de um complexo preciso de cenários e personagens, uma rede de relações, uma arquitetura de conexões, um complexo animado que parece suspenso no espaço". Há aqui uma ênfase no aspecto cênico como o centro da composição, como a própria síntese do trabalho do cineasta - o que nos lembra da diferenciação de Rohmer para os elementos como podendo servir a uma psicologia ou acrescentando uma nova camada por sua autonomia. Preminger representa para Rivette a "pureza" da mise en scène no sentido de que constitui com ela um procedimento autônomo. ${ }^{183}$

Ele descreve mais diretamente o que estaria em jogo com essa abordagem: "No meio de um espaço dramático criado por encontros humanos, [Preminger] explora ao limite a habilidade do cinema de capturar o fortuito (mas um fortuito consciente), de registrar o acidental (mas um acidental criado) através da proximidade e definição do olhar". ${ }^{184}$ Um jogo, portanto, entre o controle e o acaso. A captura de algo já esperado, mas cuja efemeridade é crucial; o registro de algo que é preparado, mas espontâneo. Preminger parece oscilar entre os dois pólos, ou equilibrar a polaridade que Rivette reconhece entre Rossellini e Lang. Aumont comenta a metodologia usual de Preminger:

Preminger é, antes de tudo, o homem da fluidez, e o seu instrumento mais importante é o movimento de câmera. Para ele, uma cena é, antes de tudo, uma continuidade; se a puder filmar num único plano, fá-lo-á, tendo de determinar as trajetórias dos atores de forma a tornar isso possível; se tiver de planificar, recorrerá a ligações no movimento; o contracampo não lhe é estranho, mas

\footnotetext{
${ }^{183}$ Rivette, "The Essential", in Hillier, Op. cit., p. 134. Originalmente em Cahiers du Cinéma, no 32 , fevereiro de 1954.

${ }^{184}$ Ibid.
} 
apenas quando não é evitável e sempre como uma forma neutra que, por si mesma, não tem qualquer expressividade. O resultado, visível em qualquer dos filmes de maturidade de Preminger, é um forte sentimento de "direção", não no sentido de "direção de atores" [...], mas antes no sentido hitchcockiano da "direção de espectadores". Acompanhando, de forma ágil, mas exata, as deslocações das personagens e conservando sempre um certo grau de liberdade, e quase a sua arbitrariedade, a câmera dirige a minha atenção, quer eu queira quer não, de um gesto a outro, de um olhar a outro, de um ponto ao outro. ${ }^{185}$

Assim como no caso de Rohmer, encontramos nos filmes de Rivette algumas preocupações desenvolvidas por ele em seus textos. Sua entrega à mise en scène como identificada em Preminger é clara. Vemos na quase totalidade de seus filmes uma preferência por planos longos, em profundidade, nos quais a câmera persegue os personagens enquanto delineia o espaço ao redor deles, compreendendo as distâncias e ampliando-as constantemente. Já em A Religiosa (La religieuse, 1966), por exemplo, vemos uma postura que Rivette desenvolve em outros filmes e que retoma de modo mais incisivo em Não Toque no Machado (Ne touchez pas la hache, 2007): uma fluidez no interior de cada cena, aliada a um intervalo um tanto seco entre um plano e outro, criando ao mesmo tempo uma lacuna e uma dobra nas extremidades das cenas. $A$ Religiosa deixa claro que há uma compreensão de que o que é visto é filtrado pelo teatro, por operações cênicas moduladas pelas exigências técnicas do cinema: a câmera coordena as entradas e saídas dos personagens pelas laterais, seus deslocamentos em profundidade; a continuidade, quando se mantém, serve para delinear um movimento, observar o espaço por outro ângulo, reordenar as relações entre os personagens, as posições e escalas deles no quadro. Soma-se a isso o uso do som direto, especialmente em Não Toque no Machado, em que cada gesto de Armand (Guillaume Depardieu) parece ressoar em todo o cenário. A câmera de Rivette registra suas hesitações num evento que é o resultado de uma coreografia, mas no qual nenhum movimento parece executado mecanicamente. O personagem de Depardieu, um herói de guerra que manca de uma perna e às vezes utiliza uma bengala, é uma fonte inesgotável de ruídos; suas diversas mudanças de postura enquanto caminha - às vezes calma, às vezes violentamente - pelos corredores com pisos de madeira são a própria expressão rítmica do momento, de uma integração completa entre suas intenções e suas ações. A

\footnotetext{
185 Aumont, O Cinema e a Encenação, op. cit., p. 87.
} 
preocupação visual se estende ao som, e talvez possamos falar aqui, ainda mais do que em Rohmer, do rascunho para uma "ontologia do som cinematográfico".

$\mathrm{Na}$ apresentação de uma entrevista, Jonathan Rosenbaum comenta que "cada filme de Rivette tem seu lado Eisenstein/Lang/Hitchcock - um impulso para desenhar e traçar, dominar e controlar - e seu lado Renoir/Hawks/Rossellini: um impulso de "deixar as coisas irem", de se abrir ao jogo e ao poder de outras personalidades, e observar o que acontece”. Na mesma entrevista, Rivette comenta que Out 1 (1971) começou com um mapa geral da estrutura dramática que dispunha as cenas e os personagens, mas que dentro disso havia um espaço considerável para improvisação, que terminou por alterar a própria construção do filme. ${ }^{186} \mathrm{O}$ mesmo é comentado por Jacques Aumont sobre L'amour fou (1970): "partes inteiras do filme, como o episódio do cão recolhido por Claire ou a destruição do apartamento, são improvisações, e, por várias vezes neste filme, sentimos claramente que o diálogo se deve ao ator, que ele inventa no próprio momento". 187

Por esses motivos a encenação é um tópico tão recorrente na obra de Rivette. Nos dois filmes citados o teatro é incluído como um elemento temático, com a câmera testemunhando cada reação, cada variação dentro das fronteiras espaciais e temporais. Out 1 se inicia com o ensaio de um grupo teatral, e a câmera passeia num plano longo pelo cenário enquanto os personagens fazem uma série de exercícios. L'amour fou possui cenas semelhantes, e grande parte de sua duração é focada nos ensaios e diálogos sobre a encenação de uma peça. Em outros filmes, como Duelle e Noroît (ambos de 1976), encontramos uma investigação dessas tensões em momentos mais específicos, que parecem dilatar completamente o movimento da trama: cenas de apresentação musical ou duelos de espada, caminhadas e trocas de olhares que se estendem por vários minutos, em que a câmera parece mais interessada na apreensão espacial, na coreografia em seu sentido puro, no registro do momento, sendo apenas brevemente pontuada por diálogos ou cortes que avançam a narrativa pela mudança de pontos de vista ou pela

\footnotetext{
${ }^{186}$ Cf. Rosenbaum, "Phantom Interviewers over Rivette", in Film Comment, vol. 10, no 5, set/out, 1974, pp. 18-24. Disponível em: http://www.dvdbeaver.com/rivette/ok/phantomint.html. Acesso em julho de 2014. Rivette é o introdutor de algumas preocupações modernistas no universo dos Cahiers, durante seu período como editor. Seu interesse nessa oscilação da mise en scène parece análoga a duas direções no modernismo musical, representadas por John Cage (em sua busca pela manifestação do acaso) e Pierre Boulez (em sua busca pelo controle cada vez mais estrito). Rivette entrevistou Boulez em 1964; sobre a questão do controle, Boulez diz ter um interesse particular por Outubro (Oktyabr, 1928), de Eisenstein, por sua precisão e "jogo de durações". Ver "Entretien avec Pierre Boulez", in Cahiers du Cinéma, $\mathrm{n}^{\circ}$ 152, fevereiro de 1964, p. 27.

187 Aumont, O Cinema e a Encenação, op. cit, pp. 271-272.
} 
revelação de alguma informação. A relação entre o pintor (Michel Piccoli) e a modelo (Emmanuelle Béart) em A Bela Intrigante (La belle noiseuse, 1996) é também a história dessa tensão, nos sucessivos ensaios e esboços, nas tentativas de encontrar a posição do corpo sob a luz, de dobrar a matéria resistente, de fazer com que a tinta e o traço se completem sobre a tela.

Colin MacCabe, biógrafo de Godard, propõe que o cinema de Rohmer e o de Rivette sejam vistos como desenvolvimentos do axioma de Bazin; mas enquanto Rohmer se volta à Geometria, Rivette se volta à Álgebra. ${ }^{188}$ A presença dos corpos no espaço, as angulações formadas por seus olhares e movimentos, e as qualidades que resultam dessas disposições - esses são elementos geométricos, importantes tanto para Rohmer como para Rivette. Mas em Rivette parece haver uma maior abstração de sentido, o que encontramos principalmente em seus filmes baseados em tramas de mistério ou conspiração. O labirinto narrativo de Out 1 é apenas um dos exemplos, talvez o mais extremo, pelo número elevado de personagens e pela duração. Mas já em seu primeiro longa-metragem, Paris Nos Pertence (Paris nous appartient, 1961), Rivette explora a presença da conspiração como uma rede de sentidos possíveis. A atenção que em Rohmer é reservada aos personagens em sua totalidade (da qual os diálogos expressam uma parcela considerável), em Rivette parece voltar-se ao jogo entre valor e variável, entre o corpo presente na cena e o papel interpretado na trama. Da mesma forma, os movimentos e enquadramentos em Rohmer parecem mais dependentes de sua abordagem romanesca; em Rivette, ao contrário, há alguma independência do olhar e da câmera (um interesse pelo que ele identificou em Lang como sendo a "pura referência espaço-temporal"), ainda que sutil, como um traçado mais visível. Talvez neste ponto possamos levar adiante a metáfora de MacCabe: em Rivette, a Geometria seria entrevista pela Álgebra através de um sistema próprio de coordenadas, no qual a narrativa é uma descrição de algumas funções.

\section{O problema da expressão}

No artigo célebre em que cunha a expressão "câmera-caneta", no final dos anos 40, Alexandre Astruc defende que o cinema caminha na direção das outras artes, no sentido

${ }^{188}$ Cf. MacCabe, Godard: A Portrait of the Artist at Seventy (Londres: Bloomsbury, 2003), pp. 62-63. 
de que "irá se desfazer pouco a pouco desta tirania do visual, da imagem pela imagem, da narrativa imediata, do concreto, para se tornar um meio de expressão tão flexível e sutil como o da linguagem escrita". Numa primeira leitura, a visão de Astruc é extremamente próxima da de Frampton, em seu projeto do cinema como uma contraparte da linguagem. O que parece importar para ele nessa caminhada é a diminuição da presença ontológica dos objetos, de sua imposição espacial pura - em outras palavras, do que constituía a veracidade e força do cinema para Bazin, Rohmer e Rivette. Astruc parece se aproximar ainda mais de Frampton ao dizer que o problema fundamental do cinema é "a expressão do pensamento". ${ }^{189}$

Mas ao descrever o núcleo do que seria essa "linguagem" do cinema, ele revela sua filiação ao realismo de outra forma:

Todo filme, por ser um filme em movimento, ou seja, que se desenrola no tempo, é um teorema [...]. Essa ideias, essas significações, que o cinema mudo tentou criar através de associações simbólicas, compreendemos que elas existem na imagem mesma, no desenrolar do filme, em cada gesto dos personagens, em suas palavras, nos movimentos de câmera que ligam os objetos e os personagens a estes. Todo pensamento, como todo sentimento, é uma relação entre um ser humano e um outro ser humano ou certos objetos que fazem parte do seu universo. É explicitando essas relações, desenhando as tangentes, que o cinema pode ser verdadeiramente o lugar de expressão de um pensamento. ${ }^{190}$

A mise en scène é para Astruc, como para Rivette, sinônimo da composição do filme. O que parecia na superfície uma negação dos aspectos realistas termina por ser novamente a submissão destes a um desígnio, uma intenção que conduz a matéria concreta da realidade visível, em continuidade (ou seja, unificada no espaço e no tempo), ao seu objetivo. A mise en scène, ele continua, "não é mais um meio de ilustrar ou apresentar uma cena, mas uma verdadeira escritura". O caráter de linguagem do cinema, o que possibilita a expressão individual de um cineasta, não se encontra na articulação através da montagem, como pensada por Eisenstein, ou da abstração da própria imagem, mas no olhar que submete o real a um princípio, a uma ideia. Dessa

\footnotetext{
189 Astruc, "Naissance d'une nouvelle avant-garde: la caméra-stylo", in L'écran français, no 144 , março de 1948. Disponível em: http://www.focorevistadecinema.com.br/FOCO4/stylo.htm. Acesso em julho de 2014. Tradução de Matheus Cartaxo.

${ }^{190}$ Ibid.
} 
forma, há ainda uma ligação com a postura realista de Bazin. A mise en scène, afinal, é vista como um olhar ativo e incisivo sobre o mundo, sobre o todo utilizado na construção do filme, a narrativa, seus elementos constituintes, o cenário, os objetos, os personagens em suas relações com a câmera - estática ou em movimento. ${ }^{191} \mathrm{O}$ princípio realista, a aceitação de uma unidade a priori, permanece: é a esta unidade que o compositor deve se reportar, pois sua matéria é inextricavelmente ligada a ela. Suas ideias, sejam elas quais forem, surgem em relação a essa unidade. A mise en scène para Astruc é "a organização das trevas à luz de uma idéia fixa". ${ }^{192}$

O ponto divergente é, portanto, a noção de que deve haver uma ideia por trás da encenação, um fator controlador, que guie o sentido e o movimento interno da realidade representada. O que em Rivette era apenas um dos pólos da composição, em Astruc parece ser o principal. Ele exemplifica, ao falar de Murnau, que cada escolha por parte do cineasta expressa um aspecto, e que é a coordenação destes que forma a ideia geral da cena. Ele se refere à "história do plano" - o resultado de sua direção, ângulo, densidade, tonalidade e ritmo próprios, seguindo um princípio comum. $\mathrm{O}$ desenvolvimento desses fatores "não será em definitivo nada além da realização no tempo de uma fatalidade plástica original em que tudo que deverá se desenlaçar nesses poucos segundos é dado de uma vez por todas". 193

Há neste ponto uma proximidade entre a proposta de Astruc e algumas das ideias de Eisenstein. Ao se perguntar qual seria o método para retratar os eventos no cinema de modo que eles não sejam apenas registrados e reapresentados, mas para que uma atitude em relação a eles também seja proposta, Eisenstein diz que uma possibilidade é que o objeto e a atitude coincidam - ele exemplifica com o que seria um correspondente verbal: "a alegre alegria”. "Em outras palavras, o herói se entristece e, em uníssono, a natureza se entristece, e a iluminação, algumas vezes a composição do plano e (mais raramente) o ritmo da montagem - porém mais frequentemente apenas acrescentamos música". ${ }^{194}$ Outras possibilidades envolvem os diferentes tipos de contraste e conflito

\footnotetext{
${ }^{191}$ Astruc, "Da Imagem à Ideia”. Disponível em: http://www.focorevistadecinema.com.br/FOCO4/imagemideia.htm. Acesso em julho de 2014. Tradução de Bruno Andrade.

${ }^{193}$ Astruc, "Le feut et la glace", in Cahiers du Cinéma, no 18, dezembro de 1952. Disponível em: http://www.focorevistadecinema.com.br/FOCO4/feu.htm. Acesso em julho de 2014. Tradução de Bruno Andrade.

${ }^{194}$ Eisenstein, "Sobre a estrutura das coisas", in A Forma do Filme (Rio de Janeiro: Jorge Zahar, 2002), p. 142.
} 
entre o objeto e a atitude. Dessa forma a composição pode se apoderar dos fenômenos para representar, através deles, uma única lei estrutural. Astruc parece indicar algo semelhante, ainda que por outra via, sem privilegiar a montagem e o choque entre diferentes imagens.

Jacques Aumont comenta que a "escrita cinematográfica" para Astruc seria talvez algo próximo dos ensaios filmados de Chris Marker e Jean-Luc Godard, isto é, mais dependente dos procedimentos de montagem e da resolução da "ambiguidade intrínseca da imagem". O cinema de Astruc, para Aumont, não seria um exemplo desse direcionamento - que ele vê em uma obra como História(s) do Cinema (Histoire(s) du Cinéma, Godard, 1988-98). Mas em outro momento Aumont diz que talvez o cinema de Robert Bresson seja um exemplo mais adequado à aspiração de Astruc. ${ }^{195}$ Bresson desconfia da imagem que é simplesmente bela, ou expressiva; ele chega a estender essa desconfiança ao texto, à atuação, à montagem, à composição como um todo. Se há um ideal para Bresson, é a neutralidade das partes, em que cada uma delas só possui função, sentido e força dentro da organização elaborada pelo cineasta. Em outras palavras, um cinema que não represente ou expresse, mas que figure um pensamento.

Os textos e filmes de Astruc tornam a questão mais complexa, e se sua postura pode ser resumida, talvez ela se aproxime mais do segundo ponto proposto por Aumont, ou seja, mais da postura de Bresson do que de Marker ou Godard. Mas Astruc não é contrário à "expressividade"; ele defende, num texto altamente elogioso, que é em Murnau que "o expressionismo alemão terá encontrado o seu florescimento". A arte de Murnau é descrita como sendo baseada na transfiguração do real, uma "orquestração lírica e apaixonada de um visual exacerbado por um senso plástico impressionante, em que a plástica no entanto se recusa incessantemente a ser recebida como tal". ${ }^{196} \mathrm{O}$ drama da luz e da sombra em Fausto (Faust, 1926) é um dos exemplos mais evidentes do que Astruc reconhece: aqui a plasticidade se torna a concretização dos temas pelas figuras desenhadas e esculpidas pela iluminação, pela própria densidade da luz entrevista pela fumaça ou difusa por outras superfícies, pelo jogo de efeitos que move e reconfigura os personagens e os cenários (as maquetes, as aparições de Mefistófeles). Em A Última Gargalhada (Der letzte Mann, 1924), Murnau abdica dos intertítulos e constrói toda a narrativa a partir da perspectiva do protagonista, com a câmera se

\footnotetext{
195 Cf. Aumont, O Cinema e a Encenação, op. cit., pp. 68-70.

${ }^{196}$ Astruc, "Le feut et la glace", in Cahiers du Cinéma $\mathrm{n}^{\circ}$ 18, p. 11.
} 
movimentando e alterando o campo de visão (também com efeitos, filtros e distorções) para traduzir diretamente seu estado psicológico. ${ }^{197} \mathrm{Em}$ ambos os casos, há um controle óbvio do cineasta sobre esses aspectos, o que reforça o ponto sobre a concretização da ideia através dos elementos cênicos. O importante é que essa plasticidade esteja na realidade, e não apenas no aparato fílmico.

Astruc comenta como em O Poço e o Pêndulo (Le Puits et le Pendule, 1964) ele se deparou com questões ligadas à aplicação prática dessa concepção, na adaptação literária do conto de Edgar Allan Poe. O texto original, ele diz, trata da "narrativa de um pesadelo", "da primeira à última linha um raciocínio ou uma sequência de raciocínios de uma lógica perturbada". Uma progressão mental, portanto; a exploração dos meandros de um movimento interno, psicológico, e que, seguindo a ocasião proposta por Poe, ocorre com um homem aprisionado numa cela, acorrentado, à espera de uma lâmina que balança pendurada sobre o teto e que dele se aproxima lentamente. O filme de Astruc é quase sinônimo da descrição dos espaços em que ocorre a ação, começando com os corredores que levam à cela enquanto ouvimos a narração e finalmente chegando ao prisioneiro, cercado por elementos que a câmera logo se põe a mostrar, "ligados uns aos outros, passando de uns aos outros, Poço, Pêndulo, um prato cheio de uma refeição gordurosa, ratos, correntes, isto quer dizer os objetos e seres mais concretos, mais reais, as súplicas, dispostas aqui numa ordem rigorosa para servir de limite a um pensamento que nunca cessa de funcionar". ${ }^{198}$ No sistema fechado da cela, esses elementos têm poucas relações possíveis, e o andamento geral da ação é medido pela descida do pêndulo. O prisioneiro lamenta, estremece, considera seus entornos, até que os ratos roem as cordas e o libertam a tempo de fugir do corte fatal. Mas em seguida, outro problema se coloca, pois as paredes começam a se mover, ameaçando a constrição completa do espaço da cela, o que logo se revela tendo outra medida: a presença de um poço, para o qual o personagem aos poucos é empurrado.

Nesse contexto, não resta outra alternativa para Astruc senão o respeito pela fisicalidade do espaço, pois é através da altura, largura e comprimento da cela que o drama do personagem se realiza. Bazin se referia aos "fatos puros e insignificantes" de

\footnotetext{
${ }^{197}$ Também aqui Astruc parece se aproximar do Eisenstein de "Palavra e imagem", in $O$ Sentido do Filme (Rio de Janeiro: Jorge Zahar, 2002), pp. 13-19. Eisenstein diz que o objetivo do cinema deve ser "a exposição coerente e orgânica do tema, do material, da trama, da ação, do movimento interno da sequência cinematográfica e de sua ação dramática como um todo". A própria seleção das imagens deve considerar os aspectos do tema a serem justapostos para que suscitem no espectador a "imagem do tema". Ver também "Forma e conteúdo: prática", p. 106.

198 Astruc, "Da Imagem à Ideia".
} 
Rossellini; Astruc parece diminuir consideravelmente essa "insignificância" por sua insistência na geometria da cena, na interdependência dos objetos, ainda que não efetue uma análise como a de Griffith. Se a história do plano é a realização no tempo "de uma fatalidade plástica original", a história da cena é a decorrência da ordem dos planos, e a do filme a decorrência da ordem das cenas - uma lógica que inclui a plasticidade do cenário e dos próprios planos. $\mathrm{O}$ vocabulário e as referências de Astruc remetem às notas de Paul Valéry sobre o funcionamento da tragédia clássica:

\begin{abstract}
A tragédia clássica, um experimento laboratorial em uma sala fechada Pessoas, coisas e eventos, reduzidos ao que é necessário para os propósitos do argumento em questão. Eles não possuem existência fora da cena, fora daquela trama particular. Eles são simplesmente partes de uma única cadeia de circunstâncias. Eliminação do acaso - ou de acontecimentos casuais. Em tudo 'clássico', leis naturais (que não possuem um rosto humano) são postas de lado - e o caos das coisas, seu desdobramento e sobreposição, é negado. A realidade é substituída pelas regras da arte, que são finitas, calculadas; e por seres racionais. ${ }^{199}$
\end{abstract}

A preferência de Astruc por construções claramente ordenadas e sua tendência a estruturar as narrativas nos moldes clássicos remetem ao elogio de Rivette sobre o controle de Lang, com o diferencial que Astruc não parece realizar a mesma "negação" dos elementos, e sim o potencial de certa forma catártico desse controle, direcionado aos seus limites.

Em Évariste Galois (1965), Astruc mostra a última noite do famoso matemático, morto num duelo ainda jovem. Vemos a obsessão de Galois com o manuscrito que deixará para a posteridade, em que elabora sua teoria dos grupos, enquanto amigos tentam persuadi-lo a se preparar para o duelo iminente. ${ }^{200}$ Acompanhamos o protagonista no que parece ser um estábulo, onde pratica muito brevemente o tiro ao alvo. A câmera acompanha Galois em suas caminhadas de um lado para o outro enquanto é repreendido por outros personagens - a angulação sendo alterada apenas para enviar nosso olhar ao ponto ao qual ele se direciona. O mesmo princípio é repetido

\footnotetext{
${ }^{199}$ Valéry, in Stimpson, Op. cit., p. 257.

${ }^{200}$ Frampton se refere à teoria dos grupos de Galois como "a metahistória da matemática", uma disciplina que descreveria as relações possíveis dentro da matemática. Ver "For a Metahistory of Film", in Jenkins, Op. cit., p. 133.
} 
no duelo. Acompanhamos Galois pela floresta, em movimentos retilíneos, até o espaço em que os assistentes o esperam, uma clareira ampla sob um céu límpido. Tem início então a coreografia que precede o duelo propriamente dito, na caminhada dos assistentes para marcar os pontos em que cada um dos participantes deverá se colocar. A câmera os acompanha, traçando no solo o perímetro que é ao mesmo tempo a razão social do evento e o princípio de composição, a coordenação formal que Astruc projeta sobre a cena. O resultado é esperado, a morte de Galois já estabelecida como um fato; resta a demonstração do teorema que é sinônimo da "ideia" do filme, a ênfase em algumas de suas qualidades, a percepção do drama do personagem que ecoa na música, na fuga dos outros participantes ao som da polícia e no movimento final da câmera, que mostra o matemático caído na estrada.

\section{O acordo entre o gesto e o espaço}

Michel Mourlet, assim como Bazin, entende que as outras artes trabalham a partir da semelhança com a realidade, enquanto o cinema trabalha a partir de sua objetividade fotográfica. Em seu manifesto publicado nos Cahiers du Cinéma em 1959, ele apresenta seu ponto de partida:

A arte sempre havia sido uma mise en scène do mundo, ou seja, uma chance dada à realidade contingente e inacabada de se locupletar, de um golpe preciso, segundo os desejos do homem. Mas esse mundo não podia ser apreendido senão por um meio termo, era preciso recriá-lo em uma matéria indireta, transpô-lo, proceder por alusões e convenções, na impossibilidade de uma possessão imediata. [...] Ora, no fim do século XIX, um evento considerável vem bagunçar esses dados. $\mathrm{O}$ meio de captar a realidade diretamente, sem mediação, sem essas convenções cuja necessidade Valéry tinha compreendido muito bem quando se trata de recriar pelas forças do homem, fora descoberto. Um olho de vidro e uma memória de bromato de prata deram ao artista a possibilidade de recriar o 
mundo a partir daquilo que ele é, portanto de fornecer à beleza as armas mais agudas do verdadeiro. ${ }^{201}$

Em decorrência disso, Mourlet aproxima-se de Bazin ao tratar de alguns tópicos. Ele condena, por exemplo, o "caligarismo", por deformar a realidade sensível, alterando seus aspectos plásticos, e a sintaxe da montagem, por dispersar e reorganizar essa realidade, quebrando sua continuidade. Em ambos os casos, o sentido interno seria deslocado e alterado através de metáforas, ou seja, de uma lógica própria das outras artes, mas não do cinema. As críticas de Bazin são em geral menos incisivas; ele concorda nos dois pontos, mas aceita a presença da montagem em níveis consideráveis. A negação de Mourlet, como veremos, é mais categórica.

Além disso, Mourlet considera que o som é uma implicação necessária das premissas visuais do cinema - um eco às aspirações do cinema total. $\mathrm{O}$ cinema mudo necessitava do som, apenas não o havia alcançado como tecnologia integrada. Isso não significa que ele condene qualquer cineasta do período; Griffith e Stroheim são vistos sob uma luz positiva, como nomes que entrecortavam as cenas com intertítulos não para trair a continuidade, mas porque lhe faltava exatamente a palavra falada.

Mas a transparência do ideal de Bazin, de um cinema que permite à realidade sua própria revelação, sofre uma diminuição com a formulação de Mourlet de que esse processo ocorre de acordo com os "desejos do homem". Esta parece ser a marca definitiva de uma separação entre os dois autores.

A arte se insere numa falha. Toda atividade é produto de uma falta, o movimento de um desequilíbrio rumo ao equilíbrio. O fazer é um deslizamento ontológico rumo à satisfação móvel. Produzir arte significa construir com o já existente um existente novo que de alguma forma exorciza o artista. [...] Recriar um mundo que ao mesmo tempo exorciza o artista e gratifica o espectador, por uma coincidência da vontade do primeiro com o desejo de ordem do segundo no seio de assombrações comuns, reconciliar, tal parece o fim da arte enquanto ato destinado por sua essência de ato a preencher o vazio. ${ }^{202}$

\footnotetext{
${ }^{201}$ Mourlet, "Sur un art ignoré", in Cahiers du Cinéma, no 98, agosto de 1959, p. 24. Disponível em: http://arqueologiadocinema.blogspot.com.br/2009/05/sobre-uma-arte-ignorada_18.html. Acesso em julho de 2014. Traduzido por Luiz Carlos Oliveira Jr.

202 Ibid., p. 28.
} 
Ele não concebe, portanto, a realidade como a unidade cuja ambiguidade é uma qualidade, mas como algo que só pode possuir valor numa representação através da intervenção do homem - como vimos na primeira citação, essa realidade é considerada "inacabada". Há uma preferência pelo que ele chama de "construir com o já existente", e mesmo pela noção de "exorcizar o artista", mas o que ele busca é uma dinâmica entre o artista e o real, uma reconciliação, um equilíbrio. Ele defende o cinema como um confronto do homem com a realidade, para que, através da contemplação, a consciência "percorra o círculo completo" e reencontre a si mesma. Por essa razão, Mourlet diverge também de Bazin em relação ao neorrealismo, ao dizer que

\begin{abstract}
se o cinema fosse tomado como uma sensibilidade insensível, um olhar impassível sobre o mundo, esse caráter poderia espessar ainda, se houvesse necessidade, o mal-entendido que quer fazer da arte um reflexo passivo da realidade integral, enquanto precisamente essa atividade é nascida da necessidade de reformá-la, de se reconciliar com ela. Colocar o homem diante da imagem de um mundo que ele espera exorcizar por meio dessa imagem (do contrário, não há necessidade de imagem, o mundo basta) é o projeto contraditório do "realismo". Zavattini representa esse projeto em seu estado de absurdidade explícita, o documentário de uma mediocridade, 90 minutos para nada, pois não valeria a pena alugar uma poltrona do teatro para ver o que a rua nos oferece com o mérito de ser real. ${ }^{203}$
\end{abstract}

A concepção de realidade de Bazin é a da totalidade, uma espécie de perfeição (ainda que ambígua) das coisas, que para existir depende apenas delas mesmas - por isso resta ao homem observá-las. A concepção de Mourlet se refere a uma contingência; o objetivo do homem é atingir a completude se reconciliando com o mundo. $\mathrm{O}$ absoluto, “exógeno no mundo, endógeno na arte", passa a ser fruto da ação de um homem divinizado. $^{204}$

O que Mourlet faz em seguida é uma descrição dos fatores envolvidos na realização de seu projeto. Se o cinema deve confrontar o real, se deve haver um equilíbrio nessa relação, entre "os fossos do realismo e os sonhos dos poetas, entre o documentário e a fantasia", então deve haver técnicas e elementos mais propícios que

\footnotetext{
203 Ibid.

${ }^{204}$ Cf. Antoine Katerji, "Bazin, Mourlet: Convergence et Oppositions”, in Michel Mourlet, L'écran éblouissant (Paris: Presses Universitaires de France, 2011), p. 267.
} 
outros. Não se deve "restituir aparências incontroladas" (Zavattini) ou "autorizar a mentira" (Caligari), mas tratar "a beleza imposta pela evidência do olho irrecusável". Não pela montagem que imprime à sucessão de imagens um ritmo externo, mas por uma coordenação que dissolva a descontinuidade inevitável pela arte da decupagem, o que ele reconhece, como Rivette, na mise en scène, a colocação dos atores e objetos, em seus movimentos no interior do quadro. Para Mourlet, como para Astruc, toda a expressão se encontra na mise en scène. Mas diferente de Astruc, Mourlet não parece ter a "ideia" como força motriz.

A montagem para Bazin é um mal necessário, mas também pode ser a condução do estilo, que dobra a matéria até sua forma necessária, magnetizada pela psicologia da narrativa. Para Mourlet, a presença dos corpos no espaço deve ser insistente, o que exige um controle permanente de seus movimentos e proporções, cuja fragmentação e articulação interferem de maneira destrutiva. Bazin elogia Welles, por exemplo; Mourlet já o considera um exemplar do barroco, com sua galeria de personagens, temas, ângulos e cenas excessivas. O mesmo ocorre com Eisenstein e Hitchcock, cineastas em que "o signo sufoca a significação", em que há um direcionamento presente demais na construção.

Mourlet defende um fundamento básico do classicismo: a transposição da realidade bruta para uma série de elementos “purificados", um filtro que, sobreposto ao mundo, determina seus aspectos passíveis de articulação e revelação. Assim como a escala musical sobrepõe ao espectro sonoro uma gama de sons idealizados e a perspectiva sobrepõe ao espaço visível uma grade geométrica, Mourlet propõe referências para que o cinema atinja a fascinação da consciência pelo mundo, a absorção pelo espetáculo que, segundo ele, ilumina e traz a lucidez. As aparências devem ser selecionadas, pois não se deve observar movimentos dispersos, e sim alguns movimentos "privilegiados". O que importa é a relação entre o homem e o cenário, e para isso a realidade do corpo do ator é fundamental, pois é ela que

veiculará as assombrações e a vontade de sedução, engendrando uma direção de gestos raros, uma arte de epiderme e das entonações de voz, um universo carnal [...]. Não uma demonstração, uma sentença, o suporte sacrificado de uma operação superficial do intelecto, mas a linha melódica, com seus crescendos, 
suas pausas, suas irrupções, movimentos secretos do ser, nos concernindo ao mais vivo de nós mesmos pela via do perigo e da exaltação. ${ }^{205}$

Em outro texto, Mourlet se aproxima novamente de Rivette ao afirmar que a realidade surge "na iluminação da evidência", através de "clarões sucessivos que abrem a vida do conhecimento". Uma apreensão pelo confronto imediato, e não pela demonstração. Mas o papel que Rossellini representava para Rivette (como para Bazin), em Mourlet é representado por Joseph Losey, de quem ele faz afirmações semelhantes às de Rivette - "Losey é o realizador cujo espelho é de uma água tão pura que se faz esquecer e somente a realidade, em seus filmes, se desvela diante de nós"; um realizador que "sabe impor constantemente a presença do mundo, o peso do ambiente sobre o centro da cena, pela utilização dos ruídos, das luzes, pela identificação do cenário ao drama e do drama ao cenário". Uma transparência e objetividade semelhantes, mas com uma diferença crucial: para Mourlet, é o ator, como herói, quem deve determinar as coordenadas do espaço, portanto qualquer mistério deve se referir necessariamente a ele, e não a uma natureza que o transcende (como em Viagem à Itália) ou que o derruba (como em Stromboli). Rossellini é um cineasta-chave para Bazin justamente por representar o homem num mundo que existe além dele; Losey é preferido por Mourlet porque em seus filmes o combate é sempre entre os homens e o espaço físico definido por eles. ${ }^{206}$

A preocupação com a relação entre os atores e o espaço é recorrente no pensamento de Mourlet, e revela sua propensão ao classicismo através de duas noções: a da violência como uma espécie de energia que guia as tensões da cena, e da busca por referências firmes nesse direcionamento.

Se o acordo de um gesto e de um espaço é a solução e a conquista de todo problema e de todo desejo, a mise en scène será uma tensão rumo a esse acordo, ou sua imediata expressão. A arte é uma conquista de si mesmo, primeiramente, e do mundo, se possível; daí três condições necessárias: um método rigoroso, um orgulho sem o qual nada de vasto é concebido ou sequer tentado e um

\footnotetext{
205 Ibid.

206 Mourlet, "Beauté de la connaissance", in Cahiers du Cinéma, no 111, setembro de 1960, p. 35. Disponível em: http://www.contracampo.com.br/92/artloseymourlet1.htm. Acesso em julho de 2014. Traduzido por Luiz Carlos Oliveira Jr.
} 
grande respeito pelo verdadeiro. Que uma dessas três condições apresente falha, a obra carecerá do equilíbrio indispensável à sua função e sua eficácia. ${ }^{207}$

A matéria da mise en scène, o bloco de realidade que resulta das aparências selecionadas, deve ser mostrado como uma cadeia de eventos indispensáveis, de maneira direta, construindo "uma arquitetura cuja beleza global nasce da exatidão do papel atribuído às suas partes". Mourlet se refere ao orgulho da busca pela verdade e da humildade necessária para encontrá-la; da busca por uma transparência que seja "porosa aos fenômenos", que se entregue ao mundo ao mesmo tempo em que o absorva. É apenas com essa postura que a dinâmica interna dos eventos seria revelada, que o espaço seria potencializado. O que ele chama de "sabedoria do classicismo" é precisamente o uso de certo rigor, de referências fixas como aberturas para a expressividade - o que nos remete às preferências de Rohmer, com a diferença óbvia sendo a insistência de Mourlet num método mais rigoroso.

Permanecer ligado ao centro. Esta é uma afirmação importante, se considerarmos que diz respeito, primeiramente, ao centro espacial do quadro, e ao centro dramático da cena. A importância dada ao ator, especialmente ao protagonista como centro psicológico da narrativa, faz com que o sistema de Mourlet se revele a contraparte antropocêntrica do sistema de Bazin.

A violência é para Mourlet a energia que move a mise en scène. Se o cinema é o confronto entre o homem e o mundo, e se a tensão entre os dois termos depende do que ocorre no espaço representado, pelas distâncias, valores e choques, então deve ser possível reconhecer os diferentes resultados e efeitos que surgem desses fenômenos. Ele a define da seguinte maneira:

Violência é descompressão: emergindo da tensão entre o indivíduo e o mundo, ela explode quando a tensão atinge seu ponto máximo, como um abcesso explodindo. Ela precisa ser atravessada antes que possa haver qualquer repouso. É o que me possibilita dizer que cada obra de arte contém violência, ou pelo menos a postula, se é que arte é uma maneira de atenuar a violência através do

\footnotetext{
${ }^{207}$ Mourlet, "Une lucidité virile", in Présence du Cinéma, no 13, maio de 1962, p. 3. Disponível em: http://arqueologiadocinema.blogspot.com.br/2009/05/marca-da-maldade-1958-orson-welles.html. Acesso em julho de 2014. Traduzido por Luiz Carlos Oliveira Jr.
} 
reconhecimento dos termos do conflito, e o poder que este conhecimento confere para resolvê-lo. ${ }^{208}$

Mourlet prossegue dizendo que o cinema é uma arte com maior potencial para a violência, ou que possui mais sintonia com ela, pois se a violência emerge do homem, a câmera pode capturá-la sem a necessidade de descrever sua progressão. Essa progressão é revelada naturalmente, gradualmente, pela manifestação dos aspectos interiores dos corpos em suas superfícies - numa afirmação idêntica à de Rivette sobre Hawks e que se assemelha mesmo ao que Bazin elogia em Renoir, mas redirecionada para o conflito físico. O herói é elogiado por Mourlet como o introdutor, na ordem do mundo, de uma desordem pessoal. A busca pela harmonia, da consciência do espectador em relação ao mundo representado no espetáculo, se reflete na busca do herói pelo equilíbrio no interior da própria representação - ambos buscam completar o intervalo entre o homem e a realidade. A violência é a energia a ser reconhecida e medida; o herói é o núcleo ao redor do qual os elementos ora se aproximam, ora se distanciam, ora interagem diretamente.

A partir disso, Mourlet estabelece uma verdadeira escala moral de representações da violência, observando os "resultados" em alguns cineastas, e ordenando-os do mais baixo até o mais elevado. A parcela negativa da escala é exemplificada por Elia Kazan ("um frenético show bêbado de marionetes, cuja expressão mais consumada é o desprezível Karl Malden"), Orson Welles ("restringida, mesquinhamente bloqueada, sem maiores reverberações além da comoção barulhenta que gosta de produzir"), Luis Buñuel (“cada expressão, cada impulso apaixonado esteve ao serviço de ideias que desde a adolescência não somos capazes de nos livrar") e Nicholas Ray ("uma violência mais substancial, mais sensual, mais real, mas infelizmente desenfreada"). A parte positiva da escala é representada por Raoul Walsh (“a violência da guerra ou do conquistador solitário, e o que ele expressa é a coragem de viver, uma consciência da luta do homem contra os elementos, homem contra homem, e do desencadeamento do desejo de vitória”), Fritz Lang (“coagida, impedida, explícita e latente em cada ação e cada olhar, e de forma alguma diluída pela fraqueza como em Ray, na realidade é como um tigre prestes a dar o bote"), e finalmente Joseph Losey ("a

\footnotetext{
${ }^{208}$ Mourlet, "Apologie de la violence", in Cahiers du Cinéma, no 107, maio de 1960, p. 24. Disponível em: http://fichat.wordpress.com/2010/04/26/apologia-da-violencia-de-michel-mourlet/. Acesso em julho de 2014.
} 
violência em Losey encontra-se sob a pele, capturando aquele momento em que o pulso se acelera freneticamente assim que, com cada batida do coração, o homem se flexiona para enfrentar o que vem em sua direção"). ${ }^{209}$

Na preferência por aqueles que organizam a realidade imperfeita, dão forma ao que é disforme, transformam o caos em ordem, Mourlet faz o elogio dos filmes de gênero, os filmes de ação, em que a violência aparece mais diretamente, e o filme de guerra, em que as condições são mais especialmente propícias para que o conflito brote a qualquer momento - é por essa ótica que Walsh é visto positivamente. Em Lang, Mourlet parece admirar as características descritas por Rivette, o controle exercido sobre o mundo que termina por neutralizar a representação, a cena, a interpretação, ao ponto em que resta apenas uma progressão atraída pelo vácuo da causalidade: “A eliminação do acaso e a dominação constante das formas, por uma arquitetura na qual todas as partes se comuniquem e se provoquem, resultarão em uma fascinação, ou na impossibilidade do espectador se desconectar da ordem do espetáculo". ${ }^{210}$

É no díptico indiano - O Tigre de Bengala (Der Tiger von Eschnapur) e $O$ Sepulcro Indiano (Das indische Grabmal), ambos de 1959 - que Mourlet reconhece o ápice da arte de Lang. ${ }^{211}$ Aumont comenta algumas das características do filme que parecem atrair o interesse de Mourlet, por sua adequação a um temperamento classicista:

O filme apresenta soluções límpidas, que privilegiam o centro da imagem e, frequentemente, a simetria [...]. Os travellings são muito raros, sempre de pequena amplitude, nunca demonstrativos nem insistentes, e puramente funcionais (um reenquadramento para seguir uma personagem que sai, por exemplo). Os espaços são vastos, e o filme acentua a sensação de vazio que daí resulta através do uso frequente de uma focal muito curta, deixando desenrolarem-se até o fim as deslocações das personagens em profundidade. A representação dos atores - certamente a mais desconcertante de todas as escolhas de Lang - é perfeitamente coerente com estes princípios: à exceção de

\footnotetext{
209 Ibid., pp. 25-27.

${ }^{210}$ Mourlet, “Trajectoire de Fritz Lang”, in Cahiers du Cinéma, no 99, setembro de 1959, p. 21.

211 Considerando as premissas de Mourlet, é uma decorrência lógica que ele prefira a fase final de Lang em detrimento do período mudo, em que não apenas faltava o som, como havia um maior interesse na construção de um universo muitas vezes fantástico - como nas duas partes de Os Nibelungos (Die Nibelungen, 1924), em Metropolis (1927), ou A Mulher na Lua (Frau im Mond, 1929). A entrega de Lang à realidade social americana e ao trabalho com os gêneros evidencia a autonomia da mise en scène como entendida por Mourlet.
} 
algumas cenas de ação (e até nestas), os corpos são assimilados a estátuas, com uma presença tanto mais cativante quanto a sua imobilidade é animada por um jogo extraordinariamente intenso dos olhares. ${ }^{212}$

Losey, como já foi dito, é uma espécie de ideal para Mourlet, a violência que se inicia sob a superfície, mas que se reflete nela, que a anima, que se revela o próprio motor dos movimentos, e então da trama, da busca e reconhecimento do homem em seu lugar no espaço. ${ }^{213}$ Losey parece associar as qualidades clássicas e românticas preferidas por Mourlet; as qualidades lógicas da ficção, o encadeamento causal e a clareza da construção, e as qualidades passionais, uma vivência intensa, uma plenitude na contemplação dos conflitos. Diferente de Eisenstein ou Hitchcock, Mourlet vê em Losey um cineasta que não se projeta sobre o mundo, não submete a realidade a um olhar que se propõe inteligente ou imaginativo, que não impõe um "estilo", mas uma contemplação serena, um olhar límpido sobre as paixões mesmo quando estas se debatem, ou ainda, principalmente nestas ocasiões.

As mesmas características indicadas por Aumont em Lang são apontadas por Luiz Carlos Oliveira Jr. em uma cena de The Criminal (1960), de Losey. John Bannion (Stanley Baker) entra na sala do apartamento trazendo no colo sua namorada, enquanto um homem afina o piano no mesmo cômodo; a campainha soa, ao qual Bannion joga a namorada no sofá e vai até a porta. A concisão rítmica, a exatidão dos enquadramentos, a disposição precisa dos personagens de modo que cada movimento da câmera descreve uma trajetória específica, e principalmente o caráter privilegiado dos personagens em relação ao cenário, são algumas das qualidades que indicam o classicismo como entendido por Mourlet. ${ }^{214}$ Na cena inicial de The Big Night (1951) vemos como isso é eventualmente tingido pela intensidade mais própria de um temperamento romântico, na erupção da violência dentro de uma ocasião medida e controlada. A cena se passa num bar, em que Andy (Preston Foster) deve se manter à parte enquanto seu pai (John Drew Barrymore) é humilhado em seu próprio estabelecimento por um jornalista (Howard St. John). Todo o conflito é concentrado em dois planos: o jornalista, em close, olha para o pai de Andy; em plano médio, o pai de Andy retorna o olhar, enquanto Andy olha para

2 Aumont, O Cinema e a Encenação, op. cit., pp. 93-95.

213 Ibid., pp. 25-27.

${ }^{214}$ Cf. Luiz Carlos de Oliveira Jr., A mise en scène no cinema: Do clássico ao cinema de fluxo (São Paulo: Papirus, 2013), p. 202. 
o pai e o balconista olha para Andy, atento às suas flutuações emocionais para restringílo caso tente interferir. Quando o pai de Andy se ajoelha e é golpeado pelo jornalista, a tensão finalmente explode, e a câmera se aproxima rapidamente de Andy, que abaixa a cabeça no balcão e tem ela coberta pela mão do balconista. Assim como Bazin, há uma preferência pelo cineasta como aquele que potencializa a realidade, mas Mourlet parece exigir uma potencialização mais específica, mais tensionada. 


\section{O cinema de vanguarda e a mímese da consciência}

A relação de Frampton com os outros autores e cineastas aqui considerados é diferente daquela descrita sobre Bazin e os críticos dos Cahiers du Cinéma. Frampton não tinha a crítica como sua atividade principal, apesar de escrever com regularidade. Também não foi ligado exclusivamente a uma única publicação, tendo colaborado com revistas como Film Culture, Millennium Film Journal, Artforum e October. Sua carreira compreendia, além de seus filmes, palestras e aulas, tendo passado anos como professor na State University of New York. Essa trajetória se deu de maneira semelhante para outros cineastas experimentais do período, e dessa forma o ponto de cruzamento entre os autores deste capítulo é tanto um centro de exibição, estudo, discussão e preservação de filmes, com foco no cinema de vanguarda - o Anthology Film Archives, fundado em 1969 por Jonas Mekas, Jerome Hill, P. Adams Sitney, Peter Kubelka e Stan Brakhage como uma revista - a Film Culture, criada por Mekas, que também deu preferência a este cinema e serviu de veículo para declarações, ensaios e críticas dos principais diretores do período. Frampton é apenas um dos vários cineastas que passaram pela Film Culture e pelo Anthology, e apesar de sua interação constante nas publicações citadas, e em palestras ou debates registrados e transcritos, sua escolha como ponto de referência na dissertação é menos óbvia que a de Bazin.

Há também outro fator que diferencia essa vertente daquela da seção anterior. Com exceção de P. Adams Sitney, os outros autores a serem analisados aqui (Brakhage, Snow e Kubelka) não partiram de um trabalho crítico para a realização. A vanguarda americana de certa forma ecoa as preocupações das vanguardas dos anos 1920, e compartilha a postura que alia a criação artística com a reflexão teórica num diálogo constante. Assim, grande parte das ideias descritas por esses autores já partem de uma proposta de cinema - de maneira direta, e não indireta como a dos autores dos Cahiers e confrontam suas obras também de maneira mais clara, referindo-se a exemplos específicos e facilitando a descrição das composições. 


\section{A morfologia da vanguarda americana}

P. Adams Sitney é o principal historiador da vanguarda americana, e seu principal livro, em que expõe uma tese sobre o desenvolvimento das diferentes vertentes do cinema experimental nos EUA, é Visionary Film, que em sua primeira edição compreende o período de 1943 ao final dos anos 1970. Um novo prefácio e um novo capítulo foram acrescentados às edições posteriores, mas a intuição fundamental que define a tese permaneceu a mesma.

A concepção dessa tese teve início em uma série de palestras, apresentadas no Museum of Modern Art de Nova York, nos anos 1970, com duas delas sendo transcritas e publicadas na revista Film Culture. ${ }^{215}$ Na palestra "The Idea of Morphology", ela é resumida por Sitney da seguinte maneira:

A grande aspiração da vanguarda americana tem sido a mímese da mente humana em uma estrutura cinematográfica. Começando com a tentativa de traduzir sonhos e outras revelações do inconsciente pessoal nos filmes de transe, através da imitação do ato de ver no filme lírico e do inconsciente coletivo no filme mitopoético, esse cinema tentou definir a consciência e a imaginação. Suas últimas tentativas se aproximaram da forma meditativa (o filme estrutural) para evocar mais diretamente estados de consciência e refletir a imaginação do espectador. $^{216}$

Filme de transe, filme lírico, filme mitopoético, filme estrutural: essa é a terminologia com a qual Sitney tenta dar conta da multiplicidade de obras que surgem no chamado underground americano. O texto é revelador no sentido em que indica a busca de Sitney por um reconhecimento além da mera classificação. O que ele busca é uma morfologia, isto é, o estudo dos caminhos que essas obras tomam no decorrer do tempo, os desdobramentos das influências e temas, e como esses desdobramentos tornam claras algumas relações entre filmes e cineastas. A ordem dos gêneros é importante no entendimento desse processo. Sitney defende que o surgimento deles se dá num arco mais amplo, como num motivo central que move o cinema de vanguarda.

\footnotetext{
${ }^{215}$ Duas das palestras, "The Myth of the Absolute Film" e "The Myth of the Filmmaker" não foram publicadas, mas seu conteúdo, como o das outras duas, foi incorporado em Visionary Film.

${ }^{216}$ Sitney, "The Idea of Morphology", in Film Culture, n' 53-55, primavera de 1972, p. 20.
} 
Esse motivo é próximo da aspiração de Frampton por uma contraparte da linguagem, algo que terminaria por refletir a "ordem da consciência", uma das razões pelas quais o ápice dessa tendência é reconhecido no cinema estrutural.

O filme que, para Sitney, inicia a vanguarda americana é Meshes of the Afternoon (1943), de Maya Deren e Alexander Hammid. ${ }^{217}$ Ele compara essa colaboração à de Luis Buñuel e Salvador Dalí em Um Cão Andaluz (Un Chien Andalou, 1928), tanto em termos gerais, nos modos de expressão utilizados, como nos detalhes de algumas cenas. O filme de Buñuel e Dalí, de acordo com o princípio surrealista do "cadáver esquisito", buscaria combinar imagens tão díspares que nenhuma relação lógica pudesse ser feita entre elas. A insistência no aspecto irracional se estende ao próprio conteúdo dessas imagens: o trecho célebre em que Buñuel corta o olho de uma mulher com uma navalha é a primeira de várias cenas no filme que leva a exploração dos conteúdos inconscientes ao extremo no tratamento de uma convenção que é abruptamente invadida por elementos eróticos e violentos. Sua inspiração psicanalítica é evidente, justamente o que Sitney utiliza para diferenciar o filme de Deren e Hammid.

Há uma imagem que se repete nos dois filmes. No filme de 1928, um homem observa, pela janela, a movimentação das pessoas em uma rua, e tão logo surge a possibilidade de uma mulher ser atropelada, o comportamento dele se torna eufórico, como se estivesse extremamente excitado com a situação. No filme de 1943, Deren é vista se aproximando da janela de uma casa, encostando as mãos sobre o vidro e contemplando a paisagem externa numa postura mais contida. Ela observa a si mesma (uma "segunda" Maya Deren) correndo pelo caminho que leva até a casa, o caminho que ela (a "primeira" Deren) fez no minuto anterior. Sitney argumenta que as duas narrativas exploram conteúdos semelhantes através de uma evocação onírica, mas enquanto Um Cão Andaluz o faz através do choque, e de uma construção baseada na irrupção do elemento irracional de maneira violenta, Meshes of the Afternoon o faz de maneira reflexiva, através da condução da personagem por uma paisagem que é a própria expressão desses conteúdos.

As cenas no filme de Buñuel são repletas de objetos que se relacionam de maneira metafórica (o olho cortado pela navalha e a lua atravessada por uma nuvem, por exemplo), que surgem para imediatamente darem lugar a outros objetos; mas os objetos no filme de Deren são significados apenas em sua recorrência, como símbolos

${ }^{217}$ Cf. Sitney, Visionary Film, op. cit., pp. 3-15. 
daquele universo particular (a faca, o espelho). Da mesma forma, o espaço e o tempo do primeiro filme têm sua estabilidade quebrada ou desafiada em diversos momentos personagens aparecem, desaparecem, são substituídos; a porta do apartamento, que tinha vista para uma rua, se abre e revela uma praia; as cartelas interrompem as ações e embaralham a cronologia. No segundo filme, espaço e tempo dependem da trajetória da protagonista, de seu estado, de seus gestos - no início do filme, ela sobe as escadas em câmera lenta, em planos estáticos; em uma cena seguinte, ela sobe as mesmas escadas e a câmera a acompanha de modo que parece controlar todo o espaço da casa (a câmera gira em torno do seu eixo, e Deren é jogada em uma das paredes como se a própria casa estivesse girando). ${ }^{218}$ Diferente do surrealismo de Buñuel, o filme de Deren é o que Sitney chamou de filme de transe: uma encenação de conteúdos psicológicos através de símbolos, e da contaminação da própria realidade por esses conteúdos.

O filme de transe seria a primeira etapa da vanguarda americana em sua busca pela representação da consciência. Outros cineastas seguiram Deren nessa tendência, como Kenneth Anger (Fireworks, 1947), Gregory Markopoulos (Swain, 1950) e Stan Brakhage (The Way to Shadow Garden, 1954). Ainda próximos de uma estratégia de representação narrativa, esses primeiros filmes tornam irrelevante a questão de os conteúdos serem "reais" ou "ilusórios". Para os fins da encenação psicodramática, eles são a expressão imaginativa dos conteúdos através da realidade. O espaço é visualizado objetivamente, à maneira do realismo, mas a lógica que rege a composição, e que em última instância determina a relação entre diferentes espaços, é subjetiva.

É no cinema de Brakhage que vemos uma das primeiras transformações na constituição do espaço. Sitney exemplifica essa transformação no período entre Reflections on Black (1955), um dos poucos filmes sonoros de Brakhage, e Thigh Line Lyre Triangular (1961), passando por Window Water Baby Moving (1959):

O espaço pelo qual o sonâmbulo vagava nos primeiros filmes de Brakhage, que é basicamente o espaço realista que ele herdou dos Lumière, aquela longa diagonal, desaparece. [...] Em Thigh Line Lyre Triangular vemos um espaço radicalmente diferente. Passagens de tela preta, tela branca e pinturas manuais sobre a película transformam nossa percepção da profundidade. $O$ filme começa

${ }^{218}$ Cf. Sitney, "The Idea of Morphology", Op. cit., p. 6. "Meshes of the Afternoon se inspira no cinema onírico dos anos 1920, mas em vez de usar o sonho como uma explosão, uma bomba interna, tenta construir a partir do sonho uma forma [...]." 
com um borrão de tinta, esfregado sobre o filme, e desses campos pintados é criada uma profundidade através de imagens. [...] É interessante comparar Reflections on Black e Thigh Line Lyre Triangular a Window Water Baby Moving, o registro do nascimento do primeiro filho de Brakhage. [Em Window Water Baby Moving] há um diálogo entre ver o nascimento e o drama do nascimento. $\mathrm{O}$ espectador espera o nascimento de uma criança com a expectativa alegre do cineasta/pai. O cineasta parece estar prestes a transferir uma experiência dramática para uma [experiência] visionária. Em Thigh Line Lyre Triangular a cena é dissolvida em uma experiência visual misturando a realidade fotografada, pintura e imagens mentais. ${ }^{219}$

O que Brakhage desenvolve nos filmes desse período é o que Sitney chamou de filme lírico: um cinema que postula o cineasta por trás da câmera, em que não temos mais a mediação de um personagem, mas em que a tela, e tudo o que ela contém, se torna a expressão de sua trajetória. Por essa razão a movimentação da câmera é essencialmente feita pelo próprio cineasta, tomando-a em suas mãos para traduzir mais diretamente a extensão de seu corpo e olhar. ${ }^{220} \mathrm{O}$ movimento é constante, mas irregular; o espaço em perspectiva, com profundidade de campo, é possível, mas não se apresenta na totalidade do filme.

As intervenções diretas na película são um traço marcante de Brakhage, não necessariamente compartilhados por outros proponentes do cinema lírico. Podemos citar dois nomes que passaram pelo mesmo gênero, e que recorreram a outros procedimentos. Marie Menken, uma das influências de Brakhage, compõe em seu Notebook (1962) uma espécie de haikai cinematográfico, numa série de observações pontuais de objetos e eventos que parecem ter atraído sua atenção justamente por um caráter não-espetacular, como os traços da pintura tradicional japonesa que enfatizam o espaço vazio por sua contenção. Bruce Baillie, que em outros filmes é influenciado diretamente pelo lirismo de Brakhage, adota uma estratégia semelhante à de Menken em Mr. Hayashi (1961),

\footnotetext{
219 Ibid., pp. 11-12.

220 Já nos primeiros filmes Brakhage tem a visão, e mais ainda, a possibilidade de uma experiência visionária, como seu tema central. $\mathrm{O}$ tratamento do tema em seus primeiros filmes confirma a descrição de Sitney, e a adequação deste período ao filme de transe. The Way to Shadow Garden é a história de um homem que, para sair de um estado de agonia em sua casa, fura os próprios olhos e sai para o jardim: o filme passa para o negativo, e o homem finalmente consegue ver a paisagem com as cores invertidas. Reflections on Black tem um homem cego como protagonista, e em alguns momentos seus olhos são cobertos por riscos que Brakhage faz sobre a película.
} 
observando as ações cotidianas de um jardineiro. Nos dois casos, a ênfase recai no fato de que há alguém observando, que o registro daquelas ações é em si uma ação.

A etapa seguinte, da qual Brakhage também constitui um exemplo de transformação, é o filme mitopoético. Enquanto o filme de transe utiliza uma iconografia dependente dos conflitos pessoais representados, o filme mitopoético se volta para significados coletivos ou arquetípicos; não através de imagens derivadas de mitos específicos, mas por uma construção, uma estrutura na composição que remete a diferentes mitos, e que trabalha através das analogias entre eles (é nesse sentido que Sitney busca aproximar o filme de transe de uma inspiração freudiana e o filme mitopoético de uma inspiração junguiana, o que não significa que os cineastas se basearam nessas teorias).

Kenneth Anger faz a passagem do filme de transe para o filme mitopoético com Scorpio Rising (1963). Em vez da relativa unidade espacial pela qual o protagonista caminhava em Fireworks, Anger constrói aqui um espaço que contrapõe diferentes iconografias (as roupas de couro do motociclista, a suástica nazista) e figuras (Jesus, James Dean), num conflito constante. Não há mais a busca por identidade ou um espaço homogêneo, mas a apresentação de opostos em uma série de episódios, cada um deles marcado por uma canção diferente. O filme ainda remete a uma jornada, mas esta se dá por uma paisagem transfigurada, que parece ser a concretização de um terreno inconsciente, atravessada pela câmera.

O filme de Brakhage que representa sua maior exploração do gênero mitopoético é Dog Star Man (1962-64). Diferente do filme de Anger, a estrutura episódica é dispersa pela abordagem que Brakhage traz de sua incursão no cinema lírico. $O$ espaço representado em Scorpio Rising é construído por fragmentos, mas esses fragmentos são reconhecíveis, fazem parte de uma observação realista; em Dog Star Man "passamos das veias capilares a explosões no sol, imagens do [protagonista] em sua escalada, imagens de sua esposa, de sua família, das árvores, das montanhas, variações bruscas de espaço e escala". ${ }^{221}$ Sitney cita Ezra Pound para descrever a postura de Brakhage: "A imagem não é uma ideia. É um nódulo ou conjunto; é o que eu posso e devo chamar de vórtice, do qual, através do qual e pelo qual ideias estão constantemente passando".222

\footnotetext{
${ }^{221}$ Ibid., p. 17.

${ }^{222}$ Ezra Pound apud Sitney, Visionary Film, op. cit., p. 196.
} 
No desenvolvimento do que seria a "mímese da consciência", os três gêneros citados se afastam gradualmente da representação baseada nos princípios realistas. $\mathrm{O}$ filme de transe é como uma abordagem inicial do problema, uma tentativa de incluir na lógica dramática a experiência subjetiva. Existem referenciais mais ou menos claros, espaços uniformes e mesmo uma psicologia da narrativa, mas estes são articulados de modo a não reconstituir um desdobramento causal ou uma tentativa de integração à realidade objetiva. O filme lírico se livra da dramaturgia no sentido estrito através da identificação de todo o campo visível com a subjetividade por trás da câmera: o protagonista desaparece para que tudo se torne uma projeção da consciência do cineasta. O filme mitopoético busca organizar essa multiplicidade de imagens sob uma estrutura que funciona por comparações ou por ciclos, e que é um tipo de filtro sobre a realidade, a manutenção de uma progressão consciente revelada por uma articulação ainda mais presente. É importante notar que essa passagem se dá necessariamente em direção a uma maior identificação do espaço representado sobre a tela com o espaço limitado pelo quadro, pelo fotograma - o que remete ao que Frampton chamou do caráter metafórico do quadro, sua capacidade de constituir um ícone que separa o visível do invisível.

A etapa seguinte seria o que Sitney chamou de filme estrutural. O direcionamento descrito acima se mantém, e a mudança fundamental do filme estrutural é o repúdio à psicologia - que ainda existia no filme mitopoético, ainda que de maneira extremamente alusiva. $\mathrm{O}$ filme estrutural chama atenção, primeiramente, para sua forma geral, por não constituir uma progressão pela qual a consciência do espectador acompanha o trajeto de uma consciência análoga à do cineasta através de um protagonista, de uma câmera subjetiva ou de analogias. O que ocorre no filme estrutural é uma tentativa de fazer com que o próprio filme funcione como uma consciência autônoma. Não mais uma representação que possua conteúdos expressivos através de uma psicologia anterior; em vez disso, uma representação que se afirma como objeto, como um complexo autônomo, atraindo as atenções para si mesmo. Sitney identifica uma influência romântica nessa aspiração, na busca por uma obra que não quer se referir a nada, apenas a si mesma; uma obra que desafia a prioridade ontológica do objeto representado, e que, em última instância, quer apenas $\operatorname{ser}^{223}$

Um dos cineastas que prepara o terreno para o filme estrutural é Andy Warhol, especialmente em seus filmes que observam uma única ação por um enquadramento

${ }^{223}$ Cf. Sitney, "The Idea of Abstraction”, in Film Culture, no 63-64, 1976, p. 22-24. 
fixo durante vários minutos. Vemos em Eat (1963), por exemplo, uma pessoa comer um cogumelo por mais de quarenta minutos; em Sleep (1963), uma pessoa dormir por mais de cinco horas; em Empire (1964), o Empire State por mais de oito horas. O temperamento de Warhol é diferente dos cineastas que vieram a constituir o cinema estrutural (a ironia e as alusões de suas escolhas parecem dialogar mais claramente com seus filmes narrativos), mas os procedimentos básicos já se encontram em sua obra: a insistência em um número mínimo de técnicas, uma restrição extrema dos meios; uma sistematização dos aspectos envolvidos na observação das coisas ou da articulação delas; o isolamento ou abstração de seu pretexto, afastando possíveis integrações num nexo psicológico.

Zorns Lemma é um dos exemplos citados por Sitney, um dos filmes estruturais quintessenciais, em que as operações formais se evidenciam já no início, e o ato de "acompanhar" o filme se torna praticamente uma participação na articulação das imagens. O que num filme narrativo, dramático, ou mesmo lírico, se deve à apreensão do conteúdo das imagens para que a articulação delas ganhe sentido, no filme estrutural é devido principalmente à articulação - "como" passa a ser mais importante do que "o que". É interessante notar, neste ponto, como Frampton se relaciona com a descrição de Sitney. Nos filmes que sucedem Zorns Lemma, no ciclo Hapax Legomena, há uma insistência no jogo entre a estrutura e a narrativa, entre a construção abstrata, a identificação do filme à sua forma, e as referências propriamente psicológicas envolvidas nessa forma. A preocupação de Frampton com a linguagem é fundamental nesta passagem: nos três filmes analisados no capítulo anterior, é através do verbo que a psicologia da narrativa invade o filme.

Na medida em que o "conteúdo" perde importância no cinema estrutural, a asserção de Frampton de que não podemos diferenciar material original de material apropriado ganha um novo sentido. O cineasta que trabalha com o filme estrutural frequentemente utiliza imagens que não foram geradas por ele, pois o que atrai seu interesse não é a ressonância dessas imagens numa realidade externa integrada, ou mesmo numa representação de sua consciência através de um espaço lírico ou mítico; o que interessa é apenas como essa articulação revela, elabora e efetua "movimentos da consciência”. Dois exemplos definem mais claramente essa característica; ambos fazem uso de material de arquivo, mas levam esse material em direções distintas. 
Tom, Tom, the Piper's Son (Ken Jacobs, 1969) abre com a apresentação de um curta-metragem homônimo de 1906. Baseado em uma canção infantil, o curta envolve o roubo de um porco em uma feira e a eventual perseguição do ladrão, o personagem do título. A duração do curta é de aproximadamente 10 minutos, e sua composição reflete algumas das tendências da época: enquadramentos estáticos, amplos e frontais, por onde se desenrola toda a ação, mostrando certa influência do teatro, com os cortes surgindo apenas na passagem de um cenário a outro. Com o término da narrativa, Jacobs inicia uma série de intervenções enquanto repete trechos do material. Ele reduz a velocidade dos movimentos, recorta e muda a ordem das partes, refilma a imagem projetada, reenquadra os planos, evidencia a textura granulada, reorganiza a escala do espaço. Essas intervenções duram cerca de 90 minutos; em seguida, o curta é mais uma vez apresentado, sendo concluído com a revelação da própria superfície da tela envolvida na projeção, atacada continuamente pela luz em intervalos regulares.

O princípio que rege a composição do filme de Jacobs é o da variação. Um tema é apresentado, desenvolvido, tem suas propriedades transpostas para outras dinâmicas e parâmetros, e é por fim retomado na conclusão - devidamente alterado pelas experiências anteriores, como um personagem no término de uma jornada. O curta é apresentado integralmente, tempo e espaço são nele apreendidos de acordo com os parâmetros narrativos propostos já em 1906, a dinâmica dos elementos respeitando a estrutura original. Mas com as intervenções, Jacobs não apenas desvia as proposições originais como as leva ao paroxismo. Tempo e espaço não são simplesmente distorcidos, mas constantemente analisados como tópicos composicionais. A narrativa não é apenas desconstruída, mas exposta fora da cadeia de causas e efeitos para que seus elementos possam ser percebidos com uma autonomia local, em vez da autonomia global à qual se submetiam narrativamente. O que é desenvolvido é precisamente a gama de possibilidades da composição original: ao transformar o material fílmico em tema, a complexidade do estilo do passado é confrontada com a identidade imediata do presente. Nas palavras de Jacobs:

Eu procurei "trazer à superfície" a conflituosa colisão multi-rítmica de luz e sombra, áreas e forças bidimensionais lutando no limite por uma identidade de forma... para conseguir o próprio padrão microscópico do grão - uma dispersão química única a cada fotograma, cada fotografia... trazida à vida por uma 
sucessão de 16-24 f.p.s., padronizando sobre nossas retinas as energias reveladas [...] e então colaborando, inconscientemente e ironicamente, para formar a sempre tocante, porque sempre passada, ilusão. ${ }^{224}$

Eureka (Ernie Gehr, 1974), por outro lado, consiste em um único plano, um travelling frontal através da Market Street de São Francisco, também filmado em 1906. O bonde sobre o qual a câmera se posiciona atravessa toda a extensão da rua, enquanto esta é cruzada por pedestres e outros veículos. O material do qual o filme se apropria dura aproximadamente cinco minutos, e corresponde a um exemplar dos registros urbanos, comuns no início do século, que utilizavam meios de transporte para posicionar a câmera, integrando-a ao espaço e ao movimento natural da cidade. $\mathrm{O}$ plano é retomado por Gehr, que repete cada fotograma de seis a oito vezes, estendendo a duração para cerca de 40 minutos, enquanto altera os contrastes e flutuações de luz. A representação do movimento é reconfigurada pela extensão temporal, e os riscos na superfície da película são multiplicados e mais claramente percebidos. No decorrer do travelling, torna-se visível o Ferry Building, a grande estrutura vertical para a qual tende o trilho do veículo, e em frente à qual a câmera estaciona no final do plano.

Ao contrário do filme de Jacobs, em Eureka não vemos o plano original, apenas sua recomposição. O material não é variado, mas sua continuidade é dilatada a partir de seus elementos fundamentais - os fotogramas -, criando uma linha discreta que mantém a estrutura inicial, o movimento gradual no espaço em profundidade, mas possibilita sua articulação em um nível mais específico.

Um plano pode ser um filme, ou um filme pode ser composto por um número de planos. Uma foto, em relação a um filme, se direciona a usar e perder a imagem de algo através do tempo e espaço. Em filmes representativos a imagem às vezes afirma sua própria presença como imagem, como entidade gráfica, mas na maior parte serve como veículo para um evento registrado fotograficamente. Filmes de vanguarda tradicionais ensinam a ver o filme como uma imagem, uma representação. Mas o filme é uma coisa real e como coisa real não é imitação. Não reflete a vida, mas incorpora a vida da mente. ${ }^{225}$

\footnotetext{
224 Jacobs apud Sitney, Visionary Film, op. cit., p. 345.

225 Gehr, "Program notes by Ernie Gehr", in Film Culture, no 53-55, primavera de 1972, pp. 36-37.
} 
Em Eureka, o plano é sinônimo do filme. A repetição dos fotogramas afirma a presença de cada um deles como entidade fotográfica, composições congeladas no tempo, tornando evidentes suas propriedades gráficas. Mas a manutenção do movimento dentro do plano, especialmente o movimento com frequência e direção claramente determinadas, também torna evidente o caráter de representação de um evento registrado. É essa tensão entre a superfície e a profundidade, entre a imagem congelada e a imagem fugidia, que é modulada por Gehr sobre a estrutura do plano.

O “tema” de Tom, Tom, the Piper's Son não é a narrativa elaborada pelo curtametragem, mas o filme, o material apropriado. O que retorna no final, alterada como um personagem no término de uma jornada, é a organização daqueles fotogramas, aquela estrutura visual e rítmica que serviu de base para as variações de Jacobs, como uma matriz composicional. É o que Gehr enfatiza quando diz que “o filme é uma coisa real". Essa coisa real pode se servir de algo que não a si mesmo, pode ser gerado através de uma relação fotográfica com a realidade cotidiana, mas isso não anula a realidade do meio.

Em Serene Velocity (1970), Gehr fotografa várias vezes um corredor por um mesmo ângulo, alterando a abertura da lente para que cada fotograma seja o registro do mesmo espaço por diferentes configurações. A câmera permanece imóvel; Gehr registra quatro fotogramas em uma configuração e segue para a próxima, mantendo rigorosamente este método. $\mathrm{O}$ filme começa alternando padrões de quatro fotogramas a aberturas de $50 \mathrm{~mm}$ e $55 \mathrm{~mm}$, até que o intervalo passa para $45 \mathrm{~mm}$ e $60 \mathrm{~mm}$; em seguida, para 40mm e $65 \mathrm{~mm}$, e assim por diante, numa progressão contínua nas duas direções, sem quaisquer outras articulações. ${ }^{226} \mathrm{O}$ corredor permanece o mesmo por toda a duração, enquadrado simetricamente, com as luzes e paredes em perspectiva formando uma série de quadrados. O ritmo não é alterado, mas há uma progressão devido à distância crescente entre as aberturas. Gehr não permite que o espaço seja experimentado fora dessa estrutura: o que ele nos dá é um espaço-tempo fílmico, que existe unicamente na projeção de sua composição. Um espaço que não permite a manutenção da ilusão de profundidade, mas também não permite a dissociação das formas superficiais de seu referencial fotográfico; um tempo que não acomoda referências humanas, e que pela fragmentação do registro não constrói uma continuidade, mas que, mantendo o mesmo padrão de alternância de fotogramas,

${ }^{226}$ Cf. Sitney, Visionary Film, pp. 400-401. 
constrói um ritmo próprio. É nesse sentido que podemos ver o tema de Serene Velocity como sendo "a relação espacial e temporal entre o espectador e a imagem na tela. A fonte de poder e um tipo de energia que pulsa pelo espaço do projetor à tela e da tela à mente. O único feixe de luz do projetor. Estatismo e estímulo sobre os quais a consciência oscila tanto quanto o filme". ${ }^{227}$

Noel Carroll caracteriza o filme de Gehr como análogo aos "experimentos de pensamento" na filosofia. ${ }^{228}$ A ênfase no processo de percepção das características básicas da composição é o que ele diz ser um caminho para que o filme seja em si um processo de pensamento, e não um veículo para um pensamento. Um metafilme: uma proposição sobre a natureza do cinema, através do cinema. Ao rejeitar a psicologia, a profundidade e interdependência dos eventos, o filme estrutural se volta à epistemologia, à superfície dos eventos, sua dependência das categorias materiais do cinema e as categorias da própria percepção do espectador.

\section{O domínio da visão}

A introdução usual à obra e às preocupações de Stan Brakhage é o texto "Metáforas da Visão", que ocupa um lugar central em seus escritos, como um manifesto do qual ensaios e declarações posteriores parecem surgir como desdobramentos. O parágrafo inicial evoca alguns de seus filmes pelas imagens descritas, bem como o tom poético e a aspiração romântica:

Imagine um olho não governado pelas leis fabricadas da perspectiva, um olho livre dos preconceitos da lógica da composição, um olho que não responda aos nomes que a tudo se dá, mas que deve conhecer cada objeto encontrado na vida através da aventura da percepção. Quantas cores há num gramado para o bebê que engatinha, ainda não consciente do "verde"? Quantos arco-íris pode a luz criar para um olho desprovido de tutela? Que consciência das variações no espectro de ondas pode ter tal olho? Imagine um mundo animado por objetos

\footnotetext{
${ }^{227}$ Gehr apud Sitney, Eyes Upside Down, p. 206.

${ }^{228}$ Cf. Carroll, "Philosophizing through the Moving Image: The Case of Serene Velocity", in The Journal of Aesthetics and Art Criticism, vol. 64, $\mathrm{n}^{\circ}$ 1, inverno de 2006, pp. 173-185.
} 
incompreensíveis e brilhando com uma variedade infinita de movimentos e gradações de cor. Imagine um mundo antes de "no princípio era o verbo". ${ }^{229}$

O que Brakhage idealiza é algo que parece ter uma ligação com o projeto de Frampton de uma contraparte da linguagem, algo que vá além dos seus limites, além da articulação de um discurso verbal. A crença subjacente é a de que a transcendência da linguagem traria a possibilidade de alcançar áreas mais amplas para a expressão - nas palavras de Frampton, mais ambíguas em seu sentido, mais compactas em sua síntese. Essa crença é depositada necessariamente em uma transcendência, e não em um retorno. Brakhage enfatiza que "não se pode nunca voltar atrás, nem mesmo na imaginação. Depois da perda da inocência, somente o conhecimento total pode nos compensar". Ele sugere "uma busca de conhecimento fora da língua, baseada na comunicação visual, solicitando a evolução do pensamento ótico e confiando na percepção no sentido mais profundo e original da palavra". ${ }^{230}$

Mas as diferenças entre o projeto de Brakhage e o de Frampton são instauradas já de início. Em primeiro lugar, Brakhage se volta completamente para o desenvolvimento da visão: seus filmes, com raras exceções a partir da primeira fase formativa, são desprovidos de qualquer faixa sonora. $\mathrm{O}$ som, um elemento de interesse elevado para Frampton, é tido por Brakhage como um invasor ou uma distração, algo essencialmente desligado das preocupações visuais. Em segundo lugar, Brakhage é avesso a qualquer tipo de "linguagem cinematográfica", qualquer tentativa de organização das possibilidades expressivas. Ao temperamento sistemático de Frampton, e à tendência a integrar estruturas geradoras aos filmes - em que os sentidos e as formas são controlados ainda que pra apontar os paradoxos de sua construção -, ou seja, à confiança em uma ordem de ideias, Brakhage opõe uma sensibilidade que aspira justamente ao desprendimento e à abertura. ${ }^{231}$ Ele fala sobre "esquecer a ideologia", "negar a técnica", ser contra "qualquer progressão conhecida" ou qualquer "formação

${ }^{229}$ Stan Brakhage, "Metáforas da Visão", in Ismail Xavier (org.), A Experiência do Cinema (São Paulo: Graal, 2003), p. 341. Originalmente em Brakhage, Metaphors on Vision (Nova York: Film Culture, 1963).

${ }^{230}$ Ibid.

${ }^{231}$ Frampton comenta em uma entrevista que Sitney teria se referido ao seu uso da câmera como uma "retórica ótica suntuosa". Em seguida ele sugere que Brakhage provavelmente se sentiria "extremamente desconfortável com a sugestão de que sua cinematografia, sua diç̧ão, seu vocabulário com a câmera fosse de alguma maneira retórico, ou que fosse escolhido deliberadamente, por uma razão particular”. Ver “Talking About Magellan”, in Jenkins, Op. cit., p. 247. 
lógica" - para ele, só são bem-vindos os gestos que traduzem a infinidade de possibilidades, ainda que isso inclua o caos. ${ }^{232}$

Disso decorrem suas sugestões de como se pode ir contra a construção enviesada do aparato fílmico, moldado pela herança renascentista. Para se livrar dessas amarras, o cineasta pode cuspir nas lentes, destruir o mecanismo de foco, alterar a velocidade da câmera, subexpor e superexpor os filmes, usar filtros naturais (água, neblina) e artificiais, ignorar as especificidades dos negativos ou da fotometria, etc. $\mathrm{O}$ estatuto da ilusão realista é interpretado por Brakhage como resultado de convenções; ele lembra que a projeção de Nanook era apenas um jogo de luzes e sombras para os esquimós. A convenção limita a percepção, e o realismo é visto como uma invenção, não uma "tradução" da realidade.

Se o olho fosse mais sensível, perceberia a cada segundo de projeção o truque dos vinte e quatro quadros, com igual número de intervalos negros. Que filmes incríveis poderiam ser feitos para tal olho! o equipamento, porém, já foi construído para ludibriar até mesmo tal sensibilidade [...] Oh, espectador de olhos lentos, a máquina do cinema tritura a sua existência! ${ }^{233}$

A concepção de realismo de Brakhage é bastante particular, ligada a seu desejo de incorporar a totalidade das possibilidades visuais. O "absoluto realismo" no cinema seria para ele uma via diferente da convenção, da representação tradicional:

Meu elogio se dirige à sua ciclópica penetração na neblina, sua capacidade visual infravermelha quando no escuro, sua recém desenvolvida visão em 360 graus, sua revelação prismática do arco-íris, seu potencial de aproximação que faz explodir espaços e sua compressão "telefótica" que achata a perspectiva, suas revelações micro e macroscópicas. Admiro sua personalidade Schlaeriana, capaz de representar as ondas de calor e as pressões do ar mais invisíveis, e exalto os aperfeiçoamentos da câmera fotográfica que podem ser aplicados ao movimento. Exalto o seu tornar visível a irradiação de calor do corpo, sua adaptação ao ultravioleta, aos parâmetros da percepção humana, seu penetrante Raio X. Meu sonho é com a câmera misteriosa, capaz de representar graficamente a forma de um objeto depois de ele ter sido removido do espaço

\footnotetext{
${ }^{232}$ Brakhage, Op. cit., p. 344.

233 Ibid., pp. 347-348.
} 
do registro fotográfico... O "absoluto realismo" do cinema é uma não realizada, logo potencial, magia. ${ }^{234}$

Em outras palavras, um realismo que busca se reportar à verdade do sentido da visão, mais do que a qualquer concepção de mundo. A unidade do mundo de Bazin e a transparência de uma câmera que revela as ambiguidades fundamentais através das aparências são insuficientes para Brakhage. A objetividade fotográfica para ele deve ser total: nada que pertença ao domínio da visão deve ser excluído. Se algo pode ser visto, se pode ser registrado pela câmera como a fixação desse processo visual, então deve ser considerado. $^{235}$

Um desdobramento disso é o crescente interesse de Brakhage, no decorrer de sua carreira, em representar filmicamente o que ele chamou de "visão de olhos fechados" formas que vemos efetivamente, mas em condições não-usuais, como quando esfregamos os olhos com as mãos e percebemos cores e figuras sob as pálpebras, ou quando entramos num estágio onírico ou mesmo sonolento. É para atingir um resultado aproximado dessas imagens que Brakhage decide intervir diretamente na superfície da película, com pinturas, desenhos, riscos, sobreposições, combinando essas operações com as imagens filmadas, e controlando as diferentes camadas como melodias numa composição musical. ${ }^{236}$

Ele diz que uma obra deve "definir um paradigma do caos experimentado na vida cotidiana enquanto é em si uma construção um tanto diferente dele”. Em outras palavras, deve ser fiel ao espírito dessa vida, não às suas aparências. Brakhage concorda em parte com o objetivo de Bazin, mas discorda quanto ao caminho adotado. Como exemplo desse processo, ele cita uma composição feita com tintas aplicadas à película, a partir da visualização de um objeto qualquer, como uma alface sobre uma mesa. As

\footnotetext{
${ }^{234}$ Idem, p. 352.

${ }^{235}$ Uma frase de James Broughton em High Kukus (1973) parece sintetizar parte da postura de Brakhage: "Para onde quer que você olhe, disse a câmera, é assim que as coisas são".

${ }^{236}$ Ver a entrevista de Brakhage a Sitney em Film Culture Reader (Nova York: Cooper Square, 2000), p. 223. É interessante sobre a comparação musical o fato de que Brakhage já no início de sua carreira optou por filmes silenciosos. Ele comenta que é precisamente por se interessar pela música e por ela constituir uma de suas maiores fontes de inspiração que ele prefere manter o som como algo à parte $\mathrm{e}$ pensar a criação visual de maneira análoga. Brakhage comenta também que mesmo em cineastas silenciosos como Méliès e Griffith havia uma concepção sonora na imagem, uma compreensão do "sentido sonoro" sugerido pela visão, uma concepção que ele considera superior àquelas que surgiram no cinema falado. Cf. "The Silent Sound Sense", in Film Culture, no 21, verão de 1960, pp. 65-67. Para mais sobre a importância da música na composição de seus filmes, ver Marie Nesthus, "The Influence of Olivier Messiaen on the Visual Art of Stan Brakhage in Scenes from Under Childhood, Part One", in Film Culture, n 63-64, 1976, pp. 39-50.
} 
pontas e ângulos da alface podem ser "traduzidos" em termos musicais, em uma instrumentação específica (como golpes de pizzicato, ou curvas tonais); pintar essas qualidades sobre o filme seria absorver o que pode ser visto do objeto, seus arredores, ao mesmo tempo em que considera o movimento da própria absorção do objeto pela consciência, as alterações que constituem a contemplação, a passagem da dimensão visual à musical e desta novamente para o visual estruturado na faixa de filme. As tintas, as cores dispostas sobre a película, seguem então a própria subjetividade do cineasta. Resta ao final do trabalho pouco do objeto como percebido inicialmente, mas uma maior proximidade do "pensamento visual" suscitado por ele. ${ }^{237}$ A composição de um filme, para Brakhage, parece ser como uma fórmula química, designando uma determinada substância, mas não contendo o que a observação direta nos mostra dela: não um reflexo da percepção sensível fixada no objeto, mas a linha diretriz do movimento dessa percepção.

Para definir mais claramente sua postura, Brakhage diferencia dois modos de pensamento visual, que ele chama de "geométrico" e "carnal-inefável”. O primeiro seria aquele dependente de uma tendência a perceber energias naturais como formas, absorvendo a multiplicidade sensorial através de aproximações de ideais geométricos ele considera que a linguagem é um desdobramento deste modo, uma evolução das "geometrias do pensamento". O segundo modo seria uma espécie de antídoto à rigidez, numa inclinação à mímese das formas variáveis que resistem tanto à nomenclatura como à geometrização, numa busca por maior organicidade. ${ }^{238}$

Se uma imagem é definida como "uma coleção de formas nomeáveis dentro de um quadro", Brakhage diz que ela pode ser vista como os processos indefiníveis a serem expressos pela consciência "inefável”. Mas se essas formas ocorrem numa composição, geralmente são regidas por uma lógica, que implica uma geometria, pois esta ordenação se refere ao mundo exterior por sua "autoridade formal" (lembremos do que Mitry chama de "o referencial absoluto" do quadro, que estabelece uma unidade à parte da realidade em que os objetos se encontram originalmente). Ele cita então exemplos de pintores que abordaram relações possíveis entre os dois modos. Hans Hoffman o faria especialmente em suas obras que misturam retângulos e formas orgânicas que parecem resistir a qualquer ordenação geométrica. Rothko seria outro

\footnotetext{
${ }^{237}$ Cf. Brakhage, "Painting Film", in Eirik Steinhoff (ed.), Stan Brakhage: Correspondences (Chicago Review, 2001), pp. 61-63.

${ }^{238}$ Cf. Brakhage, "Geometric versus Meat-Ineffable", in Steinhoff, Op. cit., pp. 47-48.
} 
exemplo, construindo retângulos que em seu interior possuem variações sutis de tonalidade e textura. Kandinsky e Mondrian seriam dois exemplos de artistas que realizaram uma aproximação gradual de um dos lados: partindo da visão orgânica, chegaram à visão geométrica. ${ }^{239}$

No cinema, Brakhage argumenta que existe uma tendência natural à "grade" geométrica. Mas ainda que a câmera e as lentes se aproximem da perspectiva tradicional, o fato é que todo filme se resolve, fundamentalmente, num jogo de sombras. A ilusão de movimento, assim como a ilusão de profundidade, depende da pulsação interna da tela, que resulta da alternância entre formas luminosas projetadas sobre ela, entrecortadas por períodos em que nenhuma luz atinge a tela. No momento em que um movimento é congelado, ele se torna uma forma achatada, independente das tentativas da iluminação ou da encenação de sugerir algum volume. O caminho usual para eliminar essa organicidade no cinema seria a eliminação dos aspectos superficiais do material: a diminuição ou neutralização da visibilidade dos próprios grãos que constituem a película, que, sendo diferentes de um fotograma a outro, são como células que formam o organismo da imagem. É apenas com a superfície tornada transparente que a imagem pode ser considerada uma janela para o mundo sensível, organizado como um espaço uniforme. O que Brakhage defende, como Frampton, é que essa abordagem é apenas uma das possibilidades. A “arte abstrata", para ele, é real no sentido que expõe algo que resiste à idealização, ou seja, que tende ao pensamento carnal-inefável. $^{240}$

A maior proximidade de Frampton com as estruturas linguísticas, além de seu temperamento sistemático, é o ponto que marca a diferença básica entre suas aspirações e as de Brakhage. Há alguma aproximação, pois ambos consideram que o objetivo superior do cinema deve ser o de constituir uma contraparte da linguagem; mas enquanto Frampton parece propor uma passagem pelo terreno da linguagem, Brakhage busca se situar fora deste, como se seus aspectos devessem ser negados de início. Em um ensaio que compara a obra dos dois cineastas, Annette Michelson cita uma expressão de Brakhage, que se refere a Frampton como alguém que "filtra o cinema pela linguagem". ${ }^{241}$ É nesta chave que o diálogo entre ambos é desenvolvido no decorrer dos anos, incluindo filmes que são praticamente respostas às obras um do

\footnotetext{
239 Ibid., pp. 48-49.

240 Ibid., p. 51.

241 Annette Michelson, “Frampton's Sieve”, in October, n 32, primavera de 1985, p. 151.
} 
outro: se Frampton em Zorns Lemma parte da linguagem e de um esquema rítmico determinado com rigidez para chegar ao plano final, contínuo e dissolvido pela luz, Brakhage compõe The Riddle of Lumen (1972), completamente tomado por essa luz, sem uma grade rítmica reconhecível ou associada a qualquer forma geral, com a modulação luminosa sendo a linha mestra. O título se refere ao princípio de associação alusivo, não baseado em categorias lógicas ou métricas, mas voltado inteiramente para as qualidades de cor, forma, saturação, profundidade e movimento. ${ }^{242}$

Michelson identifica em Hapax Legomena o ponto de maior concentração da preocupação de Frampton com a relação entre a linguagem e a imagem. Enquanto Zorns Lemma propunha a passagem gradual de uma esfera à outra, os filmes seguintes se colocariam na interseção dos dois eixos, no que ela chama de "cristalização de uma temática dupla de violência na linguagem e no erotismo". Uma violência que, como vimos, é infligida diretamente na imagem, seja ela uma fotografia (Nostalgia) ou uma cena (Critical Mass). Uma linguagem que pode ser a de uma voz sem corpo (Nostalgia), de vozes encarnadas (Critical Mass) ou de um texto a ser lido (Poetic Justice). E finalmente, um erotismo que é tanto de uma ênfase no deleite sensorial, na exuberância física do que se contorce sobre a tela, uma fotografia incinerada ou um casal que repete obsessivamente cada gesto; ou o erotismo que resulta dos conflitos desenvolvidos pela fagulha narrativa que surge principalmente em Critical Mass e Poetic Justice. Neste último, há toda uma arquitetura mental, na relação entre a câmera e o espaço, entre o espaço e seus entornos, entre a cena e o tempo das ações, e principalmente entre os agentes dessas ações - uma tensão que não deve se resolver sobre o plano da imagem ou sobre o plano imaginário, mas permanecer entre eles, como entre os tempos verbais da história. $^{243}$

Isso não significa que a obra de Brakhage seja desprovida de referências narrativas. Seus primeiros filmes, como lembrado por Sitney, se integram claramente às tendências da época, ao que era feito por Maya Deren ou Kenneth Anger - filmes em que o objetivo era efetuar a mímese da consciência através de um protagonista, visto como a projeção do cineasta num espaço ilusionista. A passagem desse período para uma maior abstração (ou, talvez devamos dizer, um direcionamento ao modo "carnal-

\footnotetext{
${ }^{242}$ Cf. Sitney, Visionary Film, op. cit., p. 388.

243 Cf. Michelson, "Frampton's Sieve”, Op. cit., pp. 160-163.
} 
inefável”) coincide com a aceitação do que Brakhage descreveu como sendo as qualidades orgânicas do material fílmico.

O filme-chave desta etapa é Dog Star Man. Diferente dos outros filmes feitos por Brakhage na sua primeira década, este é um filme mais longo, dividido em cinco partes. Dog Star Man é a convergência de suas preocupações que antes se encontravam dispersas, em uma forma que possui fragmentos de uma narrativa, mas quase como pontos de partida, ou uma estrutura subjacente sobre a qual o filme é elaborado. Essa narrativa é a de um homem (interpretado pelo próprio Brakhage) que sobe uma montanha empunhando um machado, acompanhado de seu cachorro, para derrubar uma árvore. Uma história extremamente compacta, como um drama de um único movimento, mas que é expandido e considerado por diferentes ângulos.

Sobre alguns aspectos da composição, um comentário de Brakhage parece apontar para algo como uma matriz geradora no interior da obra, confirmando a descrição de Sitney para o filme mitopoético:

Eu concebi Dog Star Man como estruturado através das estações; mas também, compreendendo um ano e a história do Homem em termos de material visual (por exemplo, as árvores se tornam a arquitetura de toda uma história de monumentos religiosos, ou a violência se torna o desenvolvimento da guerra), eu pensei que deveria ser contido em um único dia. ${ }^{244}$

Este é um dos primeiros filmes em que Brakhage faz uso das intervenções na superfície da imagem de maneira constante, ainda que com imensa variedade de efeitos. No filme, os riscos, manchas e rastros de tinta interagem com as imagens filmadas, que são por vezes sobrepostas, multiplicando os materiais visíveis. Vemos um plano em que Brakhage sobe a montanha em câmera lenta, a angulação um tanto oblíqua, mas a ação perfeitamente reconhecível; o plano é entrecortado por uma série de imagens breves, imagens de arquivo de explosões solares, com o contraste elevado, fazendo com que o sol se torne um semicírculo branco sobre um fundo negro, a mesma imagem sendo reafirmada em diferentes posições. Vemos em seguida planos próximos, detalhes de corpos, planos desfocados, manchas que parecem flutuar sobre a tela; traços que atravessam a tela rapidamente sobre nuvens, e o que parecem ser rachaduras na película.

244 “Interview with Stan Brakhage", in P. Adams Sitney (ed.), Film Culture Reader, op. cit., p. 223. 
As imagens surgem da escuridão e retornam a ela diversas vezes, o ritmo dessas passagens sendo conduzido tanto pela velocidade interna de cada imagem como pela quantidade de camadas e suas combinações.

A concepção de Frampton da narrativa como uma inevitabilidade, em seu sentido mais abstrato, é crucial para entender o desenvolvimento da filmografia de Brakhage. A partir dos anos 60, seus filmes se tornam cada vez mais desprendidos das estruturas dramáticas tradicionais. É nesse sentido que Dog Star Man parece um ponto de passagem, a interação entre o material filmado e as intervenções diretas na película, entre uma geometria da estrutura composicional e uma sensibilidade "inefável" que parece guiar todo o filme num fluxo incessante. O que se segue, especialmente nas duas últimas décadas da vida de Brakhage, é uma recusa quase total do material filmado, e uma preferência pelas diversas maneiras de pintar e riscar a faixa de filme, bem como alterar seus aspectos superficiais com os químicos da revelação.

Mesmo nos filmes desse período em que Brakhage aceita a presença de material filmado, ele o faz seguindo outra postura que não aquela de Dog Star Man. Em Commingled Containers (1994), ele elabora um verdadeiro estudo sobre a água em suas diferentes manifestações. As imagens reconhecíveis de córregos e bolhas, vistas em planos extremamente próximos, são entrecortadas com imagens cujo movimento geral percebemos estar relacionado ao "tema", mas do qual não temos qualquer referencial externo. O filme mistura diferentes modos pictóricos, indo das manchas de tinta sobre o fotograma aos planos mais realistas, passando por imagens que parecem ter sido registradas por filtros, lentes de aumento e outros instrumentos. A água "real” e a "água pintada" tornam-se uma só, e o movimento compartilhado por elas é o movimento construído pelo filme.

A partir do momento em que se desprende da lógica geométrica, da causalidade ou de estruturas dramáticas, Brakhage deve buscar outras maneiras de compor seus filmes. Ele aspira a certa musicalidade, à concepção do cinema como o movimento da luz no tempo. Sobre essa questão, podemos citar uma comparação feita por Paul Valéry, entre a música e a arquitetura, em suas qualidades não-significativas:

Assim como um músico, enquanto compõe, imagina algo que não é música para dar à obra sentido, tom e uma lei de desenvolvimento, e constrói e descobre para si próprio uma história, um sentimento - e da mesma forma que um 
virtuoso executando esta obra irá, por sua vez, se equipar com algo que anima e humaniza sua performance -, assim também um arquiteto (que pratica uma arte que é inerentemente não-significativa) busca algo para ir do arbitrário ao necessário. [...] A história ou sentimento do arquiteto, que irá dar a seu plano uma qualidade de discurso ou de canto [...] e não uma combinação de partes aproximadas, deve ser buscada em uma modulação particular, sutil, e numa harmonia entre os diferentes elementos, combinados por uma intenção que não é estritamente visual ou motora - uma sensibilidade geométrica das direções, extensões e ligações de figuras, dadas as formas, linhas, superfícies, etc., valores que as diferenciam; um sentimento por cores, sombras, um reconhecimento de massa. Tudo isso acompanhado por uma noção de construção. $^{245}$

A descoberta de "uma história, um sentimento" parece ser uma abordagem próxima da de Brakhage, inclusive de sua herança romântica, mais claramente entendida em seus primeiros filmes: a identificação do universo filmado com a expressão do protagonista, ou o uso da câmera subjetiva como ferramenta lírica, identificando cada movimento, e cada deformação nas cores ou no espaço com um movimento da consciência. Valéry se refere à "geometria" da arquitetura, o que se aproxima da estrutura matemática das escalas e da série harmônica na música, algo que Brakhage provavelmente apontaria como fora de sua área de interesse, se consideramos suas declarações e textos. Sua "noção de construção" talvez esteja para a noção geométrica de Valéry como o modo geométrico de montagem está para o modo linear que Sitney cita para descrever o cinema de Bresson. Mas enquanto Bresson utilizaria a metonímia e o contraponto entre som e imagem para sugerir um mundo calcado no real, e apresentado segundo uma organização de acontecimentos que contém como que "dentro deles", o movimento de uma psicologia que é propriamente dramática, Brakhage busca o desprendimento das figuras de linguagem, as leis do movimento enquanto tal, das luzes e cores enquanto tais, da imagem enquanto tal.

${ }^{245}$ Valéry, in Stimpson, Op. cit., pp. $72-73$. 


\title{
III. Variações sobre espaço e linguagem
}

Annette Michelson começa um texto sobre a obra de Michael Snow se referindo ao mesmo tópico identificado por Sitney como central no cinema de vanguarda como um todo: a representação da consciência. Segundo ela,

\begin{abstract}
existem obras cinematográficas que se apresentam como análogas da consciência em seus modos constitutivos e reflexivos, como se a investigação da natureza e do processo da experiência tivessem encontrado na arte deste século um modo de apresentação único, contundente, direto. O ilusionismo da nova arte temporal reflete e ocasionalmente reflete sobre, as condições do conhecimento; facilita um foco crítico sobre o imediato da experiência no fluxo do tempo. ${ }^{246}$
\end{abstract}

A obra de Snow é apontada como sendo paradigmática nesse sentido. Um dos principais nomes do cinema estrutural, compartilhando as aspirações descritas por Sitney, em seus filmes "a investigação epistemológica e a experiência cinematográfica" finalmente convergem "em mímese recíproca”. 247

A filmografia de Snow possui duas vertentes convencionalmente identificadas como sendo, de um lado, a exploração de movimentos de câmera, sistematizados e repetidos com insistência por toda a duração da obra, e de outro, a investigação de relações entre som e imagem, o que inclui aspectos da linguagem verbal.

Em Back and Forth (1969), Snow apresenta uma série de panorâmicas realizadas numa sala de aula, em planos longos, enquadrando alternadamente dois dos seus cantos. ${ }^{248}$ Ao mesmo tempo em que pessoas entram e saem da sala, a câmera aumenta ou diminui a velocidade do movimento, de forma que há um ritmo próprio da câmera que se mantém mesmo quando a sala está vazia. Em alguns momentos essas operações são completamente independentes, mas em outros elas parecem convergir, como se a densidade do espaço, o número de pessoas concentradas em seu interior, influenciasse a câmera e diminuísse sua velocidade - como se a panorâmica devesse

\footnotetext{
246 Michelson, "Toward Snow", in Sitney, The Avant-Garde Film, op. cit., p. 172.

247 Ibid., p. 173.

248 O título original do filme é uma imagem formada por duas setas horizontais em direções opostas. Nos textos aqui utilizados, ele é referido como 〈--->. No decorrer da dissertação, foi preferido o título alternativo, em extenso, utilizado pelo próprio Snow.
} 
atravessar um volume maior de matéria para chegar ao outro lado. Esse sistema revela não apenas uma modulação da relação entre o ponto de vista e o espaço, mas também entre as diferentes propriedades da imagem: quando a movimentação da câmera é lenta, reconhecemos os detalhes da sala em foco, mas quando o movimento é acelerado esses detalhes se tornam manchas abstraídas sobre a superfície do filme.

A recorrência do mesmo procedimento é uma das estratégias identificadas por Sitney como características do cinema estrutural. Ao fixar um aspecto da representação, Snow cria uma espécie de escala sobre a qual o espaço passa a ser medido. ${ }^{249} \mathrm{O}$ posicionamento da câmera inicialmente parece refletir a constituição da sala, da qual reconhecemos apenas o espaço descrito pelas panorâmicas; mas dentro deste espaço, o que Snow realiza é uma demonstração de diferentes possibilidades rítmicas e dinâmicas. A interação entre a câmera e o espaço é a própria matéria do filme. Tudo o que existe no interior do quadro em Back and Forth, mesmo as formas mais sólidas, se reduz a energias moduladas num mesmo campo.

La Région Centrale (1971) faz uso de uma grua construída por encomenda, e estende essa modulação a combinações entre os eixos vertical, horizontal e ao redor da própria lente. Com a grua fixada no topo de uma montanha, a câmera realiza movimentos a partir de um controle previamente estabelecido por Snow. Os planos, de durações variadas, são então ordenados e separados por curtos intervalos em que apenas um $X$ luminoso é visto sobre a tela escura. O princípio é semelhante ao de Back and Forth, com a movimentação da câmera funcionando como uma descrição e interpretação do espaço. Mas as diferenças são fundamentais. Em primeiro lugar, o espaço de Back and Forth é fechado, marcado por uma arquitetura específica, que parece servir de referência e limite para a própria movimentação, enquanto o espaço de La Région Centrale é um paradigma de abertura e amplitude, uma plataforma com vista para a imensidão do céu e do horizonte. Em segundo lugar, a sala em Back and Forth é um cenário de objetos e eventos culturalmente determinados, e que por vezes parecem interagir com a articulação da câmera; mas a paisagem em La Région Centrale é desprovida de qualquer elemento humano, constituindo assim um conjunto de rochas, vegetação e nuvens que permanece em existência paralela à da civilização. Se por um lado La Région Centrale compartilha a polaridade da representação formada pela

${ }^{249}$ Cf. Sitney, "Michael Snow's Cinema", in The Essential Cinema (Nova York: Anthology Film Archives, 1975), p. 223. 
lentidão (que nos permite ver o espaço focado em seus mínimos detalhes) e a velocidade extrema (que abstrai suas formas), por outro lado não existe qualquer interação aparente entre os movimentos e o que eles descrevem, o que é reforçado pelo caráter mecânico da grua. Qualquer encontro aparente entre a câmera e o espaço deve necessariamente ser o resultado de uma conjunção mais ampla que a casualidade e arbitrariedade de Back and Forth. Nos termos de Bazin, Back and Forth flerta ora com o potencial teatral da cena cinematográfica, ora com o anti-antropocentrismo potencial do cinema, enquanto La Région Centrale se entrega completamente ao anti-antropocentrismo.

Uma terceira diferença é a duração dos dois filmes: Back and Forth dura aproximadamente 50 minutos, enquanto La Région Centrale dura cerca de 180 minutos. A amplitude do espaço se reflete na amplitude temporal abarcada pelo filme, que atravessa diferentes períodos do dia. Assim como a velocidade da câmera, são esses estados que definem o que é visto: a luz solar às vezes esculpe a paisagem com sombras bem delineadas, mas às vezes o céu coberto de nuvens cria uma atmosfera difusa que achata os aspectos mais distantes. À noite, apenas a lua é visualizada, como um objeto brilhante numa paisagem escura - e como não temos outras referências, é como se o ponto luminoso surgisse e desaparecesse rapidamente da tela. Sitney descreve a progressão dessas etapas:

\footnotetext{
Entre uma abertura extremamente lenta - em que espirais se afastam gradualmente do solo rochoso diretamente abaixo dos limites do horizonte, como se sentindo a área da paisagem acessível à exploração da câmera - e um final acelerado - em que a paisagem passa como se vista por um satélite girando no espaço - há seções dedicadas à aurora, ao crepúsculo, ao movimento da lua à noite, explorações telescópicas do horizonte, estudos detalhados do terreno próximo da câmera, afirmações da gravidade e perspectivas sem um local fixo de referência. ${ }^{250}$
}

O quadro isola uma parcela do espaço ao mesmo tempo em que afirma o que se encontra além dele. O quadro "enfatiza a continuidade cósmica que", segundo Snow, "é bela, mas trágica: ela continua sem nossa presença". ${ }^{251}$ Há aqui uma curiosa semelhança

\footnotetext{
${ }^{250}$ Ibid., p. 226.

251 "Michael Snow on 'La Région Centrale", in Film Culture, n' 52, primavera de 1971, p. 63.
} 
com as preferências de Bazin, na afirmação da extensão espacial para além da câmera e no registro contínuo desse espaço.

Wavelength (1967) é o primeiro filme de Snow que aborda a apreensão do espaço, e também o exemplo quintessencial, tanto em sua trajetória como em seu impacto na vanguarda americana. O próprio Snow descreve o filme como um zoom contínuo que dura 45 minutos e que vai de um plano aberto de um apartamento até um close em uma de suas paredes. A sala e o zoom são interrompidos por quatro eventos humanos, incluindo uma morte. O som nessas ocasiões é sincronizado, com música e diálogo, mas a partir do primeiro evento surge outro elemento sonoro, uma onda senoidal em crescendo que permanece até o final. Uma descrição mais estrita da obra não a colocaria como um zoom contínuo, mas uma série de planos ordenados de modo a sugerir uma continuidade entre eles, já que os cortes são perceptíveis. Os planos possuem durações diferentes, mas a velocidade e escala do zoom permanecem as mesmas, constantes como o crescendo da onda senoidal.

Os quatro eventos aos quais Snow se refere são, em ordem de aparição: (1) uma mulher supervisiona a arrumação de uma estante carregada por dois homens, e depois os três deixam a sala; (2) a mesma mulher retorna com uma amiga, ambas ouvem uma música no rádio e as duas deixam a sala; (3) um homem entra no lugar e cai no chão, permanecendo imóvel; (4) a primeira mulher retorna, encontra o homem caído, liga para alguém avisando que há um corpo no apartamento, e deixa a sala mais uma vez. Como o zoom prossegue independente dos eventos, nossa visão é cada vez mais restrita, a ponto de o quarto evento ser apreendido já com a câmera enquadrando a mulher acima de sua cintura. O término do zoom coincide com o enquadramento de uma fotografia do mar na parede do apartamento.

O filme dura 45 minutos; caso fosse composto por um único plano, a relação temporal entre os eventos seria absolutamente contínua, análoga à temporalidade que experimentamos durante a projeção; a gradual concentração do campo de visão estaria sob uma mesma medida, e o filme teria uma ligação considerável com o realismo como defendido por Bazin. Mas a estratégia de Snow é outra: o movimento do zoom aparenta uma continuidade, chega mesmo a construí-la, mas as mudanças no registro são perceptíveis, desde cortes para uma tela preta, para blocos de diferentes cores, e mesmo para diferentes horas do dia. 
Snow se diz interessado no equilíbrio entre a ilusão de um espaço em profundidade e os "fatos de luz" na superfície do filme, e menciona esse equilíbrio na pintura como a relação entre a tinta e as formas que essa tinta assume na tela, fazendo com que vejamos ao mesmo tempo algo em si e a representação de outra coisa. ${ }^{252} \mathrm{O}$ que Frampton parecia exaltar em Weston, a identificação do pretexto fotográfico com a superfície material da impressão, e o que Bazin parecia exaltar na "transparência" fotográfica, a imagem como "um nada que revela algo", servem como os dois termos entre os quais Snow busca se situar.

Em Wavelength, há uma sala, e há um filme sobre a sala, duas entidades que parecem interagir - a tela se revela por vezes transparente, como uma janela através da qual observamos um espaço em profundidade, mas em outros momentos se revela opaca, como uma superfície sobre a qual vemos formas cromáticas. Podemos estender esse equilíbrio para a temporalidade que resulta do movimento contínuo e a temporalidade que resulta das intervenções sobre essa continuidade. Há alguma continuidade, sugerida pela permanência do apartamento, de sua unidade espacial e a progressão do zoom em uma mesma direção; há também uma série de interferências que reforçam a articulação, a ressignificação do movimento através das características do espaço. Em diferentes momentos há uma sobreposição de imagens sobre o zoom: em uma delas, a sobreposição revela uma imagem vista anteriormente, uma etapa anterior do movimento, enquanto outra apresenta uma imagem que veremos apenas mais à frente.

Sobre suas intenções com o filme, Snow diz que buscava realizar "uma declaração definitiva de espaço e tempo puramente fílmicos". Ao tratar o movimento do zoom, sinônimo da duração do filme, como um espectro, uma linha que efetua a ligação entre dois pontos, a composição de Snow se torna uma espécie de modulação dessa linha. Compor sobre esta linha é a operação de estabelecer os pontos nos quais ela terá sua causalidade reforçada (sugerida pela ordem dos "eventos humanos" com som e imagem sincronizados), os pontos nos quais as disposições à "memória e profecia" serão enfatizadas (as imagens sobrepostas, retomando eventos anteriores ou projetando eventos posteriores), e os pontos nos quais a própria continuidade do movimento e a unidade do espaço serão questionadas (os blocos cromáticos que interrompem a visão do apartamento).

${ }^{252}$ Cf. Michelson, “About Snow”, in October, no 8, primavera de 1979, pp. 111-112. 
É neste sentido que Michelson argumenta que Snow redefine o espaço fílmico como aquele da ação. Mas não a ação física visualizada sobre a tela e reconhecida como análoga a ações numa realidade à parte: ao igualar os fatos na superfície fílmica com os fatos visualizados no espaço em perspectiva, assim como a disposição diacrônica e sincrônica desses eventos através do zoom, Wavelength identificaria o traçado espaçotemporal com um movimento da consciência. Um movimento que tem um destino, um ponto de chegada, do qual decorre uma expectativa:

procedemos da incerteza à certeza, enquanto a câmera reduz seu campo, instigando e então resolvendo a tensão de nosso deslumbramento até seu destino final, descrevendo, na pureza esplêndida de seu único, lento movimento, a noção de "horizonte" tão característica de todo processo subjetivo e fundamental como um traço de intencionalidade. ${ }^{253}$

Em One Second in Montreal (1969), Snow apresenta uma série de fotografias de espaços considerados para a construção de um monumento. O filme é silencioso; vemos apenas as fotografias, uma de cada vez, por toda a extensão da tela. Diferente de Nostalgia, aqui não há um processo físico que toma conta dos objetos registrados e que inclui uma dinamização no caráter estático das imagens: as fotografias permanecem estáticas, e não há qualquer interferência no registro enquanto elas são visualizadas. A única dinâmica envolvida é a granulação própria da filmagem, o que reforça ainda mais a sensação de duração sendo imposta a imagens imóveis. A duração de cada plano é aumentada gradativamente, até chegar ao meio da obra, a partir do qual a duração diminui gradativamente. O filme se torna então a disposição de "seções de tempo", a definição de um espaço superficial em que reconhecemos as referências, talvez mesmo o contexto, mas em que não há movimento, não há passagem senão a ordem e o corte arbitrários.

So Is This (1983) é constituído inteiramente por palavras, dispostas em quadros separados e organizadas de modo a formar frases apresentadas em diversos padrões rítmicos. Em resumo, uma série de cartelas, todas elas centralizadas e nas quais a extensão da palavra determina o tamanho de sua fonte: quanto mais curta a palavra, maior é a fonte, e quanto mais longa, menor a fonte. A mesma articulação de seções

${ }^{253}$ Michelson, "Toward Snow", in Sitney, The Avant-Garde Film, p. 174. 
temporais de One Second in Montreal retorna (também em silêncio), mas aqui sem qualquer referencial fotográfico que não o traçado gráfico das palavras - o que em Zorns Lemma era o conflito entre o caráter fotográfico e o caráter verbal, entre o que era concreto e o que era abstrato em cada imagem, aqui é apenas abstração verbal. A própria linearidade que Frampton identificava com a lógica verbal é a linha-mestra do filme de Snow: So Is This é inteiramente dependente da capacidade do espectador de compreender as conexões entre as diferentes cartelas, de memorizar os conteúdos referidos por elas, e a complexa construção de camadas que opera na repetição das mesmas cartelas, em suas diferentes combinações. A narrativa se torna a manutenção de um direcionamento intelectual, a condução do pensamento através das medidas e referências linguísticas. ${ }^{254}$

Em Rameau's Nephew (1974), a exploração da linguagem se dá através das relações entre som e imagem, especialmente pela linguagem falada. Cada sequência do filme aborda uma possibilidade dessa interação, indo desde a sincronia até os mais variados tipos de assincronia. Snow compara a composição à estrutura de um livro, dividido em capítulos, que por sua vez são divididos em parágrafos, que são divididos em frases, divididas em palavras - ele se diz interessado na maneira como damos sentido ao encadeamento cumulativo de elementos. ${ }^{255}$

Uma das sequências apresenta um plano próximo das mãos de Snow sobre uma pia, ao que ele começa a bater com as mãos sobre as superfícies, como num improviso puramente percussivo. Esta é uma sequência em que o som está em sincronia com a imagem, portanto ouvimos os sons enquanto estes são gerados por cada um dos gestos, pelo contato entre as mãos e os materiais. ${ }^{256}$ Outra sequência mostra um homem declamando um texto que foi completamente desmembrado para que a sonoridade das palavras se tornasse ininteligível; a cada conjunto de sons declamado, vemos uma interferência cromática na superfície do plano, como um reforço rítmico da estrutura do discurso. Em outra seção, uma cena é exibida de trás para frente, de modo que os sons parecem surgir repentinamente e finalmente se esconder na boca de cada um dos participantes, enquanto um lento zoom revela o espaço da sala.

\footnotetext{
${ }^{254}$ Cf. Scott MacDonald, "So Is This", in Film Quarterly, vol. 34, no 1, outono de 1985, p. 85.

${ }^{255}$ Ver a entrevista de Snow a Robert Gardner, no programa Screening Room (1977).

${ }^{256}$ Em inglês, a expressão sync sound se refere ao som apresentado em sincronia com a imagem. $\mathrm{O}$ fato de a cena ter uma ação sobre uma pia (sink) é um exemplo do interesse de Snow por todas as relações possíveis entre a linguagem e os elementos do filme, desde trocadilhos até confusões entre o som e o sentido, entre os nomes e os objetos, ou entre o som e a imagem.
} 
Rameau's Nephew é de certa forma um catálogo de possibilidades, uma construção enciclopédica, com alguns temas e motivos recorrentes de maneira extremamente vaga e alusiva (em sua descrição na entrevista a Robert Gardner, Snow diz que a água é um dos "temas", o único elemento que não permanece preso aos interiores nos quais as pessoas se encontram, que surge da natureza, dos espaços abertos, e atravessa a civilização). O bloco de realidade, a imagem em sincronia com o som, apresentado de maneira íntegra e unívoca, é apenas uma dessas possibilidades. Ao redor dela, vemos atrasos e deslocamentos entre som e imagem, dissociações de sentido e qualidade, a exploração de trocadilhos, confusões sensoriais e a dualidade entre a percepção de um evento concreto e um desvio deste para a abstração formal.

Frampton se dizia interessado na concepção do filme como algo nãodeterminado pela cultura, algo que pudesse ter uma autonomia nesse sentido. A linguagem parece ser um entrave nesse processo, o que talvez nos faça compreender melhor a negação feita por Brakhage à "geometria do pensamento". Em Rameau's Nephew, Snow mergulha justamente nesta problemática. A dependência das especificidades do idioma é completa, um fato reconhecido pelo próprio Snow, que incluiu como subtítulo do filme "For English-speaking audiences" ("Para falantes da língua inglesa"). Há um radicalismo formal evidente no tratamento combinatório dos elementos - nos fotogramas e sílabas tratados como unidades, na reverberação do som sobre a imagem e vice-versa -, mas as diferentes dimensões só parecem possuir um sentido (ou ao menos revelar um sentido em toda a sua complexidade) enquanto há um mínimo denominador comum na forma da linguagem. ${ }^{257} \mathrm{Se}$ em Bazin o foco na psicologia coexistia com a aceitação da realidade social externa à obra, aqui o foco na investigação epistemológica coexiste com a aceitação de outra realidade social exterior: não mais a realidade visível, objetivamente representada pela fotografia, mas o sistema linguístico como um todo.

\section{A ordem dos fotogramas}

Assim como Frampton, Peter Kubelka defende que o cinema não é definido pelo movimento, mas pela projeção de imagens estáticas num ritmo muito rápido. A ilusão

${ }^{257}$ Cf. Snow, "Notes for Rameau's Nephew", in October, nº 4, outono de 1977, pp. 43-50. 
de movimento é uma possibilidade, não uma necessidade. Ele define o cinema como a projeção de impulsos de luz, e a modulação desses impulsos através dos fotogramas sua coordenação no espaço da tela. A novidade do cinema para Kubelka, como para Brakhage, é a de ser uma arte que "dá à luz uma dimensão no tempo", através de sua conservação e ordenação na faixa de filme. Frampton e Sharits, como vimos, comentam a composição de um filme como a construção de uma notação a ser "lida" pelo projetor; Kubelka reforça, em sua elaboração sobre o cinema "métrico", que é possível ainda haver um roteiro, um projeto anterior que estabelece a organização dos elementos através de medidas, como numa partitura, desprovida de notas ou de uma escala, mas constituída por "seções de tempo". 258

O que se torna evidente nos textos de Kubelka é que seu argumento é contrário à concepção de que a fotografia tem seu valor no fato de apresentar a realidade. Mas esse argumento não é direcionado simplesmente à fotografia, e sim às artes em geral. Ele diz que, quando uma arte está apenas refletindo a realidade, ela não possui valor, pois não pode ser articulada - a articulação é para ele o objetivo da arte, a representação de um ponto de vista. A natureza "objetiva", nesse caso, é vista como disforme, ou completamente aberta; para que haja precisão, ela deve ser interpretada e trabalhada pelo artista. Kubelka considera a imagem fotográfica na mesma chave de Arnheim e Vertov, algo cuja "imediatez" deve ser superada. A realidade é considerada como extremamente complexa, como o era por Bazin, mas aqui a solução é invertida: ao tentar reproduzir essa realidade, o cinema se revelaria um tanto inferior ao seu objeto, um substituto pobre, em que há somente perda de qualidades. A batalha entre "meio de expressão e realidade", para Kubelka, deve pender para o primeiro lado, pois é apenas através do reconhecimento da subjetividade na interpretação, e do desenvolvimento de um método, de uma linguagem própria à expressão dessa subjetividade, é que a arte seria elevada. A arte não é vista como uma imitação da realidade, mas uma articulação ao redor da realidade. ${ }^{259}$

Kubelka se pergunta como se daria a articulação no cinema. Ele cita Eisenstein, que defendia a articulação na colisão entre planos, mas logo apresenta o motivo de sua discordância: o plano para Kubelka não é a menor unidade possível, e sim o fotograma, que é o mínimo de luz que se pode "modular" na projeção de um filme. O fotograma

\footnotetext{
${ }^{258}$ Cf. Carlos Adriano e Bernardo Vorobow, Peter Kubelka: A Essência do Cinema (São Paulo: Babushka, 2002), pp. 19-23.

${ }^{259}$ Ibid., pp. 23-24
} 
deve então ser considerado o elemento básico, o fundamento da articulação. ${ }^{260} \mathrm{O}$ desenvolvimento de seu cinema métrico se dá na busca pelas maneiras possíveis de articular os fotogramas, tendo em mente leis gerais que estabeleçam ordem e sentido às suas propriedades.

O primeiro filme de Kubelka que demonstra claramente suas preocupações estruturais é Adebar (1957). Ele diz que, vendo os filmes narrativos comerciais, se tornou completamente insatisfeito com a ausência do que chamou de uma "forma satisfatória". Kubelka diz ter conhecido os templos gregos, a arquitetura renascentista, e ter estudado a música erudita ocidental - todos baseados numa forma e estrutura rítmica claras. O cinema narrativo para Kubelka é como a natureza simplesmente entregue pela fotografia: amorfo, com um tempo sem medidas claras. É essa necessidade rítmica que ele diz ser fundamental na criação artística, na dependência harmônica dos elementos. A visão do fotograma como a unidade básica leva ao reconhecimento de um ritmo inerente no cinema, uma medida elementar já em sua aparência, os 24 fotogramas por segundo. Assim como a escala musical "reduz todas as possibilidades sonoras a doze intervalos", Kubelka decide efetuar em Adebar uma redução de seus elementos a um número específico, dos quais ele articula seu movimento e sua forma (os detalhes internos da imagem não o interessam neste ponto, o que é um dado importante). ${ }^{261}$

Adebar é composto por registros de pessoas dançando. As imagens têm seu contraste elevado, de modo que vemos apenas suas silhuetas sobre um espaço neutro. Sitney descreve a estrutura da composição:

O início e o final de cada movimento é uma imagem estática. Cada corte passa de uma imagem positiva para uma negativa ou vice-versa. Assim, uma imagem estática positiva se torna um movimento negativo que se torna um movimento positivo... Existem 16 planos diferentes, quatro movimentos diferentes, neste filme de um minuto e meio. Cada movimento é repetido pelo menos uma vez, mas nada acontece como antes. Uma comparação pode ser feita com as estruturas musicais de Anton Webern. ${ }^{262}$

\footnotetext{
${ }^{260}$ Kubelka, "The Theory of Metrical Film", in Sitney, The Avant-Garde Film, op. cit., pp. 140-141.

261 Ibid., pp. 144-148.

262 Sitney, "Kubelka Concrete", in Film Culture, no 34, outono de 1964, p. 49.
} 
Webern se refere às variações como uma maneira de alcançar maior unidade na composição, através da repetição de uma mesma ideia em todas as suas formas possíveis. ${ }^{263}$ Os modos retrógrado e invertido na música são análogos às inversões de cores, direções e movimentos de Kubelka, e o que essas inversões descrevem é o próprio princípio de ordem desejado por ele. Como no filme de Richter, vemos blocos de cores se movendo sobre a tela, mas desta vez eles possuem formas mais ou menos reconhecíveis. Vemos homens e mulheres dançando, e sabemos que se trata de uma situação análoga à música que ouvimos (uma melodia curta, repetida por toda a duração do filme). Mas Kubelka nos apresenta apenas seus contornos, e rebate todas as ações com seu inverso, seja em escala, em cor, em direção, ou em movimento. O término do filme coincide com o final das variações: não há qualquer progressão ou desenvolvimento. Se cada um dos planos, cada uma das ações reconhecíveis e bem definidas for considerada como uma linha reta, o conjunto de linhas e as ligações entre elas traçam, em suas angulações regulares, uma figura tridimensional, o esqueleto de um sólido.

Seu segundo filme métrico é Schwechater (1958), que dura apenas um minuto. Kubelka comenta diversas vezes o contexto em que o filme surgiu, através da encomenda para um comercial de cerveja em que ele foi obrigado a filmar determinadas cenas. O que era de seu interesse, novamente, não era o conteúdo das imagens - que ele diz ser praticamente zero - mas a "energia visual" que ele criaria a partir do material. Kubelka diz que a composição de Schwechater foi baseada no que ele percebeu como sendo a estrutura de alguns eventos naturais. ${ }^{264} \mathrm{Um}$ exemplo seria um riacho: ao observarmos um riacho, vemos bolhas, feixes de luz, formas que surgem e nunca mais retornam; a mudança é a única constante. É através dessas mudanças que seríamos capazes de "sonhar", de ver algo a partir dessas formas. Outro exemplo seriam as nuvens: vemos uma nuvem se parecer com um cavalo, mas ela logo se altera e passa a se parecer com uma árvore, e depois com um castelo. Outros exemplos, como uma chama ou o vento que balança uma árvore, mostram como sempre ocorrem mudanças, mas essas mudanças são estruturadas de maneira exata. O riacho é regido por leis; quando uma bolha surge e desaparece, existem fatores envolvidos, como a velocidade da água, o leito do riacho, o vento, etc. Foram esses princípios que Kubelka diz ter

\footnotetext{
${ }^{263}$ Cf. Webern, "The Path to Twelve-Tone Composition", in Willi Reich (ed.), The Path to the New

Music (Pennsylvania: Theodore Presser, 1963), p. 53.

${ }^{264}$ Ibid., pp. 149-150.
} 
incluído em Schwechater, concentrando-se completamente nas regras que serviriam para estruturar o material:

Eu tive como material básico um filme de dois minutos. Então eu o dispersei em vários elementos. Um minuto era a duração que eles queriam. Isto é exatamente 1440 fotogramas. Havia dois sons, um alto e um baixo. Na faixa sonora pode-se ver dois tipos de ondas exatamente regulares, senoidais. A regra geral é a alternância de imagem e não-imagem: um fotograma preto, um fotograma com imagem; dois fotogramas pretos, dois fotogramas com imagem; quatro fotogramas pretos, quatro fotogramas com imagem, etc.; um-um, dois-dois, quatro-quatro, oito-oito, dezesseis-dezesseis, trinta e dois-trinta e dois, etc. Quando se tem trinta e dois pretos, há um ponto de descanso. ${ }^{265}$

Podemos perceber nesses dois filmes a importância elevada que Kubelka dá ao controle temporal do material, em detrimento de seu conteúdo visual interno. O plano coordena necessariamente informações visuais em continuidade, ainda que vagas e dispersas; a escolha do fotograma como unidade básica faz com que Kubelka dê prioridade às coordenadas rítmicas, "duracionais", e como elas interferem ou conduzem as mínimas propriedades visuais restantes.

Um caso mais extremo é Arnulf Rainer (1960), seu filme seguinte, composto a partir de quatro faixas - uma com filme completamente transparente (de modo que vemos a tela branca na projeção), outra com filme completamente preto; e duas faixas de som, uma sem qualquer som e outra com som contínuo, com o que é chamado de "ruído branco", com todas as frequências sonoras, de modo que o silêncio e o ruído são paralelos aos fotogramas brancos e pretos. Da mesma forma que nos filmes anteriores, Kubelka descreve a composição como uma busca por harmonia, comparando-a com a música, em que os diferentes intervalos entre as notas levam a diferentes experiências. Mas um ponto é enfatizado por ele: essas experiências já se encontram no material, como potencialidades. $\mathrm{O}$ artista deve simplesmente descobri-las. ${ }^{266}$

\footnotetext{
265 Ibid., p. 154.

266 Ao comentar os estudos de Louis-Bertrand Castel sobre as relações entre cores e sons, Claude LéviStrauss aponta que "se o branco resulta da mistura de todas as cores, o preto as contém em potencial, é de certo modo seu gerador", e cita uma frase de Castel, para quem "tudo vem do preto para perder-se no branco". O filme de Kubelka lida com as duas polaridades fundamentais do cinema, tanto no som como na imagem; entre o fotograma preto e o fotograma branco encontram-se todas as imagens potenciais, como todos os sons potenciais encontram-se entre o silêncio e o ruído branco. Cf. "As
} 
A composição de Arnulf Rainer passa então por um período em que Kubelka diz "saborear" os diferentes elementos possíveis, isto é, as diferentes combinações entre as quatro faixas. Uma possibilidade seria a alternância entre um fotograma preto e um fotograma branco, o que seria o elemento "mais forte", com maior contraste e tensão; mas também são possíveis combinações de dois fotogramas pretos e dois brancos, três pretos e dois brancos, etc. Existem, então, dois limites, um máximo (a alternância constante entre preto e branco, ruído e silêncio) e um mínimo de intensidade (o que seria uma série contínua de fotogramas negros e silêncio). As mesmas possibilidades se encontram na relação entre som e imagem: pode-se repetir durante alguns segundos os fotogramas pretos em silêncio, enquanto o ruído e o silêncio se alternam rapidamente; também se pode alternar rapidamente os fotogramas preto e branco enquanto o som se alterna de acordo com outro padrão.

A obsessão de Kubelka pela medida exata, pelo controle das durações, é levada em Arnulf Rainer ao seu ápice. A estrutura do filme é baseada em uma notação, uma ordenação de seus elementos de modo que "cada termo na série, junto com sua posição e duração, possa ser perfeita e inteiramente determinado". As recorrentes analogias musicais de Kubelka são adequadas; as linhas de imagem e som são conduzidas paralelamente, como dois instrumentos, seus padrões rítmicos ora convergindo em uma monodia, ora dialogando em um contraponto, ora seguindo direções opostas. É esta redução e simplificação que permite que Kubelka se refira a cada uma das "frases" utilizadas de acordo com seus "resultados", do reconhecimento de sensações básicas. A descrição do filme como uma "curva abstrata" se torna mais clara: ao catalogar essas sensações através de seus correlatos materiais, Kubelka pode então ordená-las para que a projeção da obra constitua a ordenação de sensações desejada.

A progressão dos três filmes métricos de Kubelka também é evidente. Adebar renuncia à representação cinematográfica tradicional, baseada na integração dos aspectos sensíveis por um princípio realista contínuo; Schwechater renuncia à ilusão de movimento, através de sua fragmentação e interrupção ao nível do fotograma; Arnulf Rainer renuncia completamente à imagem, colocando o espectador frente a uma espécie de grade sobre o processo contínuo da projeção. ${ }^{267}$ Esta progressão é também, como

palavras e a música", in Lévi-Strauss, Olhar Escutar Ler (São Paulo: Companhia das Letras, 1997), pp. 99-100.

${ }^{267}$ Cf. Carlos Adriano, Peter Kubelka: A Essência do Cinema, op. cit., p. 22. No documentário de Martina Kudláček, Fragments of Kubelka (2012), o cineasta é mostrado em uma projeção de Arnulf 
vimos na descrição de Sitney para as etapas da vanguarda americana, a ênfase gradual no quadro como uma unidade autônoma, desligada da realidade externa.

Mas no filme seguinte há uma espécie de retorno, um redirecionamento dessas mesmas preocupações. Em Unsere Afrikareise (1966), Kubelka se viu novamente com um filme de encomenda, desta vez o registro de uma viagem à África feita por comerciantes austríacos. E assim como em Schwechater, a encomenda serviu apenas como o ponto de partida para que o material fosse gerado, e posteriormente, à parte das intenções iniciais, Kubelka pudesse organizar sua composição. Se nos filmes anteriores o interesse pela imagem era nulo, em Afrikareise há uma aceitação da imagem, mesmo a imagem contínua, realista, em movimento, como um elemento a ser articulado. ${ }^{268}$

O método utilizado por ele para se familiarizar com o material é descrito por Sitney:

De dez horas de fita de som que ele gravou com um microfone escondido durante a expedição - às vezes enquanto filmava e às vezes não -, ele selecionou uma hora e meia que transferiu para uma faixa de filme. Ele escreveu os noventa minutos, incluindo os ruídos de fundo, músicas, rugidos, em um livro imenso. Então ele memorizou o livro. ${ }^{269}$

Com a imagem, um procedimento semelhante: uma cópia em preto-e-branco do material bruto foi gerada; os primeiros fotogramas de cada plano foram então cortados e pendurados como fitas em um tipo de cartaz, para que Kubelka pudesse se referir imediatamente a cada um deles. Deste modo, ele teve diante de si um arquivo, como o vocabulário de um poeta. E assim como o poeta deve ter em sua memória o conjunto de palavras e expressões que formam a linguagem da qual fará uso, Kubelka tratou suas imagens e sons como pontos aos quais poderia recorrer. Mas se o conjunto de elementos de Arnulf Rainer, por sua completa negação da imagem, não se refere a uma realidade

Rainer, enquanto diz que o filme para ele é como uma estrutura em que ele pode "entrar", ou "se deitar".

268 John Pruitt comenta que essa mesma progressão é encontrada na obra de Robert Breer, conhecido por seu trabalho com animação e seu interesse na composição ao nível do fotograma. A passagem de Arnulf Rainer a Unsere Afrikareise seria análoga à passagem de Breer de 70 (1970) a Fuji (1974). Ver "Stan Brakhage and the Long Reach of Maya Deren's Poetics of Film", in Steinhoff, Op. cit., pp. 118119.

${ }^{269}$ Sitney, “Kubelka Concrete”, Op. cit., pp. 50-51. 
externa, Afrikareise afirma essa realidade na medida em que tanto suas imagens como sons se referem ao mesmo contexto, reconhecido visual e auditivamente.

Ele comenta uma ocasião que presenciou na África, em que as pessoas de um vilarejo estavam reunidas numa planície para um evento que envolvia uma série de danças. Quando a tarde chegou ao fim, todos pararam para observar o pôr do sol. Enquanto o sol se aproximava do horizonte, todos estavam estáticos, em silêncio, até o momento em que o sol tocou o horizonte, ao que o chefe do lugar bateu pela primeira vez em seu instrumento de percussão. Kubelka descreve esse como um momento de êxtase, algo que lhe pareceu tão antigo quanto a própria humanidade, representado diretamente pelo encontro entre luz e som. ${ }^{270}$

No cinema, então, o encontro entre os dois sentidos, entre o olho e o ouvido, tem uma importância fundamental. Na natureza nenhum trovão pode ocorrer sem um raio, e nenhum raio sem um trovão, mas Kubelka lembra que no cinema podemos separá-los. Dessa forma, se o filme tiver ao mesmo tempo som e imagem, deve levar em conta essas relações. É a partir desse raciocínio que Kubelka defende o que chama de "montagem metafórica". A confirmação do som pela imagem, ou da imagem pelo som, é uma possibilidade, a sincronia natural; em Afrikareise ele lida com ela pontualmente, mas também com outras possibilidades, como a imagem que se relaciona com um som imediatamente posterior, ou o som que se relaciona com uma imagem de outra maneira que não por uma confirmação mútua - por negação, ironia, etc. Uma imagem deve necessariamente ser pensada em sua relação com as imagens anterior e posterior, com o som anterior e posterior; o mesmo é válido para o som, pois ambos são tratados com a mesma importância.

Essas exigências fazem com que o filme, apesar de sugerir certas situações, nos apresentar a pessoas que retornam em diversos momentos, e apesar de ter inscrita em seu próprio título a localização e a razão das ações, seja extremamente resistente a uma apreensão narrativa, ou mesmo a uma compreensão linear dos eventos. As diferentes combinações de elementos, em diferentes pontos do filme, resultam em efeitos e sentidos variados. Se há uma curva abstrata aqui, como em Arnulf Rainer, ela parece mais ambígua justamente por resultar de uma reordenação da realidade. Apesar das diferenças, há uma semelhança com a estrutura de Adebar, e em mais de uma ocasião o

${ }^{270}$ Cf. Kubelka, "The Theory of Metrical Film”, in Sitney, Op. cit., p. 158. 
filme foi descrito como tendo uma forma "cristalina". ${ }^{271}$ Mas uma diferença crucial entre Kubelka e os cineastas estruturais é que, em seus filmes, a forma não é aparente de imediato. A complexidade de suas operações, e a imensa quantidade de regras autoimpostas faz com que sejam percebidos superficialmente como manifestações de uma estranha desordem que após repetidas análises se revela tudo menos caótica. Este é mais um ponto que aproxima Kubelka de Webern, a preferência por uma progressão irregular, mas ordenada. Em Adebar e Schwechater a aspiração serial é clara: os mesmos eventos se repetem, mas, como enfatizado por Sitney, nunca da mesma forma; eles funcionam como variações em que o tema central é a série formal que estabelece suas proporções.

${ }^{271}$ No documentário já citado, Kubelka analisa trechos do filme na moviola, revendo e comentando várias vezes os mesmos momentos, demonstrando a riqueza contida em cada segundo de filme. Em entrevista a Peter Gidal, Frampton diz que a densidade do filme de Kubelka é tamanha, e que tanta paciência parece ter sido dedicada à sua composição, que ele espera poder ver o filme "a cada três meses pelo resto da vida". Ver "Interview with Hollis Frampton", in October, $\mathrm{n}^{\mathbf{0}} 32$, primavera de 1985, p. 117. 


\section{Meridianos}

$\mathrm{Na}$ seção final do primeiro capítulo foi proposta a metáfora do globo como uma descrição das relações entre os ideais de Bazin e Frampton, representados pelos dois pólos. O afastamento das especulações essencialistas em direção às análises críticas se deu necessariamente como uma aceitação da polaridade inicial e o confronto com as condições históricas. $\mathrm{O}$ objetivo da imagem do globo foi o de estabelecer um campo a ser descrito; diferentes áreas a serem reconhecidas a partir do eixo polar, ao redor do qual retornam constantemente algumas características comuns. No decorrer dos capítulos seguintes foi apresentada uma investigação dessas características. A recorrência de algumas questões permitiu que as comparações entre os dois hemisférios fossem realizadas de modo que as diferenças e semelhanças se tornaram mais claras.

Esta seção propõe um breve mapeamento do que poderíamos chamar de algumas regiões ao redor dos pólos. A trajetória em direção às linhas centrais do globo pode ser feita de diferentes maneiras; a evidência disto está na multiplicidade de caminhos citados, com acréscimos que revelam as gradações na divisão inicial. Temos, portanto, a possibilidade de comparar não apenas as duas vertentes gerais, mas as ramificações internas de cada uma delas - uma comparação que represente as consonâncias e dissonâncias particulares de cada hemisfério. A partir disso, surge ainda a possibilidade de uma nova comparação entre os dois hemisférios, posterior à descrição dos "meridianos" que cruzam suas diferentes regiões, voltada a uma nova tentativa de visão global.

\section{Diferenças internas}

Os três pontos levantados por Andrew se confirmam nos textos comentados de Rohmer, Rivette, Astruc e Mourlet: os quatro partem da objetividade fotográfica, tal como descrita por Bazin, em sua extensão ao movimento e ao som. O "princípio realista" que podemos considerar como a tendência centrífuga aplicada não apenas ao quadro, mas também à cena e à própria narrativa - está presente de alguma maneira em todos 
eles, ainda que em diferentes níveis. Essas diferenças devem ser apontadas, pois o desdobramento da essência realista como proposta por Bazin não forma uma escala bidimensional, em que cada um dos nomes pode ser disposto de maneira unívoca, mas se aproxima do modelo tridimensional do globo, com a consideração de outras coordenadas. Em resumo, existem diferenças quantitativas, de um maior ou menor número de pontos consonantes, mas também qualitativas, com diferentes modos e acréscimos servindo como pontos dissonantes

Rohmer parece o mais próximo de Bazin tanto na maneira de argumentação como em seu gosto particular e nos tópicos que atraem seu interesse. É nos textos de Rohmer que encontramos algo como uma continuação dos posicionamentos de Bazin, ou de uma extensão de sua postura a tópicos adjacentes. O que Bazin aponta em relação ao quadro ou à cena, por exemplo, Rohmer o faz em relação à cor e ao diálogo. A concepção de uma realidade unificada e organicamente determinada, tendo sua imanência revelada por encontros que resultam de uma interferência mínima, ou ainda de uma abstração que faz transparecer uma simpatia solene entre os elementos da representação sensível, afirmando algo que se encontra além de sua superficialidade estes são pontos importantes tanto para Rohmer como para Bazin. Há uma concordância na visão da realidade como uma entidade com valor espiritual, uma postura quase religiosa em relação a ela, o que Rohmer manifesta mais claramente em seu reconhecimento da presença divina em Stromboli. ${ }^{272}$ Em Minha Noite Com Ela, essa visão surge nas próprias discussões entre os personagens, e é questionada pelo narrador como um jogo entre acaso e predestinação, ou seja, entre o quão fortuitos são aqueles eventos, e o quanto deles é parte de um plano superior, uma integração necessária. ${ }^{273}$

Nos textos e filmes de Rivette também encontramos algum interesse na abordagem da realidade como um organismo, um todo com uma pulsação particular. Mas enquanto Rohmer parece ver a narrativa como um núcleo que atrai ou conduz os elementos dessa realidade - onde talvez possamos reconhecer seu temperamento literário, em sua insistência na palavra como um veículo dramático -, Rivette se volta mais diretamente para o "arejamento" dessa realidade através da articulação puramente espaço-temporal. Essa articulação não parece ser o meio para a revelação de uma

\footnotetext{
${ }^{272}$ Cf. Rohmer, The Taste for Beauty., pp. 124-127.

273 A crítica de Mourlet sobre o filme de Rohmer enfatiza este ponto. Ver "Rohmer ou La mise en scène du langage", in Sur un art ignoré ou La mise en scène comme langage (Paris: Ramsey, 2008), pp. 260-265.
} 
unidade subjacente, mas parece ser ela própria o fim da mise en scène, como em seus elogios a Preminger. A dialética entre ordem e acaso, entre o controle e o improviso, está presente de maneira mais abstrata na obra de Rivette que na de Rohmer. $O$ Raio Verde (Le Rayon vert, 1986), de Rohmer, converge para um fenômeno que sublima o conflito da protagonista, num encontro entre os movimentos internos, da psicologia da personagem, e os movimentos externos, do sol que desaparece no horizonte, numa cena que em alguns aspectos se assemelha à conclusão de Stromboli. Em Rohmer é possível haver revelações deste tipo, elas são mesmo os temas dos filmes, a substância que resulta ao final do processo. ${ }^{274}$ Nos filmes de Rivette, essa mesma realidade não parece invadir as tramas que são traçadas entre os personagens: estas são perseguidas com um olhar amplo o bastante para que percebamos sua integração aos espaços (seja nos prédios e ruas de Paris ou nas praias e regiões montanhosas), mas há uma opacidade na caracterização e na resolução psicológica, quase uma rarefação do drama.

A narrativa tem uma importância evidente para Astruc como um princípio de organização. O ponto em que ele parece diferir de Rohmer é na importância dada à consciência sobre os elementos, ao que ele chama de expressividade plástica e seus encadeamentos. Astruc comenta como o desenvolvimento do cinema se daria por um afastamento da "tirania do visual", se colocando contra a força bruta dos sentidos, retomando as preocupações de Bazin; mas o grau de controle inevitável, parte da equação entre cineasta e realidade, é consideravelmente elevado quando o estilo passa a seguir uma "ideia". Vemos em suas descrições e na própria composição de seus filmes uma preocupação com a parcela de controle que submete os dados sensíveis a um princípio que reorganiza e ressignifica esses dados sob um novo sentido. Este sentido ainda deve residir na unidade espacial, e ser coordenado através de um ritmo próprio dos eventos representados, mas a mise en scène, identificada com a composição no cinema, se torna a marca de um desígnio consciente, o que sugere uma projeção do autor sobre a realidade, que se torna o meio para a encarnação da ideia. Astruc parece concordar com a descrição de Mitry de que no cinema "a realidade é empregada em sua própria narração". ${ }^{275}$ A imagem nos absolve da necessidade de imaginar os conteúdos,

\footnotetext{
${ }^{274}$ É importante notar que a mesma imagem do sol tocando o horizonte é comentada por Kubelka, mas tendo em vista seus aspectos puramente sensoriais, e é utilizada como referência para uma composição baseada na fragmentação e reorganização da realidade. As duas modalidades se encontram num mesmo evento.

${ }^{275}$ Cf. Mitry, Op. cit., p. 15.
} 
mas exige que imaginemos com eles, e a partir das relações feitas entre eles: a imagem não é o fim, mas o início da composição.

Mourlet concorda com os pressupostos de Bazin, mas é mais categórico ao confrontar os filmes com seus ideais. Os tópicos tratados por Bazin ou mesmo Rohmer, se vistos como entidades particulares, têm lugar no sistema de Mourlet, mas ali também parece estar uma parte do controle almejado por Astruc. $\mathrm{O}$ fator antropocêntrico em Mourlet é a chave para o entendimento de sua distância de Bazin: é o que determina tanto a relação entre o cineasta e o mundo, como entre os personagens e o mundo. As variações microscópicas na natureza que Rohmer buscava atrair só têm lugar em Mourlet quando subordinadas a esse confronto mediado por um centro dramático na figura do ator, que coordena e serve de referência tanto para a câmera (para a manutenção de um olhar "puro", direto, ou seja, que não expresse nada independente do drama) quanto para as ações realizadas na cena. O apreço de Rohmer e Rivette pelo neorrealismo, e que parece estar na base de suas explorações do caráter documental no interior da narrativa, é evitado por Mourlet, assim como o elogio ao expressionismo de Murnau empreendido por Astruc. Nos filmes eleitos por Mourlet, reconhecemos acima de tudo a solidez da construção, a gravidade interna que regula os planos como os corpos em cada cena, que foca a energia dramática em sua absoluta necessidade.

A descrição de Sitney para a trajetória da vanguarda americana tem o cinema estrutural como uma espécie de ponto mais elevado. Há uma concordância com o ideal de Frampton no sentido de que o direcionamento seguido pelos cineastas citados por Sitney se dá no abandono gradativo do realismo, da cena, do personagem e da narrativa, para que o filme possa focar a atenção em sua própria construção. A descrição de Noel Carroll para Serene Velocity é reveladora: o filme opera como um experimento, ou uma máquina de pensamento, e o que ele pensa é sua própria condição, sua materialidade e exploração de categorias propriamente cinematográficas.

A discordância entre Frampton e Brakhage é relacionada ao quanto de "ordem" deve reger a composição dos filmes, e o quanto dessas ordens pode ser baseado em algo estabelecido à parte da experiência do próprio cineasta. Em Frampton, o desejo por essa ordem se reflete na linguagem, mas também em como ele busca ordens não-verbais que incluem procedimentos visuais e sonoros apresentados sistematicamente. A obra de Brakhage é marcada pela renúncia constante a diferentes tipos de ordem, e pelo uso dos materiais visuais como elementos a serem dissolvidos num mesmo fluxo. A tentativa de 
Brakhage é a de mergulhar no caos das aparências e traçar sobre elas um movimento que possa refletir tanto sua interioridade, sua própria experiência, como documentar a riqueza visual com a qual ele se deparou nesse percurso. Há um interesse pela posição do cineasta como a força por trás da câmera, mas também por aquilo que ele observa através dela. A descrição de Sitney para a herança romântica na vanguarda americana em particular na aspiração do filme estrutural de se tornar um objeto que não deseja se referir a algo, e que quer apenas ser - é mais presente em Frampton; em Brakhage, o romantismo toma a forma de um desejo pelo inefável, pela fusão entre consciência e mundo, sendo ambos libertos das amarras lógicas e verbais.

Michael Snow demonstra uma preocupação constante com o espaço contínuo e em profundidade que encontramos em todo o cinema realista. Esse espaço não aparece com frequência na obra de Frampton, especialmente como o próprio objeto de investigação. Ainda assim, Snow e Frampton compartilham um gosto pelos sistemas geradores; a inclusão de ambos na categoria do cinema estrutural é claramente devida à repetição de operações por todo o decorrer de algumas obras, como se o princípio coordenador, o fator que estabelece o lugar e a função de cada uma das partes, permitisse a percepção de uma progressão no decorrer das repetições e variações. Comparemos, por exemplo, o ritmo fixo de um segundo das imagens alfabéticas na segunda seção de Zorns Lemma com as panorâmicas de Back and Forth, ou a exploração das possibilidades em La Région Centrale com o "preenchimento" da mesma seção do filme de Frampton por imagens naturais. Sobre a relação entre a linguagem e o aspecto concreto das imagens e dos sons, Frampton parece mais voltado à manutenção de uma tensão constante entre essas esferas, ou a passagem de uma configuração a outra, enquanto Snow parece mais voltado à exploração das possibilidades de maneira puramente descritiva. O filme de Snow que constrói uma progressão mais clara é Wavelength, baseado na oscilação entre os diferentes registros; os outros filmes comentados parecem manter o mesmo procedimento sem que a estrutura geral desenvolva as tensões, como Frampton faz em Critical Mass, por exemplo.

As exigências de Kubelka coincidem com as descrições teóricas de Frampton, e em algum sentido ele é bastante próximo dos cineastas estruturais, a ponto de Sitney considerá-lo um dos antecessores do gênero, junto com Warhol. Mas a forma em Kubelka nunca é perceptível de imediato; ainda que suas estruturas também sejam 
baseadas em princípios simples, o acúmulo e a insistência na articulação ao nível do fotograma tornam os filmes mais próximos dos processos naturais que ele descreve. Frampton também reconhece o fotograma como unidade elementar, mas explora consideravelmente a continuidade e o espaço fotográfico, o que Kubelka quase sempre rejeita. Kubelka parece representar um dos casos-limite da descrição de Frampton, atravessando os tópicos do cinema estrutural, mas saindo deles de uma maneira diferente daquela de Brakhage: não pela rejeição da ordem, mas por um excesso de ordem que cria a impressão de desordem, como se sob a ordem pudéssemos vislumbrar a desordem, e olhando mais profundamente, encontrar uma nova ordem.

Podemos perceber entre Frampton, Sitney, Brakhage, Snow e Kubelka uma relação semelhante àquela descrita em torno de Bazin: pontos de encontro e diferenciação que não sugerem uma simples escala quantitativa, mas um espaço tridimensional, qualitativo, com a revelação das diferentes faces, combinações e aplicações das mesmas ideias. Se os ideais de Bazin e Frampton são os pólos do globo aqui descrito, os outros autores surgem como continentes que possuem partes mais próximas dos pólos, fazendo fronteiras uns com os outros, e em algumas de suas regiões - em diferentes proporções - se direcionam à linha imaginária que separa os dois hemisférios, onde as preocupações parecem se cruzar.

Para efetuar o cruzamento das duas vertentes, podemos recorrer a pelo menos duas estratégias, reconhecendo semelhanças nas preocupações que levam cada um dos autores a se afastarem dos pontos mais extremos, e observando como uma região intermediária parece se delinear através das diferentes trajetórias. A primeira estratégia seria a busca por algo que, mesmo com as dissonâncias, sugere alguma complementaridade, uma espécie de "igualdade na diferença"; a segunda seria a busca por uma continuidade possível, um terreno comum para as duas vertentes.

\section{Tópicos comuns e semelhanças estruturais}

O problema da expressão do pensamento como descrito por Astruc é um dos pontos de partida para a comparação com a vanguarda americana, sendo numa primeira leitura o tópico mais distante do que Bazin incluía no centro de suas preocupações. Também é o 
que faz com que Astruc se assemelhe a Eisenstein em alguns momentos. Ainda que não siga a montagem dialética, Astruc também reconhece a importância de uma postura sobre os eventos representados, algo que ultrapasse a simples apresentação dos eventos. Mas principalmente nos filmes iniciais de Eisenstein, a estrutura dramática surge de maneira completamente diversa daquela preferida por Astruc, em que a continuidade e a compressão temporal têm um papel importante. O cinema de Astruc não é um cinema de planos breves, pensados como ideogramas; ele utiliza planos contínuos e em profundidade, com uma carga interna própria, baseada na afirmação de um mesmo movimento. A filiação de Astruc ao realismo de Bazin ocorre pela manutenção do espaço e do tempo como categorias integradas (espaço-tempo); as ideias que ele reconhece em seus textos, e que parecem dialogar com seus filmes só poderiam vir a existir através dessa realidade. Seu realismo é narrativo e dramático, ainda que receba uma parcela da expressividade (como ele vê em Murnau) ou mesmo da projeção de estados mentais dos personagens (como ele comenta sobre O Poço e o Pêndulo), dois aspectos que foram criticados em outros contextos tanto por Bazin como por Mourlet.

Comparemos então a posição de Astruc com o que Sitney identifica na gênese da vanguarda americana: a tentativa de representar a consciência por meio de uma representação vagamente narrativa. Vimos que a trajetória descrita por Sitney se afasta gradativamente das características realistas da representação. Os filmes de transe, como Meshes of the Afternoon e Fireworks, utilizam um espaço mais próximo das exigências realistas: os planos, considerados isoladamente, são pontos de vista sobre um espaço claramente determinado, e ainda que a passagem de um plano a outro tornem confusas as referências desses espaços, há alguma continuidade entre as ações.

Fireworks é completamente baseado na caracterização de imagens particulares, no sentido e na plasticidade que elas apresentam. Em vários momentos, vemos personagens que surgem sobre um fundo negro, onde a única orientação é a frontalidade da câmera e do protagonista. Os planos do filme de Anger são como as moléculas narrativas que Sitney descreve em Bresson, mas aqui não há uma reação por acúmulo que termina por elaborar uma totalidade externa a cada imagem: Anger reforça o potencial icônico do quadro, voltando todas as atenções para o que ocorre dentro da tela, e dentro de cada período em que reconhecemos brevemente as relações espaciais entre os personagens e os objetos. 
Meshes of the Afternoon organiza uma relação mais estreita entre os diferentes planos e espaços, com passagens que evocam a continuidade dramática de maneira mais evidente. Cada movimento de câmera no filme de Deren parece indicar uma expressão isolada, seja pelo ponto de vista ou pela relação entre a câmera e a personagem; mas durante esses movimentos, a integridade do espaço não é questionada, permanecendo como o fundo sobre o qual tudo ocorre. Os filmes seguintes de Deren - At Land (1944), A Study in Choreography for Camera (1945), Ritual in Transfigured Time (1946) exploram outras faces dessa dramaturgia, com menos ênfases nos objetos cênicos e mais na própria construção do espaço e do tempo como pontos de virada na narrativa, como nos cortes que atravessam cenários completamente diferentes em At Land e o congelamento dos movimentos em Ritual in Transfigured Time. É a integração desejada por Astruc que permite essas explorações.

Os gêneros seguintes na morfologia de Sitney se afastam desse espaço, e por isso da vertente realista como um todo. O "filme lírico" e o "filme mitopoético", ao se basear justamente na fragmentação em prol de uma expressividade mais livre, rejeitam o caráter compacto e geométrico preferido por Astruc - mais próximo daquele que Mourlet elogia em Lang. O espaço de Dog Star Man inclui a superfície da película, tornando a profundidade e a unidade cênica apenas um elemento em meio a outros, e nesse processo só pode sugerir uma estrutura narrativa a partir de imagens recorrentes, não por relações de causalidade ou encadeamento sintático. O filme estrutural, rejeitando a psicologia e enfatizando a construção, parece também se situar fora do terreno considerado por Astruc. Há algum contato entre Astruc e Deren, entre dois cinemas baseados na unidade da cena, mas que dela privilegiam diferentes fatores.

O fator que ganha importância no cinema de Astruc é a transparência da construção. Tudo deve ocorrer como se as formas traçadas por ela já se encontrassem no mundo, já se encontrassem mesmo em movimento; como se a ideia, a "imagem interna", considerada pelo cineasta, devesse ser refletida ou projetada nos devidos aspectos sensíveis através de um registro planejado. Bazin falava sobre obrigar o ser a tomar partido sem trapacear com os seres e as coisas; Astruc parece acrescentar ao lado subjetivo da equação, colocando a interpretação num degrau mais elevado. Mesmo que o cineasta faça com que a natureza "se entristeça em uníssono" com o personagem, isto deve ocorrer necessariamente pelos eventos registrados, e deve manter uma medida de 
organicidade, de naturalidade. O mecanismo da ficção deve sugerir a complexidade de um organismo.

Tanto Rohmer como Brakhage se colocam contra a presença de qualquer esquema pré-concebido em suas respectivas obras, seja ele um método analítico de decupagem ou um sistema formal como no cinema estrutural. Brakhage se diz interessado em capturar o movimento de sua própria percepção, o que num primeiro momento passa por sua interação direta com o mundo visível, mas que eventualmente se afasta disso e se volta para uma construção puramente fílmica. Nos primeiros filmes, Brakhage partilhava a transparência descrita em Astruc (e que em alguma medida existia mesmo em Maya Deren); sua incursão no filme lírico faz com que sua presença por trás da câmera, ou seja, o fator interpretativo, ganhe mais importância; finalmente, em suas intervenções na superfície da película na tentativa de representar a "visão de olhos fechados", o filme se torna um movimento puramente visual, que apenas eventualmente toca num espaço cênico propriamente dito. Quando Rohmer fala sobre a necessidade de uma síntese, para que a beleza do mundo seja revelada, ele se refere a algo que já se encontra no mundo, algo que não deve ser ofuscado pelas características do material fílmico, portanto não deve seguir algo que não a transparência como entendida por Bazin. Por esta ótica, já existe algo nas próprias coisas que deve ser visto, entendido, e que se comunica por movimentos e sons naturais, animados de seu interior. A narrativa para Rohmer não é uma limitação como é para Brakhage; é uma maneira de conduzir essas qualidades, de estabelecer uma interdependência entre aqueles elementos que o cinema, inevitavelmente, deve restringir no quadro e no tempo dos planos.

Rohmer quer que tudo venha "de dentro" do mundo. Os movimentos, a cor, o som, o diálogo, tudo deve ter uma presença marcante, mas não a ponto de desviar a unidade sob eles. O drama é como a grade sobreposta ao cinema total, um guia pela infinidade do mundo. Brakhage quer justamente chegar ao seu próprio interior através de algo externo: ele não quer o aspecto visual imediato, mas o movimento do olhar pelas cores e formas, pelas diferentes qualidades e ritmos visuais. Tudo isto deve ter uma musicalidade, um aumento e diminuição de densidade, como na curva abstrata que Frampton diz estar no cerne de cada narrativa, como se fosse preciso uma síntese do mundo para que certa experiência pudesse ser recriada no filme. Cores, formas e movimentos adquirem assim o mesmo caráter autônomo que Rohmer comentou em outras ocasiões, mas num contexto diferente. 
Paul Valéry falava sobre como uma arte não-representativa - a música ou a arquitetura - deve procurar referências externas à sua própria constituição, para que organize algum tipo desenvolvimento, para que vá do arbitrário ao necessário. Como no cinema defendido por Bazin, as necessidades dos filmes de Rohmer são parte da "psicologia da narrativa". Os planos enquadram os personagens que se movem em espaços definidos pela narrativa, e todo o diálogo com a natureza ocorre dentro da estrutura dramática. É essa estrutura, ainda que mínima, que faz com que qualquer elemento que passe pelo mundo representado, deva necessariamente ser visto como relacionado ao drama. As necessidades dos filmes de Brakhage não são da mesma ordem: seu afastamento do drama coincide com seu afastamento do espaço em profundidade e da continuidade dos planos, ao que ele propõe uma série de registros fragmentados e sobrepostos.

Quando Rohmer escreve sobre Traité de bave et d'éternité (1951), filme de Isidore Isou, fundador do Letrismo, o que ele reconhece de positivo é a parcela realista envolvida na composição. O filme é constituído por cenas extremamente dispersas, conectadas por algumas poucas pessoas recorrentes, entre elas o próprio Isou. $\mathrm{O}$ procedimento composicional mais evidente é a intervenção direta sobre a película, indo desde riscos e manchas sobre os planos (de modo que ainda vemos as imagens realistas em movimento, mas cobertas por sinais gráficos) até o registro de formas abstratas, que parecem ter sido pintadas na faixa de filme. O que Rohmer vê no filme de Isou é um desejo de retornar às coisas "como elas são". Ele diz haver ali a noção de que, após o questionamento e a destruição das aparências, não haverá mais material substancial para a arte, e dessa forma aquele que se põe a derrubar o realismo se torna o mais dependente dele. Traité não é um filme completamente abstrato como os de Richter e Fischinger, assim como não é um filme "literário" (e Rohmer aqui reconhece que mesmo Cocteau e Buñuel o foram em alguns de seus filmes). Há uma sensibilidade propriamente cinematográfica, que não segue a via da aplicação de conceitos pictóricos e musicais sobre o filme, mas que procura resolver os problemas específicos da forma fílmica. Rohmer diz que o mérito de Isou é o de partir das imagens realistas, ainda que seu objetivo seja atacá-las. Ele elogia acima de tudo os momentos que parecem afirmar com mais veemência a presença dos atores e a naturalidade dos movimentos, desprovidos de uma intenção projetada sobre eles. Menos confiante no poder da imagem realista, Isou não permite que ela se desenvolva inteiramente no decorrer do filme, atacando-a com 
insistência de diferentes maneiras; mas a base fotográfica permanece, e os ataques terminam por ressaltar por contraste justamente o que elas possuem de mais realista. ${ }^{276}$

Da mesma forma, o que Brakhage elogia em Intolerância (Intolerance, D.W. Griffith, 1919) é primeiramente a abstração da luz, a ponto de dizer que uma projeção do filme fora de foco manteria a integridade rítmica e a musicalidade das formas. A narrativa para ele é secundária; os eventos e o contexto histórico, ele argumenta, só se tornam poesia através das maneiras como Griffith os trabalha, os organiza. Brakhage se refere ao filme como um "poema tonal", com a recorrência da imagem-refrão (o plano de Lillian Gish com a criança), as repetições, inversões e escalas de enquadramentos, e a coordenação das diferentes linhas históricas como uma fuga temática. ${ }^{277}$ Nos dois casos, há um reconhecimento de que, numa obra em que há a interação, mesmo desequilibrada, entre as duas vertentes, suas características básicas podem ser articuladas e inclusive afirmadas.

Snow é um dos poucos cineastas da vanguarda americana que demonstra um interesse claro pelo espaço em profundidade e pelos planos contínuos. Em certo sentido, o seu conjunto de filmes baseados em movimentos de câmera é a antítese do cinema de Brakhage, a contraparte ótica e sistemática do fluxo háptico da última fase de Brakhage - a identificação da câmera com um ponto de vista inteiramente pessoal, no desenvolvimento do filme lírico, é o inverso da mecanização dos movimentos e a identificação da câmera com um puro processo tecnológico aplicado ao espaço nos filmes de Snow. Rivette também demonstra um interesse particular no espaço, mas o faz pelo que descreve como a autonomia da mise en scène, "um complexo animado que parece suspenso no espaço". Em vários momentos isso se aproxima de uma coreografia no espaço fílmico, uma série de movimentos que envolvem as relações espaciais entre os personagens e entre estes e a câmera. Essas coreografias se inserem num contexto dramático, mas não se limitam a ele: especialmente nos momentos que envolvem a encenação como o próprio tema, as coreografias surgem com alguma autonomia, como ilhas próximas do continente narrativo. É importante que Rivette parta do drama, que ele elabore a fundação para estes momentos: é o fato de estarem enraizados firmemente numa realidade dotada de sentido e direcionamento que evidencia o quanto desses momentos parece uma diminuição da atração gravitacional do drama.

\footnotetext{
${ }^{276}$ Cf. Rohmer, "Isou ou les choses telles qu'elles sont", in Cahiers du Cinéma, n 10, março de 1952, pp. 27-28.

${ }^{277}$ Cf. Brakhage, “The Silent Sound Sense”, in Film Culture, n 21, verão de 1960, pp. 65-67.
} 
Por outro lado, a exploração do espaço nos filmes de Snow é, já de início, desligada do drama. Sua preferência por operações repetitivas e por variações fazem com que qualquer evento nas imediações do cenário possam apenas sugerir os contornos de uma narrativa (as pessoas que entram na sala em Back and Forth; os acontecimentos no apartamento em Wavelength), mas o movimento geral do filme vê esses eventos como "de passagem”, como partes de algo mais amplo. É este ponto que torna o controle de durações nos filmes de Snow algo a ser determinado por questões externas àqueles espaços, e relativas às próprias operações da câmera ou da montagem. Assim como Brakhage deve buscar outras referências quando se afasta do encadeamento lógico do drama, Snow deve ordenar seus planos de acordo com seus "resultados", para construir a estrutura desejada.

A diferença das duas abordagens está evidentemente ligada à filiação de cada um às respectivas tradições: é a ligação de Rivette com o realismo que faz com que o espaço em seus filmes seja sempre em profundidade, com a superfície da película "neutralizada", e som ou montagem reforçando essa unidade, assim como é o lado formalista de Snow que faz com que o espaço em seus filmes passe por diferentes "estados", incluindo a profundidade e continuidade como apenas um caso-limite, ao lado da ênfase na superfície fílmica e do questionamento das referências físicas (a gravidade em La Région Centrale, a velocidade em Back and Forth). Quando surge algum tipo de abstração nos filmes de Rivette, ela decorre da trama, como algo que determina as funções ou qualidades dos corpos no espaço - e que nunca parece negar suas presenças, apenas ressignificá-las. Quando Snow interfere no espaço com o som, e principalmente com a linguagem falada, é para torná-lo mais confuso, ou para revelar as ambiguidades possíveis nessas relações.

Em uma entrevista a Jonathan Rosenbaum, ao ser perguntado sobre a vanguarda americana, Rivette responde:

Eu gostaria de ver mais; eu vi muito pouco. Eu tinha algumas reservas com esse tipo de cinema, que para mim era associado a cineastas cuja obra não me interessava de maneira alguma, como Kenneth Anger, ou alguns filmes de Curtis Harrington. Foi apenas recentemente que aconteceu de eu ver filmes completamente diferentes: dois de Michael Snow dos quais gostei bastante, Back and Forth e La Région Centrale, apesar de não terem relação com o tipo 
de cinema que eu faço. Também fui surpreendido por filmes de Ken Jacobs (Tom, Tom, the Piper's Son) e Peter Kubelka (Unsere Afrikareise). ${ }^{278}$

Rivette não comenta sobre outros filmes e cineastas, mas podemos nos ater aos nomes citados por ele neste trecho. Kenneth Anger e Curtis Harrington são ambos associados ao primeiro momento da vanguarda, identificado por Sitney como dominado pelo filme de transe: o filme como um veículo de expressão, e que busca encenar conflitos internos através de metáforas e da construção de um espaço que segue uma lógica onírica, e que mesmo ao receber um princípio totalizante, como no filme mitopoético, se refere acima de tudo à projeção de uma consciência sobre o mundo representado. Em outras palavras, há aqui uma ligação estreita com o caligarismo, seja por distorções na imagem ou na montagem. Rivette, na época já explorando as preocupações com a encenação em suas próprias obras, naturalmente se interessa mais pelo momento seguinte, que compreende Snow, Jacobs e Kubelka, em que o espaço é explorado mais diretamente como uma categoria fundamental, e que a noção de uma consciência prévia projetada sobre a forma dá lugar a uma forma que parece pensar a si mesma. Isso é menos evidente no filme de Kubelka, que se volta mais para as relações polissêmicas entre os planos, e que apenas através da montagem revela o quanto a localização dos corpos e o sentido dos movimentos depende do ritmo e da duração. Mas no filme de Jacobs o espaço ganha um caráter elementar, sendo apresentado alternadamente como ilusão em profundidade e como resultado da constituição do material. E nos dois filmes de Snow, finalmente, o espaço em profundidade é abordado com um olhar mais próximo ao de Rivette, que parece se ater ao reconhecimento das distâncias, dos ângulos, da gravidade da câmera como fator crucial nos movimentos. As referências humanas são completamente diferentes em Back and Forth, e inexistentes em La Région Centrale, mas a fisicalidade do espaço é um dado obsessivamente atirado sobre a tela. Nos momentos mais extremos de Rivette, vemos o espaço ganhar vida através da câmera e dos personagens; nesses filmes de Snow, vemos o drama do espaço e da câmera, como se a figura humana já não fosse mais necessária.

Mourlet e Kubelka talvez sejam os mais radicais entre os autores considerados, defendendo diretrizes extremamente específicas e diametralmente opostas. Um ponto

\footnotetext{
278 Rosenbaum, "Phantom Interviewers over Rivette", in Film Comment, n 10, set/out de 1974. Disponível em: http://www.dvdbeaver.com/rivette/ok/phantomint.html. Acesso em Julho de 2014.
} 
comum entre eles está na asserção de que o registro da realidade pela câmera não é o suficiente, e que essa realidade, se "intocada", é amorfa, inexpressiva: a força do cinema surge a partir de uma articulação dessa realidade, de uma série de conflitos que cada um deles leva para uma direção diferente.

O confronto central para Mourlet é entre o homem e o mundo, tanto entre o cineasta e o real que ele toma como matéria, quanto entre os atores e o espaço cênico. Mourlet considera esse confronto em sua fisicalidade, e reconhece na violência uma espécie de energia a ser direcionada e focada pela mise en scène. Por essa razão, suas exigências quanto aos métodos envolvidos na encenação são mais rigorosas que as de Rohmer ou Rivette: não há espaço para o desdobramento do caráter documental como um movimento interno da narrativa, ou para uma exploração do caráter puramente espaço-temporal de uma movimentação de câmera em determinado cenário; o drama, centrado no herói, deve conduzir a energia da mise en scène por um olhar direto e um encadeamento necessário. O corpo dos personagens deve ser privilegiado, pois é em suas reações, na manifestação epitelial dos conflitos, bem como nas proporções entre os corpos e o espaço enquadrado pela câmera, que a realidade é apreendida pelo espectador.

A interpretação de Kubelka para a realidade sensível como algo "amorfo" é semelhante à de Arnheim e Vertov. Como eles, Kubelka acredita que os aspectos que aproximam a representação fílmica da impressão de realidade são negativos, pois permanecem inferiores à realidade em si, sendo uma transposição desta para parâmetros mais restritos. A composição no cinema deve então considerar esses parâmetros, considerar seus próprios materiais, e deles gerar os elementos a serem articulados. É nesse sentido que há uma semelhança sutil entre Kubelka e Mourlet: assim como Mourlet procura os conflitos entre o homem e o mundo, e propõe uma medida para os diferentes resultados (sua ordenação de cineastas, considerando a representação da violência em cada um deles), Kubelka busca os diferentes conflitos possíveis no material fílmico, entre diferentes fotogramas, e entre sons e imagens, para estabelecer uma escala a ser utilizada na composição dos filmes.

Arnulf Rainer é paradigmático nesse sentido. Kubelka reforça que, ao testar as diferentes possibilidades de articulação entre fotogramas e sons, estava descobrindo as leis fundamentais do material. O que Mourlet vê nas irrupções narrativas, nos momentos de pico da curva dramática, Kubelka vê no puro choque entre os elementos. 
Se a beleza para Rohmer deve surgir das próprias coisas, os contrastes e a dinâmica da composição para Mourlet devem surgir da relação entre os atores e o cenário, no "acordo entre o gesto e o espaço"; e se, por outro lado, Rivette "neutraliza" a superfície fílmica para se focar no espaço em profundidade, Mourlet rejeita a violência gráfica de Eisenstein. Em Arnulf Rainer, é justamente o espaço do fotograma, desprovido de profundidade, que ganha proeminência. O mesmo ocorre com o controle das durações: Mourlet exige que elas sigam as necessidades dramáticas, enquanto Kubelka privilegia as medidas materiais e métricas da faixa de filme.

\section{Territórios intermediários}

Em 1959, Alain Resnais lança Hiroshima Meu Amor (Hiroshima Mon Amour), sua primeira incursão no cinema de ficção e a primeira de suas colaborações com romancistas contemporâneos - neste caso, Marguerite Duras, autora do roteiro. Emmanuelle Riva interpreta uma atriz francesa e Eiji Okata um arquiteto japonês; ambos têm um breve caso em Hiroshima, onde a personagem de Riva participa de uma filmagem sobre a guerra. No início, vemos apenas partes dos dois corpos, abraçados e restritos num espaço que parece ser o de uma cama. Resnais corta para diversos eventos enquanto o diálogo entre eles prossegue: os comentários e memórias do casal são alternados com imagens de filmes sobre os efeitos da guerra, com passeios da câmera pelas ruas e museus da cidade. Aos poucos somos apresentados ao contexto mais amplo da situação, até que o final das filmagens e a possibilidade de a atriz deixar Hiroshima trazem o conflito que resulta da tensão entre a atração mútua dos dois personagens e a vontade da atriz de cobrir o passado e tudo que se refere a ele.

Quando os Cahiers organizam um debate sobre o filme, os diferentes posicionamentos se evidenciam imediatamente. Rohmer é mais reticente, apesar de reconhecer os méritos; ele diz que algo no início do filme (na parte que alterna planos do casal com planos dispersos da cidade) o incomoda, mas que é certamente uma obra importante. Rivette parece mais em consonância com a direção proposta pelo filme; ele analisa sequências inteiras de maneira minuciosa, como que descrevendo os princípios de composição por trás delas. Na discussão sobre as prováveis influências, Rohmer 
sugere a literatura americana moderna (a mesma citada por Bazin sobre Welles), ao que Godard acrescenta uma referência musical, dizendo que o filme de Resnais seria "Faulkner mais Stravinsky".

Rivette comenta que Hiroshima deixa clara a "grande obsessão de Resnais", a separação do mundo, de uma unidade primária, em fragmentos, que são então remontados como num quebra-cabeça.

Eu acho que para Resnais essa reconstituição de peças opera em dois níveis. Primeiro no nível do conteúdo, da dramatização. E então, acho que mais importante, no nível da ideia do próprio cinema. Eu tenho a impressão de que para Alain Resnais o cinema consiste em tentar criar um todo com fragmentos que são a priori diferentes. Por exemplo, em um filme de Resnais dois fenômenos concretos que não possuem qualquer relação lógica ou dramática são ligados unicamente por serem ambos filmados por travellings na mesma velocidade. $^{279}$

Mais adiante no debate, Rivette diz que a montagem em Resnais, como em Eisenstein, consiste em um duplo movimento, na ênfase da autonomia do plano e simultaneamente na busca pela força que o plano traz em sua relação com outros planos. A dicotomia entre a unidade de cada elemento como um bloco sólido, e o choque ou combinação de diferentes blocos para formar uma unidade em nível superior - o que faz com que Rohmer se refira a Resnais como um cubista.

A operação de fragmentação seguida de reintegração é feita ao nível da própria dramaturgia, como lembra Rivette. Os personagens são, literalmente, construídos; somos apresentados a partes de seus corpos, bem como de suas histórias, tanto quanto às partes e histórias da guerra. É apenas no decorrer do filme, no acúmulo das partes e nos diferentes encaixes entre elas, nas passagens da narração e da música por entre essas estruturas - como o ar que as atravessa e parece dar-lhes o tom - que reconhecemos o universo com o qual Resnais lida, e que na parte final do filme será confrontado mais diretamente (as últimas cenas abandonam a fragmentação; Resnais se foca em alguns momentos do casal vagando à noite pela cidade). Em aproximadamente um terço de sua duração, Hiroshima funciona de fato como uma construção cubista, um espaço que deve ser investigado, que convida o espectador a isto, que propõe um sentido apenas na

${ }^{279}$ Rivette, "Hiroshima, notre amour", in Jim Hillier, Cahiers du Cinéma, vol. I, p. 60. 
medida em que há do outro lado da equação uma consciência apta a realizar a ligação de suas partes. Há uma unidade, uma totalidade, mas ela não é apresentada de maneira homogênea.

Um ponto na citação de Rivette merece destaque: o fato de que "dois fenômenos concretos que não possuem qualquer relação lógica ou dramática são ligados unicamente por serem ambos filmados por travellings na mesma velocidade". Essa escolha, do ponto de vista formal, e principalmente no contexto fragmentário do filme de Resnais, é um afastamento considerável das diretrizes propostas por Bazin. Ao estabelecer uma relação entre os conteúdos pelo controle de seus parâmetros "superficiais", independentes daquilo que representam, Resnais estaria dando um passo além de Astruc, para quem a prioridade da ideia interior da cena ainda deve manter a integridade do espaço e a continuidade geral do tempo narrativo. Quando Resnais corta do casal no quarto para uma série de travellings pelas ruas da cidade - mantendo o diálogo do casal na faixa sonora -, duas unidades temporais são sobrepostas; e principalmente quando ele corta para diferentes planos num mesmo espaço (o museu da guerra, por exemplo), percebemos que a temporalidade desse mesmo espaço é inteiramente submetida à temporalidade evocada pela voz do casal, como se o diálogo, que ocorre no espaço do quarto, servisse como um disparador de imagens, um acesso momentâneo ao arquivo de memórias e registros que formam os eventos comentados. O princípio de composição adotado por Resnais confronta diretamente as exigências de continuidade que rejeitam o flashback ou o acesso ao fluxo de consciência e memória dos personagens (para não dizer coletiva), e chega mesmo a problematizar essa concepção na medida em que o filme não diferencia ou evidencia o caráter dessas imagens.

Uma discordância maior surge em relação ao filme seguinte de Resnais, $O$ Ano Passado em Marienbad (L'Année dernière à Marienbad, 1961), fruto de sua colaboração com Allain Robbe-Grillet. A narrativa que serve como ponto de partida para o filme envolve o que parece ser um triângulo amoroso num hotel de arquitetura barroca: um homem (Giorgio Albertazzi) tenta convencer uma mulher (Delphine Seyrig) de que eles se envolveram no ano passado e que concordaram em se encontrar naquele mesmo hotel, enquanto um segundo homem (Sacha Pitoëff) intervém em alguns momentos como se tentasse impedir o diálogo. O filme se desenvolve como uma série de variações sobre esta situação, numa montagem que embaralha as referências 
espaciais e temporais - se em Hiroshima as reminiscências disparavam cenas que dependiam do núcleo central dos dois protagonistas, em Marienbad todo o espaço do hotel e todas as camadas temporais referidas pelos personagens se confundem. Retornam aqui os procedimentos citados por Rivette em Hiroshima, os constantes travellings pelos corredores, a manutenção de um ritmo lento que acompanha a música e a narração (um órgão que permanece estável em altura e volume, e um fluxo de comentários do personagem de Albertazzi, ambos surgindo e desaparecendo da faixa sonora com certa independência da imagem), sendo postos em evidência tanto quanto as interações entre os personagens, como se houvesse uma arquitetura própria dessa estrutura espaço-temporal, na qual o andamento e a malha de planos e travessia de camadas seria uma espécie de apresentação descritiva.

Noel Burch cita o filme de Resnais como um exemplo da dialética temporal possível na composição. Ele descreve os diferentes modos de organização dos parâmetros numa analogia ao serialismo. O que Webern descreve como o objetivo final do serialismo - a unidade completa no interior da composição - seria alcançada pela recorrência estrutural de um mesmo tema através de suas variações possíveis. Num caso limite, tudo parece representar o mesmo tema, mas nenhuma dessas representações é exatamente igual às outras. Burch descreve algo semelhante em Marienbad, onde

\footnotetext{
cada sequência (ou cada plano-sequência) se refere a uma ou várias outras sequências num "tempo" (em sentido gramatical) que é talvez o passado, talvez o presente, talvez o futuro. Esta dialética da incerteza com várias variáveis engendra nela própria estruturas complexas independentes de estruturas da intriga (variações sobre temas: a estátua, a mulher na balaustrada) ou da planificação (organização dos movimentos de câmera, as dimensões dos planos, as elipses, etc). ${ }^{280}$
}

Considerando essas descrições, podemos nos voltar para duas reações ao filme, ambas do mesmo ano, em duas edições dos Cahiers, como exemplos de divergências que essas estratégias suscitavam no universo da crítica francesa no qual Bazin esteve inserido.

${ }^{280}$ Burch, Práxis do Cinema (Lisboa: Estampa, 1973), p. 79. 
André Labarthe, em seu texto sobre o filme, diz que o neorrealismo substituiu a concepção tradicional de roteiro por uma mais aberta, mais próxima da experiência real, apresentando, em vez de cenas, fragmentos separados por falhas ou intervalos, mais como pinceladas em uma tela e menos como um tecido intricado. Disso resulta que o espectador deve se tornar mais ativo: ele deve converter a descontinuidade da exposição numa continuidade interna. Essa demanda pela participação do espectador estaria também em Orson Welles; os neorrealistas não recorriam ao flashback, e Welles o evita a partir do segundo filme, o que Labarthe diz ter ocorrido em função da busca por mais realismo, no abandono por qualquer recurso que quebrasse a cronologia "natural". O que Resnais realiza é a sistematização desse princípio, tornando-o o próprio tema do filme. Em Marienbad, os planos, como as camadas temporais da trama, são situados como num objeto bidimensional cujas partes partilham um mesmo nível de realismo, mas na qual passado e futuro não constituem lembranças ou previsões, e sim ocasiões reais. A profundidade, ou ainda a "ordem" que elas propiciam, é criada pelo espectador, é a própria construção do objeto pelo espectador. ${ }^{281}$

Jean Douchet, num texto do mesmo ano, na edição seguinte da revista, toma uma perspectiva negativa. Ele identifica na concepção do filme o princípio que Bazin tentou manter distante do cinema que defendia, e que Rivette também parecia evitar em Anger e Harrington: a penetração da câmera no mundo mental. Marienbad é descrito por Douchet como "uma versão moderna, talentosa, inteligente, de uma extrema beleza, e tudo mais que se queira, de Caligari". A semelhança estaria na deformação das aparências, o que no filme de Wiene ocorre na plasticidade do espaço, e que em Resnais teria lugar na plasticidade do tempo. O fato de os movimentos de câmera tomarem uma função diferente daquela descrita por Rivette em Hawks (ou seja, uma função pragmática, transparente, voltada e integrada à narrativa) também é visto negativamente. $^{282}$

Lembremos do que Frampton chamou de "deslocamento" na obra literária de Robbe-Grillet: a negação das ligações causais, tornadas irrelevantes, e a identificação do texto com a ilusão de uma imagem plana, descrita minuciosamente em seus atributos

${ }^{281}$ Cf. Labarthe, "Marienbad Year Zero", in Jim Hillier (ed.), Cahiers du Cinéma, vol. II - 1960-1968: New Wave, New Cinema, Reevaluating Hollywood (Cambridge: Harvard University Press, 1986), pp. 54-55.

${ }^{282}$ Cf. "Venise 61", in Cahiers du Cinéma, n 124, outubro de 1961, pp. 42-43. 
espaciais. Essa é a estratégia reconhecida por Labarthe e Douchet em Marienbad, e descrita pelo próprio Robbe-Grillet:

O universo no qual se desenrola o filme é, de maneira característica, o de um presente eterno que torna impossível qualquer recurso a memória. É um mundo sem passado que se basta a si mesmo a cada instante e que se apaga gradativamente. Esse homem e essa mulher apenas começam a existir quando aparecem na tela pela primeira vez; antes, não eram nada; e, uma vez terminada a projeção, não são mais nada novamente. A existência deles dura apenas o que dura o filme. Não pode haver realidade fora das imagens que são vistas, das palavras que se ouvem. [...] Assim, a duração da obra moderna não é de modo algum um resumo, uma condensação de uma duração mais ampla e mais "real" que seria a da anedota, da história contada. Há, pelo contrário, absoluta identidade entre as duas durações. Toda a história de Marienbad não se passa nem em dois anos, nem em três dias, mas exatamente em uma hora e meia. [...] Mas, poderão dizer, que representa, nessas condições, as cenas às quais assistimos? Em particular, que significam essas sucessões de planos diurnos e noturnos, ou essas bem numerosas trocas de roupas, incompatíveis com uma duração tão curta? Evidentemente, é aí que as coisas se complicam. Só pode se tratar aqui de um desenrolar subjetivo, intelectual, pessoal. Essas coisas devem estar acontecendo na cabeça de alguém. Mas de quem? Do herói narrador? Ou da heroína hipnotizada? Ou então, por uma constante troca de imagens entre eles, na cabeça dos dois juntos? Seria melhor admitir uma solução de uma outra espécie: assim como o único tempo que importa é o do filme, o único "personagem" importante é o espectador; é em sua cabeça que se desenvolve toda a história, que é exatamente imaginada por ele. ${ }^{283}$

Há uma razão para que a tendência realista considere essas operações “arbitrárias", pois elas não se submetem ao princípio que integra o espaço e o tempo no desdobramento psicológico da causalidade que molda a narrativa. Bazin e Douchet, assim como Mourlet, não exigem que o cinema se submeta completamente ao encadeamento lógico de aparências; mas ao se apoiarem nessa integração, nessa "abertura ao mundo" que é proporcional à quão afirmativa ela se torna sobre o sentido

283 Robbe-Grillet, "Tempo e descrição no romance atual”, in Por um Novo Romance (São Paulo: Nova Crítica, 1969), pp. 102-103 
reconhecido pelo espectador (que é uma abstração inevitável na composição fílmica, como Bazin nos lembra), ambos se colocam numa região dessa escala mais distante daquela que parece ser a fonte do filme de Resnais. A arbitrariedade não é uma consideração falsa; a margem para o "arbitrário" é devido ao fato de a composição da obra não se reportar primeiramente à unidade da "experiência compartilhada", ou mesmo à unidade psicológica da experiência apresentada, e sim às características mais próprias do meio de expressão. Em Rohmer, por exemplo, o ritmo, o andamento, o tom de cada plano, de cada cena, os pontos de ligação e o direcionamento da narrativa, podem ser vistos como surgindo "do interior" da realidade, como um resultado da coordenação da realidade - Douchet diz ser este o programa de Baudelaire, "trazer à tona o que há de dentro pelo que há fora". ${ }^{284}$ A partir do momento em que Resnais e Robbe-Grillet deixam de se referir a esta realidade da mesma maneira, o componente arbitrário é introduzido, e o filme se torna uma composição mais abstrata no sentido de que diferentes modos de combinação daqueles planos - daqueles blocos reais nos quais os personagens se movem e nos quais reconhecemos os espaços e as ações - são possíveis. As cenas se tornam uma espécie de vocabulário, como aquele descrito por Kubelka na composição de seus filmes, ou como numa escala musical. A comparação com a música talvez seja ainda mais apta, pois os princípios de organização do material parecem se abrir a ordens que não são necessariamente psicológicas, mas epistemológicas: elas não se voltam ao conteúdo apresentado, mas às categorias de apresentação e percepção desses conteúdos.

A apreensão do espaço em profundidade através da relação entre a câmera e os espaços, e as alterações das proporções plásticas através da movimentação da câmera e dos atores, são exploradas por Resnais, assim como por Rivette. Mas o "deslocamento" temporal do filme faz com que a ligação entre os planos forme uma unidade distinta, como aquela descrita por Robbe-Grillet. Resnais mostra em certo momento o casal de protagonistas no centro do quadro, sobre um fundo claro e bem iluminado; o homem convida a mulher para uma dança, fazendo um gesto com a mão; ela aceita, e num breve intervalo, Resnais corta para outro lugar, com uma iluminação diferente, mas em que o casal também se encontra no centro do quadro, e seus gestos parecem uma continuação dos gestos vistos no espaço anterior. Esta é a mesma estratégia de Maya Deren em At Land, mas aqui Resnais não desenvolve uma trajetória claramente definida para seus

${ }^{284}$ Douchet, art. cit. 
personagens: toda a atenção se volta para a construção dessa estrutura mental que envolve os personagens, o hotel, e mesmo o esqueleto narrativo que é sugerido, mas não é identificada com nenhum desses elementos. Em At Land há o temperamento típico dos filmes de transe, e todas as alterações no espaço se reportam à jornada da protagonista: seus movimentos são contínuos, e ela é o elo entre esses espaços; em Marienbad há apenas a construção, como se o filme fosse identificado com o hotel em toda a sua ambiguidade espacial e temporal. ${ }^{285}$

Uma discordância semelhante à de Labarthe e Douchet surge entre os teóricos da vanguarda americana, em relação a Wavelength. Annette Michelson descreve a manutenção da integridade espaço-temporal do apartamento como uma instância fundamental do filme, a base sólida sobre a qual Snow elabora "os contornos de uma narrativa". Wavelength, segundo Michelson, define esses contornos através de seus aspectos mais elementares: as concepções de direcionamento, de expectativa, de redução de possibilidades, e principalmente, do espaço como definido pelo tempo. ${ }^{286} \mathrm{~A}$ estratégia de Snow é vista positivamente, como uma incorporação de aspectos narrativos no objetivo geral da mímese da consciência. É a partir deste ponto que Michelson argumenta que o filme opera como uma metáfora da narrativa: a narrativa é vista como análoga à "experiência direta", e o filme a inclui junto de outras esferas da experiência, próprias do material fílmico.

Malcolm LeGrice reconhece as mesmas características, mas sua interpretação é negativa. Ele argumenta que o desenvolvimento do cinema de vanguarda se direciona à exploração da dimensão concreta dos filmes, e mais ainda, da dominância dessa dimensão. A identificação do zoom com o apartamento seria a razão de uma correspondência importante: entre o tempo da projeção do filme e o tempo do registro do espaço. Essa correspondência seria perdida durante as sucessivas intervenções de Snow (os cortes para os blocos cromáticos, por exemplo). Mas acima de tudo, é a inclusão das referências narrativas - independente de quão mínimas elas sejam - que

\footnotetext{
${ }^{285}$ Uma estratégia parecida, ainda que mais dependente da narrativa, é utilizada por Stanley Kubrick em O Iluminado (The Shining, 1980). A integração da câmera à arquitetura labiríntica do hotel é fundamental na construção de algumas cenas que confundem a orientação histórica dos personagens. Vagando pelos corredores e investigando alguns cômodos da mesma forma que buscam a saída do labirinto propriamente dito, eles encontram corpos e objetos de outras épocas, como se diferentes camadas temporais fossem sobrepostas naquele espaço, como se a confusão espacial refletisse a confusão temporal. A própria resolução do filme - a fotografia na parede do hall, mostrando Jack Torrance (Jack Nicholson) em 1926 - sugere essa sobreposição, bem como o comentário de um dos fantasmas, de que Jack "sempre esteve ali".

${ }^{286}$ Cf. Michelson, "Toward Snow", in Sitney, The Avant-Garde Film, op. cit., pp. 174-176.
} 
LeGrice vê como um retrocesso no desenvolvimento da concepção material do cinema. O interesse de Snow na dialética entre o evento e a construção do evento é criticado por ele, que defende a predominância da construção fílmica em detrimento de qualquer evento "externo" (como em Arnulf Rainer). ${ }^{287}$

Esses exemplos apontam para mais que um reconhecimento, uma aceitação de certas obras como partes de um contexto a ser abordado. Tanto Resnais como Snow são vistos como partes das áreas a serem analisadas por esses críticos; eles são vistos como relativamente próximos das preocupações correntes de cada uma das vertentes, e as discordâncias surgem como tentativas de definir as fronteiras dessas vertentes através de questões comuns. A mesma oposição é vista nos dois filmes, e nos dois casos há uma defesa e uma negação, por autores que se encontram num mesmo círculo de influências. Há uma tensão interna em cada um deles, e que talvez possamos considerar como a indicação de uma área mais nebulosa, em que a própria divisão entre os dois hemisférios se torna mais ambígua.

Se nos colocarmos em busca de outra maneira de abordar essa ambiguidade, podemos nos voltar para casos em que não há um choque de opiniões nesse mesmo sentido, mas em que reconhecemos tópicos que normalmente seriam vistos como alheios àquelas tradições. Podemos nos perguntar se essa ambiguidade seria, em vez de uma característica própria de algumas obras, uma característica geral, e que simplesmente se torna mais evidente em casos mais extremos.

Consideremos, por exemplo, a filmografia de Rossellini. Em sua fase inicial, Rossellini serve como um epítome do realismo para Bazin. Até os filmes feitos com Ingrid Bergman, ainda que seu estilo passe por mudanças, há uma preferência clara dos autores dos Cahiers não tanto pelas especificidades formais, mas pelo temperamento de Rossellini - seu "respeito aos fatos". Tudo o que Bazin descreve sobre o quadro, o espaço da cena e a narrativa encontram expressão nos filmes desse período.

$\mathrm{Na}$ última fase de sua carreira, Rossellini se dedica a uma série de filmes feitos para a TV sobre diversas figuras históricas, desde Luís XIV e Cosimo de Médici até René Descartes e Blaise Pascal. A escolha de temas históricos, e de um recorte que privilegia discussões sobre o contexto político e filosófico, é apenas a primeira das diferenças entre esta fase e a fase inicial; a segunda, e maior delas, é uma reformulação dos métodos de abordagem cênica. Nesses últimos filmes, Rossellini baseia toda a mise

${ }^{287}$ LeGrice, Abstract Film and Beyond, op. cit., pp. 118-120. 
en scène em planos longos, movimentos de câmera cuidadosamente coreografados através dos cenários, e zooms que às vezes ocorrem mais de uma vez num mesmo plano. Estes procedimentos são o cerne da encenação, de modo que as qualidades evidenciadas por Bazin - a recusa à interpretação e a preferência pela "pureza e insignificância" dos fatos - sofrem um desvio considerável. Tag Gallagher comenta a relação entre essas duas fases da filmografia:

\begin{abstract}
Em contraste com o mundo fictício autocontido dos filmes com [Ingrid] Bergman, é perceptível nos filmes históricos que [Rossellini] está constantemente selecionando partes de um mundo cuja existência factual foi um tanto independente dos limites da ficção cinematográfica. No seu período neorrealista, a câmera de Rossellini não analisava, porque necessariamente já continha tudo em primeiro lugar: a ficção. Mas nos últimos filmes a câmera está constantemente colocada em uma dialética com as imagens históricas escolhidas por Rossellini. ${ }^{288}$
\end{abstract}

Por um lado, há ainda o respeito pelo caráter imediato do que está em frente à câmera, a realidade factual, a totalidade espacial mantida por Rossellini. Mas por outro lado, há uma preocupação com a maneira como essa realidade será apreendida, com o trajeto que o olhar faz sobre ela, a duração deste trajeto, e como a compressão e a expansão dos limites visuais podem funcionar como um microscópio e revelar detalhes, por este ângulo ou por outro, neste ou naquele momento. A coreografia da câmera no espaço cênico nos primeiros filmes de Rossellini não era ausente ou desimportante, mas não era enfatizada, não recebia o mesmo tipo de autonomia. Nos filmes históricos há um desprendimento da câmera da cena, ainda que sirva justamente para sintetizar a cena de outra maneira. O que Rivette identificava nas operações de montagem do cinema de Resnais é alcançado por Rossellini através da continuidade temporal.

O último filme de Rossellini talvez seja ainda mais extremo no desenvolvimento dessa postura. Em Beaubourg, centre d'art et de culture Georges Pompidou (1977), ele compõe um retrato do museu homônimo, num registro documental, com som direto, sem narração ou comentários. O mesmo método dos filmes históricos é utilizado, e a

\footnotetext{
${ }^{288}$ Tag Gallagher, Op. cit., p. 42. Gallagher defende que essa dialética é parte do método pedagógico de Rossellini, uma postura ativa sobre a História, uma interpretação dos documentos que servem de base para os roteiros e dos eventos encenados.
} 
composição é idêntica à trajetória da câmera de Rossellini. O filme se inicia com planos distantes do museu, observando a região da cidade onde ele se encontra. A combinação de zooms e panorâmicas aproxima gradualmente o olhar do que será o objeto de exploração; da mesma forma, cada corte nos leva para um plano ainda mais próximo, de modo que cada posição de câmera é como uma marcação espacial na cidade de onde Rossellini traça uma linha em direção ao museu. Quando finalmente chegamos a ele, a câmera passeia por suas imediações, observa as divisões do espaço, sendo às vezes atraída por um objeto particular. Em certo momento, a câmera está focada num prédio distante; um zoom out revela que ela está na parte externa de um dos andares do museu, ao lado de uma escultura; a câmera se move ao redor da escultura enquanto realiza um zoom in, observando seus detalhes; no decorrer do movimento, o zoom novamente se abre, revelando uma sala do museu com pessoas observando outras esculturas, ao que a câmera permanece estática por alguns segundos. Durante todo o plano, ouvimos os sons da cidade ao redor do museu, os ruídos do trânsito, o som de um avião passando, e no trecho final as vozes dos visitantes. Toda a progressão sonora é paralela à visual, mas em diferentes sentidos; os primeiros sons expandem o campo da "cena", e apenas em sua conclusão há uma sincronia aparente. Ainda que o som seja direto, seu direcionamento e posicionamento, ou seja, a seleção e mixagem, também são elementos fundamentais na elaboração da continuidade.

Essa autonomia da câmera é mais do que a exploração da amplitude espacial feita por Rivette. Ela se aproxima do que Brakhage descreveu como a identificação da composição com o próprio movimento da percepção - por outros procedimentos, obviamente, mas fazendo com que a totalidade cênica, as referências para os movimentos, as proporções no interior do quadro se refiram constantemente a um olhar desprendido dos objetos, um olhar que mesmo na aproximação através do zoom mantém seu distanciamento puramente posicional.

Noel Burch comenta como essa mesma autonomia da câmera se encontra em Antonioni, e como o fato de ele trabalhar com narrativas cria uma dialética semelhante à que Gallagher descreve em Rossellini, entre o que é falado pelos atores (a intriga propriamente dita) e a representação como um todo:

em vez de tentar recriar o espaço do teatro, como os americanos dos anos 30, em vez de procurar cercar com o máximo de discrição o jogo das personagens, 
como Dreyer em Gertrud, em vez de executar arabescos perfeitamente gratuitos à volta de uma encenação de uma teatralidade completamente banal, como Aldrich em The Big Knife, Antonioni compôs, entre as suas personagens que falam e a sua câmera que os vê falar, um tipo de relação que não saberíamos qualificar de outro modo a não ser pela palavra balé: um "balé" de uma riqueza e de um rigor sem precedentes. [...] Mas o que mais importa sublinhar aqui é que, ao contrário de Gertrud, por exemplo, os movimentos da câmera não dão de modo nenhum a impressão de seguir humildemente as deslocações "naturais" dos atores, nem de girar à volta destas deslocações em arabescos febris e arbitrários, como acontece muitas vezes com um Ophuls ou um Astruc: não, a estilização dos movimentos da máquina e a dos deslocamentos das personagens situam-se num estrito pé de igualdade, determinando-se mutuamente. [...] De fato, não é entre a câmera propriamente dita e as personagens, evidentemente, que se executa o "balé", mas entre estas e a extensão daquela no espaço que é o quadro. O desenvolvimento dinâmico do "balé" é esta constante renovação da imagem, obtida por todos os processos imagináveis, o reenquadramento, a passagem dos figurantes - mas, sobretudo, pelas mudanças de dimensão do plano e pelas entradas e saídas de campo. O quadro está em evolução constante, e eis o que constitui o elemento essencial [...]. ${ }^{289}$

Em outros capítulos de Práxis do Cinema, Burch explora o que denomina a “plástica da montagem", e um "repertório de estruturas dialéticas", numa tentativa de aproximação com os métodos da composição musical moderna. A ideia central do livro é a de que parâmetros puramente estruturais da composição (no nível do enquadramento, da cena ou da narrativa) podem adquirir a autonomia já citada. $\mathrm{O}$ mesmo tipo de conjunção que Eisenstein propunha no choque direto entre planos, na passagem de uma imagem à outra - o choque de linhas, de direções, de volumes, etc. são reconhecidos por Burch como que dissolvidos entre as imagens, não mais indicando uma relação de choque, mas se integrando à lógica narrativa. Um dos problemas que parece ser atacado com essas estratégias é aquele apontado por Kubelka, de que o cinema narrativo carece de um ritmo forte, de medidas claras as quais o cineasta articula em sua composição. A partir do momento em que a câmera não deve mais se reportar às

289 Práxis do Cinema, op. cit., pp. 96-97. Burch se refere a Crônica de um Amor (Cronica di un amore, 1950), mas os mesmos procedimentos são encontrados em diferentes momentos da filmografia de Antonioni, desde A Aventura (L'Avventura, 1960) até Profissão: Repórter (Professione: reporter, 1975). 
necessidades "internas" do drama, e que a montagem pode deixar de ser um "mal necessário" para contribuir ao sentido exposto pelos planos contínuos, o que surge é a possibilidade de criação independente de ritmos e divisões em cada um dos níveis da composição.

A "invasão" da montagem no cinema dito realista não é, evidentemente, um ponto cego ou uma raridade, podendo ser encontrada mesmo no cinema de Eisenstein que difere de Kubelka principalmente em sua consideração do plano como unidade fundamental, o que dá uma margem realista mais elevada para suas composições. No período de ascensão da Nouvelle Vague, Godard realiza, em um filme como Uma Mulher é uma Mulher (Une femme est une femme, 1961), uma integração mais autoconsciente desses procedimentos, fazendo com que a própria intervenção da montagem na transparência e continuidade das cenas seja um elemento autônomo, o fator cômico ou irônico daquele momento da narrativa como um todo. Mas há, nesse mesmo cinema, narrativo e realista, uma utilização da própria continuidade cênica como a base para uma "ritmização" do mundo, sem os procedimentos de câmera de Rossellini. Em Meu Tio (Mon Oncle, 1958), Jacques Tati elabora todas as cenas com grandes planos abertos e geralmente longos, nos quais toda a ação se desenvolve. É no desenvolvimento dessa ação, ou seja, na própria movimentação dos atores e na qualidade desses movimentos que Tati constrói uma verdadeira coreografia visual e sonora. Tudo passa a depender do modo como os personagens interagem com o cenário: no ruído característico dos interruptores, e como estes causam outros eventos (um portão é aberto ou fechado, o chafariz é ligado ou desligado); nos gestos cuja comicidade parece residir em seus aspectos mais superficiais (as caminhadas pelo caminho curvo e concreto no jardim, as diferentes vozes e calçados ecoando sobre os diferentes pisos como se cada personagem fosse um instrumento com seu próprio timbre e registro). O filme de Tati é uma orquestração da realidade, e uma ordenação de consonâncias e dissonâncias, de situações em que os desentendimentos e irregularidades parecem cair magicamente em posições harmônicas, para logo em seguida darem lugar a novas confusões e desequilíbrios. ${ }^{290}$

\footnotetext{
290 A presença dinâmica no filme, como o agente catalisador de todo o desequilíbrio, é Sr. Hulot, interpretado pelo próprio Tati. Bazin comenta como no primeiro filme com o personagem, As Férias do Sr. Hulot (Les Vacances de M. Hulot, 1953), ele opera, paradoxalmente, como um agente ordenador: todo o cenário parece plácido e desprovido de conflitos, de progressões, até que Hulot, com sua inadequação característica, cria um conflito após o outro, e coloca todo aquele mundo em movimento, criando mesmo a noção de um desenvolvimento temporal. Cf. Bazin, "Monsieur Hulot e
} 
Uma característica fundamental na presença de uma narrativa, ou mesmo de um contexto realista no cinema, é que essas operações podem ser tematizadas nos filmes, ou refletidas nos procedimentos técnicos de modo que a experiência da composição inclua algo como a metalinguagem que Carroll apontou em Serene Velocity. O texto de Annette Michelson sobre 2001: Uma Odisséia no Espaço (2001: A Space Odyssey, Stanley Kubrick, 1968) se concentra nessas características. Michelson aponta que toda a temática do filme, ao envolver a noção de exploração espacial, se coloca no mesmo plano que as técnicas utilizadas em sua própria encenação. Ela comenta como os enquadramentos, as cenas e a narrativa reformulam nossa concepção de espaço no decorrer do filme: como as referências de ângulo e posição são redefinidas a cada plano em que os astronautas se movem em ambientes com gravidade zero; ou como a estrutura dos espaços, especialmente as naves, e a relação entre a câmera e esses espaços, organizam movimentos que só são passíveis de percepção a partir dos parâmetros fílmicos (por exemplo, nas cenas em que os personagens caminham nos cenários giratórios enquanto a câmera permanece estática). Por essa ótica, o filme passa a ser interpretado como uma narrativa epistemológica, em que cada evento, ainda que se referindo a um arco dramático, possui raízes firmes na percepção "sensório-motora" do espaço. $^{291}$

Além da apreensão espacial, Michelson sugere que o corte, especialmente o corte como associado a Kuleshov, a operação mental por excelência, é utilizado como uma representação direta do pensamento. $\mathrm{Na}$ primeira parte do filme, logo após o encontro com o monolito, o filme encena o momento em que a luz da consciência teria alcançado a superfície através de um dos hominídeos: ele percebe, pela primeira vez,

o tempo", in Op. cit., p. 77: "Um mundo se ordena a partir de seu personagem, cristaliza como a solução supersaturada em torno do grão de sal ali jogado. É claro que o persongem criado por Tati é engraçado, mas quase que por tabela e, em todo caso, sempre em relação ao universo. Ele pode estar pessoalmente ausente das gags mais engraçadas, pois M. Hulot é apenas a encarnação metafísica de uma desordem que se perpetua muito depois de sua passagem." Em Playtime (1968), o personagem é retomado por Tati, mas não funcionando mais como o agente criador, e sim como um guia do espectador por aquele universo: é como se a dissolução de Hulot, a diminuição de seu protagonismo, fizesse com que outros personagens se tornassem Hulots em potencial, reforçando a condição de "encarnação metafísica" descrita por Bazin.

${ }^{291}$ Cf. Michelson, "Bodies in Space: Film as Carnal Knowledge", in Artforum, Vol. 7, n 6, fevereiro de 1969, p. 57: "[2001] propõe nada mais que o interesse radical em sua própria fisicalidade, sua 'declaração formal' sobre a natureza do movimento em seu espaço; [o filme] 'sugere' nada mais urgente e absorvente que uma evidência aos sentidos, seu discurso sobre o conhecimento através da percepção como ação, e finalmente, sobre a natureza do meio como 'filme de ação', como modo e modelo de cognição"; e p. 58: "O ato de ver se torna, como sempre, mas nunca como antes, a descoberta, através do reconhecimento da desorientação, do que é o ato de ver, aprender, saber, e o que é ser, enquanto se vê." 
que um osso não é apenas um objeto insignificante, mas pode ser direcionado a um fim, submetido a uma vontade. A maneira como a cena é montada é crucial, pois este momento é representado justamente pelo corte para a imagem do monolito, de modo que a associação feita pelo personagem e a associação feita pelo espectador convergem num mesmo período, em que o filme expõe, por sua própria construção, o fundamento do raciocínio.

Se estes procedimentos sugerem uma aproximação do realismo a características do formalismo, quais seriam os casos em que o cinema de vanguarda adere às práticas realistas? A consideração do plano como unidade básica é um tópico importante, assim como a ausência de abstrações e deformações do espaço.

Nos filmes de Peter Hutton, por exemplo, encontramos algumas das estratégias de composição que dominavam os filmes líricos de Marie Menken e Bruce Baillie: planos estáticos, em silêncio, registrando ações breves e desprovidas de qualquer caráter espetacular. A diferença de Hutton para os filmes líricos é que em seus filmes não há uma ênfase na subjetividade do observador, mas uma redução de sua intervenção ao mínimo possível, como se o mais importante fosse simplesmente observar. Em New York Portrait (dividido em três partes, de 1979, 1981 e 1990), Hutton se interessa claramente pelos elementos naturais na cidade: a fumaça que sai das chaminés, o reflexo do céu nas poças de água, o vento, a neblina, as nuvens que se movem sobre o horizonte de prédios. Os filmes passam por diferentes períodos do dia, e nos raros momentos em que pessoas são vistas, o enquadramento e a iluminação enfatizam a plasticidade de suas ações; elas são vistas de cima, com suas sombras projetadas sobre a calçada, ou vistas à distância, como pequenos traços se movendo lentamente, ou estáticas, como objetos integrados à paisagem.

Como filmes silenciosos e focados na observação, uma semelhança imediata é percebida entre Hutton, ou mesmo Menken, e o "primeiro cinema". O que diferencia esses filmes das vistas dos irmãos Lumière é a concepção da "moldura" que o plano cria ao redor do evento. Enquanto os enquadramentos dos Lumière eram amplos o bastante para que todo o contexto necessário fosse exposto de uma só vez, e para que as linhas de força das ações pudessem se desenrolar no interior daquele campo de visão, as observações líricas de Menken ou Baillie se voltam para recortes de situações maiores, como se a diminuição da distância entre o cineasta e os objetos revelasse um interesse mais esparso, quase meditativo, sobre os detalhes. Num filme como Notebook, toda a 
atenção é direcionada para o momento em que uma gota de água toca a superfície de um lago, de modo que temos um evento reconhecível, mas despido de tudo exceto seus aspectos mais imediatos - suas "referências puramente espaço-temporais", mas com uma ênfase considerável no recorte pontual dos eventos, se compararmos com as referências comentadas por Rivette.

Scott MacDonald comenta a granulação bastante presente em alguns filmes de Hutton com um fator que inicialmente poderia contradizer o desejo de "sair da frente" da paisagem, de desenvolver a transparência do olhar. Ele argumenta que essa granulação termina por reforçar a organicidade dos menores movimentos em cada plano; como grande parte deles é estática, cada alteração no interior do quadro, por menor que seja, parece saltar à vista; o movimento dos grãos, incessante e independente do que a câmera observa, seria uma espécie de microcosmo dos processos naturais tão presentes no filme, a prova de que os movimentos - tanto sobre a película como sobre a paisagem - são essencialmente luminosos. ${ }^{292}$

Em Study of a River (1996) e Time and Tide (2000), Hutton se concentra em lugares mais específicos, nas proximidades do rio Hudson. Ambos retomam a postura de seus filmes em Nova York, mas a figura constante do rio parece fazer com que a composição se torne dependente de menos condições, como se houvesse um diálogo mais direto entre como ocorre o registro e o que é registrado. Time and Tide é inteiramente filmado a bordo de um mesmo navio de carga, atravessando diferentes estações do ano, fazendo uso de negativos coloridos e preto-e-branco A maioria dos planos mostra alguma parte do navio, seja a proa, seja o convés ou as janelas no deque, ao mesmo tempo em que mostra o espaço ao redor do navio e do rio, as diferentes margens e trechos de cidades. Vemos o gelo espalhado pelo casco do navio enquanto ele passa pela água; partes da cidade através das janelas circulares, que funcionam como máscaras que cobrem a tela; o horizonte ao qual o navio se direciona, através dos vidros da sala de comando molhados pela chuva. A duração dos planos varia, e não há qualquer ênfase em uma estrutura, em uma estratégia específica que coordena os diferentes planos. A única operação recorrente é o período que separa os planos, em que Hutton mantém uma tela preta por alguns segundos. Time and Tide é uma coordenação de "vistas", e o controle de Hutton sobre alguns dos parâmetros envolvidos na filmagem 292 Cf. MacDonald, "Peter Hutton: The Filmmaker as Luminist", in Chicago Review, vol. 47, n 3 ,
outono de 2001, pp. 82-83. 
é sinônimo das escolhas mais simples reconhecidas pelos realistas, a nível do enquadramento e da ordenação.

Outro cineasta associado à vanguarda americana, e que compartilha com Hutton um interesse por paisagens, é James Benning. Em El Valley Centro (2000), Los (2001) e Sogobi (2002), Benning organiza uma série de registros no estado da Califórnia sob uma mesma regra: cada um dos filmes é constituído por 35 planos que duram 2 minutos e 30 segundos, e cada um deles apresenta a região do título, como um estudo descritivo da geografia através de medidas rigorosas de tempo e enquadramento. O controle preciso e pré-concebido das durações é um diferencial importante entre Benning e Hutton, além do fato de Benning fazer uso de som direto na quase totalidade dos seus filmes. $^{293}$

Benning define uma paisagem como "uma função do tempo", e se diz interessado no desenvolvimento daquele recorte espacial num período determinado. Essa preocupação se torna mais clara em seus filmes que selecionam um único evento ou fenômeno e exploram suas diferentes manifestações. Nos filmes da "trilogia da Califórnia", não há qualquer previsibilidade em relação ao que será visto a seguir; os filmes podem cortar de uma paisagem montanhosa para um lago, ou de um enquadramento centralizado e simétrico para outro completamente descentralizado. Mas em um filme como 13 Lakes (2004), Benning não apenas se atém a um único tema como a um mesmo enquadramento: o filme é composto por 13 planos, cada um deles mostrando um lago diferente, mas com as mesmas proporções visuais - o quadro sempre tem a mesma região ocupada por um lago, e a mesma região ocupada pelo céu. ${ }^{294}$ O mesmo ocorre em $R R$ (2007) e Ten Skies (2004): referenciais fixos funcionando como as fronteiras dentro das quais ocorrem algumas variações, respectivamente, as passagens dos trens e as transformações das nuvens.

\footnotetext{
${ }^{293}$ A primeira fase da obra de Benning é formada por filmes que se aproximam dos métodos do cinema estrutural. Sua abordagem das paisagens é desenvolvida no decorrer dos anos: no período anterior aos filmes da Califórnia, ele ainda mantém alguns dos interesses "estruturais", e explora as relações entre os registros em planos longos com a câmera estática e textos narrados (Deseret, 1995) ou textos sobrepostos graficamente às imagens (North on Evers, 1991). Ao mesmo tempo, há uma dimensão explicitamente histórica nesses filmes, no diálogo entre os documentos verbais e os registros fílmicos.

${ }^{294}$ Ver o documentário James Benning: Circling the Image (Reinhard Wulf, 2003). O filme mostra Benning numa espécie de pesquisa de campo para 13 Lakes, enquanto comenta seus preceitos e métodos.
} 


\section{As formas da realidade e a realidade das formas}

Em um texto chamado "Film and the Radical Aspiration", Annette Michelson aborda o que ela diz ser a "queda do paraíso" do pensamento teórico nas primeiras décadas do cinema. Ela descreve um cenário próximo daquele exposto por Frampton ao falar de Eisenstein: o surgimento do som como um fator responsável pela dissociação entre as pesquisas formais e o contexto industrial. Segundo este argumento, enquanto o cinema era silencioso, as possibilidades eram mais ou menos harmonizadas; discordantes quanto ao objetivo, mas complementares, e não contraditórias, em seus percursos. Os surrealistas, por exemplo, admiravam a comédia americana, ainda que seguissem um caminho que negasse alguns de seus pressupostos; Eisenstein escrevia um elogio a Griffith, ainda que desenvolvesse um método distinto; Dreyer apontava Eisenstein e Griffith como antecessores, ainda que seguisse um caminho diferente de ambos. Em resumo, todos partilhariam a crença de que o cinema deveria elevar o potencial da composição visual em movimento. Michelson comenta que a centralização dos materiais na rápida industrialização na passagem para o cinema sonoro gerou uma desconfiança entre os protagonistas desse cenário. A multiplicação do número de técnicos teria feito com que o caráter de exploração, de invenção, fosse diminuído, e a resistência à palavra teria tomado proporções cada vez maiores. ${ }^{295}$

A história do cinema moderno seria, assim, em grande parte, a história da reação a essa dissociação. É aqui que o argumento de Michelson se torna particularmente importante, em sua descrição dos principais caminhos tomados nas décadas seguintes:

É a aceitação deste princípio dissociativo, sua sublimação e conversão final em propósitos estéticos, que caracteriza a cinematografia recente e avançada na França e em outros lugares da Europa. É a rejeição categórica desse princípio e a aspiração de uma inocência e organicidade que anima os esforços da vanguarda americana. Toda discussão sobre a natureza e as possibilidades do cinema avançado hoje, da estética fílmica e de possibilidades futuras, deve, a meu ver, tomar essa divergência de radicalismos em consideração. ${ }^{296}$

\footnotetext{
${ }^{295}$ Cf. Annette Michelson, "Film and the Radical Aspiration", in Sitney (ed.), Film Culture Reader, op. cit.

${ }^{296}$ Ibid., pp. 405-409.
} 
Esta divisão se assemelha à que encontramos no decorrer dos capítulos anteriores. Por um lado, o caminho do qual Bazin é um dos principais representantes, e que é considerado também por Rohmer, Rivette, Astruc e Mourlet: um caminho que aceita a dissociação, que se propõe a atravessá-la, tomando suas contradições como elementos na composição, como a própria forma pela qual as obras viriam a existir. $\mathrm{O}$ mito do cinema total postula o direcionamento e os princípios que devem reger os métodos nessa caminhada: a aspiração final é a integração dos aspectos da realidade sob uma mesma ordem, que deve ser feita através da abertura ao mundo, da tendência centrífuga do quadro, do fator psicológico envolvido na narrativa, da restrição das interferências "arbitrárias" em nome da imanência capturada pelo potencial objetivo da arte. Este caminho defende que o problema descrito por Michelson deve ser atacado "por dentro" - por dentro da indústria, incluindo os elementos e gêneros utilizados por ela. A dedicação dos críticos dos Cahiers du Cinéma ao cinema de Hollywood, e o reconhecimento dos "autores" dentro do contexto industrial são pontos-chave nesta discussão.

Por outro lado, existiria o caminho do qual Frampton faz parte, o mesmo considerado por Sitney, Brakhage, Snow e Kubelka: um caminho que rejeita a dissociação, que se propõe a desviar dela como de um obstáculo, para que a caminhada em direção à pureza da arte não seja interrompida. O mito de uma contraparte da linguagem postula o direcionamento nessa outra caminhada: a aspiração final do cinema sendo a integração dos aspectos da consciência sob uma mesma ordem, que deve ser feita através da definição do material, da tendência metafórica do quadro, do fator abstrato envolvido na narrativa, do reconhecimento da objetividade como apenas uma possibilidade entre outras, e que não deve ser priorizada para que o potencial máximo seja alcançado. A vanguarda trabalha à parte das especificidades da indústria, o que se reflete na constante negação ou no ataque à narrativa, e na negação da própria concepção de que o cinema deve se referir a um contexto social. A "autoria" dos cineastas de vanguarda não deve, portanto, surgir das amarras industriais, mas de sua independência dessas amarras; da mesma forma, o "mundo sensível” é considerado exterior ao cinema, e surgem assim as diferentes tentativas de realizar filmes que não representem nada que não sua própria natureza fílmica, que não articulem nada que não seus próprios materiais. 
As tensões entre os dois lados parecem se resumir então em dois pontos: na maneira como o mito subjacente determina $o$ que será exposto e representado pelo cineasta-compositor, e na maneira como determina o direcionamento desses elementos.

Os elementos realistas devem ser necessariamente apreendidos da realidade, da unidade pressuposta pelo mito do cinema total. Essa é uma razão para que a tendência realista pareça mesmo resistente a se referir a esses aspectos como "elementos" - como se a própria aceitação dessa separação do mundo já constituísse uma etapa indesejável. Mas vimos como as diferentes abordagens realistas não se satisfazem com a mera apreensão, ou a mera utilização bruta do material visível. Tanto a cor como o som ou mesmo o movimento devem ter uma necessidade dentro da composição. $O$ fator recorrente na criação dessa necessidade, em todos os casos apresentados aqui como constituindo a tradição realista, é a narrativa. A narrativa é vista como uma espécie de princípio integrador, uma restrição e ordenação dos aspectos totais da realidade a partir de uma síntese - ou seja, ela deve manter intactas algumas dessas relações, em especial a impressão do espaço em profundidade e a continuidade dos eventos. Em resumo, a narrativa é o direcionamento desses elementos, aquilo a que Bazin se referiu como a polarização que não altera a constituição dos fatos.

Essa elaboração deve ser consciente, e é esta a medida de arbitrariedade, de subjetividade, que os autores e cineastas realistas parecem dispostos a aceitar, a “abstração inevitável”. O mínimo que pode ser articulado, a mínima escolha, a mínima presença do cineasta: esse parece ser o grau zero do realismo. E ainda assim, o controle, ao ser admitido como inevitável na composição, traz em grande parte dos casos a preocupação com a interação entre o controle e a improvisação, entre o arbitrário e o natural. Os autores realistas fazem o elogio da "pulsação do mundo", da "porosidade aos fenômenos", da "liberdade construída". A afirmação do cinema em suas especificidades e em suas propriedades materiais passa a ser aceita na proporção em que cada procedimento traz junto de si a possibilidade de uma manifestação que independe completamente do cinema, e que revela, em última instância, aquela mesma realidade inicial.

A escala humana parece ter importância crucial no realismo. O drama, como decorrência da narrativa, é geralmente visto como fundamentalmente humano. A associação feita por Bazin, do drama com o teatro, é um exemplo deste ponto de vista; mesmo quando Bazin comenta o aspecto "anti-antropocêntrico" do cinema, ele parece 
se referir acima de tudo a um potencial. É neste ponto que devemos reconhecer o quanto os outros autores revelam da própria postura de Bazin. O caso de Mourlet é o mais extremo, em sua eleição absoluta do homem como centro gravitacional de toda mise en scène; mas mesmo em Rivette ou Astruc (e nos cineastas que eles comentam), as relações entre a câmera e o espaço devem sempre passar pelo homem. Rohmer, talvez o que mais manifeste certa "abertura" ao mundo, ainda assim o faz através de uma postura baseada na narrativa, e principalmente na psicologia dos personagens. Quando Bazin se refere à "psicologia da narrativa", ele parece se referir essencialmente ao olhar do homem sobre um mundo que de certa forma pressupõe a presença do homem - ou seja, a "psicologia" é formada pelos conteúdos propriamente humanos, ou ainda, propriamente dramáticos da natureza, selecionados e ordenados. Isso não se manifesta apenas na simples visualização e orientação espacial, mas na própria concepção temporal e duracional da composição, numa proximidade com o que Aristóteles definiu como as necessidades da representação poética: ela deve ser feita de modo que possa ser apreendida como um único "movimento" e abarcada na memória; abaixo ou acima deste grau, a representação é vista negativamente. ${ }^{297}$

Se o realismo busca a integração e o direcionamento uniforme dos elementos, o "formalismo", ou as diferentes tendências da vanguarda, parecem se caracterizar justamente pela separação e reordenação desses elementos. Este processo passa, primeiramente, pela operação que Greenberg identifica no modernismo, a definição dos elementos constituintes a partir de uma redução aos aspectos materiais da arte. Em consequência disso, os elementos considerados pelos realistas - os gestos dos atores, os movimentos da câmera, as propriedades dos objetos e cenários (cor, som, movimento, etc.) são definidos no formalismo a partir do próprio aparato fílmico. O elemento fundamental passa a ser o fotograma, e as propriedades a serem reguladas passam a ser aquelas disponíveis a cada fotograma e a cada sequência de fotogramas. Podemos dizer, em termos gerais, que o formalismo tende a considerar os elementos "simples", isto é, aqueles que definem a própria existência da arte, enquanto o realismo considera apenas elementos "complexos", que resultam de uma concepção mais ampla, da qual a tecnologia do cinema é apenas a parcela menos importante. É nesse sentido que podemos considerar que o realismo reside sobre as fundações reveladas pela vanguarda,

\footnotetext{
${ }^{297}$ Cf. Aristóteles, "Poetics", in Louise Ropes Loomis (ed.), On Man in the Universe (Nova York: Walter J. Black, 1943), pp. 419-427.
} 
ainda que não as coloque em evidência. O realismo se caracteriza justamente por procedimentos que neutralizam os "elementos simples".

A partir dessa diferenciação, o intervalo entre os dois mitos pode ser tornado mais claro. O mito proposto por Frampton é o de uma contraparte da linguagem, e a analogia é inevitável se considerarmos a constituição da linguagem: ela não possui existência concreta, sendo formada por um conjunto de referências abstratas e operações que dão sentido a essas referências. Em outras palavras, a tendência a dispersar e reordenar os elementos decorre dessa analogia, pois é apenas com a definição e redução aos menores níveis possíveis que o cinema pode se tornar uma "máquina de expressão", e tomar consciência dos parâmetros encontrados em sua própria constituição, ou seja, os limites e especificidades de seu meio. Na medida em que isto o caracteriza como um "meio de expressão", ainda que ele não expresse nada além de si mesmo, é que o cinema se direciona para a afirmação de sua presença como a de um análogo da consciência - o que vimos tanto nos escritos de Frampton como na trajetória da vanguarda descrita por Sitney.

Mas assim como os nomes da vanguarda consideram o realismo apenas um caso especial dentro do vasto campo da máquina expressiva do cinema, eles também parecem considerar a escala humana e a narrativa como modos específicos, e não inevitáveis ou necessariamente desejáveis na composição das obras. Assim como uma linguagem pode ser utilizada de diferentes maneiras, constituindo não apenas dialetos, mas vocabulários inteiros a partir de um uso local, o cinema de vanguarda explora o princípio da dispersão no sentido de que a necessidade da composição pode seguir diferentes parâmetros, em diferentes combinações, em vez de se reportar ao princípio integrador e direcionador do realismo. Tendo rejeitado a narrativa como exigência, a representação como um todo e a posição do homem dentro dela passam a ser elementos disponíveis, mas não obrigatórios: a escala do cinema de vanguarda compreende desde a superfície do fotograma (ou seja, a negação de qualquer realidade externa ao cinema) até a escala do espaço mecanizado e desprovido de referências humanas.

Podemos apontar exemplos paradigmáticos da vanguarda, que levam aos dois extremos que cercam o "núcleo" do realismo. Por um lado, as premissas realistas, se levadas às últimas consequências, e principalmente se ultrapassarem os referenciais descritos, podem resultar num filme como La Région Centrale, ou mesmo Empire, que parece elaborar sua duração como uma extensão de seu espaço: há a neutralização do 
substrato material do filme (a superfície do fotograma, a natureza contínua da faixa de filme, a granulação), uma dissolução dessas características, como se o filme pudesse dar conta de seu pretexto numa forma holística identificada com ele; como se pudesse, por sua própria presença fílmica, produzir ou sugerir o objeto ausente. Por outro lado, um filme como Arnulf Rainer, ou Mothlight (Brakhage, 1963), reforça justamente o que os anteriores dissolvem: a materialidade da faixa de filme, sua natureza contínua (no caso de Mothlight), o achatamento e a restrição do quadro - e o que esses procedimentos evidenciam não é o caráter indicial de um objeto visto através do filme, mas o próprio filme como um objeto. ${ }^{298}$

A tendência realista se coloca, nos casos aqui tratados, como a defesa de uma concepção de mundo que parece funcionar como um núcleo conceitual, do qual tudo deriva e ao qual tudo se direciona. Frente à riqueza dessa realidade, da multiplicidade de sensações que os eventos apresentam em seu contexto natural e da intricada rede de causas coordenadas que conseguimos apenas intuir, toda transposição para signos ou símbolos, toda articulação e reordenação, toda linguagem, deve necessariamente parecer vazia, vaga, abstrata, revelando a impotência do meio frente ao objeto. O princípio considerado é de que, a partir do momento em que algo é reconhecido e isolado como um "elemento", como uma imagem consciente de sua dependência de uma interpretação - e principalmente quando seu uso recorrente faz com que se torne algo análogo a uma palavra, a um termo num vocabulário -, a partir daí, ocorre uma perda de aspectos essenciais, da ambiguidade e complexidade do real, e uma tendência a se tornar um lugar-comum. O interesse gerado pelo conteúdo "original” seria reduzido à teia semântica que resulta dessas sucessivas apresentações. O limite da intervenção se torna então o ponto em que ocorre esse desgaste, e as diretrizes dessa intervenção se tornam idênticas à necessidade de fazer com que esse elemento assuma uma nova identidade, uma nova realidade. A composição deve se voltar para a recarga de energia das imagens, para que cada uma delas possa se tornar algo como uma "imagem prima", divisível apenas por si mesma e pela unidade. ${ }^{299}$

Mas a expressão articulada não se pretende apenas uma representação do mundo; ela possui um caráter independente, que consiste na atribuição de sentido, e

${ }^{298}$ Cf. Paul Arthur, "Structural Film: revisions, new versions, and the artifact", in Millennium Film Journal, vol. 1, $\mathrm{n}^{\circ}$ 2, primavera/verão de 1978, pp. 5-11.

299 Duchamp utiliza a expressão para se referir às palavras, numa nota intitulada "Condições para uma linguagem". Ver Michel Sanouillet e Elmer Peterson (ed.), The Essential Writings of Marcel Duchamp (Londres: Hames and Hudson, 1973), p. 31. 
mesmo na revelação de sentido. Qualquer objeto, ao ser retirado ou abstraído de sua existência imediata, não é simplesmente apreendido pelos meios da arte, mas recontextualizado, tendo alguns de seus aspectos enfatizados e outros suprimidos. Se a realidade é entrevista apenas através de uma construção, ela pode ter sua impressão imediata ampliada pelas categorias espaciais e temporais bem como ser retraída pelas mesmas categorias, revelando as potencialidades sintéticas na proporção em que estas se identificam com os limites materiais do meio. O ideal de um cinema que canaliza "conteúdos da consciência" parece considerar que todo o conjunto de pretextos possíveis - ou seja, a realidade visível - de certa forma corresponde a essa ordem da consciência. É esta a herança do romantismo que Sitney reconhece na vanguarda americana, especialmente na figura de Ralph Waldo Emerson, para quem "partes do discurso são metáforas, pois a totalidade da natureza é uma metáfora para a mente humana". 300

Entre os dois extremos, como um espelho entre um corpo e seu reflexo, está a composição cinematográfica propriamente dita. Entre o sujeito e o objeto, está o "projeto" comentado por Bachelard, e um processo que mesmo Bazin considera envolver os dois pólos, ao dizer que "a tela reproduz o fluxo e refluxo de nossa imaginação, que se nutre da realidade à qual ela planeja se substituir". ${ }^{301}$ Tanto a representação que acredita sintetizar a natureza frente à câmera em uma forma aberta à complexidade, como a representação que acredita sintetizar a imaginação por trás da câmera em uma forma que sugira sua própria complexidade - ambas devem necessariamente convergir na estrutura da tecnologia cinematográfica. É nesse sentido que uma tentativa de descrição da composição no cinema parece se tornar uma tentativa de descrever como as formas da realidade e a realidade das formas se tornam uma única experiência, descrita nos termos materiais do cinema, mas não se atendo unicamente a eles. Como se a descrição do espelho, e das leis físicas envolvidas na formação das imagens, pudesse, indiretamente, descrever a relação interdependente entre o corpo e seu reflexo.

\footnotetext{
${ }^{300}$ Ralph Waldo Emerson, "Nature", in Carl Bode (ed.), The Portable Emerson (Nova York: Penguin, 1981), p. 24.

${ }^{301}$ Bazin, "A montagem proibida", in Op. cit., p. 90.
} 


\section{Considerações finais}

A intuição que deu início ao trabalho envolveu a busca por uma maneira de se referir, com um arcabouço conceitual comum, a filmes e autores de procedências tão diversas e distantes que seriam vistos como incomunicáveis - conceitualmente, pelo contraste dos pressupostos, e historicamente, pelo parco diálogo efetuado nos períodos e tópicos comuns. As escolhas nessa busca passaram inevitavelmente por tratamentos anteriores, com ênfase em diferentes aspectos desse cenário, entre os quais podemos citar os compêndios e comentários de Dudley Andrew, Noel Carroll e Ismail Xavier. Um ponto pacífico entre estes autores é que uma análise comparativa deste tipo deve se voltar para a própria constituição das teorias, com atenção especial para o fato de que "certos conflitos entre tendências diferentes, em geral aguçados por aquilo que elas explicitamente assumem e defendem", às vezes mascaram os pontos comuns entre elas, "principalmente quando nossa atenção é dirigida para aquilo que permanece implícito em cada proposta e cercado de um sintomático silêncio". ${ }^{302}$ Esse é o sentido das considerações no quarto capítulo sobre as semelhanças estruturais, e do que já na introdução foi proposto como uma espécie de princípio de complementaridade: a concepção do campo do cinema como uma área a ser descrita não em termos contraditórios, mas interdependentes.

O grau de arbitrariedade na eleição dos exemplos tratados, tanto os autores como os filmes, é de certa forma amenizado por alguns dos resultados. Considerar André Bazin como o epítome do realismo pode parecer historicamente adequado, mas posicionar Hollis Frampton como sua contraparte formalista soa duvidoso se feito pelos mesmos critérios; foi preferido por isso um equilíbrio entre o contexto histórico e o conteúdo propriamente dito das teorias, bem como entre as proposições teóricas e os exemplos fílmicos. As limitações dessa escolha são inevitáveis, e há quase certamente alguma problemática a ser derivada da terminologia empregada, mas o que deve ser considerado acima de tudo é que a divisão serviu como ponto de partida, não como o objetivo da discussão. Assim como há uma ênfase na definição e iluminação dos pressupostos de cada um dos autores, para que eles possam ser comparados com mais rigor, também nas denominações e classificações há um teor proposicional, como a

302 Ismail Xavier, O Discurso Cinematográfico (São Paulo: Paz e Terra, 2005), p. 165. 
aceitação de uma base específica para que outras características sejam postas em jogo. Se existem diferentes tipos de "realismo", ou se "formalismo" remonta a tópicos desligados daqueles tratados pela vanguarda americana, isto não significa que a dissertação tenha dado preferência a um ou outro sentido de cada termo; a terminologia serviu apenas para melhor compreendermos as relações, não para afirmar o que já era sabido de início. As limitações permanecem, mas o que deve ser enfatizado é quão melhor podemos entender o cinema dentro delas.

A primeira metade da dissertação, formada pelos três capítulos iniciais, ao se concentrar em Bazin e Frampton possibilitou a apresentação dos pressupostos, além de certo aprofundamento nas duas concepções teóricas, incluindo seus exemplos e referências particulares. Nesses capítulos pudemos ver como há alguma adequação dos dois autores a linhagens que remontam às primeiras décadas do pensamento sobre o cinema, e que já preparavam o solo para os tópicos por eles propostos. Através de sucessivas comparações, foram apontados os pontos de tensão e aproximação entre o pensamento de Bazin e Frampton, o que nos levou ao reconhecimento dos principais elementos ou ferramentas disponíveis à composição fílmica: o quadro, ou a tela; o espaço, seja o da cena ou o da própria película; e a narrativa.

A segunda metade da dissertação, ou o quarto capítulo, substituiu a concentração por uma dispersão que só pode ser compreendida a partir dos resultados da primeira metade, que formam uma espécie de grade - coordenadas sobre as quais podemos dispor os autores da segunda. Rohmer, Rivette, Astruc e Mourlet foram assim vistos como acréscimos e ramificações do pensamento de Bazin, ao mesmo tempo em que constituem abordagens com objetos e temperamentos próprios; da mesma forma, Sitney, Brakhage, Snow e Kubelka foram considerados em relação a Frampton. Através dessas ramificações, vimos como alguns posicionamentos parecem delinear características mais complexas dentro de cada vertente, como o interesse constante dos autores realistas pela relação entre o controle do cineasta e a manifestação do acaso, como uma invasão do mundo na composição; ou o problema da expressão, que surge tanto no contexto da mise en scène de Astruc como na morfologia proposta por Sitney.

O objetivo central deste último capítulo foi a busca por uma área intermediária através das referências resultantes das comparações entre esses autores. Observamos, por um lado, quais questões pareciam se cristalizar ao redor de cada autor, e em que sentido elas pareciam ligadas às especulações iniciais de Bazin e Frampton; e, por outro, 
como as formações dos dois "hemisférios" poderiam ser comparadas - como poderíamos nos localizar em suas dependências, identificando as áreas mais e menos próximas dos pólos, e finalmente uma tentativa de conceber a "linha intermediária" dessa representação. Partindo da polarização inicial, o reconhecimento de uma área onde as características dos pólos são equilibradas ou mesmo anuladas traria a ambiguidade que parece inerente num diálogo desse tipo. O problema com o qual toda a dissertação se confronta não é o da diferenciação, mas o da separação estrita, e do isolamento de gêneros de filmes e de terminologias: o que é tentado com a metáfora do globo é justamente a investigação dos caminhos pelos quais o cinema "narrativo" e o cinema "experimental", por exemplo, ou a crítica francesa e a crítica americana, podem entrar em diálogo, e reconhecer, nas duas direções, a marca de uma unidade que inclui ambas não como absolutas, mas relativas a esta e outras divisões. Isso se manifesta não apenas como uma intuição geral, mas mesmo como um princípio de definição, na possibilidade de conhecimento comparativo, na noção de que um filme pode ser compreendido mais integralmente se soubermos não apenas o que ele é, mas também o que ele não é. Figura e fundo seriam assim mutuamente delineados e iluminados.

Scott MacDonald, num artigo que critica os aspectos negativos de um cenário que isola as diferentes tendências em vez de integrá-las, comenta essa aspiração:

Devemos parar de categorizar filmes com base em uma retórica simplista e um desejo de simplificar a história do cinema. Sem dúvida é mais fácil escrever livros ou ministrar cursos sobre a história do cinema, ou fazer declarações sobre "os 10 melhores filmes do ano", quando o número e a variedade dos filmes envolvidos são pequenos. Mas imagine um crítico literário ou um professor de literatura que escreva um livro ou ministre um curso chamado A História da Literatura, e se recuse a incluir romances sob o argumento de que criam ilusões que leitores descerebrados aceitam como reais, ou se recuse a incluir poesia americana do século XX sob o argumento de que se preocupa mais com a arte literária, em vez de problemas da vida real! Ainda estamos no início da história do cinema, mas o mundo do cinema já cresceu muito além de tais generalizações. É hora de vermos críticos e professores de cinema com honestidade e humildade suficientes para reconhecer que a arte que eles amam é maior do que eles podem conter, e com a resistência para ajudar a desenvolver uma atmosfera onde aqueles interessados em cinema tenham a oportunidade de 
investigar os exemplos mais interessantes e desafiadores de todo tipo de cinema. ${ }^{303}$

A amplitude desse cenário exige que cada abordagem seja mais como uma contribuição ao empreendimento geral do que uma tentativa de resolução final dos problemas. A comparação dos pressupostos e dos resultados fílmicos deve ser constante, e o que uma abordagem evita deve ser considerado por uma abordagem seguinte. Por isso não é apenas desejável como fundamental que a devida importância seja dada ao que se encontra fora das dependências da pesquisa. Por um lado, o que parece implicado em seus resultados - como, por exemplo, a exploração direta das categorias do espaço e do tempo nos diferentes gêneros e cineastas - e, por outro lado, o que foi visto desde o início como um "desvio de rota" - a exclusão do vídeo, por exemplo, ou mesmo a ausência de nomes como Jean-Luc Godard ${ }^{304}$ e Christian Metz M5 $^{305}$ entre os cineastas e autores analisados.

O caráter de incerteza ou de incompletude talvez seja inevitável em qualquer tentativa particular desta ordem. Mas a partir das diretrizes aqui estabelecidas, podemos talvez apontar dois ideais, dois mitos como aqueles apontados por Bazin e Frampton, que serviriam como guias ou pelo menos descrições aproximadas de nossos pressupostos, e mesmo de nossos objetivos.

$\mathrm{O}$ primeiro seria o mito da exaustão arquimédica. $\mathrm{O}$ método da exaustão de Arquimedes se propõe a encontrar a área de um círculo através da aproximação com

${ }^{303}$ Scott MacDonald, "Against False Distinctions", in Film Quarterly, vol. 35, n 1, outono de 1981, p. 60

${ }^{304}$ A trajetória de Godard é única no sentido em que ele realizou a passagem entre alguns dos "continentes", e contribuiu consideravelmente em todos eles. Tendo começado nos anos 50 como um dos protegidos de Bazin nos Cahiers, ele atravessa a década de 60 como um dos principais nomes da Nouvelle Vague, até que se afasta de alguns dos preceitos do "movimento" na fundação do Grupo Dziga Vertov; mais tarde, flerta com a televisão e finalmente adota o vídeo como instrumento e o ensaio como parte central de seu método. A variedade de sua filmografia e o próprio volume de seus escritos fazem com que ele seja um nome sem dúvida importante nas discussões aqui consideradas. Esta é também a razão pela qual Godard não foi abordado: essa complexidade seria provavelmente mais prejudicada num tratamento breve.

${ }^{305}$ Os estudos de Christian Metz sobre a significação do cinema, e as relações entre o cinema e a linguagem, podem constituir um ponto de ligação entre a concepção de Bazin (que é a considerada por Metz, em grande parte de seus escritos) e a de Frampton, em sua filiação a Eisenstein e Vertov. O fator de peso na rejeição de Metz como referência para a pesquisa foi a natureza de seus conflitos dentro do próprio "hemisfério realista". Assim como no caso de Godard, o devido aprofundamento não poderia ser feito nos limites da dissertação. Andrew comenta como a proposta de Metz se coloca como uma reorientação das preocupações de Mitry (que por sua vez já buscava reelaborar o pensamento de Bazin e dos primeiros teóricos). Cf. Andrew, As Principais Teorias de Cinema, op. cit., pp. 170-173. 
outras figuras: se inscrevemos um quadrado no interior do círculo, temos determinada proximidade; se inscrevemos um hexágono, temos uma proximidade maior; se inscrevemos um octógono, uma proximidade ainda maior. Quanto maior o número de lados do polígono inscrito, mais nos aproximamos da área do círculo. A aproximação absoluta é, obviamente, impossível. Esse é o caráter do método, e o que parecemos encontrar numa tentativa de descrever o campo do cinema a partir de etapas finitas, deduzidas e intuídas a partir de exemplos concretos, textuais ou fílmicos. Quanto mais perspectivas diferentes considerarmos, e quanto mais conseguirmos integrar essas diferenças, mais próximos estaremos de uma descrição global do cinema.

Um segundo mito seria o da transcendência pela conjunção de opostos. A concepção de uma linha imaginária que separaria os dois hemisférios, e na qual encontraríamos a medida exata dessa divisão, pressupõe que essa divisão em pólos é "natural", e que o movimento do globo ocorre ao redor do eixo formado por eles; pressupõe também que há uma espécie de identidade subjacente entre os pólos, como entre luz e sombra, como se cada um deles fosse um lado diferente da mesma moeda. E assim como todas as cores existem entre a luz e a sombra, e todos os sons existem entre o silencio e o ruído branco, todos os filmes, e todas as concepções de cinema, todas as estéticas particulares, existiriam em algum ponto entre os dois pólos. 


\section{Referências bibliográficas}

ADAIR, Gilbert; ROSENBAUM, Jonathan; SEDOSFKY, Lauren. "Phantom Interviewers over Rivette”, in Film Comment, vol. 10, n 5, set/out de 1974.

ADRIANO, Carlos; VOROBOW, Bernardo. Peter Kubelka: A Essência do Cinema. São Paulo: Babushka, 2002.

ANDREW, Dudley. André Bazin. Nova York: Oxford University Press, 2013. . As Principais Teorias do Cinema. Rio de Janeiro: Jorge Zahar, 2002. . Concepts in Film Theory. Nova York: Oxford University Press, 1984. What Cinema Is: Bazin's Quest and its Charge. Oxford: Wiley-Blackwell,

2010.

ANDREW, Dudley; JOUBERT-LAURENCIN, Hervé (ed.). Opening Bazin. Nova York: Oxford University Press, 2011.

ARNHEIM, Rudolf. Film as Art. Berkeley: University of California Press, 1957.

ASTRUC, Alexandre. "Da Imagem à Ideia", in FOCO - Revista de Cinema, Agosto/Setembro, 2013. Disponível em:

http://www.focorevistadecinema.com.br/FOCO4/imagemideia.htm. Acesso em Julho de 2014. . "Le feut et la glace”, in Cahiers du Cinéma, n 18, dezembro de 1952. . "Naissance d'une nouvelle avant-garde: la caméra-stylo", in L'écran français, $\mathrm{n}^{\circ}$ 144. março de 1948.

AUERBACH, Erich. Mimesis: The Representation of Reality in Western Literature. Nova York: Doubleday Anchor Books, 1957.

AUMONT, Jacques. As Teorias dos Cineastas. Campinas: Papirus, 2004. . O Cinema e a Encenação. Lisboa: Texto \& Grafia, 2006. 
O Olho Interminável. São Paulo: Cosac Naify, 2004.

AUMONT, Jacques; MARIE, Michel. Dicionário Teórico e Crítico de Cinema. Campinas: Papirus, 2001.

BACHELARD, Gaston. O Novo Espírito Científico. Rio de Janeiro: Tempo Brasileiro, 1968.

BALÁZS, Bela. Theory of the Film. Londres: Dennis Dobson, 1977.

BATTEUX, Charles. As Belas-Artes Reduzidas a um Mesmo Princípio. São Paulo: Humanitas, 2009.

BAZIN, André. O Que é o Cinema? São Paulo: Cosac Naify, 2014. . Orson Welles. Rio de Janeiro: Jorge Zahar, 1998.

BRAKHAGE, Stan. Metaphors on Vision. Nova York: Film Culture, 1963. . "The Silent Sound Sense", in Film Culture, no 21, verão de 1960.

BRESSON, Robert. Notas Sobre o Cinematógrafo. São Paulo: Iluminuras, 2005.

BROWNE, Nick (ed.). Cahiers du cinéma, Vol. III - 1969-1972: The Politics of Representation. Londres: Routledge, 1996.

BURCH, Noel. A Práxis do Cinema. Lisboa: Estampa, 1973.

CARDULLO, Bert (ed.). André Bazin and Italian Neorealism. Nova York: Continuum, 2011. (ed.). Bazin at Work: Major Essays \& Reviews from the Forties \& Fifties. Nova York: Routledge, 1997. . In Search of Cinema. Montreal: McGill-Queen's University Press, 2004.

CARROLL, Noel. Engaging the Moving Image. New Haven / Londres: Yale University Press, 2003. 
"Philosophizing through the Moving Image: The Case of Serene

Velocity", in The Journal of Aesthetics and Art Criticism, vol. 64, $\mathrm{n}^{\circ}$ 1, inverno de 2006.

. Mystifying Movies. Nova York: Columbia University Press, 1988.

Theorizing the Moving Image. Nova York: Cambridge University Press,

1996.

CHION, Michel. Audio-Vision. Nova York: Columbia University Press, 1994.

DOUCHET, Jean. "Venise 61", in Cahiers du Cinéma, n 124, outubro de 1961.

DUSINBERRE, Deke; CHRISTIE, Ian. "Episodes from a Lost History of Movie Serialism”, in Film Studies, n 4, 2004.

EISENSTEIN, Sergei. A Forma do Filme. Rio de Janeiro: Jorge Zahar, 2002. . O Sentido do Filme. Rio de Janeiro: Jorge Zahar, 2002. . The Psychology of Composition. Londres: Methuen, 1988.

FRAMPTON, Hollis. Circles of Confusion: Film/Photography/Video Texts 1968-1980. Rochester: Visual Studies Workshop Press, 1983.

FRYE, Northrop. Anatomy of Criticism. Nova Jersey: Princeton University Press, 1957.

GALLAGHER, Tag. "Roberto Rossellini and Historical Neorealism", in Artforum, $\mathrm{n}^{\circ}$ 10, verão de 1975.

GEHR, Ernie. "Program notes by Ernie Gehr", in Film Culture, no 53-55, primavera de 1972.

GIDAL, Peter. Materialist Film. Londres: Routledge, 1989. (ed.). Structural Film Anthology. Londres: British Film Institute, 1978.

GOMBRICH, Ernst. Arte e Ilusão. São Paulo: Martins Fontes, 2007.

GOODMAN, Nelson. Languages of Art. Indianapolis: Hackett, 1976. 
GRAY, Hugh (ed.). André Bazin - What is Cinema? Vol. I. Londres: University of California Press, 2005.

(ed.). André Bazin - What is Cinema? Vol. II. Londres: University of California Press, 2005.

GREENE, William Chase (ed). The Dialogues of Plato. Nova York: Oxford University Press, 1927.

GRIFFITHS, Paul. A Música Moderna. Rio de Janeiro: Jorge Zahar, 1987.

GUINSBURG, Jacó (org.). O Classicismo. São Paulo: Perspectiva, 1999.

GUNNING, Tom. The Films of Fritz Lang: Allegories of Vision and Modernity. Londres: British Film Institute, 2000.

HAMMERMEISTER, Kai. The German Aesthetic Tradition. Cambridge University Press, 2002.

HENDERSON, Brian. "Bazin Defended against His Devotees", in Film Quarterly, vol. 32, no 4, verão de 1979.

"The Structure of Bazin's Thought" in Film Quarterly, vol. 25, n 4, verão de 1972.

. "Two Types of Film Theory", in Film Quarterly, vol. 24, n 3, primavera de 1971.

HILDEBRAND, Adolf. The Problem of Form in Painting and Sculpture. Nova York:

G.E. Stechert \& Co., 1907.

HILlIER, Jim (ed.). Cahiers du Cinéma, Vol. I - The 1950s: Neo-Realism, Hollywood, New Wave. Harvard University Press, 1985.

(ed.). Cahiers du Cinéma, Vol. II - 1960-1968: New Wave, New Cinema, Reevaluating Hollywood. Harvard University Press, 1986. 
JENKINS, Bruce (ed.). On the Camera Arts and Consecutive Matters: The Writings of Hollis Frampton. Cambridge / Londres: The MIT Press, 2009.

KANDINSKY, Wassily. Point and Line to Plane. Nova York: Dover, 1979.

KATERJI, Antoine. "Bazin, Mourlet: Convergence et Oppositions", in MOURLET, Michel. L'écran éblouissant. Paris: Presses Universitaires de France, 2011.

KELLER, Sarah; PAUL, Jason N. (ed.). Jean Epstein: Critical Essays and Translations. Amsterdam University Press, 2012.

KENNER, Hugh. Flaubert, Joyce, Beckett: The Stoic Comedians. Toronto: Beacon Press, 1962.

. Mazes. São Francisco: North Point, 1989.

. The Counterfeiters. Londres: Dakley Archive Press, 2005.

The Pound Era. Berkeley: University of California Press, 1973.

KOELLREUTTER, H.J. Introdução à Estética e à Composição Musical. Porto Alegre: Movimento, 1987.

KRACAUER, Siegfried. Theory of Film: The Redemption of Physical Reality. Nova York: Oxford University Press, 1960.

KRAMER, Jonathan. The Time of Music. Nova York: Schirmer, 1988.

KRAUSS, Rosalind; MICHELSON, Annette (ed.). October, $\mathrm{n}^{\mathrm{o}} 32$ - A Hollis Frampton Special Issue, primavera de 1985.

KRISTELLER, Paul Oskar. "The Modern System of the Arts", in Renaissance Thought and the Arts. Princeton University Press, 1980.

LEGGE, Elizabeth. Wavelength. Cambridge: The MIT Press, 2009.

LE GRICE, Malcolm. Abstract Film and Beyond. Cambridge: The MIT Press, 1978.

LESSING, G.E. Laocoon. Boston: Roberts Brothers, 1887. 
LEVACO, Ronald (ed.). Kuleshov on Film. Berkeley / Los Angeles: University of California Press, 1974.

LICHTENSTEIN, Jacqueline. A Cor Eloquente. São Paulo: Editora Siciliano, 1994.

LINDSAY, Vachel. The Art of the Moving Picture. Nova York: Modern Library, 2000.

LIPPMAN, Edward A. A History of Western Musical Aesthetics. Lincoln e Londres: University of Nebraska Press, 1992.

. The Philosophy and Aesthetics of Music. University of Nebraska Press, 1999.

LOOMIS, Louise Ropes (ed.). Aristotle - On Man in the Universe. Nova York: Classics Club, 1943.

MacCABE, Colin. Godard: A Portrait of the Artist at Seventy. Londres: Bloomsbury, 2003.

MACHADO, Arlindo. Pré-cinemas e Pós-cinemas. Campinas: Papirus, 1997.

MacDONALD, Scott. A Critical Cinema. Berkeley: University of California Press, 1988.

. A Critical Cinema 5. Berkeley / Los Angeles: University of California Press, 2006.

. "Peter Hutton: The Filmmaker as Luminist", in Chicago Review, vol. 47, $\mathrm{n}^{\circ} 3$, outono de 2001.

MELLENCAMP, Patricia; ROSEN, Philip (ed.). Cinema Histories, Cinema Practices. University of Michigan, 1984.

MENDELSSOHN, Moses. Philosophical Writings. Cambridge University Press, 1997.

MICHELSON, Annette. "Bodies in Space: Film as Carnal Knowledge", in Artforum, vol. $7, \mathrm{n}^{\circ}$ 6, fevereiro de 1969.

MILNE, Tom (ed.). Godard on Godard. Nova York: Da Capo, 1985. 
MITRY, Jean. The Aesthetics and Psychology of Cinema. Bloomington: Indiana University Press, 2000.

MOURLET, Michel. “Apologie de la violence”, in Cahiers du Cinéma, $\mathrm{n}^{\circ}$ 107, maio de 1960.

. "Beauté de la connaissance", in Cahiers du Cinéma, no 111, setembro de 1960.

. "Rohmer ou La mise en scène du langage", in Sur un art ignoré ou La mise en scène comme langage. Paris: Ramsey, 2008.

. "Sur un art ignoré”, in Cahiers du Cinéma, n 98, agosto de 1959.

. "Trajectoire de Fritz Lang", in Cahiers du Cinéma, n 99, setembro de

1959.

. "Une lucidité virile", in Présence du Cinéma, no 13, maio de 1962.

O'BRIAN, John (ed.). Clement Greenberg - The Collected Essays and Criticism, Vol.

1: Perceptions and Judgements, 1939-1944. Chicago e Londres: The University of Chicago Press, 1988.

(ed.). Clement Greenberg - The Collected Essays and Criticism, Vol. 4:

Modernism with a Vengeance, 1957-1969. Chicago e Londres: The University of Chicago Press, 1988.

OLIVEIRA JR., Luiz Carlos. A mise en scène no cinema: Do clássico ao cinema de fluxo. Campinas: Papirus, 2013.

PANOFSKY, Erwin. Perspective as Symbolic Form. Nova York: Zone Books, 1991.

POUND, Ezra. ABC da Literatura. São Paulo: Cultrix, 1967.

RIMMER, Scott. The Symbolic Form of Architecture. Virginia: Faculty of the Virginia Polytechnic Institute and State University, 1997.

ROBBE-GRILLET, Alain. Por um Novo Romance. São Paulo: Nova Crítica, 1969. 
ROHMER, Éric. L'organisation de l'space dans le Faust de Murnau. Paris: UGE, 1977. . The Taste for Beauty. Cambridge University Press, 1989.

ROSA, Carlos Adriano J. de. O mutoscópio explica a invenção do pensamento de Santos Dumont: cinema experimental de reapropriação de arquivo em forma digital. 2008. 384 f. Dissertação (Doutorado em Ciências da Comunicação) - Orientador: Prof. Dr. Ismail Norberto Xavier - Escola de Comunicações e Artes, Universidade de São Paulo, 2008.

ROSENBAUM, Jonathan (ed.). Rivette - Texts and Interviews. Londres: British Film Institute, 1977.

SNOW, Michael. "Notes for Rameau's Nephew”, in October, n 4, outono de 1977. . "On 'La Région Centrale”, in Film Culture, n 52, primavera de 1971.

SITNEY, P. Adams. Eyes Upside Down: Visionary Filmmakers and the Heritage of Emerson. Oxford University Press, 2008.

(ed.). Film Culture Reader. Nova York: Cooper Square, 2000. . "Kubelka Concrete", in Film Culture, no 34, outono de 1964. (ed.). The Avant Garde Film: A Reader of Theory and Criticism. Nova York: Anthology Film Archives, 1987.

(ed.). The Essential Cinema: Essays on Films in the Collection of Anthology Film Archives. Nova York: Anthology Film Archives, 1989. . "The Idea of Abstraction", in Film Culture, no 63-64, 1977. . "The Idea of Morphology", in Film Culture, n 53-55, primavera de 1972. . Visionary Film. Nova York: Oxford University Press, 2002.

STAM, Robert. Introdução à Teoria do Cinema. Campinas: Papirus, 2003.

STEINHOFF, Eirik (ed.), Stan Brakhage: Correspondences. Chicago: Chicago Review, 2001. 
TRUFFAUT, François (ed.). Jean Renoir by André Bazin. Londres e Nova York: Howard \& Wyndham, 1974.

REICH, Willi (ed.). Anton Webern - The Path to New Music. Pennsylvania: Theodore Presser, Co., 1963.

STIMPSON, Brian (ed.). Paul Valéry - Cahiers/Notebooks 2. Frankfurt: Peter Lang, 2000.

WILSON, David (ed.). Cahiers du Cinéma, Vol. IV - 1973-1978: History, Ideology, Cultural Struggle. Londres: Routledge, 2000.

WÖLFFLIN, Heinrich. Principles of Art History. Nova York: Dover Publications, 1950. XAVIER, Ismail (org.). A Experiência do Cinema. São Paulo: Graal, 2003. O Discurso Cinematográfico: A opacidade e a transparência. Rio de Janeiro: Paz e Terra, 1977. . Sétima Arte: Um Culto Moderno. São Paulo: Perspectiva, 1978. 


\section{Filmografia principal ${ }^{*}$}

Kenneth Anger:

Fireworks (EUA, 1947) - Disponível em:

https://www.youtube.com/watch?v=_qxDcpLylSk

Alexandre Astruc:

Le Puits et le Pendule (França, 1964)

Evariste Galois (França, 1965)

Stan Brakhage:

Dog Star Man (EUA, 1962-64) - Disponível em:

https://www.youtube.com/watch?v=NAoTHILzheo

Commingled Containers (EUA, 1994) - Disponível em:

https://www.youtube.com/watch?v=ap-v_Sk20Jg

Robert Bresson:

Diário de um Pároco de Aldeia (Journal d'un curé de campagne, França, 1951)

Um Condenado à Morte Escapou (Une condamné à mort s'est échappé, França, 1956)

Luis Buñuel:

Um Cão Andaluz (Un chien andalou, França, 1928)

Maya Deren:

Meshes of the Afternoon (EUA, 1943) - Disponível em:

https://www.youtube.com/watch?v=_mm3lEUThPo

Hollis Frampton:

Zorns Lemma (EUA, 1970) - Disponível em:

https://www.youtube.com/watch?v=ec2-GZRYGd8

Nostalgia (EUA, 1971) - Disponível em:

https://www.youtube.com/playlist?list=PL313CFE2D67C39FEB

Critical Mass (EUA, 1971) - Disponível em:

https://www.youtube.com/playlist?list=PL28C976FB759B15CD

Poetic Justice (EUA, 1972) - Disponível em:

https://www.youtube.com/watch?v=-rIXtiz_yhQ

Ernie Gehr:

Serene Velocity (EUA, 1970) - Excerto disponível em:

https://www.youtube.com/watch?v=KYfNFtLSuv4

Eureka (EUA, 1974) - Disponível em:

https://www.youtube.com/watch?v=WGNq319BLH8

\footnotetext{
* Todos os links para os filmes foram acessados em 22 de Julho de 2014.
} 
Peter Hutton:

Time and Tide (EUA, 2000) - Disponível em:

https://www.youtube.com/watch?v=AKzEX_IJX4Q

Isidore Isou:

Traité de bave et d'eternité (França, 1951) - Disponível em:

https://www.youtube.com/playlist?list=PL4F18045AD4A9B07B

Ken Jacobs:

Tom, Tom, the Piper's Son (EUA, 1969) - Excerto disponível em: https://www.youtube.com/watch?v=wO0zVHy0OFA

Peter Kubelka:

Adebar (Áustria, 1957) - Disponível em: https://www.youtube.com/watch?v=1S0aoQQxzwk

Schwechater (Áustria, 1958) - Disponível em:

https://www.youtube.com/watch?v=cy78LNZFMIE

Arnulf Rainer (Áustria, 1960) - Disponível em:

https://www.youtube.com/watch?v=iw1DVtFAz64

Unsere Afrikareise (Áustria, 1966) - Disponível em:

http://www.dailymotion.com/video/xo5z1_peter-kubelka_creation

Stanley Kubrick:

2001: Uma Odisséia no Espaço (2001: A Space Odyssey, EUA, 1968)

Fritz Lang:

Suplício de uma Alma (Beyond a Reasonable Doubt, EUA, 1956)

Joseph Losey:

The Big Night (EUA, 1951)

The Criminal (Reino Unido, 1960)

Auguste e Louis Lumière:

L'arrivée d'un train en gare de La Ciotat (França, 1895) - Disponível em:

https://www.youtube.com/watch?v=1dgLEDdFddk

Jean Renoir:

A Regra do Jogo (La Règle du jeu, França, 1939)

Alain Resnais:

Hiroshima Mon Amour (França, 1959)

Ano Passado em Marienbad (L'Année dernière à Marienbad, França, 1961)

Hans Richter:

Rhytmus 21 (Alemanha, 1921) - Disponível em:

https://www.youtube.com/watch?v=b972EQOOEoY 
Jacques Rivette:

A Religiosa (La religieuse, França, 1962)

Não Toque no Machado (Ne touchez pas la hache, 2007)

Éric Rohmer:

A Colecionadora (La collectioneuse, 1967)

Minha Noite Com Ela (Ma nuit chez Maud, 1969)

Roberto Rossellini:

Stromboli (Itália/EUA, 1950)

Viagem à Itália (Viaggio in Italia, Itália, 1954)

Beaubourg, centre d'art et de culture Georges Pompidou (França, 1977)

Michael Snow:

Wavelength (Canadá/EUA, 1967) - Disponível em:

https://www.youtube.com/watch?v=aBOzOVLxbCE

Back and Forth (Canadá, 1969)

One Second in Montreal (Canadá, 1969)

La Région Centrale (Canadá, 1971) - Excerto disponível em:

https://www.youtube.com/watch?v=uYr_SvIKKuI

Rameau's Nephew (Canadá, 1974) - Excerto disponível em:

https://www.youtube.com/watch? $=\mathrm{J} 1 \mathrm{vQfnqtJKU}$

So Is This (Canadá, 1983) - Disponível em:

https://www.youtube.com/playlist?list=PL928D3FC0159E4820

Orson Welles:

Cidadão Kane (Citizen Kane, EUA, 1941)

Soberba (The Magnificent Ambersons, EUA, 1942) 
ANEXOS 


\section{O mito do cinema total ${ }^{306}$}

Paradoxalmente, ${ }^{307}$ a impressão que se tem à leitura do admirável livro de Georges Sadoul sobre as origens do cinema, ${ }^{308}$ apesar do ponto de vista marxista do autor, é a de uma inversão das relações entre a evolução econômica e técnica e a imaginação dos pesquisadores. Parece que tudo se passa como se devêssemos inverter a causalidade histórica que vai da infraestrutura econômica às superestruturas ideológicas e considerar as descobertas técnicas fundamentais como acidentes providenciais e favoráveis, porém essencialmente secundários, em relação à ideia preliminar dos inventores. O cinema é um fenômeno idealista. A ideia que os homens fizeram dele já estava armada em seu cérebro, como no céu platônico, e o que impressiona, acima de tudo, é a resistência tenaz da matéria à ideia, mais do que as sugestões da técnica à imaginação do pesquisador.

Aliás, o cinema não deve quase nada ao espírito científico. Seus pais não são de modo algum eruditos (com exceção de Marey, mas é significativo que este só se interessasse pela análise do movimento e não pelo processo inverso, que permitia recompô-lo). O próprio Edison não passa de um bricoleur genial, um monstro do concurso Lépine. Niépce, Muybridge, Leroy, Joly, Demenÿ, o próprio Louis Lumière são monomaníacos, desvairados, bricoleurs ou, no melhor dos casos, industriais engenhosos. Quanto ao maravilhoso, sublime E. Reynaud, quem não vê que seus desenhos animados são o resultado de uma perseguição obstinada de uma ideia fixa? Explicaríamos bem mal a descoberta do cinema partindo das descobertas técnicas que o permitiram. Ao contrário, uma realização aproximativa e complicada da ideia precede quase sempre a descoberta industrial, única que pode tornar viável sua aplicação prática. Assim, se hoje nos parece evidente que o cinema, em sua forma mais elementar, precisava utilizar um suporte transparente, flexível e resistente, e uma emulsão sensível seca, capaz de fixar uma imagem instantânea (e todo o resto sendo apenas uma questão de ajustes mecânicos bem menos complicados que um relógio do século XVIII), percebemos que todas as etapas decisivas da invenção do cinema foram transpostas

\footnotetext{
306 André Bazin, O Que é o Cinema? (São Paulo: Cosac Naify, 2014), pp. 35-40. As notas seguintes são do próprio texto de Bazin.

${ }^{307}$ Texto publicado originalmente em Critique, n. 6, Nov. 1946, pp. 552-57.

${ }^{308}$ L'Invention du cinema (1832-1897), v. I. Paris: Denoël, 1946.
} 
antes de essas condições serem preenchidas. Muybridge, graças à dispendiosa fantasia de um amador de cavalos, consegue realizar, em 1877 e 1880, um imenso complexo que lhe permitirá fazer, com imagens de um cavalo galopando, a primeira série cinematográfica. Ora, para obter esse resultado, ele precisou se contentar com o colódio úmido sobre placa de vidro (ou seja, com apenas uma das três condições essenciais: instantaneidade, emulsão seca e suporte flexível). Depois da descoberta, em 1880, da gelatina-brometo de prata, mas antes do aparecimento no comércio das primeiras fitas de celuloide, Marey constrói com seu fuzil fotográfico uma verdadeira câmera para placas de vidro. Enfim, mesmo depois do surgimento comercial do filme em celuloide, o próprio Lumière tentará primeiro usar filme de papel.

E só consideramos aqui a forma definitiva e completa do cinema fotográfico. A síntese de movimentos elementares cientificamente estudada pela primeira vez por Plateau não precisava esperar pelo desenvolvimento industrial e econômico do século XIX. Como Sadoul acertadamente observa, nada se opunha, desde a Antiguidade, à realização do fenacistiscópio ou do zootrópio. É verdade que, aqui, os trabalhos de um autêntico erudito, Plateau, estão na origem das várias invenções mecânicas que permitiram o uso popular de sua descoberta. Mas se, para o cinema fotográfico, temos motivos para ficar admirados com o fato de a descoberta preceder de algum modo as condições técnicas indispensáveis para sua realização, seria preciso explicar aqui, em contrapartida, como, com todas as condições já reunidas havia muito tempo (a persistência retiniana era um fenômeno conhecido de longa data), a invenção tenha levado tanto tempo para surgir. Convém notar que, sem qualquer relação cientificamente necessária, os trabalhos de Plateau são quase contemporâneos aos de Nicéphore Niépce, como se a atenção dos pesquisadores tivesse esperado, durante séculos, para se interessar pela síntese do movimento que a química independentemente da ótica - se interessasse, por seu lado, pela fixação automática da imagem. ${ }^{309}$ Enfatizo que tal coincidência histórica não parece poder, de modo algum,

\footnotetext{
${ }^{309}$ Os afrescos ou os baixos-relevos egípcios revelam mais uma vontade de análise do movimento do que de sua síntese. Quanto aos autômatos do século XVIII, eles estão para o cinema como a pintura para a fotografia. Seja lá como for, e mesmo se os autômatos prefiguram, desde Descartes e Pascal, as máquinas do século XIX, não é diferente da maneira como os trompe l'oeil pictóricos atestam um gosto exacerbado pela semelhança. A técnica do trompe l'oeil, entretanto, não fez avançar a ótica e a química fotográfica; ela se limitava, se ouso dizer, a imitá-las por antecipação.

Além disso, como a palavra indica, a estética do trompe l'oeil no século XVIII reside mais na ilusão do que no realismo, isto é, mais na mentira do que na verdade. Uma estátua pintada sobre uma parede deve parecer estar assentada sobre uma base no espaço. De certo modo, foia isso também que o
} 
ser explicada pela evolução científica econômica ou industrial. O cinema fotográfico poderia perfeitamente ter se intrometido, por volta de 1890, num fenacistiscópio imaginado desde o século XVI. O atraso na invenção deste é tão perturbador quanto a existência dos precursores daquele.

Mas, se examinarmos minuciosamente seus trabalhos e o sentido de sua pesquisa, tal como transparece nos próprios aparelhos e, de modo mais indiscutível, nos escritos e comentários que os acompanham, constatamos que esses precursores eram antes de tudo profetas. Queimando etapas, sendo que a primeira delas já lhes era materialmente intransponível, a maioria deles vai visar diretamente o mais alto. Sua imaginação identifica a ideia cinematográfica com uma representação total e integral da realidade; ela tem em vista, de saída, a restituição de uma ilusão perfeita do mundo exterior, com o som, a cor e o relevo.

Quanto a este último, um historiador do cinema, P. Potoniée, pôde inclusive sustentar que:

não foi a descoberta da fotografia e sim a da estereoscopia (introduzida no comércio pouco antes das primeiras experiências da fotografia animada, em 1851) que abriu os olhos dos pesquisadores. Percebendo os personagens imóveis no espaço, os fotógrafos se deram conta de que lhes faltava movimento para ser a imagem da vida e a cópia fiel da natureza.

De qualquer forma, qualquer inventor procura unir o som e o relevo à animação da imagem. Seja Edison, cujo cinetoscópio individual devia ser acoplado a um fonógrafo com caixas acústicas, ou Demenÿ e seus retratos falantes, ou até mesmo Nadar que, pouco tempo antes de realizar a primeira reportagem fotográfica sobre Chevreul, escreveu: "Meu sonho é ver a fotografia registrar atitudes e mudanças de fisionomia de um orador à medida que o fonógrafo registra suas palavras" (fevereiro de 1887). A cor ainda não é evocada porque as primeiras experiências de tricomia serão mais tardias. Mas E. Reynaud já pintava suas figurinhas havia muito tempo e os primeiros filmes de Méliès são coloridos à mão. São muitos os textos, mais ou menos delirantes; em que os inventores evocam nada menos do que esse cinema integral que dá a completa ilusão da

cinema principiante visou, mas essa função de embuste logo cede lugar a um realismo ontogenético (cf. "Ontologia da imagem fotográfica", supra, pp. 27-34). 
vida e do qual ainda hoje estamos longe; conhecemos o trecho de A Eva futura [L'Ève future], no qual Villiers de l'Isle-Adam, dois anos antes de Edison começar suas primeiras pesquisas sobre a fotografia animada, lhe atribui esta fantástica realização:

[...] a visão, carne transparente milagrosamente fotocromada, dançava, em trajes de lantejoulas, uma espécie de dança mexicana popular. Os movimentos mostravam-se com o próprio matiz da vida, graças ao procedimento de fotografia sucessiva que pode captar dez minutos dos movimentos sobre lentes microscópicas, refletidos em seguida por um potente lampascópio... Subitamente uma voz homogênea e como que compassada, uma voz tola e dura se fez ouvir. A dançarina cantou o alza e o olé de seu fandango.

O mito diretor da invenção do cinema é, portanto, a realização daquele que domina confusamente todas as técnicas de reprodução mecânica da realidade que apareceram no século XIX, da fotografia ao fonógrafo. É o mito do realismo integral, de uma recriação do mundo à sua imagem, uma imagem sobre a qual não pesaria a hipoteca da liberdade de interpretação do artista, nem a irreversibilidade do tempo. Se em sua origem o cinema não teve todos os atributos do cinema total de amanhã, foi, portanto, a contragosto e, unicamente, porque suas fadas madrinhas eram tecnicamente impotentes para dotá-lo de tais atributos, embora fosse o que desejassem.

Se as origens de uma arte deixam transparecer algo de sua essência, é válido considerar os cinemas mudo e falado como as etapas de um desenvolvimento técnico que realiza pouco a pouco o mito original dos pesquisadores. Compreende-se, nessa perspectiva, que seja absurdo considerar o cinema mudo como uma espécie de perfeição primitiva, da qual o realismo do som e da cor se afastaria cada vez mais. A primazia da imagem é histórica e tecnicamente acidental, o saudosismo de alguns pelo mutismo da tela não remonta o bastante à infância da sétima arte; os verdadeiros primitivos do cinema, aqueles que só existiram na imaginação de algumas dezenas de homens do século XIX, pensam na imitação integral da natureza. Logo, todos os aperfeiçoamentos acrescentados pelo cinema só podem, paradoxalmente, aproximá-lo de suas origens. O cinema ainda não foi inventado!

Seria, portanto, uma inversão, ao menos do ponto de vista psicológico, da ordem concreta da causalidade, situar as descobertas científicas ou as técnicas industriais, que irão tomar um lugar tão grande no desenvolvimento do cinema, no princípio de sua 
invenção. Os que menos confiaram no futuro do cinema como arte e mesmo como indústria foram, precisamente, os dois industriais, Edison e Lumière. Edison contentouse com seu cinetoscópio individual, e se Lumière recusou judiciosamente a Méliès a venda de sua patente, foi porque provavelmente pensava ter mais lucro se ele mesmo a explorasse, mas na verdade como um brinquedo, do qual mais dia menos dia o público se cansaria. Quanto aos verdadeiros eruditos, como Marey, só serviriam ao cinema incidentalmente, pois tinham outro objetivo preciso, que, quando atingido, os deixou satisfeitos. Os fanáticos, os maníacos, os pioneiros desinteressados, capazes, como Bernard Palissy, de queimar seus móveis para obter alguns segundos de imagens vacilantes, não são nem industriais nem eruditos, mas possuídos por sua própria imaginação. Se o cinema nasceu, isso se deve à convergência da obsessão deles; isto é, de um mito: o do cinema total. Assim ficam explicados tanto o atraso de Plateau em aplicar o princípio ótico da persistência retiniana quanto o constante progresso da síntese do movimento sobre o estado das técnicas fotográficas. O fato é que ambos estavam dominados pela imaginação do século. É claro que encontraríamos outros exemplos, na história das técnicas e das invenções, da convergência das pesquisas, mas é preciso distinguir aquelas que resultam precisamente da evolução científica e das necessidades industriais (ou militares) daquelas que, obviamente, as precedem. Desse modo, o velho mito de Ícaro precisou esperar o motor de explosão para descer do céu platônico. Ele existia, porém, na alma de cada homem desde que ele contemplou o pássaro. De certo modo, pode-se dizer o mesmo do mito do cinema, mas seus avatares até o século XIX têm apenas uma longínqua relação com aquele do qual hoje em dia participamos, e que foi o promotor do aparecimento das artes mecânicas, características do mundo contemporâneo. 


\section{Film in the House of the Word ${ }^{310}$}

In 1928, Sergei Eisenstein published a brief manifesto on film sound that has met with no direct critique or reply in more than half a century. ${ }^{311}$ In his statement, written within an euphoric moment of convergence between theory and practice that gave us October and The General Line, and suggested to him the grand project of an intellectual montage,' Eisenstein began an effort that precipitated in a group of empty centers and their satellite notes and essays; the hypothetical cinematic 'realizations' of three written texts... An American Tragedy, Ulysses, and Capital. Eisenstein himself, under the extreme pressures of the Stalinist 'restoration,' largely abandoned his research into intellectual montage for extended meditations on synaesthesia, the microstructure of the frame, and the architectonics of film narrative, in a resurrection of the quest for a fusion of the arts; the man who directed a production of The Valkyrie in Moscow must have seen, in the musical drama of Wagner, a prefiguration of some of film's boldest ambitions. These ambitions still obtain; that research, advanced by Vertov, has never entirely languished.

"The dream of a sound film has come true... The whole world is talking about the silent thing that has learned to talk." Eisenstein awakened to the factualization of desire with surprise ambivalence, as if discovering the Silent Thing to have been carved by Pygmalion - for film, perennially associated with music, had never been generically silent. It had been mute, once an apprentice mime in a precinematic (and prelinguistic) theater, to whose construction a sound-on-film technology was as vital as cinematography itself.

It was not simply sound, then, that threatened to destroy all the 'present formal achievements' of montage, but the dubious gift of speech, the Prime Instance of Language, the linear decoding of the terrain of thought into a stream of utterance. Thus film, from its first word, was to be perceived in a double posture of defilement and

\footnotetext{
${ }^{310}$ Hollis Frampton, in Bruce Jenkins (ed.), On the Camera Arts and Consecutive Matters: The Writings of Hollis Frampton, pp. 166-170. Originalmente em October, $\mathrm{n}^{\circ}$ 17, verão de 1981. As notas seguintes são de Bruce Jenkins, editor da compilação.

311 The manifesto on the sound film, titled "Statement," was jointly issued by Eisenstein and the directors Vsevolod Pudovkin and Gregori Alexandrov in the Leningrand magazine Zhizn Iskusstva in 1928 and appeared in English translation in the New York Herald Tribune, the New York Times, and the London magazine Close Up in the same year. It was Frampton's belief that the statement represented Eisenstein's thinking and writing, despite the presence of the other signatories.
} 
fulfillment, and Eisenstein found himself present at a rite of passage; the end of the edenic childhood of montage was accompanied by a wistful vision of 'fading virginity and purity.'

The syndrome of logophobia has been pandemic throughout recent practice in the visual arts. "How many colours are there in a field of grass," Stan Brakhage asks in Metaphors On Vision, “for a crawling baby who has never heard of green?" We are prompted to enter into complicity with the author: the word is anaesthetic, truncating the report of an innocent sensorium, depriving thought of that direct Vision of a universe of ideal forms that would pierce, sweep away, the clutter of denatured simulacra created by language - and so the infant, traversing the fulsome excellence of a Garden that somehow exists without the intervention of the Word, must see an infinitude of colors.

Others reason that the crawling baby sees no 'colors' at all, since the notion of color is a complex abstraction, closely bound to language and culture (there are natural languages that make no distinction between 'green' and 'blue') that brackets a neurophysiological response to a portion of the electromagnetic spectrum. The field of grass is without form, and void.

During painting's culminating assault on illusion, in the 1950's and ' 60 's, one often heard the epithet 'literary' as a pejorative to work that retained vestiges of recognizable (and thereby nameable) pretext sufficient to the identification of an imbedding deep space - although the presence of the world as a graphic sign (in Robert Motherwell's Je t'aime paintings, for instance, or Frank Stella's Mary Lou series) was accepted with routine serenity. One heard Barnet Newman admonish Larry Poons when the younger painter had published, as a show poster, a photograph incorporating an assertive pun on his own name; ${ }^{312}$ saw Carl Andre in ardent moral outrage at the very mention of Magritte; witnessed the monolithic public silence of the generation of Abstract Expressionists.

The terms of indictment were clear: language was suspect as the defender of illusion, and both must be purged together, in the interest of a rematerialization of a tradition besieged by the superior illusions of photography. Only the poetics of the title escaped inquisition, for a time. If there is some final genetic bond between language and

312 The poster, depicting the artist with a pair of spoons placed like goggles over his eyes ("Poons/Spoons"), was based on a photograph that Frampton had made. 
illusion, then the atavistic persistence of illusion... fossil traces, upon the painterly surface, of thickets, vistas of torn gauze, spread hides, systems of tinted shadows, receding perspectives of arches... affirms, at last, the utter permeance of language.

Now we are not perfectly free to make language an agonist in a theater of desire which is itself defined by the limits of language. Every artistic dialogue that concludes in a decision to ostracize the word is disingenuous to the degree that it succeeds in concealing from itself its fear of the word - and the source of that fear: that language, in every culture, and before it may become an arena of discourse, is, above all, an expanding arena of power, claiming for itself and its wielders all that it can seize, and relinquishing nothing. In this regard, Eisenstein is characteristically abrupt, claiming for film, in accord with Lenin's own assessment of the Revolution's priorities, something of the power of language: "At present, the film, working with visual images, has a powerful effect on a person and has rightfully taken one of the first places among the arts."

Film, like all the arts, was to instruct, to move; its considerable privilege derived, ironically, from a double illiteracy: its diegesis was legible to a mass populace that could not read, and its formal strategies were largely illegible to a burgeoning elite that could. Eisenstein was at some pains to preserve film's claim to political efficiency: in the midst of the short text he paused to offer a gratuitous recantation for the 'formalist' errors of October, submitting that the advent of sound will spare the director from resorting to "fanciful montage structures, arousing the fearsome eventuality of meaningless and reactionary decadence." Invoking the power of language, he issued preliminary disclaimers for near occasions of sin not yet contemplated; in 1932, in $A$ Course in Treatment, he was to write of "wonderful sketches," never to be expanded, for montage structures that anticipate a much later historical moment in film, fanciful enough to normalize the "formalist jackstraws" of Man with a Movie Camera. ${ }^{313}$

Sound, we read, will ameliorate film's "imperfect method," improve its thermodynamic efficiency: what brings the menace of speech abolishes writing, and the mode of reading that accompanies it, eliding those discontinuities in an illusionist continuum introduced by the intrusion of the graphic intertitle. Parenthetically, as well, it will restore to equilibrium an imbalance in film's psychological distance from the

\footnotetext{
313 The reference is to Dziga Vertov's 1929 film, an urban portrait that combines nonfiction with such "jackstraws" as stop-motion, double explosure, slow motion, and other effects.
} 
spectator by obviating "certain inserted close-ups" that have played a mere "explanatory" role, "burdening" montage composition, decreasing its tempo. However, and above all, complete dissynchrony between sound and image is to be maintained (Eisenstein did not, for the moment, insist on more drastic disjunctions), since the permanent "adhesion" of sound to a given image, as of a name to its referent, increases that image's "inertia", and its independence of meaning.

Thus far, we find no single imperative that requires Eisenstein's logophobia. Bud suddenly (the adverb is peculiarly his own: an intertitle that announces the massacre on the Odessa Steps in Potemkin) one may recognize, within the diction of a text that adroitly warns us away from language, a crucial agenda: the preservation of a dim outline of what it is that he is so anxious to protect from language. One may imagine something whose parts are to be denied, and protected from, interdependence and mutual adhesion; it is not to be burdened, nor its inertia increased, nor its tempo retarded; it is to remain portable across cultural boundaries, and its elaboration and development are not to be impeded.

There are only two hypothetical symbolic systems whose formal descriptions meet such requirements. One is a universal natural language; the other is a perfect machine. As one reflects that the two are mutually congruent, one remembers that Eisenstein was at once a gifted linguist, an artist haunted by the claims of language and also, by training, an engineer. It seems possible to suggest that he glimpsed, however quickly, a project beyond the intellectual montage: the construction of a machine, very much like film, more efficient than language, that might, entering into direct competition with language, transcend its speed, abstraction, compactness, democracy, ambiguity, power... a project, moreover, whose ultimate promise was the construction of an external critique of language itself. If such a thing were to be, a consequent celestial mechanics of the intellect might picture a body called Language, and a body called Film, in symmetrical orbit about one another, in perpetual and dialectical motion.

It is natural that considerable libidinal energy should be expended to protest such fragile transitions in thought. The ritual gesture that wards off language also preserves language, as well as film, for a later moment of parity, of confrontation.

All of Eisenstein's bleakest predictions came true: the commercial success of the talkies polarized the development of a system of distribution that virtually guaranteed 
the stagnation of the sound track as an independent and coeval information channel sustaining the growth of a complex montage in consensual simultaneity.

Even if the requirements of Socialist Realism had not supervened, the vicissitude of specialism might well have prevented even Sergei Eisenstein, the director, from attempting the expected "first experimental work" with sound along the lines of "distinct non-synchronization" with images. Nevertheless, the work goes on, and filmmakers have responded, with increasing rigor, to the urgent contradictions he first expounded. Not through immediate design and cathexis, but by the way of an historical process of the exhaustion of its alternatives, the deferred dream of the sound film presents itself to be dreamed again.

A man condemned to death begged Alexander to pardon him, vowing, given a year's reprieve, that he would teach Bucephalus (who already spoke Bulgarian, Farsi and Greek) to sing. When his friends derided him for a fool who merely postponed the inevitable, he replied: "A year is a long time. The king may die; I may die. Or... who knows! ... maybe the horse will learn to sing!" 